\title{
Universiteit
}

Leiden

The Netherlands

\section{In the Land of the Chiefs : customary law, land conflicts, and the role of the state in Peri-Urban Ghana}

Ubink, Janine Marisca

\section{Citation}

Ubink, J. M. (2008). In the Land of the Chiefs : customary law, land conflicts, and the role of the state in Peri-Urban Ghana. Retrieved from https://hdl.handle.net/1887/21154

Version:

Not Applicable (or Unknown)

License:

Leiden University Non-exclusive license

Downloaded from: $\quad$ https://hdl.handle.net/1887/21154

Note: To cite this publication please use the final published version (if applicable). 


\section{LAW, GOVERNANCE, AND DEVELOPMENT DISSERTATIONS}

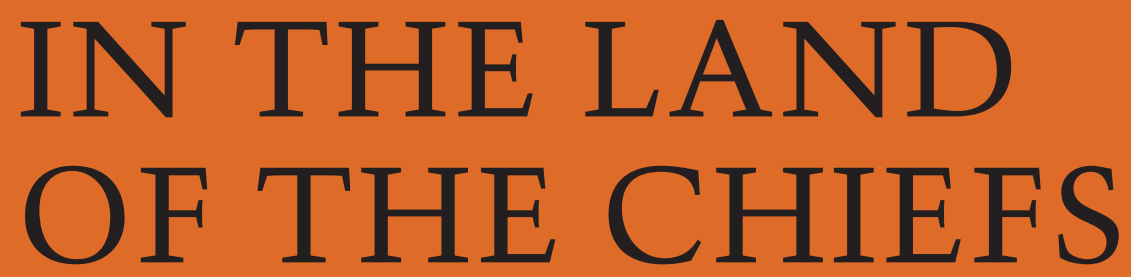

Customary Law, Land Conflicts,

and the Role of the State in Peri-Urban Ghana

JANINE M. UBINK 
In the Land of the Chiefs 


\section{Law, Governance, and Development}

Over a short period of time, the strengthening of law and governance has become a major focus for international development organizations, as well as for governments and organizations at the national level. These are now devoting a substantial portion of development funds into reform and capacity building programmes aimed at legal and administrative institutions in transitional and developing countries.

However, the 'building' of legal and governance systems is proving to be a dauntingly difficult and complex task and one in which the methods of approach are highly contested. It has been assumed that law and governance reform is a technical, managerial and financial matter, which allows for the export of laws and the transplantation of legal and administrative structures. The disappointing results of such reforms have illustrated, however, that not enough attention has been given to how laws, policies, institutions and stakeholders operate in reality, in their socio-political contexts. The uniqueness of individual countries, sectors and institutions is often insufficiently understood, and the actual experiences with the myriad of law and governance programmes and projects are not translated into knowledge on how law and governance reform promotes development.

In response, the Leiden University Press series on Law, Governance, and Development brings together an interdisciplinary body of work about the formation and functioning of systems of law and governance in developing countries, and about interventions to strengthen them. The series aims to engage academics, policy makers and practitioners at the national and international level, thus attempting to stimulate legal reform for development. 


\title{
In the Land of the Chiefs
}

\author{
Customary Law, Land Conflicts, and \\ the Role of the State in Peri-Urban Ghana
}

Janine Marisca Ubink 
The research this book is based on and its publications have been made possible by grants from the Netherlands Organisation for Scientific Research (NWO), the Leiden University Fund (LUF), the Adatrechtstichting, and Mordenate College.

Cover design: Studio Jan de Boer, Amsterdam

Layout: The DocWorkers, Almere

ISBN 978908728 O4I 3

NUR $764 / 820$

(C) Janine M. Ubink / Leiden University Press, 2008

All rights reserved. Without limiting the rights under copyright reserved above, no part of this book may be reproduced, stored in or introduced into a retrieval system, or transmitted, in any form or by any means (electronic, mechanical, photocopying, recording or otherwise) without the written permission of both the copyright owner and the author of the book. 


\section{Contents}

$\begin{array}{ll}\text { Acknowledgements } & 7\end{array}$

$\begin{array}{ll}\text { Abbreviations } & 11\end{array}$

I Introduction: Land, Customary Law and

Traditional Authorities $\quad 13$

2 How to Combine Tradition and Modernity?

Regulating Customary Land Management in Ghana

Land Use Policy (2008) 25(2), in press

3 Land Policies for Tenure Security or the Reality of

Customary Land Management in Peri-Urban Ghana

Journal of African Law (2007) 51(2): 215-248

W. Zips and M. Weilenmann (eds.), The Governance of Legal

Pluralism. Lit Verlag, 2008, forthcoming

$4 \quad$ Negotiated or Negated? The Rhetoric and Reality of

Customary Tenure in an Ashanti Village in Ghana

Africa (2008) 78 (2), in press

5 Traditional Authority Revisited: Popular Perceptions of Chiefs and Chieftaincy in Peri-Urban Kumasi, Ghana

Journal of Legal Pluralism (2007) 55, in press

6 Courts and Peri-Urban Practice: Customary Land Law in Ghana

University of Ghana Law Journal (2002-4) XXII: 25-77

7 Conclusion: Stool Land Management and the Quest for Customary Law

References

Samenvatting (Dutch Summary)

Curriculum vitae 



\section{Acknowledgements}

An Akan proverb reads Eti nnye borefere na woapae mu ahunu mu nsem, the head is not like the pawpaw that can be split to see the contents. This truism points out that no research in the field of legal anthropology can be done without the collaboration of informants, who answer your questions, explain what you do not understand, and live their lives in your presence. During my periods of fieldwork in Ghana I have encountered many friendly, hospitable people willing to share their life experiences with me. In fact, willing is an understatement, as many Ghanaians were eager to share their views, their joy and grievances, their indignation, their hopes and their insights with a foreign researcher. My position as a foreigner researcher was hardly ever questioned. Even when I expected such remarks most, such as the time when I discussed my research on a talk show at a Kumasi radio station, I was surprised with an enthusiastic listener who phoned in to exclaim his satisfaction that a foreign researcher was finally bringing this story out in the open. My periods of fieldwork have been a most stimulating, precious and pleasant experience due to the friendly openness of the Ghanaian people.

Firstly, there are all those people in Besease, our village of residence, who made us feel welcome, corrected our use of the local language, showed us the village way of life, and provided in-depth views of land management matters in a peri-urban community. A special role was played by our landlady Olivia, her late husband Opoku Thomas, and their children Akwasie, Yaw, and Akua, who opened their home for us and showed us around in our first weeks in the village; our landlady's mother, Adwoa Baedu, who always brightened up our days at the house and protected us against snakes, scorpions, and overly nosy children; and our two other 'housemates', sister Adwoa with her bright laughter and sister Benedicta or 'madam', who made her pupils fetch us water from the wells and could always be called upon to explain local customs or gossip. Furthermore, our neighbor Amma Adoma and her family, Aning Dei, assemblyman Adams Boakye-Yiadom and his wife Agnes, and the chairman and members of the Besease Unit Committee and Plot Allocation Committee, deserve special reference for their kindness and hospitality. My gratitude also goes out to the various 
chiefs of Besease, who - despite my critical attitude and questions have shown me the courtesy that becomes a guest in Ashanti and have granted me several interviews. The two Kontihenes of the village, especially, have contributed greatly to my understanding of land and chieftaincy affairs in the village and its surroundings.

Another part of my research was done in eight other villages in periurban Kumasi, where I am also indebted to many assembly members, Unit Committee members, and other villagers for their kindly bestowed time and information. Also here, the traditional authorities although perhaps not always happy with being the object of my research - were courteous and hospitable. One of them even offered me a position as 'development queenmother' (Nkosuohemaa). In district capital Ejisu, regional capital Kumasi, and national capital Accra, I have learned from the knowledge and insights of many judges, lawyers, civil servants, ministry officials, and researchers. Dr Daniel Hammond and his friendly staff helped me immensely during the start of my research and could always be called upon later, and prof Kojo Amanor has inspired me with his writings and our discussions, and has helped organize an international seminar in Accra in 2006 to disseminate data and compare them with other research.

Two persons were vital in the success of the fieldwork. The first was Niels, who accompanied me to Ghana, where he offered his services to the primary school adjoining the orphanage of Besease. He was a true companion, unrelentingly sharing my enthusiasm for the research as well as for village life in Ghana. Chatting with the villagers on one of our many strolls through the village, drinking Star beer at our favorite local bar, traveling to Kumasi for the Internet and grocery supplies these and many other activities undertaken together have made my time in Ghana a great experience. The second person who was invaluable for this research is Beatrice Newman, who assisted me in the research throughout the fieldwork. She was great to be on the road with, understanding what I was interested in, helping me with the local language, and diverting all attention from the oburoni (white foreigner) to the beautiful town girl. Her knowledge was not only based on a bachelor's degree in land economy and a year of experience as a research and teaching assistant in her department, but also on her being part of a large Ashanti family. When she was not able to answer one of my many questions, she would often surprise me later with an explanation from her mother, father, grandmother, or some other relative. Furthermore, when I needed a number of research assistants to conduct a survey, she mobilized her old university mates, who proved to be hardworking, valuable colleagues.

This research greatly profited from comments by and discussions with colleagues whom I met at conferences or have been in contact 
with through email. In particular I would like to express my gratitude to Osman Alhassan, Adarkwah Antwi, Seth Asiama, Sara Berry, Kwame Boafo-Arthur, Aninka Claassens, Rijk van Dijk, André Hoekema, Kasim Kasanga, Nii Ashie Kotey, Christian Lund, Tom McCaskie, Chris Milley, Pauline Peeters, Julian Quan, Donald Ray, Dzodzi Tsikata, Franz Von Benda-Beckmann, Markus Weilenmann, Melanie Wiber, Gordon Woodman, Marc Yeboah, and Werner Zips.

My many colleagues in Leiden have also highly contributed to my research. First of all the African Study Centre with its excellent library and ever-friendly staff, its Ghana Study Group chaired by Rijk van Dijk, and its many interesting seminars, has provided a valuable platform for learning and comparison. Secondly, the Van Vollenhoven Institute for Law, Governance and Development has proved to be a stimulating environment with a group of valuable colleagues. The research meetings, Tuesday rice lunches, hallway discussions, and various other gettogethers, helped me shape my arguments, learn about new literature, and let off steam when needed. Many thanks to all my colleagues and former colleagues for making the VVI a great place to work. I owe special thanks to Julia Arnscheidt, Gustaaf Reerink, Barbara Oomen, Willem Assies, and Laurens Bakker for my academic development and the joy of sharing my work; to Marianne Moria, Kari van Weeren, and Jan van Olden for organizational issues, absorbing complaints, and friendly chats; to Albert Dekker and Sylvia Holverda for their library assistance; to Alessandra Casano for her editing work; to Hilde Bos and Anne Saab for their wonderful dishes; and to Benjamin van Rooij for combining most of these qualities and more.

Finally, I would like to thank my friends and family, who have often listened attentively to the ins and outs of customary land management in far away Ghana, who have visited in quite some numbers our little place in the village of Besease, and who have never even doubted whether I would make it to the finish. 



\title{
Abbreviations
}

\author{
CA Court of Appeal \\ CLS Customary Land Secretariat \\ DA District Assembly \\ DCE District Chief Executive \\ DFID UK Department for International Development \\ EPA Environmental Protection Agency \\ EU European Union \\ GLR Ghana Law Reports \\ GSS Ghana Statistical Service \\ KVIP Kumasi Ventilated Improved Pit Latrine \\ LAP Land Administration Project \\ LAPU Land Administration Project Unit \\ LC Lands Commission \\ LSA Land Sector Agency \\ MLFM Ministry of Lands, Forestry and Mines \\ MoU Memorandum of Understanding \\ MP Member of Parliament \\ NLP National Land Policy \\ NPP New Patriotic Party \\ OASL Office of the Administrator of Stool Lands \\ PAC Plot Allocation Committee \\ PNDCL Provisional National Defense Council Law \\ SNV A Netherlands based international development organization \\ TCPD Town and Country Planning Department \\ UC Unit Committee \\ UST University of Science and Technology (Kumasi) \\ USAID United States Agency for International Development \\ WALR West Africa Law Reports \\ WACA West African Court of Appeal
}



1 Introduction: Land, Customary Law, and Traditional Authorities

Janine M. Ubink 



\title{
1. Introduction: land, customary law, and traditional authorities
}

\section{Land reforms for poverty reduction}

\begin{abstract}
"Land remains an asset of great importance to African economies, as a source of income, food, employment and export earnings. As well as its economic attributes, land continues to have great social value - as a place of settlement, providing a location within which people live and to which they return-as well as symbolic and ritual associations, such as burial sites, sacred woodlands, and spiritual life." (Toulmin and Quan 2000a: I-2)
\end{abstract}

Access to land and the ability to make effective use of it are critical to the welfare of poor people worldwide. Since land is a key asset for the rural and urban poor, land policies are of fundamental importance for economic activity, poverty reduction, sustainable management, and the well-being of households. In the last decades, many countries in Africa have undertaken land reform in one guise or another, aimed at enhancing the security of property rights (Alden Wily 2003). Despite converging aims, these reforms have varied significantly in the methods applied to achieve them. In the first decades after independence, mainstream land reform ideology held that agricultural productivity was inhibited by customary law unreflexive to an agriculture that was capitalizing and adopting new technologies, and would increase through the creation of individual property rights. Private property was to solve the lack of tenure security which was considered to exist under customary law. Enhanced security would encourage farmers to invest in their land and hence lead to increased productivity (Acock I962; Demsetz I967; Feder and Noronha I987; World Bank I975).

This policy direction was taken, however, without rigorous empirical analysis of the hypothesized causal relationship between individual rights in land and improved tenure security and agricultural outputs in the African context. In the following years research showed that these causal links were not immediate and simple. Mounting evidence was produced that individual land registration and titling programs featured high economic and social costs and negative consequences for the poor (Bruce and Migot-Adholla I994; Coldham I979). As a result, 
policy makers went back on land titling as a panacea for land tenure in Africa and realized that land policy must start from existing realities and systems. Customary systems thus came to be revalued as mechanisms for land access and employment creation (Deininger and Binswanger I999; DFID I999; Toulmin and Quan 2000c).

A return to the local arena as the place of action squared with the liberalization policies of the I990s and donor calls for structural adjustment, emphasizing a smaller state, cuts in public expenditure, and the strengthening of civil society. The adoption of multi-party democracy and democratic decentralization and the trend to consider the state as just another actor in an increasingly complex and interwoven global order, all seem to have opened new public spaces for traditional leadership and local management on the basis of customary law (Englebert 2002: 59; Kyed and Buur 2005: 3; Oomen 2002). Notwithstanding this, the return to local customary realities as the starting point of any tenure reform can be largely attributed to the failure of registration and titling programs (cf. Woodhouse 2003: I7I5) - just as the earlier policies of land titling were inspired by a disappointment with agricultural output under customary tenure. This shows that policy shifts are often driven by 'default reasoning' more than by thorough knowledge of the proposed alternatives, a danger that continues to be eminent in new policies.

\section{Idealizing Research}

Just as policy makers sometimes lack critical assessment of customary land management, some academic studies also seem to be "based on hypothetical models of how land was managed in traditional systems" (Amanor 200I: 63). These studies emphasize that customary tenure regimes embody important principles concerned with equity, social security and the maintenance of ecological balance, and that they are built on core values of negotiation and consensus-building. Kasanga, for instance, speaks of "the egalitarian tenurial systems" and claims that "customary land law offers the best security of tenure to individuals, families and local communities" and that "there are reasonable checks at the local level on almost everybody” (Kasanga I996: 89-100). And Platteau, although claiming not to fall "into the snare of romanticism", but rather displaying "a pragmatic attitude grounded in a realistic assessment of Sub Saharan Africa's present predicament”, makes the following statement about informal village practices with regard to land: “(...) considerations of social security and equity usually dominate pure efficiency concerns (...) customary systems continue to generate a remarkable degree of consensus, in particular on the norms and values justifying land claims" (Platteau 2000: 72). 
A comparable tendency to romanticize 'traditional communities' is found in the literature on chieftaincy, where assumptions abound concerning the egalitarian, inclusive structure of local communities, the democratic nature of chiefly administration and the well-functioning checks and balances on traditional authorities. For instance, Buur and Kyed describe two studies on the role of traditional structures in local government in Mozambique that emphasize the "depoliticized sphere of human relations that, despite colonial impositions, war and displacement, continued to have legitimacy and exercise profound authority. (...) Traditional authorities represent 'the whole community, beyond political differences, embodying the will of all people and not excluding anyone"" (Buur and Kyed 2005: II-I2). These studies culminated in a Decree that recognized traditional leaders as community authorities without a single paragraph to set the terms for the relationship between community and community leader or to ensure the participation of community members in the selection of community authorities. Another example is found in Ayittey's book Indigenous African Institutions in which he claims the following: "Political power or office in traditional Africa was not used as the basis to accumulate wealth"; "The repository of the greatest political power or influence was the Village Assembly of Commoners, giving true meaning to the phrase: "power lay with the common people""; "the chief did not rule; he only led or assessed - an important distinction” (Ayittey I991: 27, 78, 96). See for a last well-known example outside Africa Brody as quoted in Kuper: "For the peoples of the Northwest Coast [of Canada], as to any hunter-gatherer society or, indeed, any oral culture, words spoken by chiefs are a natural and inevitable basis for truth" (Kuper 2003: 39I). ${ }^{\text {I }}$

Many of the above-mentioned studies on customary law and traditional authorities assert the positive attributes of customary law as ideal principles rather than show that they operate in practice, relegating all consequences of social stratification within communities to the background. According to Thornton (2003: 130) "most participants in these debates seem to prefer the ideology to the reality." These 'idealizations' are not without danger, since assertions of a democratic principle of traditional land administration can serve the interests of the local ruling class as a means of ideologically justifying their demand for the state to leave local land administration to traditional rulers (Amanor ı999: I0; cf. Woodhouse 2003).

\section{Commodification of Land}

Studies revealing a lack of security of customary tenure in many areas in Africa challenge the 'romanticized' descriptions of customary law and traditional authorities. This lack of tenure security is often a result 
of commodification caused by various factors such as population growth, the rising value of real estate and the expansion of urban residential areas, the development of new commercial export agricultural sectors, and the extinction of remaining agricultural frontiers. Mounting evidence of increasingly restricted and insecure access to land for the poor majority and increasing inequity in the face of land shortage and competition displays that customary systems are often unable to evolve equitably (Abudulai 2002; Alden Wily 2003; Bruce I988; Kasanga et al. I996; Swindell and Mamman I990).

A number of excellent studies reveal the social differentiation within African communities and emphasize the importance of power structures (Amanor I999; Amanor 200I; Berry 200I; Carney and Watts I990; Daley and Hobley 2005; Juul and Lund 2002a; Oomen 2002; Peters 2002; Ribot 200I; Whitehead and Tsikata 2003; Woodhouse 2003). They describe internal processes of contestation, assertion and transformation and portray political struggles to define and redefine social relations in the customary sphere. A number of these studies demonstrate that local elites have been able to use their position and the ambiguities of customary law to appropriate land to further their own economic and political interests. This includes traditional leaders who have ruled arbitrarily with few checks and balances on their administration, giving power considerations precedence over the objectives of development. Some authors expect that chiefs' dealings with land affect people's views on the tasks and activities of chiefs and their attitude towards chiefs and chieftaincy in general (Claassens 2006: 26; Fisiy I992).

\section{Tenure Security}

The main benchmark for evaluating land tenure ${ }^{2}$ systems is the concept of tenure security. It is broadly defined as the perceived right by the possessor of a land parcel to manage and use the parcel, dispose of its produce and engage in transactions, including temporary or permanent transfers, without hindrance or interference from any person or corporate entity, on a continuous basis (Migot-Adholla and Bruce I994: 3). This definition thus not only encompasses certainty, but also the elements of extent and duration. ${ }^{3}$ Certainty again is a function of two elements: (I) assurance in exerting rights, and (2) the costs of enforcing these rights, which should not be inhibiting (Place, Roth, and Hazell I994: 19-2I). Lund cautions that when the extent and duration of rights determine the measure of tenure security, this seems to imply that private property has the highest tenure security possible. However, while increasing exclusivity may produce more tenure security for the excluding party, the opposite will be the case for the one who is being 
excluded. Thus increasing tenure security for one usually correlates with decreasing tenure security for another (Lund 2000: I6).

Most land reforms aim to enhance tenure security, and policy documents abound with descriptions of the positive effects expected from enhancing tenure security (EU 2004; USAID I986; World Bank $2003 \mathrm{~b}$ ). These include (I) more willingness to invest through an increasing likelihood that the operator will capture the investment returns; (2) enhancing the land's collateral value and improving the creditworthiness of the landowner, thereby increasing not only the willingness but also the ability to invest; (3) increasing production and enhancing sustainability of production through more investment; (4) diminishing the amount of disputes over land, thereby freeing resources that otherwise would have been used for litigation; (5) by putting an end to ambiguity in property rights, reducing transaction costs and thus having a positive effect on the land market; ${ }^{4}(6)$ these five factors all lead to an increase in the value of land (Place, Roth, and Hazell I994: I6-8). Caution is needed, however, with regard to the causal relationship between tenure security, investments, and yields. First, enhanced tenure security will only lead to higher investment demands when the farmer has knowledge of and access to inputs, viable technologies, and advice, and when investments are profitable and investment returns are not too risky. Second, even when demand for investment is enhanced, the absence of household labor and financial resources may prevent farmers from exercising this demand. Small farmers, even when they have a clear and secure title to their land, can still have extreme difficulties in acquiring a loan. Third, land improvements do not necessarily increase yields, as households may target their investments towards reducing yield variance rather than increasing mean yield, or they may prefer leisure or pursue off-farm opportunities (Atwood I990; DFID I999: 9; Shipton and Goheen I992: 317-8). ${ }^{5}$

Evidence thus shows that tenure security does not necessarily lead to increased production. Nonetheless, even if tenure security does not have an effect on production, it is still crucial for the people concerned. It is first and foremost needed to guarantee continuation of current use rights, i.e. for 'maintaining the status quo.' Many people depend on land for food and some additional income through market sale of surplus production. Tenure security of this land is thus of vital importance for their well-being and survival. Or, as Migot-Adholla and Bruce (I994: 7-8) put it, the right of continuous, unchallenged use of agricultural land is perhaps the most critical measure of security of tenure. 


\section{Contestations over rights to land in peri-urban Ghana}

Areas with land commodification make interesting cases for the study of the functioning of customary law and traditional rule and the regulation of customary tenure systems. They provide a dynamic environment in which to analyze the following questions: How do traditional authorities regulate customary land in the changing setting? How does this affect the tenure security and livelihoods of local farmers, and to what extent can these farmers influence local land management and traditional rule? How do the various actors attempt to use, transform, or create customary law in this process? To what extent and in what ways do governmental actions and discourse influence local land management and the development of customary law? Are state courts important actors in the ensuing struggles?

\section{Ghana}

Like most African countries, Ghana has in the last decades witnessed an increasing commodification of land, which has resulted in attempts to redefine land ownership and tenure and in contestation of rights to land. At the heart of these contestations lie the issues of the authority to allocate rights to customary land and the entitlements to the proceeds from such allocations. For instance, peri-urban areas witness severe struggles between farmers and families on the one hand, and chiefs on the other, over the right to convert farmland into residential land. ${ }^{6}$ In agricultural areas similar struggles over land and its proceeds can be witnessed. Amanor (I999; 200I) describes in detail how new land pressures and commodification have led to contestations and redefinitions of rights to land and labor in the cocoa, oil palm, and forestry sectors of Ghana. Others describe how chiefs have tried to tap a 'gateway to prosperity' by allocating land to migrant pastoralists for substantial payments to the detriment of indigenous farmers (Tonah 2002: 53-57), and point to struggles over the right to lease out land to tomato growers (Berry 1997: I235). These and other struggles for land in the local and national arena have resulted in deteriorating access to land and security of tenure for immigrants, pastoralists, youth, women and the poor (Alden Wily and Hammond 200I).

Ghana is especially interesting for studying customary tenure systems, since it is a state characterized by strong legal and institutional pluralism. The position of traditional authorities ${ }^{7}$ in Ghana is, if not unique, at least exceptionally strong in comparison to other African countries. In the colonial period the British ruled the Gold Coast through traditional leaders. Their naive assumption that the traditional government arrangements in the various communities must all be like 
those found among the Akan communities, combined with their preference for clear hierarchical structures, led in some areas to the invention of traditional leaders that had no root in tradition, and in other areas to invented or strengthened hierarchies among traditional leaders (Kumado I990-1992: 196-7). The British made several inroads into the authority of the chiefs, for instance, by making the position of the chiefs dependent upon governmental recognition, by weakening and circumscribing their 'judicial' powers, and by restricting some of their powers over land (Kumado I990-I992: I97-200; Ray I998). While under indirect rule the chief lost his independence, he at the same time increased his powers over his subjects because the traditional checks and balances to his authority were watered down by the colonial authorities. The result was the weakening of the ties between the chief and his subjects, and this led to many destoolments and attempted destoolments (Kumado I990-1992: 203).

The first government after independence seriously tried to curtail the powers of the chiefs, but subsequent governments have been more or less supportive of the chiefs. Besides the creation of a system of elected local government which gradually diminished the role of chiefs in local government issues, they have mainly implemented a laissezfaire policy. The 1979 Constitution eliminated the requirement that chiefs selected by customary practice must be ratified in their positions by the central government (Kofi-Sackey 1983: 72; Van Rouveroy van Nieuwaal 1987: 19). This requirement was briefly reinstated in 1985, but the position of chiefs is again guaranteed in the 1992 Constitution which withholds any power from Parliament to "confer on any person or authority the right to accord or withdraw recognition to or from a chief" (article $\left.270(2)(a)^{8}\right)$. This power was given solely to the Traditional Councils and the Houses of Chiefs who are charged with chiefly succession and status disputes (Ray I998: 6r). Traditional leaders in Ghana are thus recognized by the state, but are not transformed into mere state agents; they possess political power in many localities, without being politically co-opted by the regime in order; and they are not reduced to a mere 'folklorized' version of themselves, as described for some other African countries (Van Binsbergen I999; Van Rouveroy van Nieuwaal 1996: 43; Von Trotha 1996: 87).

The Constitution recognizes customary law as a source of law in Ghana (article II) and explicitly states that both the selection of chiefs and the management of stool land are to be "in accordance with the relevant customary law and usage" (articles 267 (I) and 270 (2) (a)). It vests all customary or stool ${ }^{9}$ lands - which constitute approximately $80 \%$ of the land in Ghana - in the appropriate stool on behalf of and in trust for their people, and confirms that such lands be managed according to the fiduciary duty of the traditional authorities towards their 
people (articles 267 (I) and 36 (8)). The origins of the formulation of customary tenure date back to the struggles of the British administration in the early colonial period to control land and vest it in the colonial state, and to the creation of a system of indirect rule. In the I89os the rapid pace of land sales and mining concessions were of concern to the colonial government that had little control over the process (Amanor 1999: 46). The British attempted to enact legislation which would place all "unused land" under the Crown and enable the colonial government to control the granting of concessions (Berry 200I: I-27; Lentz 2006: 7-8). These attempts met with considerable opposition from the traditional and modern Gold Coast elite. The Gold Coast intelligentsia developed a literature on customary land relations (Hayford I970; Sarbah I968) in which they couched their propertied interests in terms of the customary rights of Africans to land and the violation of customary law by colonial interventions (Amanor I999: 47-9). Colonial policy circles in this period were polarized by debates between those who supported constructivist imperialism and a more laissez-faire policy based on liberalism. The liberal policy gained ascendancy, and a policy of indirect rule was established in which colonial rule was affected through an alliance with traditional rulers organized into Native Authorities, overseen by District Commissioners. From this period, the management of land came under the authority of chiefs and the British colonial administration supported the privileges of chiefs and their control over land and natural resources. A theory of African communal tenure was developed, in which land was vested in chiefs to manage on behalf of their communities and in which chiefs were recognized as the only social group that could transact land (Amanor I999: 52-3). By controlling chiefs, the colonial government was thus able to control land. This construct of customary communal tenure did not reflect the social relations and permanent alienations in land that had existed in the nineteenth century (Amanor 1994; Hill I963: chapter V; Rathbone 1996; Wilks I975).

Commoner perceptions of wide-scale abuses of privileges by chiefs under indirect rule led to many destoolment actions against unpopular chiefs, as in for instance Akyem Abuakwa (Firmin-Sellers I995: 868). By the late I940s the Native Administration system had alienated much of the population, who called for the establishment of a system of local democracy and the reduction of the role of the chief. Although this led to the creation of a system of democratically elected government in the I950s, and a gradual demise of the importance of chiefs in local governance issues, traditional authorities continued to enjoy rights of control over land. Since independence, successive governments have continued to maintain the claims of chiefs on privileged rights in land. Under the current NPP government, the pivotal position 
of traditional leaders in land management might even be enhanced by the Land Administration Project Ghana, a long-term program with multi-donor support, started in 2003, under which the government is piloting the management of stool lands by Customary Land Secretariats under the aegis of traditional authorities (DFID 2004; Ministry of Lands and Forestry 2003: I2). ${ }^{10}$

\section{Peri-urban Kumasi}

In this book, we study the area of peri-urban Kumasi to examine the regulation of customary tenure systems and the functioning of customary law. Peri-urban areas form tenure hotspots where property relations are subject to intense contestation and where access to wealth and authority undergo rapid change. The peri-urban area is most appropriately thought of as an interface zone, approximating a continuum from rural to urban. It is characterized as having a rural basis with strong urban influences, easy access to markets, services and other inputs, ready supplies of labor but relative shortages of land and risks from pollution and urban growth (Edusah and Simon 200I; Simon et al. 200I). Due to expansion of urban centers and population growth, periurban areas witness a high demand for residential and sometimes commercial land, which triggers struggles over the rights to convert farmland, cultivated by community members, and to sell it for other purposes. Since traditional authorities maintain a strong position with regard to land, they play a prominent role in these conversions.

Peri-urban Kumasi, the zone around the capital of the Ashanti Region, is a case in point. Kumasi, a bustling city and an important transportation hub, houses the still vibrant royal court of the Asantehene, ${ }^{\mathrm{II}}$ the powerful king of all Asante. Its population has grown by $4.2 \%$ annually since I960, to I,400,000 at present. This has led to the abovementioned pressure on land in the peri-urban area. Increasingly farmland is being converted into mainly residential, but also commercial and industrial, land, especially alongside the major roads to Kumasi, where access to the city is easy and where electricity is available. Many peripheral villages have now become fully encapsulated by Kumasi.

\section{Customary law}

For customary land tenure systems the terms and conditions on which land is held, used, and transacted are regulated by customary law. This, however, is a much debated and not unproblematic phenomenon that has troubled researchers, administrators, lawyers, and judges alike, from the colonial period until the present. What is customary law? 
Where can we find it? How do we study it? Even the term itself is ambiguous, as it evokes an image of an unchanging, antiquarian, and immutable normative system, whereas historical and anthropological research has revealed that customary law is dynamic and the historical result of interaction between local actors and state intervention (Benjaminsen and Lund 2003a: 2; Juul and Lund 2002b: 3; Lavigne Delville, Ouedraogo, and Toulmin 2002: 9; Migot-Adholla and Bruce I994: 3-4; Sklar I999: I20). ${ }^{\text {I2 }}$ As these questions underlie all other aspects of customary land management, the efforts of various local and supra-local actors to use, ascertain, transform, create, and recreate customary law will form a recurrent theme in this book. To offer background on this aspect of the research, I will now provide a broad sketch of the literature relevant to a number of these issues.

In the same way it had been discussed with regard to Asia, from the beginning of European contact with Africa, researchers and administrators hotly debated whether 'primitive' societies in Africa could be considered to have law. In the early twentieth century, two distinguished anthropologists dominated this debate about the definition and essence of law. Radcliffe-Brown, who defined law in terms of politically organized sanctions, concluded that preliterate societies had no law (Radcliffe-Brown I933). His contemporary, Malinowski, instead defined law as the processes of social control by which any society maintains order and discourages disorder, which led to the conclusion that every society could be said to have law (Malinowski ig26: 50-68). This last view became dominant among future generations of researchers studying primitive societies (Nader 2002: 85-6). ${ }^{\mathrm{I3}}$

A new controversy arose around the question of methodology. How to study the unwritten - tribal, customary - law of a society? Early legal anthropologists and colonial administrators tried to ascertain rules of customary law through conversations with traditional leaders and other 'experts', to be conserved in textbooks and codifications. Danquah's I928 Gold Coast: Akan Laws and Customs and the Akim Abuakwa Constitution and Shapera's I938 A Handbook of Tswana Law and Custom are well-known African examples. ${ }^{\text {I4 }}$ In I94I, legal realist Llewellyn and anthropologist Hoebel published their joint work The Cheyenne Way. The authors were of the opinion that "the safest main road into the discovery of law" was through the study of disputes or 'trouble-cases', since "not only the making of new law and the effect of old, but the hold and the thrust of all other vital aspects of the culture, shine clear in the crucible of conflict" (Llewellyn and Hoebel I94I: 29). This book was a response to the case law method for teaching law at American law schools - introduced by Langdell, who became the Dean of Harvard Law School in I870 - which stressed the order and logic in the law. Legal realists criticized this view for severing the ties between the 
study of law and everyday life (Nader 2002: 89). By studying the law of the Cheyenne Indians mainly through an investigation of disputes, Llewellyn and Hoebel tried to show that "law is not an autonomous phenomenon separated from its cultural matrix" (Pospisil I973: 539), and that the study of trouble-cases "offers a possibility of study of a culture at work on and through its people, for which no schematization of 'norms' can substitute" (Llewellyn and Hoebel I94I: 28). They acknowledged that the study of disputes could not be fully understood without a reference to abstract norms or rules and to the actual behavior of members of a society (Llewellyn and Hoebel I94I: 2I). Still, their arguments were largely based on fifty-three trouble-cases, and their work induced a generation of legal anthropologists to concentrate almost exclusively on conflict and its resolution.

In the I950s and 6os several major works were produced in this field that advocated the study of customary law through an analysis of actual processes of adjudication, mostly restricted to public forums (Bohannan I957; Gluckman I955; Gulliver I963; Nader I969; Pospisil I958). Pospisil, for instance, restricted the field of law to the rock-bed of legal decisions and such principles as could be abstracted from them, thus excluding stated rules not confirmed by such decisions (Pospisil I958: 256-7, cf. Ter Haar and Supomo I950: 475). These studies challenged the older approaches of ascertaining customary law through conversation with experts. Although it lost considerable ground, this approach did not fully disappear. It was for instance still followed by Allott (London School of Oriental and African Studies), who started an ambitious project of Restatement of African Law, that aimed to abstract and systematize the unwritten rules of African customary substantive law (Cotran I968-9; Ibik I970-I; Kludze I973; Roberts I972; Rubin I965). ${ }^{\text {I5 }}$

Some scholars have criticized the case method approach as unduly restrictive, complicating the necessary analysis of the full range of socio-legal occurrences. (Malinowski I94I-2: I252; Moore I970: 270; Nader 2002: 97). A well-known proponent of this view, Holleman, propagates a move away from an exclusive focus on situations of dispute to an analysis of ordering in non-dispute situations (Merry i988: 890). He observes that: "in the study of the substantive law and its practice, and in a field of law in which litigation is rare, a fieldworker relying mainly on a case-method focused upon actual trouble-cases may get a skewed idea of the accepted principles and regularities in this particular field. (...) The trouble-less case then becomes a necessary check on the trouble-case, rather than the other way around" (Holleman I973: 599). ${ }^{\mathrm{I} 6}$ He therefore pleads for a much closer integration of, and equal emphasis on, all components of the "methodological triad of legal anthropological approach": normative statements (rules/norms), prac- 
tice (troubleless cases) and disputes (trouble cases) (id.: 606-7). It should be noted here that Holleman's point of departure was that through a combination of these methodologies, the customary rules, valid in a certain locality at a certain period of time, could be ascertained. Criticism was also heard from within the group of scholars focusing on disputes. By the I970s a crucial move was underway to shift the focus from the description and analysis of dispute settlement institutions to the description and analysis of behavior connected with disputing (Just I992: 373-4). The processualists, represented by legal anthropologists such as Nader, Starr and Gulliver (Gulliver 1979; Nader and Todd Jr. 1978; Starr 1978), analyzed the entire process of conflicts in their total social context, thereby effecting a shift away from judge- and judgment-oriented accounts of dispute settlement that see customary rules as having the capacity to determine the outcome of disputes in a straightforward fashion, towards analyses that see customary rules as objects of negotiation and a resource to be managed advantageously (Comaroff and Roberts I981: I4; cf. Just 1992: 374).

In the next decade scholars studying disputing made an effort to synthesize the rule-centered approach and the processual approach (Moore 1978; Moore 1986; Comaroff and Roberts I98I). Comaroff and Roberts, in their study on Tswana disputing, show that rules governing conflict behavior were not internally consistent codes of action analogous to western written law but were instead negotiable and internally contradictory repertoires that were applied with discretion (Merry I992: 360). Arriving at this conclusion, the authors challenged the existence of one set of ascertainable, valid rules, just as the processualists had done before them. Another scholar who has questioned the possibility of finding the valid customary rules of a certain group of people is Martin Chanock, who observes in his work Neither Customary nor Legal: African Customary Law in an Era of Family Law Reform that within each group there will be variations within and conflicts about customary rules, which finds expression both in normative statements of group members and in their actions (Chanock 1989). Analyzing the application of customary law by colonial officials, he concludes that what is represented as the ascertainment of valid rules of customary law by officials often entails a political choice from various locally existent versions (cf. Chanock I998: xi).

Research in $\mathrm{n}$ the I980s and I990s shows an increasing attention to how legal institutions and actors create and transform meanings, and a greater concern with the ways law both reflects, constructs, and deconstructs power relations (Collier I988; Merry I992: 360). This research reinforced the insight that there was no such thing - and never had been such a thing - as a fixed body of customary law ready to be ascertained, but that customary law was fluid, relational, and negotiable, 
and was intimately tied to fluctuating social and political relations (Oomen 2002: 2I). With regard to official versions of customary law, this insight led to the conclusion that what had been portrayed as the ascertainment of customary rules by colonial administrators and judges was actually, at least partly, an invention of tradition. Revisionist scholars displayed how official interventions, such as codification and judicial applications, created a customary law changed in form, content, and effect (Fitzpatrick 1984: 2I-2). This was done in a dialogue - albeit within highly skewed power relations - between colonial administrators and African people (Chanock 1998; Mamdani 1996; Mann and Roberts I99I; Merry I992: 364; Moore 1986; Ranger I983; Snyder I981a). ${ }^{\text {I7 }}$ Whereas in the past legal anthropologists mainly restricted the context of analysis to the local situation, there now came ample attention for the interaction between local and supra-local levels and the mutually constitutive nature between local customary law on the one hand and state law and official customary law on the other (Allott and Woodman I985; De Sousa Santos 1987; Griffiths I986; Moore I986; Oomen 2002; Vanderlinden I989; Von Benda-Beckmann I984b; Von BendaBeckmann and Strijbosch I985; Woodman I988). ${ }^{\text {I8 }}$ This led to an increasing awareness and often condemnation of the gap between local customary law - sometimes termed 'living law' (Ehrlich I936; Moore I973) or 'sociologists customary law' (Woodman I977) - and official customary law as pronounced in court judgments, textbooks, and codifications (Tamanaha I997: I02).

Although the problem of official representation and application of customary law by judges, legislators, and policy makers has been discussed by many eminent scholars, it still remains unresolved. The field seems to suffer from a limited cross-fertilization between, on one hand, the legal knowledge of processes of adjudication, law making and codification and the legal reasoning of officials, and on the other, the legal-anthropological knowledge of how local customary law functions. While many legal scholars and practitioners writing on the issues of ascertainment and codification of customary law (such as Allott I960; Allott 1970; Asante 1969; Bennett 1985; Elias 1958; Kludze I985; Osinbayo and Kalu I99I; and Zorn and Care 2002) have taken the state legal system and the role of state officials as their main reference point, paying limited attention to complex local realities, the value of many anthropological descriptions lies in their contribution to the study of comparative jurisprudence; however, these descriptions "can hardly have much impact on the more mundane level of the day-to-day administration of justice" (Allott I969 in Moore 1992: 23) or be used in "the search for a local law" (Chanock I998: vii) of the communities investigated (Elias I958; Poulter 1975: I82). Systematic studies, building a bridge between these two kinds of knowledge to understand not 
only the local functioning of customary legal systems, but also the ways in which officials confronted with the complex reality of negotiable and fluid norms interpret, apply, and transform customary law, are rare. ${ }^{\text {I9 }}$ The present book aims to contribute to this field by constructing some of the pillars required to support this bridge.

\section{Research questions and methodology}

\section{Main Research Questions}

In this book the study of the local functioning of customary legal systems and traditional rule and the way officials apply and interpret customary law is based on an analysis of customary land management in peri-urban Kumasi. As said previously, in this geographical area customary tenure is under high pressure and customary norms and rules are being contested in numerous struggles and negotiations in which traditional authorities often play a central role. These contestations bring to the fore questions regarding how customary law evolves in the localities and the way officials respond to those changes. Thus, the main research questions are: I) How is stool land managed by traditional authorities, what effects does this have on the tenure security and livelihoods of the various local actors, and what factors can explain these outcomes and their winners and losers? 2) What role does customary law play in stool land management; how and to what extent do the various actors try to defend, reshape, expand and capitalize on their customary rights to land; and which factors can explain their degree of success? 3) How, to what extent, and with what objectives has government policy sought to regulate customary land management over time, and what have been the effects? 4) To what extent do state courts serve as an alternative channel for restraining chiefs in individual cases, and which factors can explain the limited effect of court decisions on local practices in general? 5) What effect does the role of chiefs in stool land management have on their positions and tasks and on the institution of chieftaincy? 6) How and to what extent do international policy pressures translate into national policy; how do lawmakers, national and international policy makers, and judges interpret, apply and build on customary law; which factors explain their method of working; and what normative bench-marks should guide their search for customary law?

The scope of this research goes beyond peri-urban Kumasi. Many countries, especially within sub-Saharan Africa, but also outside, are faced with issues of commodification of land, increasing inequity in customary land management, and the roles of traditional authorities and (weak) governments therein. The present study hopes to contribute to existing knowledge and understanding of customary land man- 
agement, traditional rule, and customary law and the way officials discover, interpret and apply it in Ghana as well as in other countries in Africa and beyond. For this purpose, a further research question is needed: 7) What new insights (for Ghana and in theory) do the answers to the questions posed above provide about customary land management, the application of customary law and the functioning of traditional rule?

\section{An Interdisciplinary and Multi-level Analysis}

It is commonly acknowledged that struggles for land are never merely a question of land, but also a question of property, ${ }^{20}$ and that property is not about things, but about social and political relationships between and among persons with regard to things (Lund 2002: II; Moore I998: 33). Contestations over land and its revenues can thus not be disentangled from struggles over rules, political authority, and social and cultural capital, and are heavily influenced by the specific social, political and historical-geographic contexts (Bassett I993: 2I; Berry I997: I228; Juul and Lund 2002b: 4). Research into customary tenure thus requires an interdisciplinary, processual and institution-focused approach, encompassing aspects of the studies of law, anthropology, political sciences and public administration. These varying disciplines are necessary to study not only actual dealings with land, but also the underlying struggles to define rules of 'customary' tenure and - since claims of an institution to define property are also claims to the institution's legitimacy itself (Berry 2002b; Lund 2002) - to affect, enhance, or change authority.

Questions with regard to customary land tenure obviously need a thorough analysis of village affairs, as property regimes are only as robust, solid, and enduring as the ongoing reproduction or re-enactment which enables them to persist (Juul and Lund 2002b: 4). Analyzing customary land tenure firstly requires the mapping of the various local actors involved. Families, farmers, chiefs, elders, heads of families, local government representatives, women, youngsters, and immigrants all have different interests in land. How and to what extent do these actors try to defend, reshape, expand, and capitalize their rights to land? What pallet of, negotiations, power plays, and struggles is encountered in the villages? To what extent and how is customary law used as a resource in local struggles? How do current developments influence the actors' positions and livelihoods? However, as the local arena does not function as an autonomous social field (Moore I973), local contestations for land cannot be studied by focusing exclusively on the village level. They require a multi-level analysis taking supra-local actors into 
account. In this study, a number of supra-local institutional actors are of special importance.

Firstly, as chiefs play a pivotal role in land conversions, village affairs are heavily influenced by traditional authorities surpassing the village level, i.e., paramount chiefs and the Asantehene. Are they combating sales by their village chiefs or, on the contrary, condoning or even encouraging them? What position do they take when village chiefs are brought to their courts with charges of land mismanagement? What is the nature of the relationships between village chiefs and their superiors? To what extent do the superior chiefs try to influence the enstoolments and destoolments ${ }^{2 \mathrm{I}}$ of village chiefs? Do they claim part of the revenue from village land conversions for themselves? What example do they set in their own land administration? Do they use their power and esteem to set certain rules of proper behavior and guidelines for the division of revenue? Do they attempt to use, create or transform customary law as legitimation for chiefs' actions?

A second institution influencing village land tenure is the government. The Ghanaian government is not all-powerful, and local arenas are relatively autonomous. The interventions of the government may not be hegemonic, "the degree to which their 'intrusive' acts (Berry I993: IOI) influence the patterns of access to and use of land needs to be a question rather than a conclusion that they have limited effect" (Peters 2004: 294). Through legislation, policy, and public administration, the government is a partner in stool land management. The Constitution recognizes that stool land is vested in the stools, and the Land Act prohibits the vesting of freeholds on customary land; but how should these provisions be interpreted? Land sector agencies are mandated to be involved in the collection and distribution of stool land revenue, the provisioning of consent and concurrence for allocations of stool land, and in land use planning. How do these agencies function in practice? How are their tasks interpreted by street-level bureaucrats (Lipsky I980)? What is the local effect of their activities, and what are the constraints on their functioning? What role do local government representatives, active at the village level, play with regard to customary land tenure, and what are their relationships with traditional leadership? What attitude do higher levels of government display with regard to chieftaincy and land affairs? What can be deduced from governmental and political discourse? How do policy makers interpret and work with customary norms and processes? Can the government control chiefly land management, or is this inhibited by the close ties between the current governmental and traditional elite (Amanor I999)? What effect will Ghana's Land Administration Project have on local power configurations? 
State courts and judges could also have an influence on local land tenure. But are state courts accessible to the average peri-urban villager, or to the poor sectors of these communities, and do these people want to take their cases to this forum? Do state courts often try stool land cases, and if so, what kind of issues are tried? How do these courts gain knowledge from and interpret and apply customary law? Do court decisions protect smallholders or find favor with the chiefs' actions? And what kind of effects do court decisions have on village affairs? How wide is the often mentioned gap between court decisions and local practices, and how can it be explained?

Finally, as "(g)lobalization would appear to be a permanent characteristic of Asante” (Woodman, Wanitzek, and Sippel 2004: I77), the developments in peri-urban Kumasi cannot be understood without looking at global developments and actors at the supra-national level (cf. Von Benda-Beckmann and Von Benda-Beckmann I999). Globalization leads to a decline in the unique and overwhelming power of the nation-state through an increasing influence of the international arena (Woodman, Wanitzek, and Sippel 2004: 3-4). For instance, international policy pressures towards structural adjustment and decentralization open up public space for traditional authorities. The World Bank has in 2003 provided a US\$ 5 million grant directly to traditional authorities in Ghana, bypassing the government. At present, international donors and policy makers furthermore largely favor privatization of land and the establishment or enhancement of a free market in land (EU 2004; USAID I986; World Bank 2003b). How do these pressures translate into national policy, such as in Ghana's Land Administration Project?

\section{Historical and Other Bench-marks for Customary Land Management}

This research intentionally limits itself to a description and analysis of current developments and does not attempt to sketch a comprehensive picture of allocation of customary rights and duties in earlier phases of Ghanaian history. Even if such an endeavor were desirable, it would be extremely complicated, as a number of excellent historical studies presenting struggles, contestations, and negotiations for the rights to land in former eras of Ghana and the Gold Coast reveal large differences in normative statements and actual practices between and within areas and periods of Ghana (Amanor 2008, forthcoming; Berry I993; Firmin-Sellers I995; McCaskie I984; McCaskie I995; Rathbone I996). To quote Martin Chanock, "we do not have a 'traditional' world as an identifiable baseline" (Chanock I998: I0). Historical sources should thus be seen as providing particular representations rather than universally accepted descriptions of certain historical processes and occurrences. 
Reference will be made to these sources to demonstrate how certain groups or individuals have represented norms and practices over time.

As said previously, the extensive variation in and struggles about norms and practices have characterized customary land management throughout history. This variety has always complicated the already difficult task for judges, administrators and even anthropologists to determine the 'valid customary norms of the moment.' Written representations of customary law in case law and certain textbooks can thus reasonably be expected to diverge to a certain extent from customary law practices in the localities, or to represent only one of the various practices found locally. Nevertheless, I describe and use them in this book, to provide at least some sort of bench-mark for the complexity of struggles and contestations. As with historical sources, they should not be seen as attempts to sketch the reality of customary law in the localities, but rather as representations by certain actors, or indicators of how these actors interpreted customary law at a certain time.

\section{Methods}

My first acquaintance with Ghana was in I999, when I was still a student, and the idea of PhD research had not even crossed my mind. I visited an SNV-sponsored ${ }^{22}$ Legal Awareness Program, run by the formidable lawyer Hilary Gbedema. Hilary and her team of 'legal literacy volunteers' went into the remote villages of the Volta Region to educate communities on the rights of women and fought legal battles in court to defend these rights. Reading through the files of these cases and following the volunteers on their tour to the villages, it became clear that rights to land were at the heart of many of the battles fought within the program. The paramount importance of land for rural people was a lesson that would influence my later research.

In 200I, while drafting a PhD-proposal, I returned to Ghana for two months to put my initial research questions to the test. My main research question at that time focused on how judges 'deal with' customary law. I was intrigued by how judges, accustomed to the British legal system, gain knowledge of customary law, especially in the fields of land and family matters. These judges are academics, educated in the capital Accra or sometimes even in the UK, having had one or two courses on customary law in their whole curriculum. What knowledge do they have of the customary law, in their geographical jurisdiction, that varies from one ethnic group to the other and that changes over time and adapts to new circumstances? Although most judges interviewed agreed this was a most interesting theoretical question, they also candidly admitted that in almost all cases they 'found' customary law by turning to precedent, without so much as a thought to collect- 
ing any sociological evidence. It would thus be hard to find cases to study this issue and collect enough material to write a $\mathrm{PhD}$ thesis. Although this was a bit of a disappointment at the time, it was soon compensated by the fact that the fields of law that I had in mind for analyzing judicial customary law - land and family law - did turn out to be very interesting. Land, especially, was an extremely hot topic in Ghana, and was not only debated in state courts, but also in local arenas, at traditional councils, by local government representatives, street level bureaucrats, high-level policy makers, and by international donors and financial institutions.

As a result of this trip, I broadened the focus of the research from the courts to all levels and institutions involved in land tenure. After a year of reading up on legal, anthropological, political, administrative, and historical material on the topic, I revisited Ghana in 2002 to select the geographical region for the field research, or rather the peri-urban area that I wanted to settle in, for I had decided to focus on an area with high demand for land. Kumasi, a bustling city with a pleasant atmosphere, rapidly swallowing the neighboring villages, came out top of the list, not in the least because it also houses the royal court of the Asantehene and thus forms the centre of gravity of a strongly hierarchical and vibrant chieftaincy. Furthermore, I was so lucky as to come into contact with an interesting research project on 'land law and its legal institutions', carried out by the University of Science and Technology in Kumasi in collaboration with the Institute for Development Studies at the University of Sussex, UK. One of the participating researchers, Dr Daniel Hammond, enthusiastically invited me to collaborate and promised practical assistance with initial logistics, which later proved to be a great asset.

The next eight months were spent on learning the local language, Ashanti-Twi, taking courses in field work methodology, reading additional literature and anything else geared towards the real fieldwork. In March 2003, my partner and I left for almost a year of fieldwork in peri-urban Kumasi. My first task was to find a village to settle in. I toured the major roads leading to Kumasi, watching for construction work to determine the borders of the peri-urban interface of interest for the research, and visited the various District Assemblies of the area and a number of villages in each interesting district. To avoid entering the villages through the chief, I first approached either the local representative of the District Assembly or a member of the Unit Committee, the lowest level of local government in Ghana. It soon became clear that most villages within a certain zone witnessed their own struggles and negotiations over land, which would provide insights into customary land tenure. But how to decide in which village to settle? 
Before leaving for Ghana, I had asked many people who had preceded me in local field research how they had selected their residence. Among them my supervisor, originally trained as a lawyer, who, half bashful, half proud, answered that his wife, a social anthropologist, had made this decision. When I repeated my question to her, she gave the somewhat disconcerting answer that besides all kind of practical considerations and reflections concerning the content, a place also had to 'feel right.' I remember wondering whether a village has a feel, at least one that becomes visible upon a first or second visit, and I strongly doubted whether I would possess the antennae to pick up such 'obscure vibrations.' However, history would prove her right. I had already visited a number of villages where people had told interesting stories with friendly candor and sometimes even warm pleas to select their village, but no particular 'feeling' from my side. Then I visited Tikrom, and before I was well out of the taxi, a strong tension seemed to cover me like a blanket. This village later turned out to be a place with serious struggles over land and authority, where accusations of threats, bribery, and even talk of suspect deaths were heard. It was an ideal case-study, which I therefore included in my research, but not the preferred village in which to spend almost one year. A similar, but reverse, feeling came over me in the last village I visited, Besease. Despite numerous struggles regarding land, the atmosphere was pleasant and relaxed, and I soon made the decision to settle there.

Besease became the initial fieldwork site and operating base from which to visit eight other peri-urban villages, four of which were, like Besease, situated on or near the road from Kumasi to Accra - Jachie, Tikrom, Adadeentem, and Boankra - and four on the road from Kumasi to Obuasi - Ahenema Kokoben, Kotwi, Brofoyeduru, and Nkoransa. All villages lie within a range of ten to forty kilometers from Kumasi, and could therefore easily be reached by local minibus (trotro). In these localities I combined participant observation with semi-structured interviews with farmers, chiefs, elders, youth leaders, local government representatives, and religious leaders. At the end of the fieldwork period I supplemented my qualitative research with quantitative data, obtained by conducting a survey among 240 households.

I combined this local fieldwork with regular visits to the district capital Ejisu, the regional capital Kumasi, and the national capital Accra, to interview judges, lawyers, politicians, civil servants, policy makers, academics and donors on the one hand, and to study literature, policy documents, court records, and archival records on the other. Access to documents was mostly easy and merely required some patience and friendliness, although that did not guarantee the documents' quality or continued existence. One place where I spent a considerable amount of time was at the premises of the Council for Law Reporting, the institu- 
tion in charge of the publication of annotated case-law in the Ghana Law Reports (GLR). As the council was understaffed and underfunded there was a severe backlog and the most recent GLR at the time of my fieldwork covered the years I993-1996. To realize my goal of comparing court decisions of customary land cases with peri-urban practice, I thus had to sift through all decisions collected from the superior courts of judicature, which were to be found in large numbers of huge heaps of paper in the library.

The combination of studying local, district, regional, and national actors and institutions, which I perceived as highly stimulating, produced a rich set of data, allowing for a thorough multi-level analysis of customary land management in peri-urban Kumasi.

\section{Outline}

As it seeks to gain insights in the functioning of customary law and traditional rule through a multi-level analysis of customary land management in peri-urban Kumasi, this book is divided into chapters dealing with a variety of actors at various levels. Chapters 3, 4 and 5 deal with local actors in Besease and peri-urban Kumasi, centering on farmers, chiefs and elders, local government representatives, and other opinion leaders. The other chapters analyze the activities and attitudes, respectively, of the government of Ghana (Chapter 2), national and international policy makers (Chapter 2 and 3), and courts and judges (Chapter 6). Chapter 7, the concluding chapter, will draw together the various actors and levels to form a comprehensive picture of the operation of traditional rule and customary law in the field of land management in peri-urban Kumasi.

Chapter 2 describes governmental influence on stool land management. To what extent, how, and with what objectives has government policy sought to regulate land management by chiefs over time? And what are the consequences of this regulation? The functioning of a number of governmental institutions, the discourse of the government on issues of customary land management, and the current activities undertaken in the Land Administration Project Ghana, are assessed for their risks, challenges, and impact on local struggles for land.

Chapter 3 first investigates how policy makers have perceived customary tenure systems over time. It describes policy changes with regard to tenure security and the role of customary norms and authorities therein. It shows that international and Ghanaian land policy is currently witnessing a renewed interest in customary tenure systems, and argues that this shift is mainly inspired by the practical necessity to start from existing systems and is based on 'default reasoning' 
brought about by disappointment with state programs of titling and registration. This chapter then turns its attention to land management practices in peri-urban Kumasi and argues that a specific set of factors enables chiefs to profit disproportionately from peri-urban land conversions and complicates the possibilities of local farmers to resist conversions. These factors lie respectively within the traditional system itself and in its interaction with the government. The combination of erosion of customary checks and balances on chiefly functioning and the government's 'policy of non-interference' in chieftaincy affairs has seriously disrupted the fragile balance between chiefs and people. This has given chiefs the power to abuse their prominent positions as guardians of stool land and experts of the customary realm to manipulate customary law to legitimize their claims.

Chapter 4 zooms in on Besease to provide a detailed analysis of struggles for rights in stool land in one peri-urban village. With its microscopic view of processes of contestation it displays several actors, actions, and arenas that resurface throughout the book. It questions the current trend to place all local dealings with land under the term 'negotiations', even when one party outright negates or redefines the other party's rights, and emphasizes the necessity of taking local stratification and power inequalities into account when assessing customary tenure systems.

Chapter 5 deals with the question of how peri-urban land management by traditional authorities, often leading to a loss of land for indigenous farmers, has influenced popular perceptions of chiefs and chieftaincy. Statistical data reveal the seeming contradiction between the highly critical attitude of many farmers towards land management by their chiefs and the people's continued support for the institution of chieftaincy. As the way people feel about their chief seems not to influence their opinion of the institution of chieftaincy, reasons for the popular support for chieftaincy result not from a high level of satisfaction with the way chiefs perform their tasks, but are rather found in the realms of custom and identity. This squares with the fact that in periurban Kumasi dissatisfaction with local land administration and anger towards a particular chief hardly seem to lead to discussions of the desirability of the institution of chieftaincy. For the majority of the people, chieftaincy seems to be a fact.

Chapter 6 specifically deals with the courts and the question of whether they could serve as an alternative channel of resistance. Both their decisions and aspects related to their functioning - such as access, delays and backlogs, and comprehensibility - are analyzed. The 'judicial customary law' is compared with peri-urban practices, and the gap between the two is analyzed and explained by a number of legal and political factors, including the nature of the state legal system, the 
difficulty for a judge to 'know' the applicable rule of local customary law, and the political configuration at local and national levels.

Chapter 7 , the concluding chapter, first summarizes the conclusions from the earlier chapters to compose a comprehensive picture of customary land management in peri-urban Kumasi. As many other countries are also faced with issues of commodification of land, leading to increasing inequity in customary management, the conclusions hold relevance beyond Kumasi or Ghana. This chapter then focuses on a more abstract level, and turns to a discussion of general lessons regarding the study, application, and interpretation of customary law, through which I hope to contribute to theory formulation in this highly relevant field of study. The chapter concludes by answering the dual question of whether problems of access to and security of land in Ghana can be solved within the sphere of customary law and chiefly rule, and to what extent the national legal system can play a role in this process.

\section{Notes}

I Contrasting with this highly positive view on traditional leadership, some literature describes traditional authorities as outdated institutions with no role to play in the modern era of democratic decentralization. For instance in the debate over the role of traditional authorities in post-apartheid South Africa, opponents claimed that "traditional leaders in South Africa have lost all legitimacy because of their involvement in the apartheid government" (Oomen 2002: I82).

2 Land tenure may be defined as the terms and conditions on which land is held, used and transacted (Adams, Sibanda, and Turner i999).

3 When read literally, the definition does not include the realization or certainty of this perceived right. As the words "without hindrance or interference" refer to the perceived right, in this definition a person feels secure of his tenure when he has the perception to have a right to do certain things without hindrance, no matter his perception of hindrances in reality.

4 This should encourage land acquisition by those able to make best use of it. Research, however, shows that the operation of the land market does not appear to work in favor of allocative efficiency (cf. Platteau 2000: 7I).

5 According to Atwood (I990: 664-5) four limiting conditions are likely to substantially reduce the impact of land titling on credit-related increases in agricultural production: (I) major financial market distortions can prevent increased agricultural lending; (2) transaction costs and risks to formal lenders of dealing with small farmer borrowers, even with titled land, may be prohibitive; (3) there may not be an active land market which permits easy transfer of land under collateral; (4) where informal lending predominates, collateral will be of little value.

6 This is elaborately explained in chapter 3 .

7 In the course of this book, I will use 'traditional authorities' and 'traditional leaders' as synonyms. In Ghana, these terms can denote chiefs, heads of families, or tendamba descendants of the pioneer settlers of their respective villages and representatives of the 'earth God' (Kasanga and Kotey 200I: I4). In the Ashanti Region of Ghana, the terms are only used to refer to chiefs. 
8 This is an entrenched provision that can only be amended by parliament after a number of time-consuming and difficult measures have been completed (Ray I998: 6I).

9 The customary community is called 'stool' in reference to the carved wooden stool which is believed to contain the souls of the ancestors and is a traditional symbol of chieftainship.

IO See chapter 2.

II Ohene is the word for king or chief in (Ashanti-)Twi, the indigenous language of the Asante. Within the Ashanti Region each village chief (ohene or odikro) is subordinate to a paramount chief (omanhene), who again is subordinate to the Asantehene.

I2 Whereas some researchers therefore prefer to talk about local land-holding systems and 'socially determined land-use rules' (logiques sociales $d u$ territoire) (Toulmin and Quan 2000c: 99), this book maintains the term 'customary law' following common terminology in Ghana.

I3 For a discussion of the debate over a social scientific concept of law from the I950s through the I970s, see Tamanaha I997: 9I-I28.

I4 In The Netherlands Indies, a huge project was undertaken to ascertain the various customary laws (Dutch: adatrecht), under the direction of the Dutch scholar Van Vollenhoven, who, however, explicitly included the average citizen in his queries, see Van Vollenhoven I9I8.

I5 According to Allott, the restatements were conceived of as a contribution to nation-building and modernization. He explains that there was a large demand for a source of reference on the customary laws, cast into a legal language, and that earlier work by anthropologists failed to meet the criteria for a work usable by the courts (Allott 1969 in Moore I992: 23). See for a discussion of this project Twining I963. Even today, the idea of restatements has not disappeared, see for instance Hinz 2006; Osinbayo and Kalu I991.

i6 Holleman discusses the difficulty of abstracting rules focused upon single interests or actions from decisions in conflict situations involving a plurality of these. Real-life disputes, he observes, often present a much more complex set of issues than can be covered by a single rule, and circumstantial factors can play a role and lead to an outcome which is not strictly in accordance with the rules. Furthermore, the rule-finding exercise is complicated by the fact that conflict resolution often seeks a feasible compromise rather than the enforcement of a rule of conduct (Holleman 1973: 590).

I7 It is a different question whether such created customary law also existed out of the contexts in which it was produced (Von Benda-Beckmann I984b: 29), i.e., to what extent this official customary law influenced local customary law.

I8 See Merry 1992: 363 for an overview of the literature. Some work in this field was already published in the I970s; see for instance Moore I973 and Woodman 1977.

I9 Some notable exceptions are Allott and Woodman 1985; Von Benda-Beckmann I984b; Von Benda-Beckmann and Strijbosch 1985.

20 Property can be seen as sets of rules governing people's rights to access, use and control resources.

2I As the chief's throne is called the stool, the installation and deposition of a chief are called enstoolment and destoolment.

22 SNV is a Netherlands based international development organization. 


\section{How to Combine Tradition and Modernity? Regulating Customary Land Management in Ghana}

Based on Land Use Policy (2008) 25 (2), in press

Janine M. Ubink

Julian F. Quan 



\section{How to combine tradition and modernity? Regulating customary land management in Ghana}

\section{Introduction}

International trends in land policy in developing countries tend to emphasize the importance of recognizing and building on customary tenure systems in order to achieve equitable land management, in the context of poverty reduction (Deininger and Binswanger I999; DFID I999; EU 2004; Toulmin and Quan 2000a; Whitehead and Tsikata 2003; World Bank 2003a). However in Ghana, as in other countries where land transactions have become increasingly monetized in recent years as a result of growing scarcity and increased land values, the equity of customary tenure systems is being questioned. The new developments and the changing values in land that they create result in attempts to redefine land ownership and tenure and contestation of rights to land. These processes have increasingly concentrated control of the economic benefits flowing from land in the hands of traditional chiefs, which has a direct effect on people's livelihoods and creates high tensions in many localities. It is against this background that we want to analyze the role of the government of Ghana in customary land management. This chapter will take the example of peri-urban Ghana to explain how, to what extent, and with what objectives government policy has sought to regulate customary land management by chiefs over time, with special emphasis on the Land Administration Project Ghana (LAP), a long-term program with multi-donor support, which started in 2003 with the objective "to develop a sustainable and well functioning land administration system that is fair, efficient, cost effective, decentralized and that enhances land tenure security" (Ministry of Lands and Forestry 2003: I2). A key issue addressed by this chapter is whether or not the state, through the approach adopted under LAP is able to regulate customary land management in a way that contributes to the avowed objectives of fairness and tenure security.

After a brief discussion of land struggles in peri-urban communities in Ghana, we will discuss the history, the legal mandates, and the actual functioning of a number of governmental institutions involved in customary land management. In addition, we will study the discourse of the government on issues of customary land management and 
chiefly administration in general. We will then turn our attention to the Land Administration Project Ghana, under which the government is piloting the management of customary lands by Customary Land Secretariats (CLSs) under the aegis of traditional authorities. After contextualizing this 'model' within the contemporary international policy trend to recognize and build on customary tenure systems, we go on to compare the aims and discourse of the CLS component of LAP to the actual processes and outcomes so far. The chapter concludes by considering the impact, risks and challenges of state intervention on local struggles for land.

The chapter draws on general literature, policy documents and data collected during field research in peri-urban Kumasi between 20022005 and during policy and project advice on the development and implementation of the LAP on behalf of DFID, from 2002 until the present.

\section{Customary land management and governmental institutions in peri-urban Ghana}

The I992 Constitution vests all customary lands - which constitute approximately $80 \%$ of the land in Ghana (Alden Wily and Hammond 200I: 46-8; Kasanga and Kotey 200I: I3; Larbi, Odoi-Yemo, and Darko I998: I; - in the appropriate stool, skin, or land-owning family on behalf of and in trust for their people, and confirms that such lands be managed according to the fiduciary duty of the traditional authorities towards their people on the basis of customary law, which is recognized as a source of Ghanaian law (articles 267 (I), 36 (8) and II, I992 Constitution). In large parts of southern Ghana, customary land is referred to as stool land in reference to the carved wooden stool which is a traditional symbol of chieftainship and is believed to contain the souls of the ancestors. In the north of Ghana, customary land is defined as skin lands, for here the chiefs sit on a hide. In other areas, such as the Volta Region and Greater Accra, where family heads have jurisdiction over land, we speak of family lands. The Constitution does not however make more specific provision on how customary lands should be managed by traditional authorities, and in practice increasing land values leads to widespread disputes over the powers to allocate rights in customary land and entitlements to the proceeds of these land allocations. For instance, peri-urban areas witness severe struggles between farmers and families, on the one hand, and chiefs on the other over the right to convert farmland into residential land (Abudulai I996, Abudulai 2002; Alden Wily and Hammond 200I; Kasanga et al. I996; Maxwell et al. I998). In agricultural areas similar struggles over 
land and its proceeds can be witnessed (Amanor 1999, Amanor 200I, Amanor 2005; Boni 2006; Firmin-Sellers I995; Fred-Mensah 2000; Hill I963; Lentz 2006; Lund 2006).) describes in detail how new land pressures and commodification have led to contestations and redefinitions of rights to land and labor in the cocoa, oil palm, and forestry sectors of Ghana. Others describe how chiefs have tried to tap a 'gateway to prosperity' by allocating land to migrant pastoralists for substantial payments to the detriment of indigenous farmers (Tonah 2002: 53-57), and point to struggles over the right to lease out land to tomato growers (Berry 1997: I235).

This chapter focuses on peri-urban areas, where traditional authorities are displaying a tendency to adopt landlord-like positions with regard to customary land. Alden Wily and Hammond (2001:44, 69-73) speak of the "curtailment of communal property rights, through a form of feudalization of land relations." Research has shown that chiefs are rapidly converting farmland, in which indigenous community members or families have usufructuary rights, into residential land which they allocate to outsiders through customary leases (Berry 2002a; Gough and Yankson 2000; Kasanga and Woodman 2004; Ubink 2007), and which may or may not be registered with the Lands Commission. Although the Constitution prohibits the sale of customary land and only allows leases, nearly everyone speaks of the 'selling' of land and many people, 'sellers' as well as 'buyers', seem to regard land allocations for residential purposes as definitive transfers. The allocation papers seen during the field research, merely stated that plot $\mathrm{x}$ was allocated to person $y$, neither mentioning the word lease, nor specifying a time period for which the allocation would be valid.

As a result of the allocations, the original land users, with weaker bargaining power, frequently lose their land, their employment, and their income base. Kasanga and Kotey (200I: I8) even claim that "the displacement of poor and marginalized families from their land is a national disease." Traditional authorities display little accountability in the use of monies generated, and most indigenous land users realize little or no benefit from the leasing out of land: they are rarely and then inadequately compensated for land loss; and in most villages only a meager share of the revenue is used for community improvement. Although the new lessees are benefiting from the land conversions, they are also affected by the lack of investment in community facilities, since the areas in which they are building their houses are seldom serviced with electricity, roads, and sewers. Furthermore, the numerous accounts of multiple sales of the same piece of land to different buyers and of sales of alleged residential plots on land unsuitable for residential purposes show the buyer's vulnerable position. In sum the practice of customary land management in peri-urban Ghana differs widely 
from the constitutional provision that puts the interest of the community first.

In addition to the constitutional recognition of customary land under management of traditional authorities, the state has sought over the years to regulate certain aspects of stool land management emphasizing the authority and role of formal land administration agencies over the chiefs, enabling formal registration of customarily acquired rights to provide documentary evidence of tenure, and seeking to generate government revenues from customary land transactions. Successive governments have taken piecemeal measures in the areas of land use planning, land title registration, issuance of formally registered leases, stool land revenue collection, and adjudication of land disputes. We will first turn our attention to the principal agencies involved in these fields, and their mandates, roles, and performance with regard to customary land administration in peri-urban areas.

\section{Office of the Administrator of Stool Lands}

The Constitution provides for an Office of the Administrator of Stool Lands (OASL), which was established by the OASL Act, I994 (Act 48I). This office is responsible for the establishment of a stool land account, and for the collection of all "rents, dues, royalties, revenue or other payments whether in the nature of income or capital from the stool lands" to be paid into this stool land account (article 267 (2), I992 Constitution and section 2, OASL Act, I994 (Act 48I)). Of the revenue accruing from stool lands Io\% shall be paid to the OASL to cover administrative expenses. The other $90 \%$ is to be disbursed in the following proportions: $25 \%$ to the stool for its maintenance; $20 \%$ to the traditional authority; and 55\% to the District Assembly (sections 3 and 8, OASL Act, I994 (Act 48I)). There is no legal requirement that the $25 \%$ of the revenue received by stools is reinvested in the community. Rather, the provisions encourage chiefs to retain the revenue "for the maintenance of the stool in keeping with its status." The use of the $20 \%$ share to the Traditional Council is not specified. According to Alden Wily and Hammond (200I: II8-9) the government in this way "endorses the perception of chiefs of themselves that they are the owners, not merely trustees acting on behalf of the real owners, the community at large."

This provision has a long history pre-dating the current I994 Act. It dates back to the Local Government Ordinance, I95I (Cap 64) and its original purpose was to be the first step in depriving the big chiefs of any role in land management and eventually of ownership and their claims to have the right to collect land 'rents' (Rathbone 2000: 30). Chiefs, therefore, have always resisted handing over 'their' income to 
the OASL. Since in peri-urban areas the conversion from agricultural to residential land accounts for most land revenue, chiefs in these areas centre their resistance on the definition of stool land revenue. They claim that the money they receive for the allocation of land is not purchase money but 'drink money' or 'drinks.' They refer to the custom of bringing some drinks to the chief when acquiring land from him as an acknowledgement of the ownership of the land, to show allegiance towards the chief, and for the customary pouring of libations on the ground to seek the Gods' blessings for the transaction. Whereas a bottle of Schnapps was sufficient in times of land abundance, when land became more valuable a small amount of cash money was added to the Schnapps. In peri-urban Ghana and other areas where land is highly valued and demand is increasing, the amount of cash demanded has gradually risen and now effectively constitutes a market price for the purchase of land leases (Alden Wily and Hammond 200I; Edusah and Simon 200I; Kasanga and Kotey 200I; McCaskie 2000a). The chiefs continue to call this payment 'drinks' and claim that it should therefore not be regarded as 'stool land revenue' in the sense of the OASL Act, and they resist the disclosure of the sums collected. In peri-urban areas the only land revenues that flow to the OASL consist of ground rents - annual governmental fees payable on land leases which are distributed according to the constitutional formula. These rents are small compared to the sums of 'drink money' collected directly by the chiefs in selling land leases. The total amount of ground rent on a ninety-nine year residential lease adds up to about $5 \%$ of the amount of 'drink money.' Because 'drink-money' is portrayed by the chiefs as a ritual device rather than the means of exchange in a sales transaction, it is not collected by the OASL, and so not subject to distribution under the constitutional formula, and thus becomes, effectively part of the income of the chief.

Contrary to Kasanga and Woodman (2004: 185), who for unclear reasons claim that "it has been accepted by everyone concerned that those (sums in 'drinks') do not amount to revenue from stool lands within the meaning of the statute law", most officials interviewed consider that the law meant to include this 'drink money' in the definition of 'stool land revenue' (interviews at the Regional Lands Commission Kumasi, 9 April 2003; Regional OASL Kumasi, 27 June 2003; Ejisu Juaben District Assembly, September 2003). This interpretation seems to square with the very broad definition of stool land revenues provided in the OASL Act, as quoted above. This issue has, however, never been tested in the courts. In the highly personalized society of Ghana, if a case were brought to court by an officer of the OASL, this would not be considered an action on behalf of the government, the ruling political party, or even of the OASL in general, but as a personal action of 
that particular officer. Such an action would surely provoke the wrath of all chiefs. According to the District Chief Executive of Ejisu-Juaben district, "The one who does it will become an enemy of the chiefs," and this can pose serious dangers to the career of the official concerned (interview 9 September 2003). In a number of cases officials have been 'transferred' after standing up to a powerful paramount chief or the Asantehene. According to the District Chief Executive of Ejisu-Juaben district "careless statements by land officials could be dangerous. They may have to pay a price for discourtesy" (interview I2 January 2004). Furthermore, as the Deputy Regional Lands Officer in Kumasi explains, every official is also "subject of a stool and subordinate to the chief" and such an action would be considered as an act of disloyalty towards him (interview 9 April 2003). The one official we encountered who did want to go to court over a sum of 'drink money' of Cedis 3 billion (at the time of sale the equivalent of approximately $€$ 300,000.-) claimed that he was stopped by 'the government', because "the President does not want to pay for such an action" (interview District Chief Executive Ejisu-Juaben district, 9 September 2003).

The lack of an effective political mandate for OASL to exercise the role intended by the Constitution is however only part of the story. A lack of funds, qualified staff, equipment, and vehicles on the one hand, and mismanagement, corruption, and a lack of accountability in OASL's own use of land revenues on the other (Grant 2004: 20-2I, 404I; Kasanga and Kotey 200I: iii; Kasanga and Woodman 2004: I85) also severely hamper the functioning of OASL and affect its legitimacy in the eyes of the people. To date the revenues collected and distributed by the OASL have never been publicly disclosed, and the use of land revenues received by all parties remains unaccounted for and nontransparent. Accusations of irregularities in both spheres are rampant.

\section{Lands Commission}

The Lands Commission (LC) first came into existence following the I969 Constitution, under the Lands Commission Act, I97I (Act 362) and since the advent of the 1992 Constitution operates under the Lands Commission Act, I994 (Act 483). The LC is responsible for the management of all public and vested lands, ${ }^{\mathrm{I}}$ is meant to advise and make recommendations on policies with respect to land use and development, and advise on and assist in the execution of the registration of land titles (section 2, Lands Commission Act, I994 (Act 483)). With regard to stool land, section 4 of Act 483 states: "There shall be no disposition or development of any stool land by any person unless the Regional Lands Commission (...) has certified that the disposition or development is consistent with the development plan drawn up or approved 
by the planning authority" (cf. article 267 (3) of the I992 Constitution). The stated government objectives behind this intervention include (I) the correction of anomalies and problems in the customary sector such as litigation, land disputes, inimical agricultural tenancies etc; (2) the introduction of written records to confer security and promote investment in landed property through the use of registered documents for collateral purposes; and (3) the acceleration of the pace of development by easing land acquisition and documentation procedures (Kasanga I996: 93). This section continues the practice begun in I962 by the Administration of Lands Act, I962 (Act I23) to require the consent of the state to the alienation of stool land (Kasanga and Kotey 200I: 3). Thus if a stool wants to dispose of land, it has to ask the LC for its consent and concurrence.

In practice, consent before an allocation of stool land is never sought. Concurrence after the allocation is sometimes sought, although not by the chief, but by lessees who want to formalize their acquisition, and this is still quite rare. Typically only the more educated people or people with connections in the bureaucracy go through the long, cumbersome and expensive process of formalization. In our survey among 242 people in peri-urban Kumasi, I23 people (50.8\%) answered they had never heard of the LC. Of the II9 $(49.2 \%)$ that had heard of the LC, $65(27 \%)$ were not aware of its tasks and functions. It takes on average between six months and two years to process a document submitted to the Lands Commission (Grant 2004: 95).

The provision of consent and concurrence is not enforced by the LC and therefore does not in practice provide an effective check upon the administration of lands by chiefs. Like the OASL, the LC is hampered by a shortage of trained and motivated staff, lack of basic logistics and support services, poor remuneration and incentive packages, low morale, and endemic corruption (Centre for Democracy and Development 2000: 99-I05; Grant 2004: 2I-2I, 40-4I, 95; Report on the Beneficiary Assessment Survey of the Lands Commission - Ghana, I997, quoted in Hueber and de Veer 200I: I95; Kasanga 2000b: I4; Kasanga and Kotey 200I: iii, 8; cf. interviews with Deputy Regional Lands Officer Kumasi, 9 April 2003; and Technical Director Forestry, Ministry of Lands and Forestry, I5 August 2003). According to Antwi and Adams (2003: 2090), the fact that bureaucrats still insist on the concurrence procedure despite the fact that only a few people seek formal documentation - in their survey among 286 housing land purchasing households in Accra, 76.9\% had not even attempted to seek any formal documentation of their title - can only be explained by the rent seeking opportunities the procedures provide. 


\section{District Assembly}

The Local Government Act, I993 (Act 462) designates District Assemblies (DAs), which have been created since I9 86 but which only received constitutional backing in I992, as the main planning authority charged with the overall development of the district. With regard to land administration, they have legislative powers to make by-laws with respect to building, sanitation, and the environment. The preparation and approval of planning schemes, the granting of building permits, and the enforcement of regulations and sanctions for non-compliance all rest with the DA (Kasanga and Kotey 200I: 9). District level government is dominated by the District Chief Executive, who is the single most powerful local government official. Villages and towns are supposed to draw up a land use planning scheme, with help of the Town and Country Planning Department (TCPD) of the DA. Such a planning scheme designates the uses of the various areas, and shows the boundaries of the individual plots. When a prospective developer applies for a building permit, the TCPD is to check whether the site plan conforms to the planning scheme, and whether the allocation paper is signed by the local chief.

Ammissah et al. (I990: 34, quoted in Hueber and de Veer 2001: I9I) argue that "Since the main aim of the chiefs is to maximize financial returns within the shortest possible time, important land uses such as open spaces, playgrounds, schools, markets, refuse dumps, roads, etc. are sacrificed, in order to augment the supply of building plots. This is a major cause of haphazard and unauthorized development in all statutory planning areas." By means of the land use planning process, the DA could provide some checks on the land administration by chiefs, preventing double allocations, and reserving land for public purposes or even for agriculture. Chiefs can however prevent the drawing up of a planning scheme by withholding their co-operation and not providing any information. "If a chief does not co-operate, you cannot make a planning scheme" (interview director TCPD Ejisu- Juaben district, 27 May 2003, cf. planning officer TCPD Kuntanase district, interview 7 April 2003). According to the TCPD in Ejisu, "It is in the benefit of the chief not to have an approved planning scheme. Therefore the co-operation of chiefs is not very high. Most have their own unapproved planning scheme" (interview with TCPD director, Ejisu-Juaben district, 27 May 2003). In a DFID-sponsored research project 34 of the 37 villages in peri-urban Kumasi possessed village layout plans, but the majority of these plans was prepared without reference to the statutory agencies responsible for planning (DFID 200I: D8, Er3). Unapproved village layout plans, necessary because of the high awareness among buyers/lessees that upon the allocation of land they are supposed to re- 
ceive a site plan and an allocation paper, leave open the possibility of later changes in the plan. Furthermore, although awareness of planning schemes and building permits is increasing, it is still low and most people do not comply with the demand for a building permit, or, also due to the lengthy bureaucratic procedures and the costs involved, the building precedes the formal planning process (Edusah and Simon 200I: section 4.4; Hueber and de Veer 200I: I9I; Toulmin and Longbottom 200I: 29-30). According to the law, the whole process of acquiring a building permit should not take longer than three months. But in 2003 the Ejisu-Juaben district had not seen a meeting of the Planning Committee in over two years (interview Director TCPD Ejisu-Juaben district, 27 May 2003).

Fieldwork showed that the implementation of planning regulation is often lacking, due to a lack of personnel, funds, and logistics (cf. DFID 2004: I2; Hueber and de Veer 200I: I88-9; Kasanga and Kotey 200I: 9-10) and mismanagement and corruption (cf. Kasanga I996: 99; Kasanga and Kotey 200r: iii). And even when violations are found, severe sanctions, such as demolition of unauthorized structures, are avoided (cf. Hueber and de Veer 200I: I9I). Furthermore, when the DA does not have a financial interest, it tries not to get involved in 'local affairs.' For instance, if there is more than one land-owning chief in a village, the TCPD will accept the signature of any one of the chiefs as a valid one. And if there is an agreement within a village that a Plot Allocation Committee - a locally initiated committee consisting of representatives of both the chief and the village that should sign all allocation papers and secure a percentage of the revenue for community development is also to sign the allocation papers, this is considered an internal village affair by the TCPD and they do not check whether such a signature is found on the allocation paper. In this way, the locally agreed upon solution to problems of transparency and distribution of land revenue is not supported by the government.

While the land use planning system could in theory provide a check on chiefly land administration it also provides chiefs with additional powers in local struggles over land. The formalization of the land allocation process by the government, with the signature of the chief as a key element, gives chiefs an extra official card to play, especially those higher up in the hierarchy of traditional authorities. For instance Abudulai (2002: 85) describes how in Tamale the sub-committee of the LC attributes most of the problems in the field of land administration to the lack of documentary evidence. It therefore decided, to bring some order into the system, that divisional chiefs must countersign allocation papers. Similar actions were encountered during fieldwork, at the DA in Ejisu - where it was decided that building permits could be given only when the allocation papers bore the countersignature of the 
paramount chief, so as to prevent future land disputes and litigation, not least involving the paramount chief himself - and at the LC in Kumasi - where despite a court ruling that Kaase stool lands did not fall under the authority of the Asantehene, the LC tried to convince the Kaasehene to have all land allocations countersigned by the Asantehene at the cost of one third of the purchase price (interview Deputy Regional Lands Officer Kumasi, I6 December 2003). A comparable example is found in the distribution of OASL revenues, which are usually paid to the paramount chief, who is supposed to redistribute them in his area according to the constitutional formula. These actions can be explained by a combination of 'administrative efficiency' - dealing with one big man instead of a whole group of people - and attempts to satisfy the person with the greatest troublemaking capacity.

Every electoral area has its own representative at the DA. In many villages, these local assembly members and the members of the Unit Committee (UC) - the lowest level of local government - are public figures, who are widely known, easily accessible, and often most actively involved in development of the community. They are aware of the fact that a lot of money for town development could be generated by stool land allocations. It is therefore not surprising that where chiefs are unwilling to distribute land revenues, UC and DA members are often in direct confrontation with the chief, or lead the public actions against him. Yet while the UC and DA members are a local force to be reckoned with, they are not always backed by the district authorities. The District Chief Executive (DCE) of Ejisu, for instance, while acknowledging the negative effects of chiefly land conversions in his district, went no further than the occasional public statement that chiefs should spend part of the land revenues on community development. When we proposed the idea to back up local Plot Allocation Committees (PACs) by providing building permits only when allocation papers carry the PAC's signature, he rejected the proposal because land revenue would then be spent by the UC and fall outside his own responsibility (interviews District Chief Executive Ejisu-Juaben district, 9 September 2003 and I2 January 2004). More generally, during UC and DA inauguration ceremonies members are often instructed to refrain from interfering in chieftaincy and land matters (interview District Chief Executive Ejisu-Juaben district, 9 September 2003). This is directly in line with the national government's informal 'policy of non-interference' in chieftaincy affairs.

\section{State Courts}

As regards the position of state courts in the field of customary land management, chiefly re-appropriations and conversions of stool lands 
in which community members have a usufructuary interest are not supported by court decisions (Ubink 2002-2004). Although a trend can be discerned in judicial customary law towards more power to the chief as administrator, to ensure sound town planning and more equal distribution of land, this cannot be interpreted to mean that the chief has the power to deal with land as he wishes, without regard for community interests or compensation for farmers. Customary law in the Ghanaian courts rather conveys an image of protection of usufructuary rights against the chiefs' attempts to re-appropriate stool lands for 'development' purposes. First, usufructuary rights are quite secure. Second, the transfer of the usufructuary title does not need the consent of the allodial title holder. This seems even to apply when farmland is transferred for non-farm purposes, such as housing or cemetery plots. And even if a chiefly grant were needed to change land use from agricultural to residential, as was stated in one court case (unreported judgment, no. 5/97 of I3 May I997), it seems that the community member has a right to receive this grant unless overriding communal interests prohibit it. Thirdly, chiefs can be held accountable for the way they use stool land revenues, since there is a "statutory imperative that monies from stool land acquisitions should be lodged in a designated fund" (Owusu v. Agyei [I99I] 2 G.L.R. 493, at 506).

The effect of such court decisions on land practices is, however, limited. Notwithstanding the large number of land cases in the courts, many more land conflicts never reach them, either because of aggrieved parties' lack of access or interest, or because the land conflicts are embedded in 'chieftaincy affairs' for which state courts have no jurisdiction. Moreover court decisions seem to have little effect on land disputes beyond the specific cases on which the court decides. This can be explained by a number of factors. Firstly, people have minimal knowledge of court decisions. During fieldwork people hardly referred to case law or legislation and when they did they often misunderstood it or invented their own provisions. Secondly, the fact that chiefs are regarded in the localities and by the government as authorities in the field of customary law and guardians of stool land offers them a powerful position to define custom in a way that confers and legitimates their powers over land (Chanock I998; Firmin-Sellers I995; Mamdani I996; Oomen 2002). Combined with an erosion of local checks and balances, and a lack of control by the government, it is not surprising that chiefs do not comply with the rules of customary law as set out by the courts that protect the interests of the usufructuary (Ubink 20022004). 


\section{A policy of non-interference}

In the sections above a number of examples display a lack of political willingness to enhance the functioning of Land Sector Agencies (LSAs) such as the OASL and the LC and strengthen their checks on chiefly land management: the unwillingness of the political establishment to bring before the court the question whether 'drink money' is stool land revenue in the sense of the OASL Act; the instructions to DA and UC members to abstain from chieftaincy affairs; and the refusal of the TCPD to check land allocation papers for a signature of the Plot Allocation Committee, where such committees exist. Abudulai (2002: 8I) describes a further example in peri-urban Tamale where "there are apparent sales of plots to wealthier people who 'can put up a building the next day. When that happens, you lose everything, and you have nobody to complain to. The LC will tell you that they solve issues involving land disputes, but not houses already built."

This lack of political support - which results in large part from a deference to chiefly authority and power amongst local government officials - is also mirrored in the policy discourse of the present government. In the media, government officials at all levels regularly and vehemently proclaim that they will not 'meddle in chieftaincy affairs' (see for instance Daily Graphic 25 August 2003: 3; Ghanaian Times 5 August 2003: I, 25 August 2003: 3). According to Boafo-Arthur (2003: I38), President Kufuor himself "has made it clear that the current ruling party is not interested in meddling in chieftaincy affairs." These 'non-interference' statements are sometimes made in reaction to chieftaincy disputes, for which section I5 (I) of the Chieftaincy Act, I97I (Act 370) declares the government has no jurisdiction, but also to express in more general terms that the government will not interfere in chiefly administration such as in the field of land management, which is not dictated by any legislative provision whatsoever. The former Minister of Lands and Forestry, Professor Kasanga, argued that "The state should not attempt to enforce local checks and balances. This should be done by the citizens themselves" (interview 3 December 2005). The bureaucracy, and those charged with directing reform under LAP, tend to adopt a similar perspective. For instance, the former coordinator of LAP at the Ministry of Lands and Forestry, asked in an interview: "Is it the business of the government to address the accountability of chiefs? Within the local system there exists accountability, they can 'destool' a chief, or remove his authority. We do not want to impose accountability on the chiefs, since land is essentially a chief's thing" (interview I9 August 2003). Obviously, such state discourse, together with what we refer to as government's 'policy of non-interference' provides chiefs with 
ample room to manoeuvre, and gives them little reason to fear state intervention in land matters.

The primary basis for the present government's policy of non-interference appears to be a deliberate political alliance with powerful chiefs, coupled with a recognition of chiefs' considerable local political power and influence, and their roles as the key vote-brokers, especially in the rural areas. In addition, the current tendency to fill chieftaincy positions with highly educated professionals blurs the traditional distinction between governmental elite and chiefs, and creates new alliances between these two groups (Ray I992; Bierschenk I993 describes the same phenomenon for Benin). The elite of the party presently in power, the NPP, is especially closely connected to the chiefs. Not only does it have its stronghold in the Ashanti Region, with its powerful chiefs, but president Kufuor himself is through marriage connected to the royal family of the Asantehene. Many members of the current government, up to high levels, are chiefs or royal family members in their hometown.

It should also be noted that rampant irregularities and mismanagement by state institutions in procedures of compulsory acquisition of land do not give the state a strong moral position from which to judge the quality of chiefly land administration (Kotey I996; Daily Graphic, 22 August 2002: I7). Moreover, when the state needs to make new land acquisitions itself, a cooperative relationship with chiefs will be useful.

Chiefs seek to capitalize on the government's current support for chieftaincy by rekindling discussions on certain subjects, such as: the creation of a second chamber of parliament consisting of chiefs; the representation of chiefs on DAs; the referral of all proposals for legislation to the National House of Chiefs for comment as an integral part of the legislative process; the de-vesting and return of former stool lands vested in the president; and an increase of the percentage of stool land revenue to be disbursed by the OASL to the chiefs (see for instance the welcome address of the president of the national House of Chiefs, Odeneho Gyapong Ababio II, at the conference on African traditional leaders, held in Kumasi, on August 3, 2003; and the speech entitled "African traditional systems and the growth of democracy and good governance" given by the paramount chief of Ashanti Asokore, S. K.B. Asante, at the same conference). Chiefly statements and demands on these issues at workshops and policy meetings generally go unchallenged by government representatives.

The overall picture of governmental intervention in customary land throughout most of the post independence period is one of piecemeal attempts to control the management of stool lands, motivated by a wish to rein in the power of the chiefs and enforce the power of the 
state. To do this the government has utilized the laws and institutions for land management and institutions bequeathed by colonialism, further developing these through successive legislation - notably the I992 Constitution which created OASL - but in a fragmentary rather than a comprehensive way.

We have seen that the institutions created and mandated to act as a check on stool land management do not in reality exercise effective control upon the chiefly administration of land due to a combination of factors: a lack of chiefly co-operation with the tasks and duties of LSAs; the LSAs' lack of funds, staff and material, and their problems of mismanagement and corruption; and the difficulties for and unwillingness of officials to challenge chiefly behavior. In this context, the lack of political interest by the present administration to contest the authority of the chiefs by tackling their frequent lack of co-operation in land matters is so pervasive that we can speak of a policy of non-interference. The formal system, however, has also proved incapable of delivering effective land management and security of tenure for the majority of land users.

\section{Land Administration Project}

Against this background of state institutions and discourse, the government of Ghana, after decades of piecemeal legislative and state management measures, formulated its first comprehensive National Land Policy in I999 (Ministry of Lands and Forestry I999) and has embarked, with multi-donor support, upon a Land Administration Project (LAP) intended to reform land institutions and develop land policy so as to provide greater certainty of land rights for ordinary land users and enable greater efficiency and fairness in the land market (Ministry of Lands and Forestry 2003; World Bank 2003a). The underlying problems that LAP was designed to address include the high level of land disputes in the country and cumbersome land administration procedures involving various statutory agencies as well as customary institutions. Recent research in Ghana has shown how difficult it can be for people to obtain documentary evidence of tenure through existing registration mechanisms (Alhassan and Manuh 2005; Kanji et al. 2005). Instead, land transactions take place increasingly through locally witnessed agreements of little legal value, pointing towards the need to incorporate customary systems of documentation within a broader, inclusive land administration system.

Under the LAP the medium to long-term plan is that government should divest itself of responsibility for the management of stool lands. This should proceed incrementally, on the basis of the satisfaction of 
certain criteria, including the setting up of Customary Land Secretariats (CLSs) with appropriate governance structures to assure institutionalized community-level participation and accountability in the use of stool land and the revenue it generates.

The transfer of responsibility for the management of stool lands from LSAs to CLSs in the LAP reflects the problems of delivering tenure security in Ghana through statutory mechanisms, but is also very much in line with the renewed policy emphasis on the importance of recognizing and building on customary tenure systems. This policy trend is, however, subject to critique because customary land rights are the outcomes of negotiations, struggles, disputes, and implicit agreements embedded in social relations of family, kinship and community. These social relations are also inherently unequal, involving power relations between ordinary land users and customary authorities, whose powers and opportunities to redefine customary "law" in their own interests may increase as a result of the formalization of customary tenure systems and institutions over which they exert significant influence and control (Bassett I993: 20-2I; Berry I993; Shipton and Goheen I992). As noted above, the phenomenon of local elites using their power to capture the value of customary land has been identified in a variety of African countries (Chauveau et al. 2006; Juul and Lund 2002a; Lavigne Delville 2000: II3-5; Rose I992; Woodhouse 2003). Also in Ghana, as we have seen, customary authorities frequently do not manage lands in the interests of the holders of customary rights because of the opportunities to generate revenues from sales and transactions in land. Whereas these circumstances do not in our opinion lead necessarily to an outright disqualification of attempts by LAP to transfer responsibility for the management of stool lands to CLSs at the local level (contrary to Whitehead and Tsikata 2003 who do criticize these attempts and argue instead for the replacement of customary land management by more democratic land administration systems under the control of district authorities), they do show that LAP's twin goals of greater certainty for ordinary land users and gains in efficiency and fairness in the land market will only occur if the CLS as an institution is designed in such a way as to promote the land rights of smallholders.

However, from the inception of LAP, it has been government's clear political choice that CLSs should fall under the aegis of traditional authorities rather than opting for more community based approaches to the management of customary land. By placing the customary land secretariats under the aegis of the chiefs LAP ignores the fact that the notion of the "customary" powers and rights of chiefs is loaded with political inventions and endorses the roles that chiefs were accorded in land administration in the colonial period as if this were a timeless 
principle of customary tenure (Amanor 2005: IIO-I). This approach, which was not necessarily the donors' intention, displays a highly skewed interpretation of the trend to recognize and build on customary tenure systems, and enhances the abovementioned risks of elite capture of increasing land revenues to the detriment of ordinary land users. These issues call for a closer look into the design and functioning of CLSs.

\section{CLS Objectives}

The support to customary land management under LAP is intended to strengthen the accountability of customary authorities in land management, in line with constitutional requirements. A program to establish a set of pilot CLSs intends to provide effective land management harmonized with government land agencies and DAs, so as to establish a unified, decentralized public record of land availability, use, and transactions. Research linked to the CLS piloting process was intended to identify improvements to the institutional, policy, and legal framework for customary land administration, including alternative dispute resolution, clarification of the nature of usufructuary rights, and to build on the diverse interests and settings found within Ghana (DFID 2004, CLS Project Memorandum para 5).

The CLS piloting process, linked to debate and learning amongst LSAs, traditional authorities, and DAs, was expected to "bring benefits in terms of: lower costs and simpler methods for confirming claims to land; easier public access to information regarding land use and holdings; improved boundary dispute resolution; and opening up of debate at local level regarding the procedures and norms which should guide land administration" (DFID 2004: para 39). Successful establishment of CLSs has also been anticipated to lead to increased land market transactions and generate additional land revenues for community use. The principal beneficiaries were expected to be the majority of people for whom the current land administration system is effectively inoperable, due to the lack of transparency in the land allocation process, uncertain tenure rights, high costs, and slow, complex bureaucratic procedures (DFID 2004: para 6).

Guaranteeing security of title of small land owners in peri-urban Ghana against powerful chiefs and elders requires a clarification of the nature of usufructuary rights and a protection of these rights against the chiefs' conversion drive (cf. DFID 2004: I9; Ministry of Lands and Forestry 2003: I3; World Bank 2003a: 37). Alden Wily and Hammond (200I: 28, 54) show, however, that during the LAP conception and design process there was no wide and open discussion of the role of chiefs in the administration of stool land - including the tendency of 
chiefs to behave like private landlords - or of the possible checks and balances the state could place on stool land administration. This situation was confirmed in discussion with the DFID rural livelihoods advisor, responsible for moving DFID's support to LAP forward to implementation: "Government doesn't like to include words like accountability, equity and transparency. It wants DFID to tone down the language (of the CLS project design document)" (interview 27 January 2004). Although the lack of open discussion of the role of chiefs can partly be explained by tactical considerations - government's wish not to antagonize the chiefs - it may also be the case that the "policy of non-interference' is currently so pervasive that the problems involved in chiefs' jurisdiction over land and their possible solutions are not open for public discussion.

Although the program is still at too early a stage to provide systematic evidence of the effectiveness of establishing CLSs as a policy intervention, we now consider the emerging evidence regarding the performance, potential, and risks of CLS establishment within a framework of the changing political economic relations and incentives between state, chiefs, and citizenry.

\section{Establishment of Pilot CLSs}

Since the end of 2004, ten pilot CLSs have been established with the object of enhancing the quality of the management of customary land in the area under their jurisdiction. The initial selection was made by the government of one CLS in each of the ten administrative regions of Ghana, so as to provide a representative spread. In addition, a rolling program to identify and establish further pilot CLSs is underway. Of the ten initial pilot CLSs, some were in peri-urban areas, either in major cities such as Accra (Gbawe) and Kumasi (Asantehene's Land Secretariat), or in growing rural towns, such as Kyebi. Others operate in more rural areas, including Wassa Emenfi in the Western Region and Tabiase in the Upper East. These CLSs operate either at stool level, under a chief or paramount chief, or under land-owning families, as in the Greater Accra area, where family heads (the principal elders of lineage groups) are the operative customary authorities with jurisdiction over land.

Gbawe in Greater Accra is generally regarded as the paradigm of CLS good practice (Kasanga and Kotey 200I). It is a fully functioning CLS avant la lettre which was installed by the Gbawe elders prior to LAP, and provided a source of inspiration for the design of the CLS component of LAP. In Gbawe, LAP is working to help consolidate better rent collection systems, improved land and financial records, including published accounts, the provision of secure, registered rights 
to settlers, and the use of land revenues to support community facilities. The existence of an organized land allocation system, which facilitates settlers' access to documented land rights, alongside investments in local infrastructure undertaken by the land owners, are reflected in a high level of demand for residential plots. In 2005 the family elders explained compensation arrangements for farmers who lose agricultural land including the provision of a residential plot, new farm land where available, and entitlement to the proceeds of sale of an additional residential plot (interview with Gbawe Kwatey family elders, II August 2005). The elders noted that a number of displaced farmers were able to use compensation money to invest in more intensive snail, mushroom, and poultry production ventures. Within a year, however, the family head pointed out that no more agricultural land was available, having been lost to residential development including encroachment by neighboring groups, and that Gbawe was "engulfed by Accra." The development of the CLS was cited by the elders as an important factor stimulating the demand for residential land in Gbawe and leading to increased income for the family, as well as resources for investment in community infrastructure. Examples of new community investment underway since the previous year included construction of a police station, a youth employment project, plans to improve sanitation, street lighting and provide public toilet facilities (interview Gbawe Kwatey family head Nii Adom Kwatey and elders, 9 June 2006). The CLS does not, however, record or disclose payments of 'drink money' to the family head as initial down payments on land leases, which, as noted earlier, constitutes the greater part of all land revenues. Despite this sizeable limitation, the Gbawe CLS provides an example of progressive practice in land management as a spontaneous innovation by customary authorities. It must be asked, however, to what extent these innovations are replicable elsewhere under LAP.

In contrast, in other pilot CLSs linked to large and powerful stools, the orientation of traditional authorities has been to use the CLS to consolidate the centralized control of the stool over leasehold transactions. In Kumasi, the capital of Asante Region and Kyebi in Central Region, land secretariats were originally established during the colonial period under the aegis of powerful paramount chiefs, then aligned to the colonial regime. In Kyebi, as in Kumasi, the paramount chief is concerned with reining in local chiefs who transact in land without authorization and without accounting fully to the paramount stool. In both of these cases the paramount chiefs have adopted a system whereby "caretaker chiefs" are responsible to the paramount chief for documenting and authorizing land transactions. The Okyenhene, or Kyebi paramount chief, has sought to control any local land transactions involving commercial investment such as development of plantation 
crops and residential land, including the conversion to new uses of cocoa plantations established by tenant farmers under long standing sharecropping arrangements with local families. The 'drink money' or customary fees collected are then divided between the local chiefs and the Okyenhene. Five per-cent is intended to go to the land user who has sought to dispose of the land or has been required to give it up, but the use to which the money is put by the chiefs is not disclosed (interview Kyebi CLS registrar, Kyebi, I5 August 2005). In Kumasi the Asantehene's Land Secretariat has operated since colonial times a system for registering land transactions in the Kumasi traditional council area, facilitating the stool's centralized collection and management of 'drink money' (alongside a fee element to support the Land Secretariat itself) and the Asantehene's authorization of development plans, thus enabling official registration of leases at the Land Commission by the lessees of residential properties (interview Asantehene's Land Secretariat, Kumasi, I6 August 2005). Here, LAP has been perceived as an opportunity for the traditional authorities to regain the official support and authority over land they formerly enjoyed under British control. In both of these cases the expectations expressed by CLS staff appointed by the chiefs and members of their traditional councils were that government would provide financial, technical and material support to facilitate sales of residential plots to outsiders and improve centralized control of land revenues on behalf of the stool. In Kyebi, the response of the LAP CLS facilitator team was to organize systematic inventories of existing land occupation so as to document the land claims of indigenous land users, tenant farmers and urban settlers. This exercise may in turn provide a basis for the eventual formal registration of land rights and an orderly process of land use change in which the tenure rights of all are respected. In Kumasi, the LAP has not reached an agreement with the traditional authorities yet and no concrete actions have been taken, apart from the initial supply of computer equipment and furniture.

In Wassa Emenfi in Western Region, a predominantly rural area with a high incidence of migrant sharecropping principally for cocoa, where access to land is now becoming more competitive, resulting in tension and disputes between indigenous and migrant groups, government's proposal to establish a CLS was welcomed by the chief. At first the stool's objectives in developing a CLS were not clear, but it soon became evident that the CLS was seen as a way to seek to maximize land availability for profitable disposals and for allocation within their own communities through changing long standing land allocations to strangers. A first proposal of the local CLS coordinator, appointed by the chief, was to use the CLS to convert the secure tenure arrangements of migrants created through long established oral and sometimes written 
sharecropping contracts with land holding families (Alden Wily and Hammond 200I; Amanor and Diderutuah 200I), arguably equivalent to land purchases, into fixed term leaseholds subject to rent collection and eventual discretionary renewal by the CLS (interview with head of Wassa Emenfi CLS, Wassa Akropong, I8 August 2005). LAP project staff - consisting of Ghanaians employed at the Ministry of Lands, Forestry and Mines - disabused the CLS of the legitimacy and legality of such a move. The principles under which LAP operated, with the support of the donors, were to encourage CLSs to document the full range of land claims on the ground, without discrimination, including the established customary rights of both indigenes, which become vulnerable when chiefs sell their land, and tenants, who are vulnerable where indigenous groups try to repossess their land. Following dialogue with the Wassa chief and subchiefs, and a public 'durbar', it was agreed that the CLS should seek to document land rights and support the management of land transactions in the interests of all land users, and the CLS is now registering indigenes' land rights, which should be followed by the registration of migrants. However, as the inventory of land occupation proceeded (a process coordinated by LAP project staff as a pilot CLS activity) LAP enumerators and visiting evaluators were firmly directed away from migrant cocoa farmer settlements by local subchiefs, apparently because of sensitivities surrounding the competing land claims of indigenous and migrant groups.

Elsewhere, pilot CLSs have been inaugurated in areas where customary political and land management systems are less centralized. In Kate Krache in Volta Region a number of land-owning families have come together to establish a CLS. In parts of Upper East, including in peri-urban areas of Bolgatanga, the regional capital, where the customary jurisdiction of traditional land priests (Tindana or Tendamba) over land allocation is frequently now disputed by chiefs, the establishment of CLS has been regarded as a non-starter by the ministry.

\section{Difficulties in CLS Practice}

The process of establishing pilot CLSs under LAP as a wider program to reform land administration in Ghana has raised a number of issues and difficulties that display similarities with problems of customary land management by state institutions discussed earlier. These concern transparency in customary land management, resistance to CLSs by the formal Land Sector Agencies, efficiency problems in project delivery, the position of the state in relation to accountability of chiefs, and hazards inherent in the CLS experiment. After discussing these in turn, we summarize the risks for CLS. 


\section{i. Chiefs and elders prefer opacity}

We have seen that in peri-urban Ghana, the chiefs and elders of certain communities have coalesced into an interest group that is reinterpreting customary land law to support today's opaque, inequitable, and somewhat convoluted system of customary land administration. In this system, chiefs' administrative roles in land rights transactions enable them to appropriate community members' interests for purely economic motives. The CLS objectives of enhancing transparency of land transactions and ensuring accountable and equitable land administration thus run counter to those of this interest group.

Since the present NPP government under Kufour is broadly prochieftaincy in its orientation, and politically committed to the introduction of CLSs, powerful chiefs have rather seen in LAP an opportunity to restore and extend their political and economic control over land (cf. World Bank 2003a: 24). They seek to use CLSs - and the opportunities this provides for centralizing the management of land transactions and the recording and formal documentation of land rights - as instruments for land disposals by the elite by concentrating on facilitating and documenting new land transactions, and failing to document the rights of indigenous land holders.

At the time of writing the processes are incomplete and the effects of improved systems of documentation remain to be seen. In peri-urban areas the CLSs could lead to faster conversion, demarcation and leasing out of farmland, as well as increased revenue generation, with prospects of increased sales revenues for the chiefs. On the other hand better documentation of existing land rights and occupation could be expected to strengthen the ability of both indigenes and tenant farmers to retain their land or to negotiate higher levels of compensation in cases where the traditional authority or land holding group redevelops or disposes of the land. Generally, where there is market demand for land access, customary authorities display tendencies to maximize revenues through leasehold disposals to outsiders - generating both 'drink money' as sales revenue, and regular rental incomes - and through redefining land relations with strangers. The risks are that they are able to use CLSs to facilitate both of these processes. Although comprehensive and inclusive systems of land records provide an important foundation for security of tenure and equity in land relations, the overriding need to gain the support of the chiefs themselves in establishing pilot CLSs has led to restraint in pushing for a clarification of the rights of land users in areas such as Wassa and Kyebi. CLS activities have been unable to address the need to create neutral public arenas for negotiation and settlement of conflicts of interest around land, which was part of the original rationale in developing a CLS program under LAP (DFID 2004). The importance of having officially recognized spaces 
for negotiation of land rights, as a priority function of CLSs, as opposed to administrative secretariats directly controlled by the chief, has also been emphasized by authorities on customary land management in Ghana (Sara Berry personal communication 2004).

\section{ii. Land Sector Agencies resist decentralization}

In addition to the policy perspectives of government in relation to customary land mentioned in section 3, we should also consider the position within the land administration bureaucracy. The behavior of the LSAs in relation to the management of customary land is in line with that predicted by the economic analysis of bureaucracies (Niskanen I975, Niskanen 1994, quoted in Antwi 2006). They operate administrative systems that are portrayed as essentially indispensable to the management of customary land rights transactions and enable them to extract rents in the process (both officially in the form of stipulated fees, and unofficially in the form of bribes to ensure that applications and transactions are actually processed) but which in fact add no value to transactions or services provided. We find evidence of this in the need for the Lands Commission's consent and concurrence of certain customary land transactions (Antwi and Adams 2003: 2095). The CLS objectives of decentralizing land management run counter to the interests of the bureaucracy because they will reduce the involvement and thus the rents and fees generated by LSAs and their officials. Given that a major objective of LAP is to reform and modernize the LSAs themselves, and that their officials are key participants in LAP and the transferal of tasks from LSAs to CLSs, it can thus be expected that the LSA bureaucracy will attempt to employ all sorts of tactics to hinder CLS creation and functioning (cf. Grant 2004: 99). Resistance against the emergence of CLSs as decentralized land management institutions under the aegis of chiefs can however also arise from the conviction that the state has a legitimate role in tackling mismanagement and poor governance of land in the customary sector and that the LSAs were established for this purpose in the interests of Ghana's citizens as a whole. Besides active deliberate resistance, the co-operation of LSA personnel can also be hindered by the earlier described lack of motivated staff, equipment, and personnel. However, while the LSAs' constitutional position has become self sustaining and some of its officials will defend the agencies' roles because they gather revenue from stool land management, allowing them to maintain their position and authority, there are also of course modernizing interests within LSAs. These align more closely with the stated objectives of LAP in recognizing the potential for new arrangements between LSAs and the customary authorities to promote CLSs as decentralized and publicly accountable land management institutions. 


\section{iii. Mainstreaming hinders CLS efficiency}

The implementation of donor-supported programs as an integral aspect of an existing ministry's business - generally referred to as 'mainstreaming' - risks subjecting the program to the motives of politicians and senior officials who may aim to utilize and allocate project resources in such a way as to legitimate their authority and to maximize votes, without necessarily having regard to objectives of equity and/or efficiency (Tullock 1976). Since the LAP is managed directly by the Ministry of Lands, Forestry and Mines (MLFM), the beneficiary institutions, i.e. the ministry and the various LSAs, are expected to reform themselves, build their capacity for new ways of doing business, and moreover, pilot and develop the policy and institutional framework for CLSs as new institutions intended to relieve government of direct responsibility for the management of customary land. The selection of CLS pilot locations has been heavily influenced by a political populist agenda which concedes growing influence to the institutions of chieftaincy across the country. The selection was 'supply driven' by political considerations, including providing visible support to powerful, politically influential chiefs, and ensuring a regional spread. The state also seeks to measure success in terms of numbers (originally aiming to establish fifty pilots in five years) rather than functionality and the ability to serve as lesson learning laboratories. Furthermore, mainstreaming is reliant on a somewhat opaque and cumbersome ministry system of procurement of goods and services (attributed by officials to the requirements of the Procurement Act, but which at the same time maintains control of key managers over procurement and scope for political influence over the award of contracts and staff selection) involving multiple levels of approval, which delays decision making and hinders the activities of CLS field officers charged with the implementation of the project.

\section{iv. The state and the question of chiefly accountability}

Based on past history of government interventions, chiefs were initially suspicious of government's proposals to introduce CLSs and had to be assured that CLSs would not compromise the policy of non-interference. "At first, chiefs were afraid that the government would take away their land," explains the World Bank's natural resource management specialist. However, these fears were soon dispelled. "We reacted quickly and got their support. Now they like the project because we do not prescribe anything" (interview natural resource management specialist, World Bank, I9 January 2004). At the inception of LAP, and prior to recruitment of dedicated CLS development personnel, the government presented the idea of pilot CLSs to traditional leaders as packages of equipment and technical support to help resource and im- 
prove efficiency in existing customary land management practices. According to DFID's rural livelihoods advisor, in conveying this message, "LAPU (the LAP Unit at the MLFM) has done more wrong than right in its first year of the CLS project. Chiefs are now asking for their money and package" leading to expectations that government and donors will assume responsibility for meeting CLS salary costs and other recurrent expenditures (interview, 27 January 2004).

LAP documents make a clear commitment to enhancing the accountability and transparency of customary land management through CLSs and the participation of land using communities in the CLS development process. This includes efforts to clarify the nature of usufructuary rights, and provisions for legislative reform to clarify the strength of the rights held by different land users, including both members of stools and land holding families, and their lessees and tenants. The usufructuary rights of members of land holding groups are often referred to as 'customary freeholds.' However, the issue of whether or not customary rights held in perpetuity by members of the stools can be considered equivalent to freehold rights, and at what levels these rights might exist - stool, family, lineage, household, or individual - are widely debated in Ghana and subject to differing interpretations. Through the CLS piloting process, LAP staff also have opportunities to draw up, discuss, and introduce Memoranda of Understanding (MoUs) between the ministry and the chiefs, setting out the responsibilities on both sides and working towards the establishment of a wider regulatory framework for CLSs, which would be informed by the piloting process. However, government has not as yet made efforts to clarify the nature of usufructuary rights, or to adapt model MoUs drafted by the CLS facilitation team and have them signed as formal agreements between the Ministry and the chiefs to govern the operations of the pilot CLS. LAP has even advised against the use, in draft MoUs, of language which might be interpreted by the chiefs as imposing requirements of accountability, disclosure of revenues, or significant commitments of stool resources to supporting CLSs. Government has not so far introduced a clear policy on the purpose and responsibilities attached to CLSs, and the parameters for establishment of each pilot CLS remain somewhat ad hoc. What is clear is that, in order to secure the votes that the chiefs command, government in the short to medium term is unlikely to risk antagonizing the chiefs by requiring public disclosure of land revenues and accountability in their use, in line with government's broader policy of non-interference in chiefly affairs. According to DFID's rural livelihoods adviser, "Land reform is not the sort of thing you'd sensibly pursue, with the 2008 elections in your mind" (interview, I4 September 2005). He also pointed out that LAP project staff have found it difficult to speak up when not 
backed up by the minister. For instance at a meeting with the National House of Chiefs ${ }^{2}$ in 2005 , the LAP project staff was reluctant to present the content of a comprehensive expert report on the need for legislative reform (Kotey, Dowuona-Hammond, and Atuguba 2004) and to discuss their own views or how they expected to make use of the report. They simply handed it over: "As long as that doesn't change, traditional authorities will take advantage of LAP" (id.). Recognizing the institutional and political difficulties in establishing CLSs, the customary land management objectives of LAP constitute "a high risk intervention with a modest chance for success, to put it mildly" (interview rural livelihoods advisor, DFID, 27 January 2004).

LAP includes provisions for strengthening civil society participation, and advocacy in relation to land management, but this has been slow to develop, and at the time of writing remains problematic. On the one hand Ghanaian civil society has limited pre-existing capacity and virtually none in place for the engagement and advocacy on land. It is difficult to induce this by external intervention because of widespread deference to chiefly authority and a history of cooption of civil society by both chieftaincy institutions and political parties (Amanor 200I: II2-3). On the other hand MLFM has been reluctant to give up control over funds intended to support civil society partners or to commission services from them, and there is a lack of alternative mechanisms such as independent trusts or programs capable of managing funds to meet donors' and government's requirements.

In general, it could thus be said that until now, the government has been reluctant to impose requirements of equity and accountability or otherwise interfere with the management and disposal of land by chiefs.

\section{v. Moral hazards, ownership and CLS sustainability}

LAP is faced with the moral hazard that traditional authorities, after having been supported with equipment and necessary training for the efficient operation of CLSs, employ the supplied resources with less care, diligence, and efficiency than they would have done if they had spent their own monies to acquire the resources (Antwi 2006: 5). Requests for the repair of equipment (for instance from the pilots at Wassa and Tamale) imply a perception of CLSs as a state or donor initiative, rather than as an entity owned by the customary authority or the community. For some CLSs there may be general problems of affordability of or access to technical support services, in which case the appropriateness of a pre-conceived package of CLS equipment must be questioned.

Inability or unwillingness of customary authorities to pay CLS staff salaries is emerging as a common constraint to CLS development and 
appears to be a key indicator of (a lack of) CLS ownership and sustainability. In cases where land market activity and land revenues are low, the establishment of a full-blown CLS may not be justified or affordable; on the other hand, in cases where the land market is more active, it is clear that chiefs are also not yet sufficiently convinced of the value of a CLS to commit additional resources. In the Asantehene's CLS in Kumasi, which does pay salaries, LAP has faced repeated demands for funds to refurbish the building, located within the Asantehene's palace and to provide the resources that will allow it conduct business as usual, as directed by the Asantehene. In the absence of expected higher levels of material and financial support from LAP, Kumasi CLS staff have refused to collaborate with the LAP team in discussing how they might help to improve the equity and efficiency of customary land administration (interview Asantehene's Land Secretariat, Kumasi, I6 August 2005). It can be concluded that the sense of ownership amongst the chiefs of the model of CLSs so far developed under LAP remains limited, with CLSs perceived as an imposition of government, which, though they are not wholly unwelcome, are not fully understood, generating concerns expressed by chiefs about how the staffing, management, and equipment costs of CLSs are to be met.

We have seen that one of the expected benefits of CLSs is to use the secretariat as the starting point for comprehensive exercises in documenting existing land holdings, which provides both a basis for the incremental strengthening and formalization of rights and a source of evidence to avert or resolve disputes over land rights within a CLS catchment. As discussed earlier, this is being done in two CLS pilots, Wassa and Kyebi, initiated by the LAP and organized with project resources rather than by the customary land owners themselves. However it is not clear how these initiatives could be replicated elsewhere and it is unlikely that other CLSs would be able to mobilize the resources (transport, survey management, additional computer equipment, and competent personnel) to develop and manage land user databases without either sustained outside support or full commitment by the stools. In any event it is quite likely that the costs of this sort of exercise would exceed available resources, as well as the likely financial benefits even if the chiefs were willing. Moreover this sort of data collection is arguably a public land administration function which should somehow be resourced by the state. Thus there is a risk that unless a clear relationship and basis for cost sharing for CLSs is established between the state and traditional authorities, CLSs will come to depend permanently on ad hoc donor and government support to collect and manage data. This could lead to a situation in which project resources are inefficiently employed and the pilot CLSs never grow beyond their embryonic stage. 


\section{The Risks to Equity of CLS}

Well functioning CLSs based on the present model could be expected to have some benefits for some groups in peri-urban areas, notably the chiefs and land-owning families themselves and those wishing to settle and develop businesses in expanding residential peri-urban areas who can afford to purchase leases. A clearer, more widely used and more efficient land allocation and registration system, based on the Gbawe model, which is decentralized and accessible to users, would lower transaction costs by making buying and selling land easier and would also reduce conflict. However, there could be serious problems of equity, in which members of indigenous land holding groups, and others who had obtained land through previous oral contracts and informal arrangements, remain vulnerable to arbitrary dispossession, with inadequate or non-existent compensation.

CLSs which strengthen the political and economic weight of the traditional authorities by providing formal recognition of their powers to administer and allocate land (cf. DFID 2004: 26) would sanction their ability to generate substantial profits from the disposal of land, over which the original land users exert legitimate claims. If government does not clearly spread the message of the legitimacy of communal interests in land, as recognized by the courts, and the need for the accountability of the chiefs, which is stated in the Constitution, then it would provide de facto support for chiefs' claims that they can convert land in which community members have usufructuary land rights.

In conclusion, the risks to this CLS model are that traditional authorities may use enhanced and equipped CLSs to further the tendencies of dispossessing community members of lands (cf. Antwi 2006: 5). This will have the perverse effect that people are disenfranchised rather than empowered. The present approach to the management of customary land in Ghana therefore does not appear capable of combining tradition and modernity in an equitable way in the interests of all citizens, an objective espoused by LAP.

\section{Some conclusions on the influence of the government of Ghana on customary land tenure in peri-urban areas}

In this chapter we have analyzed the influence of the government of Ghana on customary land tenure. We have focused primarily on periurban Ghana, where traditional authorities are assuming the right to convert farmland, cultivated by community members, into residential land which they allocate to outsiders. We have seen that various governmental institutions, despite their mandate, in practice do not act as 
a check upon the functioning of traditional authorities. The OASL does not control the great part of all peri-urban land revenues, as a result of the fiction of 'drink money.' The LC is only rarely requested for concurrence, and then not by chiefs seeking to develop and dispose of land, but by lessees who want to acquire a formal lease. The DAs' check on chiefly land administration by means of the planning process is severely hampered by uncooperative chiefs, ignorance of planning requirements, and by mismanagement, corruption, and the lack of adequate personnel and logistics for implementation. Where local representatives of the DA and UC stand up against chiefly maladministration of land, they are not backed up politically. The planning process actually enhances the position of chiefs to a certain extent, since building permits are only issued when a land allocation paper contains the signature of the chief. The interpretation of customary law by the courts shows a similar trend towards recognition of the power of the chief as administrator, although this does not mean that the chief has the power to deal with land as he wishes, without regard for community interests or compensation for farmers. Although Ghanaian courts do protect the interests of individual land users against chiefs' attempts to re-appropriate stool lands for 'development' purposes, the effect of such court decisions on land practices is limited.

All in all, governmental institutions do not provide effective checks on land management by chiefs in peri-urban Ghana, due to a combination of factors: a lack of chiefly co-operation; limited challenges to chiefs from LSA officials; a present lack of political support for administrative controls on land management by chiefs; LSAs' lack of funds, staff, and material; and their problems of mismanagement and corruption. The lack of political support, mirrored in state discourse, constitutes a 'policy of non-interference' with regard to matters involving chiefs. This policy also influences the execution of the CLS component of the LAP, an explicit attempt to improve customary land management, but one which runs up against problems of chiefs' vested interests in land disposals, misunderstandings, lack of resources, and an absence of public debate on the type of institutions required for the governance of customary lands. The above shows that the LAP's starting point, that LSAs do not function effectively, is justified. Nevertheless, the transfer of their powers in customary land management to CLSs under the aegis of traditional authorities is disenfranchising ordinary land users. Although there are isolated cases of spontaneous good practice (such as Gbawe) and some chiefs express goodwill towards CLSs as a state and donor led innovation, land holding community members and land users themselves currently lack forms of organization capable of counterbalancing the power of chieftaincy, and there is a significant risk that government will not commit to building equitable and ac- 
countable arrangements for the management of customary land. The empowerment of chiefs through the resourcing of CLSs without developing appropriate checks and balances brings significant risks in that powerful customary leaders may utilize CLSs to consolidate their political control over land, with negative consequences for poorer, less powerful land users.

The early failures of the chiefs to take responsibility and ownership of the CLSs, expectations that the state should resource them, together with their preferences that CLSs prioritize particular functions linked to generation of revenue for the stools, as well as the reluctance to see CLSs established as fully accountable institutions, suggest that an alternative approach to that adopted so far by LAP is likely needed. Simply subsidizing traditional authorities with material and technical support for CLSs and hoping for the best will not provide the basis of a sustainable approach. Any substantial change to the CLS experiment will, however, rely on clearly articulated political will and commitment to craft a partnership between state, traditional authorities and land users if it is to establish an effective framework for the governance of customary land in Ghana. Without significant political change, the possibilities of enhancing the certainty of land rights for ordinary land users - one of the main objectives of the LAP - are extremely limited.

If such political will were to exist, a road could be taken towards the creation of tripartite institutions that involve LSAs, chiefs, and local people. Such institutions would need to be differentiated according to local circumstances. The relationship between land users and traditional authorities, for instance, differs widely between a locality with strongly centralized land management under the auspices of a paramount chief and a locality where land is managed by a head of family. Chiefs can perhaps be softened and persuaded to such a new approach by governmental concessions in related areas, such as the return of or payment of compensation for vested lands, a full disclosure of the collection and allocation of stool revenues by OASL, and the establishment of a new framework for the division of powers and responsibilities in local affairs between chiefs and the District Assemblies (Quan and Antwi 2008, forthcoming). Designing the governance arrangement for such customary land management institutions, and determining how different stakeholders would be empowered and their interests represented, presents a considerable challenge, one which LAP has yet to consider. Could a role be envisaged for the courts, for the Commission on Human Rights and Administrative Justice, or an ombudsman? Whatever approach is adopted, changes need to be made. If government were to press ahead with the creation of CLSs as unregulated estate agencies run by chiefs and land holding families, the CLS experiment in improving governance and equity in land matters will be a failure. 


\section{Notes}

I Land ownership in Ghana is classified into two categories: private lands and public lands. Around twenty percent of the land area is public land (see article 257 of the I992 Constitution), which falls into two main categories: land which has been compulsorily acquired for a public purpose or in the public interest under the State Lands Act, I962 (Act I25) or other relevant statute; and land which has been vested in the president, in trust for the landholding community under the Administration of Lands Act, I962 (Act I23). The rest of the land area in Ghana is private land, which consists, besides a small amount of common law interests, primarily of estates in customary communal ownership (Alden Wily and Hammond 2001: 46-48). According to Kasanga and Kotey the customary sector holds 80 to 90 percent of all undeveloped land in Ghana (Kasanga and Kotey 200I: I3).

2 In Ghana, there is an elaborate system of Houses of Chiefs. This includes several hundred traditional councils, each of which elects members to one of ten Regional Houses of Chiefs, each of which sends five members to a National House of Chiefs. Its administrative staff is provided by the Government of Ghana, which also maintains a Chieftaincy Division in the President's Office for liaison purposes. Some of the main functions of the National House of Chiefs are to advise on matters affecting chieftaincy and to adjudicate appeal cases in chieftaincy matters (see articles 272, 273 of the I992 Constitution). 


\section{Land Policies for Tenure Security or the Reality of Customary Land Management in Peri-Urban Ghana}

Based on Journal of African Law (2007) 51 (2), 215-248 and W. Zips and M. Weilenmann (eds.), The Governance of Legal Pluralism, Münster: Lit Verlag, 2008, forthcoming ${ }^{2}$

Janine M. Ubink 



\section{Land policies for tenure security or the reality of customary land management in peri-urban Ghana}

\section{Introduction}

The area around Kumasi, the capital of Ghana's Ashanti Region, displays a mounting pressure on land due to strong urbanization and population growth. ${ }^{3}$ In response to the rising demand for mainly residential land, the chiefs are rapidly leasing communal land to outsiders for valuable consideration. This is leading to increasing tenure insecurity among community members. They lose their agricultural land, which renders them immediately or ultimately landless, and they are no longer able to grow their own food and generate income by selling the surplus at the market. Most of the (often poorly educated) farmers are becoming unemployed or are resorting to petty trade, as food prices rise in these communities, which in turn leads to a higher cost of living. Peri-urban poverty rises dramatically and the old parts of the villages turn into shantytowns. Furthermore, local people cannot compete for a plot of land with outsiders employed in the formal sector, which makes it hard for them to find land for residential purposes in their own village. ${ }^{4}$

Despite the fact that the chiefs are customarily and constitutionally obliged to administer the land in the interests of the whole community, they generally display little accountability for any money generated and most indigenous community members are seeing little or no benefit from the leases. The customary land users are only rarely - and then very inadequately - compensated for the loss of their farmland, and in most villages only a meager part of the money is used for community development. Although the new lessees are benefiting from the land conversions, they are also affected by the lack of community improvement, since the areas they are building their houses in are seldom serviced with electricity, roads and sewers. Furthermore, the numerous accounts of multiple sales of the same piece of land to different buyers show the buyer's vulnerable position.

The conversion of farmland to residential land and the effects on farmers' tenure security and livelihood described above for peri-urban Kumasi $^{5}$ have also been documented for the outskirts of a number of other major Ghanaian towns, such as Accra (Gough and Yankson 
2000; Kasanga et al. I996; Maxwell et al. I998; NRI (Natural Resources Institute) and UST (University of Science and Technology) I997: 28-30, Di3-I4; Wehrmann 2002), 6 Tamale (Abudulai 2002), and Wa (Hammond 2005: I8). According to Kasanga and Kotey evidence from all ten regional capitals "confirms that the displacement of poor and marginalized families from their land is a national disease" (Kasanga and Kotey 200I: I8). Alden Wily and Hammond describe the "curtailment of communal property rights, through a form of feudalization of land relations" as a problem occurring in the entire peri-urban arena (Alden Wily and Hammond 200I: 44, 69-73). ${ }^{7}$ In contrast with this crisis in customary land administration, current international land policy witnesses a renewed interest in customary tenure systems and Ghana's current land policy resonates with this international trend. This chapter aims to answer two questions: how can this crisis in customary land administration be explained? And how can the knowledge of this crisis be translated into national and international land policy?

With regard to the first question, the lack of tenure security for periurban farmers and the problematic effects on farmers' livelihoods are well-known. However, there has been little in-depth research into the struggles and negotiations over customary land tenure taking place in the local arena. To acquire an insight into these processes, this chapter studies the practices of land administration in nine villages on the fringes of Kumasi. ${ }^{8}$ This will lead to a conclusion on the main factors that explain how Ashanti chiefs are able to profit from communal land: the erosion of traditional checks and balances; the government's current 'policy of non-interference' towards chiefs; and the fact that local land tenure is characterized by a leading position for chiefs and a prominence of customary law. Since these three factors are found to operate not only in other areas of Ghana, but also in other African countries, it is likely that the lessons from Ghana can be generalized, at least for areas with a high demand for land.

This brings us to the second question. How can knowledge of this crisis be translated into national and international land policy? So far, information concerning inequity and problems of access and security does not seem to have had much effect on present-day land policies. This can partly be explained by the fact that there exist two quite separate schools of land research. The first school focuses largely on economic issues such as investment and productivity and often compares these two issues under state programs and customary systems of land tenure (Acock 1962; Atwood I990; Ault and Rutman I979; Bruce and Migot-Adholla I994; Feder and Noronha 1987; Gerschenberg 1971; North I990; Platteau 2000; Podedworny 197I; Sjaastad and Bromley I997; Yudelman 1964). The second school studies land management and land tenure mainly as social processes. These researchers mostly 
undertake long-term in-depth anthropological field research into land administration and the social systems in which this takes place. They focus on the local arena, emphasizing the ambiguity and pervasive negotiability of customary tenure systems (Berry 200I; Fred-Mensah 2000; Moore I986; Rose I992). Whereas the first school has been in constant dialogue with national and international policy makers, the second school originally shunned from making policy recommendations (Toulmin, Lavigne Delville, and Traoré 2002b: 23). This second school of research, with its thorough analysis of the functioning of tenure systems, is, however, indispensable for well-informed policy making. Some $\mathrm{m}$ ore recent literature has, fortunately, tried to bridge the gap by studying the constitutive relationships between negotiations for land at the local level and legislation, policy and discourse at the national and even international level (Amanor I999, 200I; Benjaminsen and Lund 2003b; Berry I997; Downs and Reyna I988; Juul and Lund 2002a; Lund 2000; Moore I998; Shipton and Goheen I992; Toulmin and Quan 2000c). This linking of local and supra-local arenas facilitates the daunting task of 'translating' research data into policy documents. The present research aims to contribute to this literature.

Before describing the case-study of peri-urban Kumasi, this chapter starts in section two with a description of the wider debates in policy and research circles with regard to the issues of tenure security, investment and productivity. This will show that the policy pendulum has swung from a preference for state-controlled programs of individualization of land to a renewed interest in customary tenure systems. Section three briefly introduces Ghanaian national law and Ashanti customary law with regard to land administration and the role of chiefs therein. In section four the chapter shows how Ashanti chiefs try to legitimate their actions with an appeal to customary law; how community members try to resist their chiefs' actions and claims; and that the success of this resistance is often very limited through a combination of a lack of traditional checks and balances and the government's present 'policy of non-interference' with regard to chieftaincy matters. The chapter ends in section five with two conclusions: first, on the factors that explain the current crisis in land administration, demonstrating the mutually constitutive relationships between government and chiefs and between customary law and state law; and second, on why this information on the crisis in land administration does not seem to feed into the policy level. This chapter is based on data gathered through participant observation, semi-structured interviews and a survey, during twelve months of fieldwork conducted between 2003 and 2005 . 


\section{Land tenure systems, security and productivity}

\section{Customary Law or State Law}

For many years now scholars and policy makers have disputed whether security of tenure, ${ }^{9}$ investment and agricultural production can best be promoted through indigenous customary land use arrangements or through state-imposed tenure aimed at creating private property through titling and registration programs. ${ }^{\text {IO }}$ During the decades after decolonization, the deplorable state of agriculture in Sub-Saharan Africa kindled debate over the suitability of customary land use practices for an agriculture that is capitalizing and adopting new technologies to increase productivity. Many authors agreed that customary land tenure was failing to provide the farmer with security of tenure and therefore impeded agricultural progress (Acock I962; Feder and Noronha I987; Podedworny I97I; Yudelman I964). ${ }^{\text {II }}$ Resonating with the broader global agenda to withdraw government from economic life, land reform has been promoted that aimed at creating individual property rights to increase agricultural productivity (Demsetz I967; Feder et al. I988; North I990; USAID I986; World Bank I975; cf. Platteau I996; Toulmin and Quan 2000a: 7-8). This was, however, done without rigorous empirical analyses of the validity of the hypothesized causal relationship between individual rights in land and improved tenure security and agricultural outputs in the African context (Atwood I990: 664-5; Migot-Adholla and Bruce I994: 2).

Let us start with the causal relationship between tenure security on the one hand and investments and yields on the other. Research shows that this causality depends on the fulfillment of a number of conditions. First, enhanced tenure security will only lead to higher investment demands when the farmer has knowledge of and access to inputs, viable technologies and advice, and when investments are profitable and investment returns not too risky. Second, even when demand for investment is enhanced, the absence of household labor and financial resources may prevent farmers from exercising this demand. Small farmers, even when they have a clear and secure title to their land can still have extreme difficulties in acquiring a loan. Third, land improvements do not necessarily increase yields. Households may target their investments towards reducing yield variance rather than increasing mean yield, or they may prefer leisure or pursue off-farm opportunities (Atwood I990: 664-5; DFID I999: 9; Shipton and Goheen I992: 3I78).

Now that we have seen that tenure security is a necessary but not a sufficient condition to enhance investment and production, the following paragraphs concentrate on the link between private property on the one hand and tenure security, investment and production on the other. 
Whereas Feder et al. and Li et al. argue on the basis of data from Thailand and China that private property increased security, investment and productivity, this link is not supported by African evidence (Feder et al. I988; Li, Rozelle, and Brandt I998; Migot-Adholla and Bruce I994: 2). ${ }^{\text {I2 }}$ In several countries in Africa no significant relationship was found between tenure regime on the one hand and security, credit use, and productivity on the other, suggesting that factors other than land tenure are more constraining for agricultural development (Atwood I990; Bruce, Migot-Adholla, and Atherton I994; DFID I999: II; Gerschenberg I97I: 60; Migot-Adholla et al. I993: 269; Ouédraogo et al. I996). Bruce et al. found no clear correlation between titling and the danger of loss of access to the land, unless households had better quality of land or good water access - the land most likely to have been sought after by others - or unless the titles were needed to provide greater protection against the arbitrariness on the part of the state itself (Bruce, Migot-Adholla, and Atherton I994: 257-9; cf. DFID I999: 8). When security was measured by the number of land disputes, the results were mixed: state-led individualization programs in some countries caused a decrease of disputes, in others an increase (Bruce, Migot-Adholla, and Atherton I994: 257). According to Sjaastad and Bromley, investment is often necessary to obtain security instead of the other way round (Sjaastad and Bromley I997; cf. Quisumbing et al. 200I). Platteau concludes from this that the incentive to invest might be higher under a less secure customary tenure system than under a freehold regime (Platteau 2000: 58).

Empirical evidence from several African case studies shows that land titling and registration of private property can create rather than reduce uncertainty and conflict over land rights (Atwood I990: 663). Unsuccessful attempts to substitute state titles for customary entitlements and according to Cousins not one attempt has been fully successful may even reduce security by creating normative confusion, of which the powerful may take advantage (Cousins 2000: I7I; cf. Atwood I990: 663-5; Bruce, Migot-Adholla, and Atherton I994: 260; Coldham I979: 6I8-9; DFID I999: II). Several ex post evaluations of the state-imposed tenure conversion program in Kenya have observed that individualization has led to land concentration, increased marginalization and landlessness as people in positions of economic and political power take advantage of the less powerful, deepening tenure insecurity instead of lessening it (Coldham I979; Okoth-Ogendo I976; Quan 2000: 35-7). When talking about increasing tenure security, one should thus always ask whose security is increasing. Increasing tenure security for one usually correlates with decreasing tenure security for another, since claims of subordinate right-holders to conditional, partial or common access tend to be neglected in individual titling programs (Atwood 
I990: 66I; Cotula, Toulmin, and Hesse 2004: 2; Lund 2000: I6; Shipton and Goheen I992: 316).

This summary of the literature shows that evidence of the links between private property and tenure security is far from conclusive. On account of this conclusion and of mounting evidence of the high economic and social costs and negative consequences for the poor of individual land registration and titling programs, "the old idea - that land titling programs linked to the development of free land markets are a necessary condition for African rural development - is now dead" (DFID I999: 37; Fitzpatrick 2005; Platteau I996: 74; Platteau 2000; Toulmin and Quan 2000a: 2, I3-I5). Policy makers no longer regard land titling as the panacea for land tenure in Africa. On the contrary, communal forms of tenure are regarded more favorably as mechanisms for land access and employment creation (Deininger and Binswanger I999; DFID I999: 7; Quan 2000: 38; World Bank 2003b: 53). ${ }^{13}$ There is now widespread recognition that land policy must start from existing realities and systems. ${ }^{\text {I4 }}$ A critical voice comes from Heller, who warns for the emergence of 'anticommons property.' In his opinion, this will occur when governments model their property rights regimes on customary tenure systems in which multiple owners of land are each endowed with the right to exclude others and can therefore prevent the use or transfer of the land. This will hinder the optimal utilization of the land and create a 'tragedy of the anticommons' (Heller 1998). ${ }^{\mathrm{I}}$ Other authors claim that the social security function of land and access to community mechanisms for coping with hard times remain paramount, and that compliance with community mores therefore continues to be of great importance (Benjaminsen and Lund 2003a: 7; Bruce, Migot-Adholla, and Atherton 1994: 259; Lund 2000: I8; Mathieu, Zongo, and Paré 2003: I27). Bruce et al. conclude from that that national legislation of tenure reform has a limited capacity to change behavior. They recommend that programs of compulsory and systematic titling and registration should be confined to areas in which land has become valuable and is the subject of intense competition and disputes, and the customary tenure system is unable to cope with the conflicts (Bruce, Migot-Adholla, and Atherton I994: 262).

In sum, the policy shift towards a renewed interest in customary tenure systems seems to a large extent inspired by two factors. The first factor is disappointment with state programs of titling and registration, leading to a renewed interest in alternative land tenure systems out of a kind of 'default reasoning.' The second factor is the practical necessity to start from existing realities and systems. Somewhat surprisingly, the policy shift seems hardly informed by in-depth knowledge of the functioning of customary land tenure systems. 


\section{Research on Customary Land Tenure}

A comparable reproach with regard to the lacking of a critical assessment of customary land tenure can be made against a number of scholars that seem to base their writings on "hypothetical models of how land was managed in traditional systems" (Amanor 2001: 63). Their studies emphasize that customary tenure regimes embody important principles concerned with equity, social security and the maintenance of ecological balance, and that they are built on core values of processes of negotiation and consensus-building and contain checks and balances to control abuse of authority by traditional leaders (Field-Juma I996; Kasanga I994: 7-8; Kasanga 2002; Okoth-Ogendo I994: 23-4; Platteau 2000: 72). Kasanga, for instance, speaks of "the egalitarian tenurial systems" and claims that "customary land law offers the best security of tenure to individuals, families and local communities" and that "there are reasonable checks at the local level on almost everybody" (Kasanga 2002: 29, 36). And Platteau, although claiming not to fall "into the snare of romanticism", but rather displaying "a pragmatic attitude grounded in a realistic assessment of Sub Saharan Africa's present predicament", makes the following statement about informal village practices with regard to land: “(...) considerations of social security and equity usually dominate pure efficiency concerns (...) customary systems continue to generate a remarkable degree of consensus, in particular on the norms and values justifying land claims" (Platteau 2000: 72).

These studies tend to assert the positive attributes of customary law as ideal principles rather than show them to operate in practice. According to Amanor and Lavigne Delville, these studies fall back on a pristine African custom, portrayed against a modern corrupt and inequitable state (Amanor I999: Io; Lavigne Delville 2000: II4-5). It is widely acknowledged that a romantic, idealized version of customary law often exists parallel with the practically applied version of customary law. Researchers have been struggling with these differing versions ever since the colonial period (Chanock I998; Comaroff and Roberts I981; Holleman I973; Mamdani I996). In interviews, local people especially traditional authorities such as chiefs and elders - often present idealized notions of egalitarian and sustainable customary law, instead of the actual practiced customary law, which may differ from case to case. To study 'locally practiced customary law' thus requires thorough local fieldwork.

Fortunately, there is a well-researched body of literature that does in fact describe 'lived customary law.' Since Demsetz's seminal ig67 paper on the evolution of property rights regimes (Demsetz I967), a number of studies has observed how, over time, customary tenure sys- 
tems experience spontaneous simplification and individualization of rights whereby households increasingly acquire broader rights of exclusion and transfer as population pressure and levels of commercialization increase (Atwood I990: 66I; Ault and Rutman I979; Bassett I993; Benjaminsen and Lund 2003a: 8-9; Benjaminsen and Sjaastad 2003: I47; Bruce I988: 23-25; Lund 2000: 2; Migot-Adholla and Bruce I994: 3-4; Toulmin and Quan 2000a: 28; Platteau I996; Quan 2000: $45,49)$. Studies of the governing of common pool resources have provided insights into the circumstances in which local communities can or cannot successfully regulate the management of their natural resources without external interference (Ostrom I990). Other studies emphasize the pervasive negotiability, ambiguity and indeterminacy of customary land law, and the room for manoeuvre this provides for small farmers (Berry I993; Berry I997; Berry 200I; Moore I973; Moore I998). Recently, however, it is increasingly emphasized that "ambiguity may be a cloak for privilege and class as much as a space for action by the powerless," as Peters (2002: 56) puts it. She also observes a reopening of the debate about 'insecurity' of customary land tenure, "not only because it concerns the appropriate conditions for agricultural investment, but because of new worries about increasing inequity in face of land shortage and competition" (Peters 2002: 48). Other authors have also emphasized issues of unequal power relations within communities and questioned the often glorified egalitarian qualities of customary tenure systems. They point out that local institutions are vulnerable to the power plays of elites, as well as to politics of exclusion (Amanor 200I: II-20; Carney and Watts I990; Cousins 2002: 77; Lavigne Delville I999; Moore I998: 42; Oomen 2002; Rose I992: 9I; Toulmin, Lavigne Delville, and Traoré 2002b: I5). And that assertions of a democratic principle of traditional land administration serve the interests of the local ruling class as a means of ideologically justifying their demand for the state to leave local land administration to traditional rulers. ${ }^{\text {I6 }}$

The present chapter stresses the importance that policy is also based on customary tenure research that takes into account the social embedding of land governance, and critically analyses relations of power and aspects of equity within the local community. Struggles for land are never merely a question of land, but a question of property, and of social and political relationships in a broad sense (Lund 2002: I2). Property is not about things, but about relationships between and among persons with regard to things (Bohannan I963; Goody I962: chapter XIV; Moore I998: 33; Von Benda-Beckmann and Von Benda-Beckmann I999: 2I). Property can be seen as sets of rules governing people's rights to access, use and control resources. These rules are not fixed and frozen in time but rather seen as 'rules in use', constantly made 
and remade through social action (Bassett I993: 20-2I; Berry I993; Berry 1997; Berry 200I; Bourdieu I990; Lund 2002; Moore I973; Moore 1998; Shipton and Goheen 1992). It is only within the social, political and historical-geographic contexts that one can understand the forms and outcomes of land conflicts. A processual and institution-focused approach to land issues is therefore needed, with the notions of flexibility and diversity as a starting point.

In the following paragraphs, this chapter analyzes customary land management in peri-urban Kumasi: the negotiations about land, property and authority between chiefs and people; the way these actors try to use, create and negotiate notions of customary law; and the local power structure within which these negotiations are carried out. These local negotiations, however, cannot be disentangled from the discourse and struggles over property, power and meaning taking place at various levels of chieftaincy and government. Supra-local arenas influence local processes of negotiation and adjudication, and the starting position and scope for manoeuvre in these negotiations. An analysis of the mutually constitutive relationship between government and chiefs and its effect on the local arena, will thus be an essential component of any study on the functioning of a customary tenure system. By linking the local to the national, this chapter hopes to also contribute to narrowing the gap between socio-legal field research and policy debates.

\section{Customary tenure in Ghana and Ashanti}

In Ghana, the customary sector holds a large proportion of the land (Larbi, Odoi-Yemo, and Darko 1998). ${ }^{17}$ In the Ashanti Region this 'stool land' is managed by chiefs on the basis of customary law. ${ }^{\mathrm{I} 8}$ The Constitution recognizes the traditional authorities as custodians of the land, and customary law as the regulating order. ${ }^{\mathrm{I}}{ }^{9}$ It furthermore guarantees the institution of chieftaincy and denies parliament power to enact any law which "confers on any person or authority the right to accord or withdraw recognition to or from a chief for any purpose whatsoever." 20

With this constitutional recognition of customary tenure and of the independence of chiefs and their central position in local land management, Ghana is - although not unique ${ }^{2 \mathrm{I}}$ - quite exceptional in Africa. Contempt of customary land tenure remains common in many countries (Toulmin and Quan 2000a: I0, 34, I26, I35-I49, 2II). Some countries, such as Uganda, Ivory Coast and Tanzania, have started to recognize customary law recently. However, often governments regard the registration of customary land rights as a first step of a process that should ultimately lead to the establishment of private title (Okoth- 
Ogendo 2000: I26; Toulmin and Quan 2000b: 2II). ${ }^{22}$ Despite the observed "folklorization of African chieftaincy" (Van Rouveroy van Nieuwaal I987), chiefs in postcolonial Ghana have "been able to secure most of their social, cultural and, most crucially, economic power bases" (Von Trotha I996: 89). This exceptional position with regard to traditional authorities and customary law makes Ghana an appropriate country to study customary tenure. Within Ghana, especially in the Ashanti Region - with its strong chiefly hierarchy, and the Asantehene as the king of all Asantes at the top - chiefs are still very powerful.

Formal representations of Ashanti customary law in case law, textbooks and articles in the Constitution of Ghana hold that the ultimate title, also called the allodial title, of every piece of land is held in common by the members ${ }^{23}$ of a community, and that the chief is the custodian of such land (Danquah I928: I97-200; Ollennu I962: 5-6; Ollennu I967: 252; Sarbah I968: 64-66; Woodman I996: 66). ${ }^{24}$ Chiefs are customarily and constitutionally obliged to administer and develop the land in the interests of the whole community. ${ }^{25}$ Stool lands, therefore, are communal property. ${ }^{26}$

As long as there is vacant land, each member of a community has the right to farm and build on part of it, which gives the member a usufructuary title, also called customary freehold, to the land. ${ }^{27}$ The usufructuary interest can be inherited, and is extinguished only through abandonment, forfeiture ${ }^{28}$ or with the consent and concurrence of the interest holder. The usufructuary cannot be deprived of any of the rights constituting the interest, and not even the chief can make an adverse claim (Asante I969: I05-Io6; Benneh I971; Danquah I928: 206, 221; Ollennu I962: I0, 29, 55-56; Ollennu i967: 254-5; Pogucki I962: I80; Sarbah I968: 67; Woodman I996: I07).

As said, this is a description of the formal written representation of Ashanti customary law. The task of judges, legislators and researchers to adequately analyze and describe customary rules is, however, a difficult one (Mensa-Bonsu 2002-4; Von Benda-Beckmann I985b; Woodman I969; Woodman I977). Customary law is not an unchanging, antiquarian and immutable normative system. On the contrary, it is to a certain extent negotiable and intimately tied to fluctuating social and political relationships and it is constantly recreated and disputed (Berry 200I; Comaroff and Roberts I98I; Gulliver I979: I90-I94; Mann and Roberts I991; Oomen 2002; Otto I998; Ranger I983; Roberts I979: I82; Shipton and Goheen I992: 308; Snyder I98Ib; Starr and Collier I989; Von Benda-Beckmann I979). And colonial and national governments have played important roles in the constitution, definition and perpetuation of customary law (Atwood I990: 661; Glazier I985: 156; Moore I986; Ranger I983; Shipton and Goheen I992: 308). There is therefore often a gap between local and formal representations of cus- 
tomary law (Woodman I969). Furthermore, various versions of customary law can be found within one locality, both in normative statements and in practice (Chanock I989). In the following paragraph, this chapter will describe the varying versions and representations of customary land law currently found 'on the ground' in periurban Kumasi. ${ }^{29}$

\section{Struggles for land in peri-urban Kumasi}

\section{Chiefs' Legitimizing Discourses}

The large-scale leasing out of communal farmland by peri-urban chiefs is diametrically opposed to Ashanti customary convention as sketched above. This poses the question of how these chiefs try to legitimize their actions. Within peri-urban Kumasi two different legitimizing discourses are found.

Most chiefs claim that the customary rules of Ashanti land tenure sketched above date from the days when communities were involved in subsistence farming in land-abundant areas, when not land but people were of value to the chief and the community. Now that market production, population growth, and urbanization have enhanced the economic value of land, these rules are outdated and need to be adjusted to modern circumstances. They argue that the conversion of farmland into residential land cannot be avoided ${ }^{30}$ and that communal land that can be used in a more productive way should be brought under chiefly administration. ${ }^{3 \mathrm{I}}$ They therefore proclaim that "it is a law that when the town is growing and it comes to your farm, you do not have any land." 32 According to this view, when the village expands and reaches someone's farmland, this land falls back into chiefly administration, giving chiefs the right to allocate it to outsiders for more lucrative residential purposes. These claims have seriously weakened the value and security of the usufructuary interest: when there is a demand to change the use of land from agricultural to residential, individual farmers lose the security of their usufructuary rights and the chief claims the power to reallocate these lands.

Some chiefs, however, are taking the argument much further and are venturing to manipulate and shift the meaning of communal land ownership. They claim that their rights to administer stool land do not derive from their function as caretakers on behalf of the community, but instead assert that "land belongs to the royal family, since it was members of the royal family who fought for the land" and the chief has administrative powers over stool land as the leader of the royal family. ${ }^{33}$ Such manipulation is facilitated by the varying ways in which certain words, such as stool, stool land and ownership, are used in dif- 
ferent contexts. For instance, the term stool is alternately used to denote the whole indigenous community, the royal family, and the office of the chief. According to these chiefs, the royal family had only given the land out for farming purposes, to temporary caretakers, and can reclaim it when its use is changed without any need for compensation. "The farmer does not lose any land since he did not own any land. The farmer is only the caretaker for the chief. The land was given to him free of charge, so how can he claim part of the money when it has been sold?"34 This reasoning degrades the nature of the customary rights of usufruct. The freehold is transformed into a permissive right of tenant-like character, based on the leniency of the chief instead of on the communal ownership of the land. Obviously, this severely reduces the security of these usufructuary rights. The allodial title proportionally gains in weight and shifts from the community as a whole to the royal family, on whose behalf the chief claims outright ownership. ${ }^{35}$ Here again, the ambiguity of certain words facilitates manipulation. The fact that the allodial title holder is often defined as the owner, without also referring to the usufructuary title holder as the owner of certain rights, gives ample leeway for reinterpretation.

The argument of the first group of chiefs - that communal land which can be used in a more productive way should be brought back into chiefly administration - is only convincing if the proceeds of the conversion are used for community development such as infrastructure, education and alternative livelihood projects, which might help inhabitants of the village to make a living after the loss of their agricultural land. ${ }^{36}$ Although all the chiefs interviewed - even the ones who claim that land ownership lies with the royal family and not with the whole community - acknowledged that they have at least a moral obligation to use part of stool land revenue to compensate the farmer and/ or for community development, actual practice differs considerably.

The neighboring villages of Jachie and Tikrom offer two extreme examples. In Jachie, the chief demarcated a large part of the village farmland for residential plots and allowed members of the community to buy this land at a very low price. The remaining plots were leased to outsiders for residential purposes. All the revenue generated has been used for community development. In the four years of his reign, the Jachiehene has built a library, a school, and a palace, and has allocated part of his land to a technical school in exchange for scholarships. The neighboring Tikromhene provides the opposite example. He has converted and leased most of the farmland in his village without giving the community members any part of the demarcated land or any financial compensation. When a member wants a residential plot, he has to pay the market price. Out of the revenue from stool land leases, almost nothing has left the chief's palace. ${ }^{37}$ As the above-mentioned examples 
of Tikrom and Jachie illustrate, practices regarding the division of land and revenue differ enormously. On average, however, chiefs receive unsatisfactory marks from most villagers for their administration of the land. ${ }^{38}$ "So much money goes to the chief, and so little to development"39 and "Due to the greedy nature of landowners (i.e., chiefs) there is not much development in this town" 40 are utterances heard regularly in the villages.

\section{Local Negotiations, Struggles, and Debates}

The chiefs are not the only actors in stool land administration. Local land administration practices result from continuing processes of negotiation and are not only shaped by the ideology, claims, and actions of the chief but also by the extent to which these are accepted or contested locally and nationally. The chiefs' actions in peri-urban Kumasi and their severe effects on the livelihoods of the people are causing a great deal of turmoil among community members. Individuals, families and other groups of people are challenging the chiefs' actions. ${ }^{4^{\mathrm{I}}}$ In some villages, people have tried to resist the reallocation of land by the chief per se, while in other villages the reallocation itself has been accepted but the way it was done was contested, especially the division of revenue accrued after the conversion.

\section{i. Resistance against the chiefs' reallocation of land}

Outsiders started to look for residential land in the village of Brofoyeduru about fifteen years ago. "At first it was the chief selling these plots, but the farmer did not get his right percentage," i.e., the chief paid no compensation to the farmer. ${ }^{42}$ After a while, the chief's sisters went to talk to him and he allowed first one and then all of his siblings to sell their own land. When word got out, other people also started selling. "The chief is letting it go. He signs the papers after the sale for some money." 43 Although the people in Brofoyeduru thus successfully resisted the actual sale of their land by the chief, they do not in general deny the chief's right to sell. Some villagers explained their behavior as follows: "The right thing would be for the chief to sell it. But if the chief does that, the farmer does not get much money. Since everyone is poor here, the chief has to allow it."44

In Besease, unlike in Brofoyeduru, many people deny outright their chief's claim that he can reallocate their land. The majority of the villagers acknowledged the chief's right to be informed about a sale, to sign the land allocation papers, and to receive a signing fee for this service - although some said it should be the buyer who takes care of these issues and not the seller - but they claimed the farmers were the only ones to initiate a sale and to receive the money paid for the land: 
"When the town reaches my land, I can sell it. The abusua panin (head of the extended family) and the chief have no say in that" 45 ; "If the chief wants a third of the money when I sell land, I will take the case to court." ${ }^{6}$ Land transactions in Besease thus display ongoing struggles between the four land-owning chiefs and their people. "If you are very persistent, the chief cannot take your land away," a farmer explains. "You can sell it and give part (of the money) to the chief. But if you are unlucky, the chief will take the land, and if you don't fight it, you won't get anything." 47

Struggles over land can sometimes lead to violent incidents between villagers and the chief. For instance, the Beseasehene sold land that did not belong to his family. When the buyer started to develop the land, the family that owned the land stopped him. After the buyer applied to the chief to recover his losses, the chief "went to the land-owing family to plead, but he nearly got beaten up." ${ }^{8}$ In some villages there have even been large-scale violent uprisings of commoners against the chief. For instance in Pekyi No. 2, where the chief sold a large part of the village land to the Deeper Life Christian Ministry and then pocketed the money, the commoners chased both the chief and the church representatives out of the village, killing one of the latter in the process.

Of the nine villages studied in-depth, only in Boankra - where there has not been a chief for the last fourteen years - did the royal family seem to acknowledge the families' rights to initiate the sale of land: "When the new chief comes, the families can still sell their own land, but with the consent of the chief, who will 'take something' for the stool."49 However, it remains to be seen what position the royal family will take in land negotiations when a new chief is enstooled. ${ }^{\circ}$

\section{ii. Resistance against the way chiefs reallocate land}

In a number of the case-study villages, people did generally accept the fact that chiefs were reallocating community land but they vehemently opposed the procedure and the division of revenues. The previously mentioned village of Tikrom presents a worst-case scenario with regard to community development. According to a Unit Committee member ${ }^{5 \mathrm{I}}$, "the Tikromhene is selling land without consulting anyone, compensating the farmer, or giving part of the revenue to the town," and part of the remaining land has been degraded or even destroyed as a result of sandmining. ${ }^{2}$ Furthermore, the chief does not abide by the planning scheme and has, for instance, sold land that was reserved for the school.

A long process of consultation took place between the chief and the community. At a range of village meetings the people requested a substantial percentage of land revenues for community development, but 
to no avail. They then tried to involve the chief from their place of origin, but this chief did not want to come and talk to his 'son.' As the Tikromhene comes directly under the Asantehene, the former assemblyman $^{53}$ then wrote a petition to the Asantehene in May 2002. However, the case has never been called before the Asantehene and it is assumed by some that the Tikromhene has encouraged the secretary of the Asantehene to remove the petition from the files. In addition, the former assemblyman has brought in the Environmental Protection Agency (EPA) to investigate the chief's sandmining close to streams. The EPA came, looked, and reproached the chief, but does not have the power to prosecute. Such power lies with the District Assembly but it is rarely used. A local radio station discussed the sandmining problem in Tikrom in one of its programmes, in which the assemblyman appealed to the Asantehene for help, but there has been no response.

As the example of Tikrom shows, local assembly members and Unit Committee members often play an important role in challenging misadministration by chiefs. One of their popular procedural solutions to the misadministration of stool land is the establishment of a village committee, usually called a Plot or Land Allocation Committee, to oversee the proper allocation of village land. Such a committee usually consists of representatives of the chief and his elders, and representatives of the village, often Unit Committee members. The Plot Allocation Committee checks that the site plan is in accordance with the planning scheme and it has to sign the allocation papers. The existence of such a committee usually coincides with the transfer of a fixed portion of the revenue to the community for development. Although many chiefs pay lip service to such committees, they usually work with a committee made up solely of elders and the chief himself, and popular attempts to set up committees with a broader representation have often been frustrated by the chiefs (cf. Edusah and Simon 200I).

The kinds of activities undertaken in Tikrom to challenge the chief's style of stool land administration were also found in many other villages and appear to be a common response to misadministration by chiefs. Their success is often limited, leaving the people with feelings of desperation or resignation that they have been left to their own devices. The following statements by two former assembly men aptly illustrate these feelings: "In Europe, if a government is criticized three times, the government goes. But here people come to beat you up instead"54 ;"People who lose their land to the chief usually don't go to a chief or to court, normally they give up." 55

Because of this lack of success in negotiations with the chief, many people do not aim their anger and resistance at the chief who is selling the land but at the buyer. Both my fieldwork and a study of pending cases at the High Court of Kumasi show that the farmer, who is angry 
that his land has been sold by the chief, often tries to restrain the buyer from going onto the land and building there. For instance in Adadeentem, the former chief sold substantial parts of the community's land. This aroused a lot of dissatisfaction amongst the people but no concrete actions were taken against the chief. One of the villagers, however, sued the buyer of a vast tract of land in the High Court of Kumasi. Another example of the 'buyer loses out' principle is found in Besease, where the Beseasehene sold two plots of the land belonging to his subchief, the Kontihene. On finding out about the sale, the Kontihene first "caused trouble with the Beseasehene," but "we enstooled him, so (...) we don't want to quarrel with him. But the buyer can't come and work on it. If you come to work you will meet the Konti." 56

\section{Power Configurations in the Villages}

Practices of local land administration result from continuing struggles and negotiations about land, property, and authority between the chief and community members. A valid question to ask is why resistance is more successful in some villages than in others. ${ }^{57}$ Obviously this has a lot to do with the personalities of the chief and his opponents. But another part of the answer lies in the power configuration of the local arena in which these struggles are taking place. For instance, does the village have one, two, or more chiefs, or no chief at all? And if a village has several chiefs, do these chiefs collaborate or compete with each other? Other determining factors are whether there is strife or unity within the royal family, whether the chief or his opponents have a good relationship with the paramount chief or the Asantehene, and whether powerful people, for instance members of parliament, come from the village. A chief's position within and outside the community and his ability to build coalitions with his elders, his family, and other powerful people within the community are crucial for creating room for manoeuvre with regard to land administration. Although the scope of this contribution does not permit in-depth discussion of all these variables, two examples are presented here as an illustration.

Besease has four land-owning chiefs and it is generally well known which land falls under which chief. Nevertheless, villagers who wanted to sell their farmland without involving their chief have occasionally approached one of the other chiefs with a request to sign their land allocation paper. For instance, the Aduana family in Besease had been given land by the Kontihene, the head of the Agona family. But when the Aduana wanted to sell their land, they asked a different chief, the Beseasehene, to sign their allocation papers. Although the Beseasehene had no right to do so, breaking the rules earned him a signing fee. The Aduana also gained from this scheme since the Beseasehene, as a 
'stand-in chief', was in no position to demand a substantial part of the revenue, and settled for a lower signing fee. On discovering the scam, the Kontihene challenged the sales: "I wanted to take the Aduana to court, but they are half-brothers and half-sisters so I couldn't do that. The Aduana apologized and are not selling anymore but all the plots have been sold and the money squandered." 58

The presence of several chiefs in one village offers opportunities to play one off against another other but such a multi-chief configuration can at the same time enlarge the challenge of getting the chiefs to administer land in the interests of the community. If several chiefs mismanage stool land, the conduct of one will be partly legitimized by the similar conduct of another; amidst uncertainty about people's rights, the concerted behavior of chiefs can stake a claim to legitimacy.

A number of the earlier-mentioned characteristics are evident in Boankra. This village has been without a chief or a regent for fourteen years following a dispute between rival factions of the royal family. One of these is supported by the paramount chief of the area, who enstooled the chief candidate of that faction as Boankrahene during a ceremony at the palace. This enstoolment was challenged by the queenmother and Boankra elders at the Regional House of Chiefs in Kumasi. The House of Chiefs decided in favor of the queenmother, stating that she should be the one to choose a new chief. By February 2004, a new chief had still not been installed but the paramount chief has continued to countersign land allocation papers signed by his preferred chief candidate - on condition of the payment of a substantial signing fee. This signature supposedly gives the sales a semblance of legitimacy and makes it possible for the buyers to acquire a building permit at the District Assembly.

\section{Traditional Controls on Chiefly Administration}

Chiefs often reject people's suggestions and claims about adjusting stool land administration and continue to rule as they have done. This poses the question of how it is possible that these chiefs cannot be steered clear from their devastating track. Are there no checks and balances on their administration? A literature survey of some of Ghana's 'grand old men' in the field of customary land tenure yields the following quotes: "(T)he occupant of the stool can only bind the stool, i.e., the town or community, if he acts with the consent and concurrence of the whole town or community represented by the subchiefs, and the principal councilors from the various sections" (Ollennu I962: I30). "Hereditary59 councilors, or elders as they are called in the lower councils, and chiefs or subchiefs in the higher ones, are the heads of houses, families, or towns who have been elected by members of a 
house, family, or town to be their respective head, patriarch, or chief. (...) They hold their offices in the pleasure not of the Chief or head Chief, but by the sufferance of the people who have elected them to the Council. (...) It is of utmost importance, in view of our form of government, for the Chief, who is always the President of his Council, to give due weight and make full allowance of the expressed opinion of these councilors" (Danquah I928: 57). "The chief was bound by his oath to consult the elders on all matters, and to obey their advice" (Busia I95I: I4). To supplement these authoritative, but not too recent, writers $^{60}$ with an influential, contemporary voice, I turn to Kasanga who, less specific but equally romantic, states that "there are reasonable checks at the local level on almost everybody" (Kasanga 2000a: 72; cf. Kasanga and Kotey 2001: 3I).

According to these writers traditional responsibility for village chiefs thus rests on two pillars. The first pillar is made up of a council of elders, selected by and representing all major factions of the community, without whose consent the chief cannot make any decision. The second pillar consists of the possibility of destooling seriously malfunctioning chiefs. Leaving aside whether traditional rule was ever so equitable and well-balanced as these authors claim - which has been convincingly refuted in the extensive oeuvre of McCaskie (including McCaskie I995; McCaskie I992; McCaskie 2000a) - current performance of chiefs in peri-urban Kumasi at least disabuses us of the idea that the two pillars function effectively in present-day village practice.

To begin with, in a number of case study villages, the council elders are primarily or even entirely selected from only the royal family and not from the important families in the community, as in Kotwi. The Kotwi stool was originally carved out of the Asampong stool, and the Kotwihene was like a subchief to the Asamponghene and thus did not have his own subchiefs. Later the Kotwihene was upgraded and he now swears his oath directly to the Asantehene. Although he could now have subchiefs, he has not installed any. He has continued to discuss village affairs with the elders from his family, and when there is a public ceremony the Asamponghene and his subchiefs will join the Kotwihene and his elders. The absence of a council representing the whole community was encountered in a number of the other case study villages as well. Furthermore, the rule that elders hold their offices not in the pleasure of the chief but to serve the family that has elected them also seems to be under strain. For instance in Nkoransa, where the secretary of the chief explained that "it is not the rule that a certain family always brings a subchief. It is the chief who picks them. When one dies, he can choose a new one." ${ }^{\prime \prime}$ This is underpinned by the abundance of conflicts between elders and their own family, who can no longer dismiss them when unsatisfied. ${ }^{62}$ Regardless of the 
composition of the council, the chief often co-opts his elders by sharing the benefits from land administration with them, removing their incentives to effectively check the use of power and, if necessary, to stand up against the chief (cf. Abudulai 2002: 83). According to a UC-member of Tikrom, "the subchiefs support the chief because they get a share of the money. If they argue with him, they won't get anything." ${ }_{3}$ Even at the Asantehene's Land Secretariat it is acknowledged that "in many villages the elders connive with the chief." ${ }_{4}$ And those elders that are not co-opted are often simply ignored by the chief, as is aptly illustrated by the following statement: "Beseasehene is a new chief. He doesn't mind the rules," says his Kontihene subchief, "I tried to talk to him, but he didn't take my advice. If I wasn't educated, he would try to cheat me as well."65

When the people of a community want to destool their chief, a case has to be brought before the Traditional Council, which is made up of the paramount chief and his subchiefs. ${ }^{66}$ A first hurdle is that destoolment charges cannot be brought by commoners but only by the 'kingmakers', i.e. those subchiefs and members of the royal family who can also make or enstool a chief (Hayford I970: 36). As discussed above, these subchiefs are often co-opted and are therefore not likely to take the lead in actions against the chief. And if they do dare to do so, according to one of the subchiefs of the Ejisuhene, this is only "after many years of wrongdoing, the chief will first be given the benefit of the doubt"; to explain why they have waited so long to start a destoolment case against the chief, he adds: "The kingmakers have deposed the previous Ejisuhene and installed this one, of whom they had high expectations. They now lose part of their legitimacy when they want to destool the one they selected." 67 If those years of waiting are added to the years the destoolment procedure itself may take, it can be seen how a chief can easily come to sell a considerable amount of stool land and spend the proceeds as well. A second obstacle lies in the fact that the paramount chief, who chairs the Traditional Council, often has a direct interest in who occupies the village stool, mainly because of his claims to a share in the villages' land revenues. The paramount chief of Ejisu for instance favored those chiefs who sold large amounts of stool land and shared the proceeds with him. The fact that this did not usually leave much land or revenue for the community did not seem to bother him. Furthermore, to mention a third hindrance, the members of the Traditional Council consist of direct colleagues of the chief-ontrial. Many of the current destoolment charges are to do with land administration in one way or another. And often the charges against the chief-on-trial, such as selling farmland and not using enough stool land revenue for community development, are also points of discussion 
in the villages of the judging chiefs. Clearly, their personal interests in such cases may stand in the way of objective and impartial judgment.

The main customary checks and balances on chiefs - ruling in council with subchiefs and the possibility of destoolment - are not therefore very effective. One can add to this the fact that chiefly accountability is extremely low. Most land administration is concealed due to a lack of registration. A good chief may account for his administration of his own accord but this is an exception rather than the rule. Some elders and chiefs claim that "nobody has the right to ask the chief to account," 68 and "if it goes wrong, there is nothing to do about it." 69 They explain this by the fact that the chief also has his professional income and it is impossible to know whether he is spending personal or stool money. Or they say that "the chief does not receive any remuneration but does have job-related expenses, to which the people do not want to contribute" 70 and that the chief continues to have obligations for which customary provisions have ceased. ${ }^{7 \mathrm{I}}$ Others claim that to ask a chief to account for his expenditures is considered a vote of no confidence. "If a chief does his work well, no one will bring him to account." 72 Most people will not dare to do this unless there are clear indications of serious misconduct by the chief. And even then, "who is to bell the cat"? The chief is still a powerful figure in most villages and one is certain to encounter his wrath by highlighting irregularities in his actions. Moreover, taking action against a chief violates his traditional sanctity. Most people would consider it the task of the royal family and if the royal family does not enact this task, how can commoners be expected to take it upon themselves? The only kind of functioning accountability is what I call 'end-term-accountability.' During destoolment procedures, a chief has to account for all stool revenue, but by then most of the money has usually been spent and is very hard to recover. Besides, as noted, starting a destoolment procedure brings its own difficulties.

In sum, the current customary system lacks effective checks and balances and accountability, but in fact this is not surprising when the historical development of the position of the chiefs is taken into account. During the colonial period, local checks and balances and accountability structures were severely distorted when the British government overrode the traditional rules of investiture and reserved for itself the right to appoint and dismiss chiefs (Annor 1985: I53; Busia I951: I05-6; Toulmin and Quan 2000a: I0; Van Rouveroy van Nieuwaal I987: II). With this 'devolution', as Von Trotha (I996: 8I) calls it, the local attachment of the chief to some extent gave way to his responsibilities and loyalties towards the government. Where commoners tried to reassert local checks and balances, a chief who was on friendly terms with the British administrator was easily able to discredit the commoners by 
branding them as malcontents and troublemakers (Kumado I990I992: 203; McCaskie 200ob).

The abolition of the position of Nkwankwahene, the elected representative 'chief' of the commoners, by the Ashanti Confederacy Council - supported by the British - in the I940s also had a profound effect on local checks and balances and accountability structures. Since the subchiefs and elders were restrained in their criticism of the traditional administration due to their proximity to the chief, the Nkwankwahene served to infuse the views of the masses in the traditional government, for instance in enstoolment and destoolment procedures, and as a channel for common discontent (Busia I95I: IO, 2I5-6; Wilks I998: I59). By abolishing this channel, the chiefs and the British government hoped to put an end to the frequent actions by commoners against chiefs who were abusing their position. They thus aimed to curb the youth and stabilize traditional communities by removing the channel of discontent, rather than by addressing its causes.

The British gave the chiefs strong rights in land, by accepting their claims that according to customary law all land belonged to a customary community with the chief as the administrator. However, they did not give the chiefs free reign in all aspects. They regularly held them to account, monitored the by-laws they made, and intervened in local conflicts, thereby to some extent compensating for the lack of local checks and balances, at least in the field of land administration (Crook I986: 88; Dennis I957). Post-colonial governments in Ghana have shown an ambivalent attitude to chieftaincy (Kofi-Sackey I983; Kumado I990-I992; Nugent I994; Ray I996; Van Rouveroy van Nieuwaal I987, I996) and the pendulum has swung between devolution and the prohibition of governmental interference. Although under the current Constitution the Ghanaian state is not permitted to exercise its sovereignty over chiefs regarding their enstoolment and destoolment, ${ }^{73}$ the pre-colonial local checks and balances and accountability structures have not been rebuilt. A crucial question therefore is whether the current government can also impose state constraints on the administration of chiefs to compensate for the lack of local checks and balances.

It is worth considering whether any regulation or change towards more equity and community influence can be expected to come from within the traditional system. Some chiefs distribute land and land revenue fairly among community members and display a serious commitment to developing their villages. Could these chiefs serve as role models, and can they be expected to advise or influence their fellow chiefs? We have seen that at all levels of traditional leadership - from the village level to the Asantehene - discourse and practice move away from individual rights of community members in stool land to the unrestricted rights of the chief to administer this land. There is no one-to-one 
relationship between development-oriented leadership and the willingness to abide by certain principles of good governance, such as accounting for administration and cooperating with a representative Plot Allocation Committee. For instance, the earlier-mentioned Jachiehene, who was enthusiastically developing his village, not only abolished the local Plot Allocation Committee but stated outright that "land in Jachie belongs solely to the royal family" and "a chief does not need to account to anyone, only if things go wrong." 74 Most chiefs, including those who are development oriented, have supported rather extreme levels of chiefly discretionary powers. This has usually made them unwilling to condemn any misadministration by chiefs in other villages, let alone call such chiefs to account. In addition, chiefs are, in general, unwilling to interfere in other chiefs' business, with an appeal to the sacrosanct 'internal village affairs.' They form a united front when it comes to asserting their rights and are reluctant to check the boundaries of chiefly power. It is doubtful whether much can be expected of them with regard to curbing any mismanagement of stool land.

Within the Ashanti Region, the Asantehene forms the apex of the traditional hierarchy. Undoubtedly an impartial authority at the top of the traditional system could check many abuses. The current Asantehene, installed in I999, seems to be concerned with the development of the area and the role chiefs can and should play in this respect. ${ }^{75} \mathrm{He}$ is actively trying to settle the numerous chieftaincy and land disputes. ${ }^{76}$ In various dispute settlements the Asantehene has proclaimed that land and land revenue should be divided between the chief, the elders, the stool (for expenses), the farmer (for compensation) and the community (for town development). ${ }^{77}$ But the need to keep his chiefs satisfied restricts his room for manoeuvre on the sensitive issue of land administration. Furthermore, the integrity of his land secretariat is being challenged and his own rights to land are not going undisputed..$^{78}$ The Asantehene's readiness and capability to influence local land management are, therefore, uncertain.

\section{State involvement}

We have seen that the 1992 Constitution vests all customary or stool lands - which constitute approximately 80 per cent of the land in Ghana - in the appropriate stool on behalf of and in trust for their people, and confirms that such lands be managed by traditional authorities. ${ }^{79}$ Notwithstanding these provisions, the state has sought to regulate certain aspects of stool land management. Over the years various governments have taken piecemeal measures in the areas of land use planning, land title registration, issuance of formally registered leases, stool 
land revenue collection, and adjudication of land disputes. This chapter will first describe both the mandate and the actual functioning of one of the state institutions involved in this field, the District Assembly, as an example to show the checks and balances it is able to place on chiefly administration. Then it will emphasize some of the political constraints state institutions face by looking at state discourse with regard to chieftaincy in general, and land administration in particular.

\section{District Assembly}

The Local Government Act, I993 (Act 462) designates District Assemblies (DA), which have been created since I986, as the main planning authority charged with the overall development of the district. With regard to land administration, they have legislative powers to make bylaws with respect to building, sanitation, and the environment. The preparation and approval of planning schemes, the granting of building permits, and the enforcement of regulations and sanctions for noncompliance all rest with the DA (Kasanga and Kotey 200I: 9). Villages and towns are supposed to draw up a land use planning scheme, with help from the Town and Country Planning Department (TCPD) of the DA. Such a planning scheme designates the uses of the various areas, and shows the boundaries of the individual plots. When a prospective developer applies for a building permit, the TCPD checks whether the site plan conforms with the planning scheme, and whether the allocation paper is signed by the local chief.

Ammissah et al. argue that "Since the main aim of the chiefs is to maximize financial returns within the shortest possible time, important land uses such as open spaces, playgrounds, schools, markets, refuse dumps, roads, etc. are sacrificed, in order to augment the supply of building plots. This is a major cause of haphazard and unauthorized development in all statutory planning areas." $8 \circ$ By means of the land use planning process, the DA could provide some checks on the land administration by chiefs, preventing double allocations, ${ }^{8 \mathrm{I}}$ and reserving land for public purposes or even for agriculture. Chiefs can, however, prevent the drawing up of a planning scheme, for "if a chief does not cooperate, you cannot make a planning scheme," explains the director of the TCPD in Ejisu. ${ }^{82}$ "It is in the benefit of the chief not to have an approved planning scheme," he continues, "therefore the co-operation of chiefs is not very high. Most have their own unapproved planning scheme." 83 Furthermore, although knowledge of planning schemes and building permits is increasing, most people still do not comply with the demand for a building permit, or the building precedes the formal planning process, due to the lengthy ${ }^{84}$ bureaucratic procedures and the costs involved in obtaining a building permit (Edusah and Si- 
mon 200I: section 4.4; Hueber and de Veer 200I: I9I; Toulmin and Longbottom 200I: 29-30). ${ }^{85}$ Finally, fieldwork showed that the implementation of planning regulation is often lacking, due to a lack of personnel, funds and logistics (cf. DFID 2004: I2; Hueber and de Veer 200I: I88-I89; Kasanga and Kotey 200I: 9-10) and mismanagement and corruption (cf. Kasanga I996: 99; Kasanga and Kotey 2001: iii). And even when violations are found, severe sanctions such as demolition of unauthorized structures are avoided (cf. Hueber and de Veer 200I: I9I).

Every electoral area has its own representative at the DA. In many villages, these local assembly members and the members of the Unit Committee (UC) are public figures, who are widely known, easily accessible, and often most actively involved in development of the community. They are aware of the fact that a lot of money for town development could come from allocations of stool land. It is therefore not surprising that in those communities where the chief is unwilling to share the wealth from land allocations, it is often the UC-members and the assembly member who are in direct confrontation with him, or who lead the public actions against him. While these local government representatives are thus a local force to be reckoned with, they are often not backed by the district authorities. The District Chief Executive (DCE) of Ejisu, for instance, although he acknowledged and resented the negative effects of chiefly land conversions in his district, did not go any further than to occasionally make a public statement that chiefs should spend part of the land revenues on community development. When we proposed the idea to back up local Plot Allocation Committees (PACs) - which are usually installed and co-managed by members of UCs - by providing building permits only when allocation papers carry the PACs signature, he rejected the proposal because land revenue would then be spent by the UC, and not fall under his responsibility. ${ }^{86}$ It thus seems that when the DA does not have a financial interest, it tries not to get involved in what they call 'internal village affairs.' More generally, during their inauguration ceremony UC-members and assembly members are explicitly told to refrain from interfering in chieftaincy and land matters. ${ }^{87}$

\section{Governmental Discourse}

Due to the above, the DA does not in reality exercise effective control upon chiefly administration of land. That is also the case with most other governmental institutions created with the mandate to act as a check on stool land management. This is not only caused by lack of funds, staff, and material, and by mismanagement and corruption but also by a lack of political support, which manifests itself in governmen- 
tal discourse. In the media, government officials at all levels regularly and vehemently proclaim that they will not 'meddle in chieftaincy affairs." 88 According to Boafo-Arthur president Kufuor himself "has made it clear that the current ruling party is not interested in meddling in chieftaincy affairs" (Boafo-Arthur 2003: 138). These 'non-interference' statements are sometimes made in reaction to chieftaincy disputes, over which the law explicitly declares the government has no jurisdiction, ${ }^{89}$ but also in general, expressing that the government will not interfere in chiefly administration, such as in the field of land management. For instance, an official at the Ministry of Lands and Forestry asked in an interview: "Is it the business of the government to address the accountability of chiefs? Within the local system there exists accountability, they can destool a chief. We do not want to impose accountability on the chiefs, since land is essentially a chief's thing." 90 And the former Minister of Lands and Forestry, prof Kasanga, argued that "The state should not attempt to enforce local checks and balances. This should be done by the citizens themselves."9I Obviously, such governmental statements communicate little fear of stately control and allow chiefs ample room for manoeuvre.

These statements form an element of a wider 'policy of non-interference', which can also be witnessed in certain actions, such as the fact that at the inauguration of DAs and UCs their members are invariably told to abstain from chieftaincy affairs, and by the refusal of the DCE of Ejisu to check allocation papers for a signature of the Plot Allocation Committee, if such a committee exists in the locality. A last salient example can be found in the wording, drafting, and content of the National Land Policy - the first comprehensive land policy ever formulated by the Ghanaian government - and its implementing program, the Land Administration Program..$^{2}$ Although program and policy aim to tackle the current problems in land administration, both the role of chiefs in the administration of stool land - including the tendency of chiefs to adopt landlord-like positions - and the possible checks and balances the state could put in place regarding stool land administration, are not critically examined. On the contrary, the role of chiefs as caretakers of stool land is taken as a fixed point of departure for all changes with regard to customary land administration. One might say that the policy of non-interference is currently so pervasive that some problems and possible solutions are not even open to public discussion.

Chiefs are trying to capitalize on the positive stance of the current government towards them by rekindling discussions on a number of subjects, such as: the creation of a second chamber of parliament made up of chiefs; the representation of chiefs on DAs; the divesting of lands vested in the government, to be placed in the hands of the chiefs; and 
an increase of the percentage of stool land revenue to be disbursed by the Office of the Administrator of Stool Lands to the chiefs. ${ }^{93}$ The fact that chiefly statements on these issues at workshops and policy meetings often go unchallenged gives another indication of the affirmative attitude of the current government towards chiefs and chieftaincy issues.

The policy of non-interference can be explained partly by the political power of the chiefs, who are still regarded as very influential and votebrokers, especially in the rural areas. In addition, the current tendency to fill chieftaincy positions with highly educated professionals blurs the traditional distinction between the state elite and chiefs, and creates new alliances between these two groups (Ray I992: I09-II3). The elite of the party presently in power, the NPP, is especially closely connected to the chiefs. Not only does it have its stronghold in the Ashanti Region, with its powerful chiefs, but president Kufuor himself is through marriage connected to the royal family of the Asantehene. Many members of the current government, up to high levels, are royal family members in their hometown. Furthermore it could be argued that the rampant irregularities and mismanagement by state institutions in procedures of compulsory acquisition of land do not give the state a strong moral position from which to judge the quality of chiefly land administration (Kotey I996). 94 Moreover, when the state wants to acquire land itself, a good relationship with the chiefs involved is useful. Nevertheless, there is an internal debate between modernizers and neo-traditionalists within government, which is quite intense and highly sensitive. The modernizers, particularly in the land agencies and the Land Administration Program Unit, are trying to break the silence surrounding the misadministration by the chiefs, but their efforts are being thwarted by their superiors. Altogether, it seems that there is currently no political party willing to enter into any real battle with the chiefs, of the sort that land reform would cause.

\section{Conclusion}

\section{Customary Law Manipulated?}

This chapter presents a multi-level analysis of customary land management in peri-urban Kumasi and the relations of power and issues of equity involved. It has described how the new value of peri-urban land has triggered a multitude of struggles and negotiations. Although actions, statements, and beliefs as to what is just vary between villages, families, and individuals, one main tug-of-war can be outlined: the struggle between chiefs on the one hand and villagers on the other for the rights to allocate land and share in the revenue. Despite high local 
resistance, the chiefs in a number of case study villages persisted in their style of land management, which was highly lucrative for themselves and sometimes for other selected members of the community such as elders or royal family members - but extremely detrimental to the livelihoods of the poor majority. For indigenous farmers in peri-urban Kumasi customary tenure offers very little security. This raises the question of how chiefs are able to continue acting contrary to the wishes of the majority of the villagers. Although many of the chiefs' current practices in the research area are diametrically opposed to descriptions of customary law in authoritative literature, case law, and articles of the Ghanaian Constitution, the chiefs still claim to act according to customary law, but a different kind of customary law. Not the old version found in literature, legislation, and case law, but a new one adapted to changing peri-urban circumstances. How can the chiefs make such bold claims - that practices diametrically opposed to authoritative descriptions of customary law are in accordance with 'adapted' customary law - and at least in part get away with it? We have come across three explanatory factors.

A first factor was found in the erosion of customary checks and balances on chiefly functioning. Theoretically, these checks and balances are supposed to constrain the chief in his administration of land. But, as we have seen, in many localities the customary notion of ruling in councils with elders or subchiefs has been severely eroded, destoolment procedures are prone to difficulties, and accountability structures are lacking. As a result, commoners are often unable to organize successful resistance. In general, chiefly discourse shows that not much change in the direction of more equity and community influence can be expected to come from within the traditional system in the near future. Limited commitment to principles of good governance and the extreme reluctance of chiefs to interfere in other villages' internal affairs mean that even development-minded chiefs will not engage in attempts to curb the mismanagement of stool land by other chiefs.

The government's attitude towards chieftaincy is the second factor influencing the behavior of the chiefs. The government is currently providing hardly any checks and balances on local land administration. ${ }^{95}$ Its policy of non-interference in chieftaincy affairs - with an emphasis on the sovereignty of the chiefs and on the fact that land administration rests exclusively in their hands - gives additional legitimacy to the chiefs, provides them with ample leeway to administer land the way they please, and places the power to define customary law squarely in their hands. The National Land Policy and the Land Administration Program do not seem to predict any change in this respect in the near future. So while the British colonial government kept chiefly landlord- 
ism in check, the present government is not effectively controlling chiefs' dealings with land.

A third factor to be taken into account is the fact that stool land administration is characterized by a leading position for chiefs and the prominence of customary law. Customary law does not consist of static norms. With the notion of an unchanging customary law as a myth of the colonial era, it has to be recognized that norms and rules themselves are sources of power, manipulated and used selectively by parties in disputes (Chanock 1998; Comaroff and Roberts I98I; Mann and Roberts I99I; Moore I986; Oomen 2002; Otto I998; Ranger I983; Roberts I979: I82; Von Benda-Beckmann 1979). On account of the prominence of customary law in the field of land administration, all actors in land struggles have to legitimize their actions and claims largely with appeals to customary law. ${ }^{96}$ When circumstances change and new opportunities arise, they will try to use the unwritten and somewhat pliable nature of customary law to construct norms in their own interests. Struggles over land will thus often take the form of interpretative struggles over meaning in which "the power to name" can be a highly political issue (Bassett 1993: 2I; Shipton and Goheen I992: 309-3II). The critical question is, which actor or group of actors has the power to issue definitions and is able to mobilize support - from community members, the traditional system and the state - for its version of customary law? Since chiefs are generally regarded as authorities in the field of customary law and as guardians of stool land, they are able to point to custom to acquire and legitimate power over land in the local arena and to resist interference by the state. ${ }^{97}$

This chapter shows that the assumed positive attributes of customary law, such as the embodiment of principles of equity, social security for all, consensus building, and checks and balances to control abuses by chiefs, exist as ideal principles rather than as real life situations in peri-urban Kumasi. Without clinging to a pristine view of traditional rule in preceding periods, it seems safe to state that the democratic and participatory level of traditional rule are currently low. The absence of checks and balances on chiefs in both the traditional and the state system has seriously disrupted the fragile balance between chiefs and people. This has given chiefs the power to abuse their prominent positions as experts of customary law and guardians of stool land and to overstretch the somewhat dynamic nature of customary law by manipulating it to suit their needs and legitimize their claims.

\section{Land Policy}

It is dangerous to generalize about African land tenure systems, since they have been diverse in space and time, dynamic in their response to 
new economic conditions, and often reshaped by colonial and national government laws and policies (Atwood I990: 66I; Cotula, Toulmin, and Hesse 2004: I). Nevertheless, evidence seems to support the claim that the events in peri-urban Kumasi do not stand alone. Many other areas in Africa with a high pressure on land - whether due to population growth, urbanization, immigration, high quality agricultural land, or possibilities for mining or logging - show a severely reduced security of customary tenure, with often a negative role for chiefs, elders and heads of families. In these cases often one or more of the abovementioned explaining factors are found: traditional checks and balances have been more or less eroded; the state gives free rein to chiefs, elders and heads of families; and these traditional authorities can manipulate the negotiability of customary law to serve their own interests (Abudulai 2002; Alden Wily and Hammond 200I; Alden Wily 2003: 20; Amanor 200I: 32-40; Atwood I990: 665; Berry I997: 1235; Brokensha and Glazier I973; Bruce I988; Fisiy I992; Hammond 2005; Goody I979-80; Kasanga et al. I996; Kasanga and Kotey 200I; Lund and Hesseling I999: I43, I49; Maxwell et al. I998; Shipton and Goheen I992: 315; Swindell and Mamman I990). In the face of land competition and the lack of both traditional and state checks and balances, the negotiability and ambiguity of customary law mainly serve certain privileged classes and increase inequity. And this is not a new process either. Similar events have been described since the colonial period (Addo-Fening I990; Fallers I955; Hill I963: chapter V; Rathbone I993). The large amount of literature allows us to conclude that, when the economy rapidly changes and land becomes a high-priced commodity, customary systems are often unable to evolve equitably and the tenure position of local farmers is increasingly precarious.

Despite this crisis in customary land administration, at present the policy pendulum is swinging towards a more positive view of customary tenure systems. This trend seems to a large extent inspired by the practical necessity to start from existing systems and by default reasoning: disappointment with state programs of titling and registration fed by mainly economic research on the negative effects and the lack of positive results of such programs - turned the attention of policy makers towards customary tenure systems. A positive stance towards customary tenure systems should, however, not be born out of weariness with the state. Neither should it be based on idealized notions of customary law - often brought forth by traditional authorities themselves - or stem from research in areas with abundant land only. Not everything customary is by definition good. Concerns of equity and power have to be brought back into the discussion. Without assuming that registration is the solution, this chapter urges policy makers to be more cautious with their optimism about the functioning of customary 
systems, at least in areas with high pressure on land. Policy responses and strategies need to be differentiated, based on analyses whether certain communities do or do not possess the characteristics and institutions to manage their land effectively and equitably. ${ }^{98}$ If the communities are capable of self-regulation, the recognition of local arrangements in land policies will suffice. ${ }^{99}$ If, however, certain groups or actors experience serious negative consequences for their livelihoods, land policy should not - as in the case of Ghana - give free rein to local leaders, but voice its concern with local developments and seriously consider a governmental intervention.

\section{Notes}

I 'Tenure security: Wishful policy thinking or reality? A case from peri-urban Ghana.'

2 'Land, chiefs and custom in peri-urban Ghana: Traditional governance in an environment of legal and institutional pluralism.'

3 Field work in Ghana on which this research is based was supported by the Netherlands Organization for Scientific Research (NWO/WOTRO), the Leiden University Fund (LUF), Mordenate College, and the Adatrechtstichting.

4 In a number of villages, community members can acquire residential land for a lower price than strangers can. Beneficial as this rule should be, as a result chiefs rather allocate the land to a stranger, since more revenues will then accrue. In contrast, in one case-study village this rule of cheaper land to community members has been abolished, because the people, instead of developing the plot, reallocated it to strangers themselves, pocketing the difference in price (interview Jachiehene, 29 June 2003). Cf. Berry 200I: I222.

5 See also Berry 2002a: I24; Edusah and Simon 2001; Hammond 2005; Kasanga and Kotey 200I: I7-I8; Kasanga and Woodman 2004: 204-2I2; Kenton I999: 3I.

6 Kasanga et al. also describe a positive example of peri-urban land management, in the village Gbawe (Kasanga et al. I996: 27-30, 39-40, 59-6I).

7 For more literature on Ghana in general see DFID 200I: I-II, F9-IO; Kotey and Yeboah 2003: 3, I9, 2I, 53; Toulmin and Longbottom 200I: II-III, 30.

8 These nine villages housed a total of twelve land-owning chiefs. My main village of study was Besease, situated approximately twenty-three kilometres from Kumasi on the road to Accra. Furthermore, I have studied four other villages on or near this road - Jachie, Tikrom, Adadeentem, and Boankra - and four villages on the road to Obuasi Ahenema Kokoben, Kotwi, Brofoyeduru, and Nkoransa. All villages were at a range of ten to forty kilometres from Kumasi.

9 Security of land tenure can broadly be defined as the perceived right by the possessor of a land parcel to manage and use the parcel, dispose of its produce and engage in transactions, including temporary or permanent transfers, without hindrance or interference from any person or corporate entity, on a continuous basis (cf. Migot-Adholla and Bruce I994: 3).

Io The distinction made between systems of customary land management and systems of state-led land management does not mean to deny that people may make use of both systems in their dealings with land (cf. Cotula, Toulmin, and Hesse 2004: 2).

II Not all authors regarded customary tenure systems as an impediment. Some argued for the preservation of customary tenure systems, on behalf of their many positive attributes, including access to land and security of tenure for all community members. They 
also claimed that customary tenure systems are flexible enough to respond to changing economic conditions (see for instance Ault and Rutman 1979: I74; Benneh 1967: 27, 32; Gerschenberg I97I).

I2 For China, Hu however claims that the positive impacts of the tenure reform on agricultural growth have been over-addressed and the negative impacts on the agricultural environment have been overlooked (Hu I997).

I3 According to Berry and Quan, however, the new openness to customary land tenure in World Bank policy on land is not always reflected in practice by its operational divisions (Berry 1997: I237, nt. 6; Quan 2000: 36).

I4 Many recent laws protect customary land rights and provide for or allow their registration, such as Uganda's Land Act 1998 and subsequent amendments; Mozambique's Land Act 1997; Tanzania's Land Act and Village Land Act 1999: Niger's Code Rural I993: Namibia's Communal Land Reform Act 2002 etc. It must also be noted, however, that some African countries have maintained or embraced policies abrogating customary systems, as in Eritrea's Land Proclamation 1994 and Burkina Faso's Réorganisation Agraire et Foncière 1984, as amended in I991 and 1996 (Cotula, Toulmin, and Hesse 2004: 5).

I5 In line with numerous people who see the creation of a system of private property rights as the only way to avoid a tragedy of the commons (Ostrom I990: I2), Heller pleas for the elimination of multiple owners through the creation of private property ownership with coherent bundles of rights to avoid the tragedy of the anti-commons.

I6 According to Amanor researchers, governments, international development agencies and donors are inclined to relegate social stratification in local communities to the background, afraid that it may undermine the new paradigm for development (Amanor I999: 10).

I7 Land ownership in Ghana is classified into two categories: private lands and public lands. Around twenty percent of the land area is public land (see article 257 of the 1992 Constitution), which falls into two main categories: land which has been compulsorily acquired for a public purpose or in the public interest under the State Lands Act, 1962 (Act 125) or other relevant statute; and land which has been vested in the president, in trust for the landholding community under the Administration of Lands Act, I962 (Act I23). The rest of the land area in Ghana is private land, which consists, besides a small amount of common law interests, primarily of estates in customary communal ownership (Alden Wily and Hammond 200r: 46-48). According to Kasanga and Kotey the customary sector holds 80 to 90 percent of all undeveloped land in Ghana (Kasanga and Kotey 200I: I3).

I8 The customary community is called 'stool' in reference to the carved wooden stool that is believed to contain the souls of the ancestors and is a traditional symbol of chieftainship. The term 'chief' (ohene) can denote traditional leaders at various hierarchical levels, from heads of one village (odikro) to divisional chiefs (ohene) to paramount chiefs (omanhene) who rule an entire traditional area consisting of dozens of villages, to - in the Ashanti Region - the Asantehene, king of Asanteman. The term Asanteman is used to signify both the geographical entity of all territory under the Asantehene, including the Ashanti Region and parts of the Brong Ahafo Region, and the council of all chiefs of Asante over which the Asantehene presides.

I9 "All stool lands in Ghana shall vest in the appropriate stool on behalf of, and in trust for the subjects of the stool in accordance with customary law and usage (article 267 (I) of the 1992 Constitution)."

20 Article 270 . Article 277 of the 1992 Constitution defines a chief as "a person, who, hailing from the appropriate family and lineage, has been validly nominated, elected or selected and enstooled, enskinned or installed as a chief or queenmother in accordance with the relevant customary law and usage". 
2I For instance in Malawi, all land is initially administered by chiefs (Palmer 2000: 273). Also in South Africa, the chiefs still play a big role in land administration, but attempts are being made to have them functioning alongside an elected local government structure (Oomen 2000; Toulmin 2000: 237).

22 Although this does not count for Tanzania where attempts have been made from I957 to resist the introduction of a private property regime as the basis for social and economic development, contempt for customary tenure is evident in Tanzania from the deliberate refusal of the legislature and the courts to develop customary land law as a body of jurisprudence supporting an important system of land relations (Okoth-Ogendo 2000: I26).

23 The notions 'members of a community' and 'subjects of a chief' are not value-neutral synonyms. To define individuals as members of a community and their chief as the leader, is to depict the community as constituted and governed to a great extent by the voluntary participation of those eligible. Whereas to portray individuals as subjects of a chief, seems to imply limited possibilities of the people to influence the course of administration and to enjoy material benefit therefrom (Woodman I996: 182-I83).

24 Note that the customary 'community' does not include all people living in a geographical unit such as a village, but only the indigenous people.

25 Article 36 (8) of the 1992 Constitution: "The state shall recognise that ownership and possession of land carry a social obligation to serve the larger community and, in particular, the state shall recognise that the managers of public, stool, skin [in the northern regions of Ghana the skin is the equivalent of the stool] and family lands are fiduciaries charged with the obligations to discharge their functions for the benefit respectively of the people of Ghana, of the stool, skin or family concerned, and are accountable as fiduciaries in this regard". See also article 267 (I), I992 Constitution.

26 The fact that the customary land tenure system in Ghana can be called 'communal' does not imply common ownership of all resources and collective production. It rather signifies that a person has to be a member of the group to qualify for an allocation of land for residence and cropping and rights of access to common pool resources. Generally, individual families enjoyed fairly clearly defined spatial and temporal rights of use over different parcels of land. Such family rights were transmitted to succeeding generations in accordance with rules of succession, which usually allowed divisible inheritance (Migot-Adholla and Bruce I994: 5-8). According to Cousins this system should rather be called mixed tenure, comprising individual, family, sub-group and larger group rights and duties in relation to a variety of natural resources (Cousins 2000: I52-I54). The term 'communal' should thus be used with care, also because it conjures up an image of a more egalitarian system than is supported by historical evidence (Atwood I990: 66r; Migot-Adholla and Bruce r994: 4).

27 Some authors claim that the rule that no express grant is needed to farm or build on vacant communal land, has been eroded by the increased use of land, resulting in a need to expressly apportion remaining vacant land. (Ollennu I962: 32; Woodman I996: 9I).

28 Forfeiture results from the denial of the landlord's title.

29 See for a comparison of customary land law in the Ghanaian courts and local customary land practices and an explanation of the gap between these two Ubink 2002-2004.

30 This also seemed to be the point of view in most of the District Assemblies, the highest political authorities at district level (section 3, Local Government Act, I993 (Act 462)). However, with the coming of an inland port in the district, the Ejisu-Juaben District Assembly intended for the first time to preserve some land in the area for agriculture.

3I These assertions are corroborated by the findings of the Kumasi Natural Resources Programme. This study, carried out in 66 villages in peri-urban Kumasi, widely encountered the norm that chiefs consider themselves to have the right to allocate land in which community members have a ususfructuary interest to outsiders for residential 
purposes (discussed in Kotey and Yeboah 2003: 20). This view is also propagated by High Court Accra in Amatei v. Hammond ([I98I] G.L.R. 300). According to Woodman, however, the weight of the authorities seems to support the indefeasibility of the usufruct. Notwithstanding that, he concludes that "( $\mathrm{t})$ he ususfruct may move into decline" (Woodman I98I-2: 202-4).

32 Interview Beseasehene, II May 2003.

33 Interview former Akyeamehene subchief of Tikromhene, 7 January 2004.

34 Interview former Akyeamehene subchief of Tikromhene, 7 January 2004. Since article $267(5)$ of the 1992 Constitution determines that 'no interest in or right over any stool land in Ghana shall be created which vests in any person or body of persons a freehold interest, howsoever described' stool land is officially leased rather than sold. Nearly everyone, however, talks about the 'selling' of land and many people, 'sellers' as well as 'buyers', seem to regard it as a definitive transfer. Notwithstanding evidence from certain parts of Ghana that land has been alienated since the early I9thcentury (Amanor I994; Hill I963: chapter V; Rathbone I996; Wilks I975) the idea that land can be definitely and permanently alienated as in the English concept of an estate in fee simple has been the subject of fierce debates among Ghanaians and their colonial rulers since the I89os (Amanor I999: 45-51). This debate is currently being employed by chiefs seeking to go back on or undo forms of land transfer or rights granted to people in earlier times. This is leading to a highly tense situation in many agricultural areas with high migrant populations (Amanor 2006; Boni 2006; Lentz 2006). In peri-urban areas, however, the question whether the allocations of residential land to outsiders are permanent sales or 99-year leases, makes no difference for the indigenous farmers who, in both cases, lose their agricultural land. In peri-urban Kumasi, this issue was therefore not under discussion.

35 Although the claim that the allodial title to stool land lies with the royal family has been pushed by royal families in Ashanti since the dynastic civil wars of the I88os, the argument that the indigenous farmers therefore have no rights in the land is not supported by history. For instance, when cocoa became a valuable cash crop in Ghana, many chiefs started to levy immigrant cocoa growers with taxes, but refrained from or were unsuccessful in imposing such a tax on indigenous farmers, because these were considered to have an inherent right to farm the land. See for literature on Ghanaian history e.g. Firmin-Sellers I995; Hill I963; McCaskie I995, 2000a, 2000b; Rathbone I996; Wilks I966, I975, I993.

36 According to Danquah's classical treatise of 1928, it is generally assumed that a chief should save a certain part of stool land revenue for the benefit of the community. If it is found that all of the revenue is squandered in undertakings that do not benefit the people, the chief will be questioned, and if the people are not satisfied, deposed (Danquah I928: II7). Although this text dates from I928, it is still regarded as authoritative in Ghana, and often referred to in literature and court decisions. Woodman in his review of Amatei $v$. Hammond (see note 55) also implies that the High Court in this decision had the common best interest in mind and "some measures of equality" (Woodman I98I-2: 204).

37 When confronted with the many development projects in the neighbouring village of Jachie, the Tikromhene pointed out that he was building a primary school in his village. On further enquiry in the village, however, it turned out that this project was being financed by the EU.

38 See chapter 5 .

39 Interview youngster Besease, I5 June 2003.

40 Interview Unit Committee Ahenema Kokoben, II November 2003. 
4I During my fieldwork I did not find any NGO involved in land matters in peri-urban Kumasi. Discussions with church leaders in Besease revealed that they were not in any way involved in land issues.

42 Interview members of the Unit Committee and the royal family of Brofoyeduru, 5 November 2003 .

43 Ibid.

44 Ibid.

45 Interview farmer in Besease, 27 August 2003.

46 Interview farmer in Besease, 29 August 2003.

47 Interview farmer in Besease, 27 August 2003.

48 Interview elder of Kontihene subchief of Beseasehene, 20 May 2003.

49 Interview royal family members Boankra, I8 December 2003.

50 As a chief's throne is called a stool, the installation and deposition of a chief are called 'enstoolment' and 'destoolment.'

5I Each village has its own Unit Committee, which forms the lowest level of local government in Ghana and is made up of 5-15 people per village.

52 Interview, I5 April 2003.

53 The District Assembly is the second lowest level of local government in Ghana. An assembly member is the representative of an electoral area in the assembly.

54 Interview former assemblyman Tikrom, I5 April 2003.

55 Interview former assemblyman Feyiase, 8 April 2003.

56 Interview Kontihene subchief of Beseasehene and one of the Konti elders, 20 May and I July 2003 .

57 The extent of local resistance is naturally correlated with the amount of land and the time-span in which chiefs are selling.

58 Interview Kontihene subchief of Beseasehene, I July 2003.

59 The position of both chiefs and councilors is hereditary in the sense that it has to be filled by a person from a certain - in the Ashanti Region usually matrilinear - family. Within such as family, there are usually a number of people eligible to fill the position, of which the family will choose the most suitable candidate. Besides hereditary councilors, a chief can also appoint a number of non-hereditary councilors on the basis of their personal merit. When such a councilor dies, the position disappears and the family will not be permitted to select a successor. See for a more elaborate discussion of election of chiefs and subchiefs Busia I951: 6-I3; Danquah I928: IIO; Hayford I970: 3 Kofi-Sackey I983: 66; Kumado I990-I992; Obeng I988: 34-45.

60 See also Hayford I970: 73; Pogucki I962: I82; Sarbah I968: 66, 87.

6I Interview, 28 October 2003.

62 Interview Unit Committee member Tikrom, 26 June 2003. Cf. Abudulai I996; Kasanga 1996.

63 Interview, 26 June 2003.

64 Interview Asantehene's Land Secretariat, 2 July 2003.

65 Interview Kontihene subchief Besease, I July 2003.

66 Section I5 of the Chieftaincy Act, I97I (Act 370), confers exclusive jurisdiction in any 'cause or matter affecting chieftaincy' - as defined at section II7 of the Courts Act, I993 (Act 459), i.e., an action concerned with the nomination, appointment, election of a chief or destoolment - to the Traditional Council or, if a paramount chief is involved, to the Regional Houses of Chiefs. From such a case an appeal lies to the Regional Houses of Chiefs, then to the National House of Chiefs and finally even to the Supreme Court. This means that one cannot take such cases to the regular state courts, only to the Supreme Court in the last instance. It must however be noted that the courts have not allowed for such a broad interpretation of the words 'cause or matter affecting chieftaincy' that the entire functioning of Traditional Councils falls outside their scope. For instance, 
land cases that are not concerned with the nomination, appointment, election or destoolment of a chief can be taken to the state courts.

67 Interview Kontihene subchief of Ejisumanhene, 27 May 2003.

68 See, for instance, interview elder of the Beseasehene, 5 June 2003.

69 Interview Gyaasehene subchief of Ejisumanhene, I June 2003.

70 Interview, 29 June 2003.

7 I Such as the chief's right to wild animal skins, tributes of fish, and communal work on his farm (Annor I985: 157; Busia I951: 44).

72 Interview Okyeame subchief of Beseasehene, I2 June 2003.

73 Article $270(2)$, I992 Constitution.

74 Interview Jachiehene, 29 June 2003.

$75 \mathrm{He}$ is, amongst other things, involved in the areas of education and health care.

76 Shortly after his enstoolment, the Asantehene commanded the withdrawal of land and chieftaincy cases from the state courts and the Regional House of Chiefs. These were to be brought to the Traditional Council for settlement. Although this is an understandable and sensible appeal, considering the enormous backlog in state courts, the move is also highly political as the Asantehene reclaims the traditional trias politica of legislator, administrator and judge.

77 A committee consisting of the heads of the thirteen divisions of the Kumasi Traditional Area has made a proposal to legislate land revenue sharing. This proposal, which was awaiting approval by the Asantehene when I left the research area in February 2004, proposes that the revenue from land allocations be divided as follows: a third to the Asantehene and two-thirds to the locality. This two-thirds would be further divided as follows: a quarter to the chief; a quarter to the stool; a quarter to the town; an eighth to the elders; and a further eighth to community members who lose land. Under this system, both the farmer and the town receive a part of the land revenues and the codification will probably enhance the accountability of chiefs: statements by the Asantehene on this issue are already being used as a resource in local struggles. The proposed legislation would be an improvement for some villages. On the other hand, in this system three-quarters of the revenues flows into the traditional system, whereas community members receive only a twelfth and the town a meagre sixth. One could wonder whether this is a fair distribution of revenue from communal land. When land revenue is distributed in such a way, the traditional system becomes a very expensive institution for villages.

78 For example, according to the Asantehene's secretariat, the Asantehene is supposed to get a third of the revenue from stool land allocations in the Kumasi Traditional Area. However, since most chiefs do not register their land sales, the secretariat has no way of knowing how much land the various chiefs have allocated. The Asantehene cannot therefore enforce this 'rule' and does not receive his share. The secretariat is trying to overcome this problem by asking not for a third of the revenue but for a third of the land when it is demarcated for development. Another example can be found in a dispute between the Asantehene and his Kaase stool over the right to allocate Kaase land. This shows that the Asantehene is trying to increase his influence on land in the Kumasi Traditional Area (Gyeabour II v. Ababio [I99I] 2 GLR, 4I6). The court ruled for the Kaase stool.

79 Articles 267 (I) and 36 (8), I992 Constitution.

80 S.B. Amissah, R.K. Kasanga and A.R. Edmundson, Report on Land Management in Ghana, Prepared for the Environmental Protection Council (I990): 34, quoted in Hueber and de Veer 200I: I9I.

8I Multiple sales of the same plot of land to several persons is a large and growing problem in peri-urban Accra, and is also described for peri-urban Kumasi (Edusah and Simon 200I; Oduro-Kwarteng 2003). 
82 Interview, 27 May 2003, confirmed by planning officer TCPD Kuntanase district, interview 7 April 2003.

83 Chiefs can have their land demarcated by unofficial surveyors who do not interfere with planning and which leaves open the possibility of later changes in the plan. Such amendments were frequently encountered during fieldwork. In a DFID-sponsored project 34 of the 37 villages in peri-urban Kumasi possessed village layout plans, but the majority of these plans was prepared without reference to the statutory agencies responsible for planning (DFID 200I: D8, EI3).

84 According to the law, the whole process of acquiring a building permit should not take longer than three months. But in 2003 the Ejisu-Juaben district had not seen a meeting of the Planning Committee in over two years (interview Director TCPD Ejisu-Juaben district, 27 May 2003).

85 Of 242 people surveyed in peri-urban Kumasi, II5 (47.5\%) had never heard of a building permit. The other $\operatorname{I27}(52.5 \%)$ had heard of it, but only 75 of them (31.0\% of the total) could actually explain what it is. When these same 242 people were asked whether they possessed any documents on the house, 85 answered yes, 83 no, and the other 74 said that they did not know. Of the 85 that answered yes, 48 did not know what kind of documents, 29 said they did not have a building permit and 8 said they did have a building permit. According to the deputy Regional Lands Officer of Kumasi, $87 \%$ of the people has no building permit and only I०\% of the people tries to get a formal lease (interview, 20 September 2005).

86 Interviews District Chief Executive Ejisu-Juaben district, 9 September 2003 and I2 January 2004 .

87 Interview District Chief Executive Ejisu-Juaben district, 9 September 2003.

88 See for instance Daily Graphic 25 August 2003: 3; Ghanaian Times 5 August, 2003: I, 25 August, 2003: 3 .

89 Section I5 (I), Chieftaincy Act, I97I (Act 370).

90 Interview co-ordinator of Land Administration Programme, I9 august 2003.

9I Interview, 3 December 2005 .

92 A long-term programme with multi-donor support, which started in 2003 with the objective "to develop a sustainable and well functioning land administration system that is fair, efficient, cost effective, decentralized and that enhances land tenure security" (Ministry of Lands and Forestry 2003: 12). See also Ministry of Lands and Forestry 1999: 99; World Bank 2003a. See chapter 2.

93 This includes revenue accruing from timber and mining concessions. See for instance Asante 2003: 9; Odeneho Gyapong Ababio II 2003: 3.

94 Daily Graphic 22 August, 2002: I7.

95 IAside from the courts that protect the usufructuary rights of community members in individual cases, see Ubink 2002-2004.

96 To some extent, state legislation and statements by state officials are also used as a local resource but in general claims are legitimized by referring to customary law.

97 According to a land official, "Chiefs coat their actions in custom" (Interview OASL Kumasi, 27 June 2003). Dr Adinkrah, a legal scholar and a chief himself, calls this "the prostitution of customary law by the chief" (Interview, 4 September 2003).

98 Ostrom, in her studies of such characteristics and institutions with regard to the management of common pool resources, mentions for instance collective choice arrangements - whether most individuals affected by the operational rules can participate in modifying them - accountable monitors, and the existence of powerful actors who can change the rules of the game to the detriment of the less powerful or block efforts by the latter to change the rules to facilitate more equitable outcomes (Ostrom I990: 90). 
99 As said above, Heller warns for the creation by governments of anticommons property through the recognition of multiple owners of land who are each endowed with the right to exclude others (Heller I998). 



\section{Negotiated or Negated? The Rhetoric and Reality of Customary Tenure in an Ashanti Village in Ghana}

Based on Africa (2008) 2, in press

Janine M. Ubink 



\section{Negotiated or negated? The rhetoric and reality of customary tenure in an Ashanti village in Ghana}

\section{Introduction: the negotiability of customary tenure}

Issues of equity and security in the governance of land and natural resources are of growing concern to scholars and policy makers, and the suitability of customary and state tenure systems to provide rights of access to land for the poor have been debated for many years. ${ }^{I}$ Whereas historically land tenure reforms in Africa have attempted to replace existing customary structures, a more pragmatic adaptive strategy of building on and reconfiguring customary law is now emerging (Bruce and Migot-Adholla I994; Cotula, Toulmin, and Hesse 2004: 5, 7; DFID I999: 7; Platteau I996: 76; Quan 2000: 38; World Bank 2003b). Notions of customary tenure as a pre-colonial code of fixed rules have recently been abandoned, in recognition of the evolution and flexibility of customary systems (Juul and Lund 2002b: 3; Shipton and Goheen I992: 308-II; Toulmin, Lavigne Delville, and Traoré 2002a; Woodhouse 2003: I7I2). Customary land tenure is now seen as a field where social and political relationships are diverse, overlapping and competing. Property regimes are thus often analyzed in terms of processes of negotiation, in which people's social and political identities are central elements that also become contested terrain (Berry 2002b; Juul and Lund 2002b).

Peters (2002: 46-7) identifies three basic positions in the literature with regard to the negotiability of customary tenure. The first argues that the ambiguity and negotiability of customary tenure leads to a pervasive insecurity of rights of producers and to a lack of investment and inefficient uses. The second position identifies the negotiability and ambiguity of relations over land as a reflection of defining features of African societies, such as the hold social relations have over economic action, the dependence of individual actors on social networks to gain access to resources, and malfunctioning states. The fact that people's access to land is closely linked to membership of social networks and participation in political processes is seen to open up possibilities of access to land for the poor and not as necessarily engendering insecurity and increasing inequality (cf. Berry I993: 104). The third view holds that the ambiguity and negotiability of customary tenure do not neces- 
sarily inhibit investment but lead to increasing inequality, because some people are in a better bargaining position than others and there are limits to negotiability and ambiguity (cf. Berry 2002b: 219; Woodhouse 2003: I705-6).

The first view was dominant from the ig6os to the I980s (Acock I962; Feder and Noronha I987; Yudelman I964) but it has now been largely abandoned. Scholars such as Platteau (2000), Toulmin and Quan (2000), and Toulmin, Lavigne Delville and Traoré (2002) now appear to favor the second position, although "with sufficient unanswered questions to leave open the possibility of accepting the third" (Woodhouse 2003: I706). Others such as Cousins (2002), Daley and Hobley (2005), Juul and Lund (2002), Lund (2000), Peters (2002), Shipton (2002) and Woodhouse (2003) support the third position based on mounting evidence of land appropriation by influential elites and increasingly restricted and insecure access to land (see, for instance, Abudulai I996; Downs and Reyna I988: I8; Simo I996: 49; Swindell and Mamman I990: I77). They point to the fact that negotiators or contestants in customary land matters seldom operate on level playing fields. Some have more negotiating power and more defining and contesting powers than others (Shipton 2002: X). When competition for land intensifies, the inclusive flexibility offered by customary rights can quickly become uncharted terrain where the less powerful are vulnerable to exclusion as a result of the manipulation of ambiguity by the more powerful (Woodhouse 2003: I7I5). Ambiguity offers room for manoeuvre to small farmers and modest rural producers, but at the same time is exploited by the privileged in order to obtain advantage (Peters 2002: 53). These studies also show that not everything is negotiable: "porous boundaries and fluid, malleable identities too have their limits. There are some groupings and roles to which humans get ascribed and from which they have no escape" (Shipton 2002: X).

This chapter studies the negotiability of customary tenure in peri-urban Ghana where land is at the centre of intense and unequal competition and closely tied to struggles over authority. The peri-urban village of Besease provides a grassroots view of processes of contestation of customary rights to land. The analysis of how local actors in this village deal with, negotiate, and struggle for land rights, confirms that these contestants always face an unequal fight. Postulating the social inequalities of local communities, the chapter analyses whether it is useful to place all local dealings about land under the term 'negotiations' which signifies a mutual interest of the parties, as well as an opt-out option if negotiations prove unsatisfactory ${ }^{2}$ - or whether such a characterization extends beyond the boundaries of the term and risks undercutting the significance of local stratification and ignoring the winners and losers of uncertain rules. 


\section{Land tenure in an Ashanti village}

\section{Ghana}

The evolution of customary tenure in Ghana has been described by scholars such as Alden Wily and Hammond (200I), Amanor (I999, 2001), Berry (I993, 2001, 2002), Boni (2006), Lentz (2006) and Lund (2006), who all differ in their terminology. While Berry, for instance, invariably stresses the flexibility and negotiability of customary tenure, Amanor (200I: I6) cautions that "defining the customary as flexible, adaptive, dynamic and hybrid creates problems for examining processes of change, since change has now become an intrinsic feature of institutions rather than a product of struggle between different social forces." They do agree, however, that property relations are subject to intense contestation in cases where access to wealth and authority are undergoing rapid change. In line with this observation, the current chapter focuses on a peri-urban area of Ghana where such changes are salient. Due to urbanization and population growth, peri-urban areas are witnessing a high demand for residential land, which is triggering struggles over the rights to allocate village land that has been cultivated by community members for residential purposes. In Ghana, the 'customary' dominates both property rights and allocational authority: $80 \%$ of land is regulated by customary law, ${ }^{3}$ signifying a decisive role for traditional authorities. ${ }^{4}$ In peri-urban areas this role is described as shifting "from stewardship to ownership" (Alden Wily and Hammond 200I: 96). Although stool ${ }^{5}$ land administration is largely the domain of the traditional authorities, the government is to a certain extent also involved in stool land administration, for instance through the collection and distribution of stool land revenue, the requirement to provide consent and concurrence for allocations of stool land, and through land use planning. ${ }^{6}$ However, in 2003 Ghana started a Land Administration Project, a long-term program with multi-donor support, under which the government would pass its responsibility for the management of stool lands to customary land secretariats under the aegis of the traditional authorities (DFID 2004; Ministry of Lands and Forestry 2003: I2). ${ }^{7}$ This project is expected to enhance the pivotal position of traditional leaders in Ghanaian land management. The lowest level of local government in Ghana, the Unit Committee, ${ }^{8}$ has no formal role in land management, but its members and the local representative at the District Assembly 9 are often actively involved in development of the community and are, as such, in dialogue with the chiefs about issues of land-use planning and land revenue expenditures.

The peri-urban village this chapter focuses on is in the vicinity of Kumasi. Besease used to be a village of subsistence farmers but with the growth of Kumasi it has become a popular residential area where land 
is a valuable asset, now selling ${ }^{\mathrm{IO}}$ for more than Cedis Io million (almost $€$ IO०O) per (residential) plot. Various actors - farmers, families, family heads, chiefs, the paramount chief, local government representatives, and 'foreign' or local buyers of residential land - are all struggling for land on the outskirts, and the revenues this can bring. Sometimes actors team up, in other struggles former allies become new enemies. The story of Besease opens small but meaningful windows onto local contestations for rights to land and serves to illuminate the capacity and opportunity of various local actors to negotiate their positions. It is based on fieldwork undertaken in 2003 and 2004. While the research displays narratives from only one village, it was part of a broader study in peri-urban Kumasi that has unveiled the same kinds of processes in other villages, and which is also confirmed in the literature on other peri-urban areas of Ghana (Abudulai 2002; Alden Wily and Hammond 200I; Berry 2002a; Gough and Yankson 2000; Kasanga and Kotey 200r; Maxwell et al. I998). ${ }^{\text {II }}$

\section{Besease}

Besease - whose name literally means 'under (ase) the Cola tree (Bese)' - is situated on the outskirts of Kumasi, the capital of the Ashanti Region of Ghana. The village is about $23 \mathrm{~km}$ from Kumasi on the main road to Accra, just after the town of Ejisu, which is home to both the District Assembly and the paramount chief, the Ejisuhene (ohene: chief). Besease is famous as the hometown of Yaa Asantewaa - the queenmother of Ejisu who led the fight against the British in 1900 in what was later called the Yaa Asantewaa War - and infamous as the place with the worse rumble strips on Accra Road. The royal family of Ejisu comes from Besease, which therefore is home not only to the Beseasehene (who serves the Ejisuhene as his Akwamuhene and Baamuhene subchief) and his Kontihene subchief but also to three other subchiefs of Ejisuhene: Kontihene, Kyidomhene, and Gyaasehene. The term 'chief' can be confusing as it is used to describe various levels of traditional leaders. This chapter features the Asantehene, the chief or king of all Asantes; the Ejisuhene, a paramount chief; the Beseasehene, a village chief; and a range of subchiefs of the paramount chief or the Beseasehene. All are referred to by the term 'chief.' The titles of subchiefs are not based on the names of their residence, as we saw for the Beseasehene and the Ejisuhene, but on their function. They either refer to the subchiefs' original position in the chief's army - for example, the Kyidomhene is the leader of the rear flank (Akpi: back, behind) - or their administrative function in the locality - for instance, the Baamuhene takes care of the royal cemetery (Baamu: mausoleum). Subchiefs function as the chiefs' councilors. The councilors of lower chiefs are 
called elders. Four of the five residing chiefs 'own' land in Besease, with the fifth ${ }^{\mathrm{I2}}$ 'owning' land in Ejisu (see figure I). Ownership of land is a complicated concept since the ultimate title of stool land lies with the community, usufructuary interests with individuals or families, and the role of custodian is allocated to the chief. This multi-layered customary set-up allows considerable space for struggles to capture the new value of land in peri-urban Kumasi. At the centre of these struggles lie issues of authority about allocating village land to outsiders for residential purposes and entitlements to the proceeds from such allocations. A related issue is whether allocation papers need to be signed by a chief and, if so, by whom and for what signing fee. These debates are taking place within communities and between the various levels of chieftaincy.

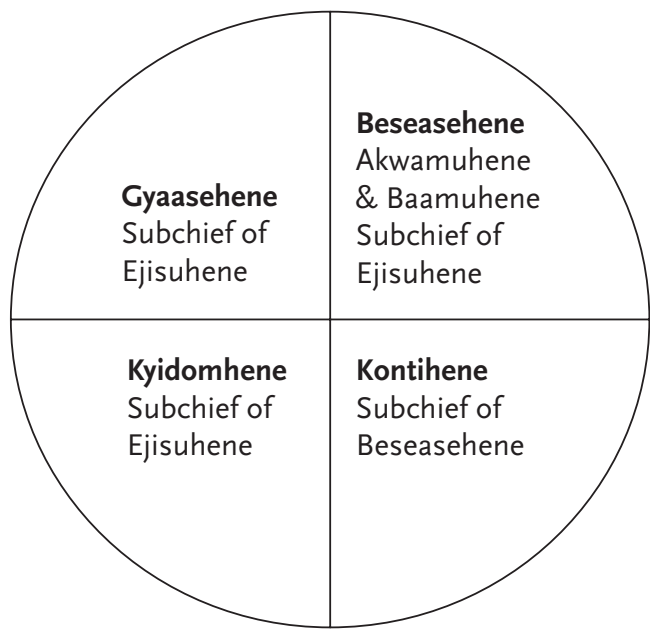

Figure 1: Land-owning chiefs in Besease

The paramount chief in the area of study is infamous for his style of land management, which lacks equity and pro-poor development. According to the assemblyman of Besease, "the Ejisuhene is a greedy man, therefore almost no one goes to him to sign the allocation papers, because he asks too much money." "I3 The area's District Chief Executive describes what he regards as the Ejisuhene's "autocratic way of ruling": "The Ejisuhene is leasing out land in the villages, bypassing the village chief. Therefore he tries to get subservient chiefs [in the villages]. Ejisu traditional area is notorious for its rampant chieftaincy disputes. The Ejisuhene is at the centre of those."I4 The Ejisuhene has also interfered with the selection of candidates for village stools in his traditional area. "The omanhene [paramount chief] is no good," says his Kontihene, "most of the chiefs he has planted in these towns are not liked." ${ }^{5} \mathrm{He}$ 
has, for example, interfered in the enstoolment of the current Beseasehene: "The Ejisuhene selected this person for the Besease stool. The kingmakers were not involved and the abusua panin [head of family] was even sent away at the enstoolment." "Similar practices were found in Boankra, Onwe, and Adadeentem, other villages in Ejisu paramountcy. The Ejisuhene also tried to destool a number of his own subchiefs, including the Kyidomhene, Gyaasehene, and Kontihene, because they did not agree with his land management. These depositions were not accepted by the families concerned, whose consent the Ejisuhene had failed to seek before taking action. The subchiefs for their part are bringing charges against the Ejisuhene on account of how much land he has sold, how little he has given to the Unit Committee during his ten-year reign and his unwillingness to account for his actions. The case is now before the Asantehene. ${ }^{17}$ "When this case has been settled, the local chiefs can also be dealt with," explains his Kontihene. "most of the village chiefs gave significant amounts of their revenue to the Ejisuhene, so it is actually the same case." ${ }^{18}$ In the meantime, the subchiefs are not going to the Traditional Council in Ejisu but are still carrying on with most of their functions in Besease. The relationship between the parties seems to have been soured. At a certain point, the Ejisuhene even reported his Kyidomhene, Gyaasehene, and Kontihene to the Regional Security Council for planning to assassinate him. However the council sent them home when they explained that they only wanted the Ejisuhene to account for his actions. "The Ejisuhene is now so afraid," sniggered the Kontihene subchief of the Beseasehene, "that even when he goes over the rumble strips in Besease his car goes at full speed because his Kontihene lives on the main road." 19 The ruined relationship means that the Ejisuhene cannot "come here and tell all the chiefs their different roles", as one of the villagers in Besease had hoped. ${ }^{20}$ Although there are doubts about the usefulness of his interference for community development because of his style of land administration, this villager justifiably wonders how local disputes involving chiefs can be solved when the paramount chief - who has the exclusive jurisdiction to deal with destoolment charges is unable or unwilling to discipline his subchiefs. ${ }^{2 \mathrm{I}}$

Due to its unusual set-up with four land-owning chiefs and a paramount chief who frequently interferes with village affairs, Besease offers four cases for studying agency and resistance in land struggles at various levels and in different arenas. These struggles can be grouped in three categories: struggles over the right to sell village land for residential purposes; over the right to sign allocation papers; and over the right to cash the revenue accruing from land sales. This division has been made to structure the land struggles in Besease but should not be interpreted as meaning that these rights are unrelated. For instance, 
the right to sign allocation papers entails a right to a negotiated signing fee and enhances the possibility of initiating sales.

\section{The right to sell}

The right to sell village land under cultivation by community members to outsiders for residential purposes is a highly contested issue in Besease. Does it belong to the farmers and families who have been cultivating the land for generations and passing it on to family members through gifts and succession? Or does it devolve to the chiefs who also have the right to allocate unused land to outsiders? According to the Beseasehene, "It is a law that when the town is growing and it comes to your farm, you do not have any land. Because the land is for the chief." 22 The Kontihene of the Ejisuhene agrees: "When the town reaches the farm, people lose their rights."23 "Only the chief can sell," says the Kontihene of the Beseasehene. However he takes a more moderate point of view: "you must compensate the farmer for his loss of livelihood if he approaches you with respect. How much? That depends on when the farmer is satisfied. You don't want trouble in the family. It's a process of negotiation." 24 Other villagers' views vary widely, from acknowledging the chief's right to sell the land to a full denial of any such right. "The chief decides to sell land. Farmers can't say no, but they can negotiate a price. But the bulk of the money goes to the chief, since he has full power" 25 is one view. While others feel that: "the chief cannot sell land without the family's consent because someone is farming there now. The money will go to the farmer, the chief only gets some of it." 26

In accordance with the conflicting statements described above, actions by both chiefs and the people demonstrate similar disagreements regarding land rights. ${ }^{27}$ The first case features the former Beseasehene who, at some point, demarcated a piece of farmland, which was being cultivated by a farmer from another family, into eight residential plots. The chief sold seven of these plots and gave the last one to the family concerned. The current Beseasehene recently sold the last eighth plot and the family was first aware of this when the buyer started to develop the land. A quarrel broke out between the chief and the family but the chief refused to give the family another plot, and "brought macho people in" 28 to restrain them. In contrast to this, the Beseasehene did not get his own way in a different case in which he sold a plot of land belonging to yet another family. As soon as the buyer started building on this piece of land, he was restrained by the infuriated family. The buyer then went back to the chief who approached the family to plead with them to settle the conflict, but they were adamant and the chief almost 
got beaten up. The chief then had to compensate the buyer. These two cases suggest that the power and actions of a family - depending on its size, connections, economic capital and willingness to act and use force - can influence the outcome of a chief's attempts to appropriate rights in family land. A last case involving a former Beseasehene dates back to I973, when $\mathrm{Mr} \mathrm{O}$. approached the Beseasehene about buying a piece of land on the other side of the road, near the station. After he had bought it, the land turned out to belong to the Kyidomhene. The two chiefs reached an understanding but $\mathrm{Mr} \mathrm{O}$. ended up with only a small part of the land he had bought, an outcome he felt unable to challenge. In this case, as well as in a number of other cases discussed below, it was the buyer who lost out.

A different chief, the Gyaasehene, wanted to sell some land, which in this case belonged to his own family. One of his predecessors had given a large tract of land to the Catholic church on the understanding that it would start a school on part of the land. When the Catholics failed to honor their promise, the current Gyaasehene approached the Bishop who returned part of the land to the chief. The Gyaasehene, instead of giving it back to his family, sold the land to outsiders and pocketed the proceeds. When the chief's family discovered his action, they initially wanted to destool him but this would have involved the Ejisuhene, with whom the family was still angry for his attempt to destool the Gyaasehene without their consent. Besides, the elder leading the charges was not on speaking terms with the Ejisuhene. This elder, a lawyer, had been the Gyaasehene-elect at the last installation, but the Ejisuhene had refused to enstool him, probably because in the past he had been involved in - and won - a court case against the Ejisuhene over land. After extensive deliberations, therefore, the family decided to keep the Gyaasehene on the stool but sent him away from Besease to avoid his meddling in land matters. This case demonstrates the danger a chief faces if he sells land that belongs to his own family, which has more direct power in disciplining the chief.

The next case shows that it is not only the chiefs who are selling land. A.D., a Kyidomhene elder, recently sold some plots of family land. According to him, he sold the land to raise revenue to renovate the family house, but his nephews claim that he sold more plots than was necessary for this purpose alone. When asked whether the chief's permission was required to sell land, A.D. replied that things were changing. "It depends on the animosity between the seller and the chief. The chief has to sign the land allocation paper and the site plan. But we first sell and then we go to the chief." ${ }^{29}$ He later explained that his family has three houses or 'gates' from which the Kyidomhene is selected, and the people from these three houses can sell their own land, whereas others cannot. ${ }^{3 \circ}$ When the Kyidomhene heard this, he 
stated angrily: "A.D. was wrong when he said that members of the three gates can sell their own land. He said that because he has sold seven plots." ${ }^{\text {II }}$ A.D. does not have a bad relationship with the Kyidomhene, however, because when the Ejisuhene tried to destool the latter, A.D., who is next in line to the Kyidomstool, refused the position. A.D. is thus not just any member of the family and he fully acknowledges that it "depends on your importance in the family" as to whether you can get away with selling your own land or can negotiate a fair price when the chief is selling it. ${ }^{32}$

The following cases show that commoners can also find ways to sell their land, although with some involvement by the Beseasehene. These cases centre on the interpretation of history. When the town started to expand during the reign of the former Beseasehene at the beginning of the I990s, the chief announced that anybody could sell the land he was farming. According to some, the Beseasehene's statement only referred to land belonging to his own family, while others took it to have a much wider meaning and to cover all the land in Besease. The Aduana family in Besease, who had been given farmland by the Kontihene subchief of the Beseasehene when they arrived in the village, seized the opportunity to sell their lands and went to the Beseasehene to sign the allocation papers, thus bypassing the Kontihene. The deal was of mutual benefit to the Aduana and the Beseasehene, since the first could sell their land without involving the Kontihene, while the latter could receive a Io\% signing fee on land that was not his. When the Kontihene discovered the sales, he wanted to take the Aduana to court but felt he could not do so because they were half-brothers and sisters. Besides this, "all the plots have been sold and the money squandered." 33 A similar story was told by the Kyidomhene:

"People with Kyidomland knew that I would not agree [to selling the land] and sign their allocation papers, so they went to the Beseasehene for a signature. When I heard about it, I could not do much about it. I called the people with a letter and sent a copy to the Beseasehene and Ejisuhene but I did not pursue it. I did not want to take my own family to court."34

These cases illustrate how, when chiefs are confronted with established sales, they do not always see the chance of reversing them to claim part of the revenue or to discipline the sellers in any other way, especially if the sale involves a larger group of people or the chief's own relatives. Both the Aduana family members collectively and a number of individual commoners with Kyidomland were able to sell their own land, with the signature of the former Beseasehene on their allocation papers. 


\section{The right to sign}

Whether the chief is the one to sell the land, or merely the one who signs the allocation papers, many people think that the chief has to be involved at a certain point. If a buyer wants to obtain a building permit from the District Assembly, his allocation paper will need to be signed by the chief, who will demand a signing fee for this service. A much debated question in Besease, however, is which chief needs to be involved. The Beseasehene posits that all allocation papers in Besease need his signature, whereas the other land-owning chiefs claim they can sign their own allocation papers.

"The king of Besease has overall power of the land," says the Beseasehene. "My uncle, the former chief, told the subchiefs they could sell their own land. But when I came, I cancelled that. I have to be consulted first. They are not happy about my decision. Some subchiefs sign their own allocation papers but it is risky to buy land without the chief's signature." ${ }^{35}$

The other chiefs protest this usurpation of power. "This chief pretends the other chiefs do not exist. He wants to own the whole town, which is not right," says one of them. "He is a small, new chief, he was only elevated to Akwamuhene in I975. His business is to mind the cemetery." According to the Gyaasehene, a purchase of land by the Beseasehene, before he became chief, supports this argument. This land was bought from the Kyidomhene who provided all the transaction documents without any involvement of the then Beseasehene. This is clearly not a struggle for signatures alone but for the power to control land sales and the revenue from them. "If we allow the Beseasehene to sign our allocation papers," says a Kontihene elder, "he will also try to initiate sales of our land and take the revenue." ${ }^{36}$

This dispute is tied up with the issue of authority. The Beseasehene claims that since he is the chief of Besease, he is superior to the other chiefs, at least regarding Besease lands. But according to the Kyidomhene and Gyaasehene, there is no hierarchical relationship. "Each chief pours libation on festive occasions," explains an elder of the Kyidomhene. ${ }^{37}$ Both claims are grounded in their own versions of history. In Beseasehene's version, two brothers named Asutwuma and Acheampong migrated to Besease from Denkyira. Later Asutwuma left for Eji$\mathrm{su}$, but since he originally came from Besease, he chose his subchiefs from there and asked his brother, the Beseasehene, to allocate land to these subchiefs and their families. As the Ejisuhene wanted to be buried in Besease, he created a royal cemetery there, which comes under the responsibility of the Beseasehene. This has earned him the addi- 
tional title of Baamuhene. Later, the Ejisuhene also made the Beseasehene his Akwamuhene, the divisional chief that speaks after the paramount chief. According to the other chiefs, the Ejisuhene, when he was still living in Besease as Beseasehene, divided land among his subchiefs as a reward for good service. The Gyaasehene, Kyidomhene, and Baamuhene received land in Besease, and the Kontihene in Ejisu. Later, when the chief left for Ejisu, he made the Baamuhene caretaker of Besease, while his higher divisional chiefs served him in Ejisu. The Beseasehene thus used to be only the Baamuhene, a 'service chief', of the Ejisuhene, and was elevated to Akwamuhene in the I970s, thereby gaining the same status as the Kyidomhene, Kontihene, and Gyaasehene. Even the Beseasehene's own subchief, the Kontihene, claims the right to sign his own allocation papers, and is in fact selling his land. "I am also the occupant of a black stool. I am next to him, not a subject. If the Beseasehene were cooperative, I would have advised the buyers to go to the Beseasehene with some drinks, but now he is trying to use power to take it." 38

Mirroring the conflicting statements above, actual dealings with land demonstrate various struggles as to who has the right to sign allocation papers. Two examples, in which the previous Beseasehene signed the allocation papers of land that fell under the jurisdiction of the Kyidomhene and the Kontihene subchief of the Beseasehene, respectively, have already been discussed. In both cases, the family members who were selling were reproached, but in the end the family members as well as the Beseasehene escaped unharmed. Even when the Beseasehene himself sold two plots of land belonging to his Kontihene in 2002, he did not run into trouble. "We, as the rulers of Besease, do not want to quarrel with him," explains an elder of the Kontihene, "but the buyer cannot come and work on it. If you come to work, you will meet the Konti."39 The Kontihene later added that he hoped that the buyer would take the case to court. As seen before, in the case of Mr. O., the buyer seems to suffer as a result of the malpractices of the selling chief. One should not conclude from the previous cases that the Kontihene recognizes any Beseasehene claims over his land or the revenue accruing from land sales. When the Kontihene recently sold thirty-two plots of land, the Beseasehene, as self-proclaimed overlord of the land, claimed Cedis 40 million (approximately $€$ 4000) of the revenue, but the Kontihene refused to pay even after the Beseasehene reduced his demand to Cedis 28 million.

Another inventive attempt by the Beseasehene to capitalize on his position proved equally unsuccessful. He personally went to the homes of all the people who had bought residential land from previous Beseasehenes, claiming that he should renew the signature on their allocation papers, a service for which he demanded a substantial signing fee. 
He went, for instance, to the house of Mrs O., who bought a tract of land twenty years ago from the then Beseasehene. He ordered Mrs O.'s mother, who lives in the house while her daughter lives in the BrongAhafo Region, to come to his house to get a new signature. But after consulting Mrs O. and her husband, she decided not to go. The chief also went to the house next door, where eighty-four-year-old Mrs A. told him that the papers were with her children in South Africa and that he had no right to see or sign them. A fight developed and insults were thrown by both sides. To another lady, Mrs S., he said that at the time of the sale, the land had been sold too cheaply and that he now had to sign the papers again. It was rumored that she had gone to the chief's house for his signature, and was made to pay Cedis I.2 million (approximately $€ \mathrm{I} 2 \mathrm{O}$ ), but during the interview she denied the story. "He is cheating us. I am not taking my papers there" was her firm response. ${ }^{40}$ Tellingly, the Beseasehene took no further steps to enforce 'his right' in these cases.

A comparison of the cases described in this section - where the house owners resisted the Beseasehene's claims for a renewed signature and his subchief, the Kontihene, refused to share revenue from land sales with him - with the cases in the last section shows that it is much easier to resist claims for money or a renewed signature than to fight an established sale. This demonstrates the crucial significance of the power to initiate sales. Whether this initiative is taken by commoners or chiefs, the other contestants are often unable or need a lot of force to undo any established sales or to claim part of the revenue.

\section{The right to cash}

In Besease, land struggles centre not only around the rights to sell and sign. Even when a chief has already sold land, the struggle continues for the right to cash or the obligation of the chief to set aside a certain part of the land revenue for community development. According to the Unit Committee (UC), the Beseasehene has sold many plots since his enstoolment at the beginning of 2002, but only in a few of these cases has he informed the UC of the sale and contributed Cedis 100,000 for community development. The other land-owning chiefs in Besease have neither disclosed sales nor contributed any money for community development. Since 2003, the UC and the assembly member have pressed for more transparency and funds for community development. After having been raised unsuccessfully in conversations with the Beseasehene, the issue featured prominently on the agenda of the 2003 Easter Convention: "We are going to tell the chief point blank to give money to the community", said the assemblyman a few days before 
the event. ${ }^{4 \mathrm{I}}$ This convention is a two-day homecoming event when everyone who comes from Besease, including the chiefs, get together for a celebration and a discussion of the town's affairs. To everyone's surprise, the Beseasehene and the queenmother did not attend this year. The general feeling was that they did not show up because the Beseasehene did not want to be questioned about his land administration policy. According to the Kontihene subchief of the Ejisuhene, "He did not come to the Easter Convention because I would bring him to account, and he has squandered all the money." 42 The people were so angry that they wanted to destool the Beseasehene, but when the queenmother apologized on his behalf they decided to give him one last chance. Their reluctance to destool him also seems to be based on fear because it is said that he uses juju and witchcraft. The other chiefs are also unable to introduce destoolment charges because of the dispute with the paramount chief regarding their own potential destoolment.

A few weeks after Easter, the UC and the assembly member called a village meeting at which they proposed to install a Plot Allocation Committee (PAC) that would sign all land allocation papers and secure a certain percentage of the revenue for community development. This provoked a heated debate between the Beseasehene, who denied all land sales, and the people who did not believe him and wanted him to account for his land administration. In the end, the Beseasehene reluctantly agreed to appoint two of his confidants to the PAC. The Beseasehene was the only chief present at this village meeting. The absence of the other chiefs was explained as being due to the animosity between the chiefs of Besease: "Every time they see the Beseasehene, they fight." 43 "Last meeting, a fight nearly broke out."44 "They have not been coming to public meetings because of their litigation with the Ejisuhene." 45 Since this meeting, the UC and the assemblyman have been trying to get all the chiefs together to agree to the PAC receiving a third of the revenue of all land allocations in Besease. According to the chairman of the UC, the Gyaasehene had already agreed but he had not yet spoken to the Kyidomhene. One of his elders did not think the Kyidomhene would agree "because a third is big money. But we will make him agree to a sizeable amount when we all meet. We have to convince them that the money will be used for the development of the town." ${ }^{46}$ Later interviews proved them right: the Gyaasehene stated that "The law that a percentage of land revenues should go to the town already existed, even if the chief didn't agree."47 But the Kyidomhene said: "It is too much because the farmer, chief, elders and stool also need money. Besides, the UC usually misuses the money. A quarter would be a better idea." 48 
During the following months, the Beseasehene proved to be the most uncooperative chief and tried to thwart any discussion on the topic. He seemed enraged by the refusal of the UC chairman and the assembly member to tell the other chiefs that all allocation papers should be signed by the Beseasehene. In an encounter shortly after the village meeting, the Beseasehene told the assemblyman and the UC chairman that since the community collects a third, they also had to take care of this issue. If they would not talk to the other chiefs, he would not comply with their laws to give a third of the revenue to the Unit Committee. But the assemblyman thought that the chief should give a third to the community because "the law is the law."49 At the end of August 2003, the PAC and all the chiefs finally met. The PAC explained that they wanted a third of all land proceeds for town development but the chiefs disagreed. "If your forefathers did not have land, you can't claim it now just because you are on the committee. The chiefs already pay more on certain occasions such as at the Easter Convention. And they pay a lot of expenses for their own families, such as education and funerals," the Kontihene of the Beseasehene later explained..$^{\circ}$ They promised to come up with a different proposal after discussing it amongst themselves. The PAC, however, never heard from them again. In January 2004 they sent all Besease chiefs a letter to ask them to account for their land administration, but this was also ignored. Even by September 2005, the PAC had still not started in Besease.

The configuration of Besease makes the coercion of chiefs in accountable land management and revenue sharing a complicated issue. None of the land-owning chiefs is eager to see a third of his revenue go to the community. As long as they can blame the failure on a third party, there is no incentive for them to try to reach an agreement. The Beseasehene is trying to use the installation of the PAC to initiate the practice of him signing all allocation papers in Besease. He blames the UC and the assemblyman for not cooperating with him and is therefore withholding his support for the PAC. The other chiefs are reluctant because of the same issue: they do not want to accept the Beseasehene as overall landlord and are unclear of the UC's position on the issue. Even farmers are taking an ambiguous stance towards the sharing of revenue from land sales. On the one hand, they would rather that revenues from land sales be used for community development than end up in the chiefs' coffers. But when they see the chance to sell their own land, they are not keen to hand over any of the purchase price to the UC. This constellation of bickering chiefs and wavering farmers makes it almost impossible for the UC and the PAC to take measures against reluctant chiefs. The situation is exacerbated by the fact that the paramount chief cannot be appealed to in a mediating role. In an attempt to break the deadlock, the PAC and UC members have turned to state 
law and statements by officials to underpin their claims. For instance, when the UC told the queenmother about the PAC, they said that the government had informed them that the community would get a third of any revenue from land sales. ${ }^{5 \mathrm{I}}$ And one of the PAC members claimed that "the subchiefs are all legally obliged to obey the law. It is a constitutional provision that the town receives thirty per cent of revenues. Even the MP when he came to the Easter Convention announced that." ${ }^{2}$ While the truth about official statements remains unclear, no such legislative provisions are to be found in the Constitution or elsewhere.

\section{Conclusion}

\section{Conclusions from the Cases}

This chapter has considered struggles for land regarding the right to sell, to sign, and to receive cash payments. The first conclusion that can be drawn from these cases is that selling land - sometimes initiated by farmers but more often by chiefs - is often profitable and does not entail many risks for the seller. Even if the land did not belong to the seller, sales were rarely reversed. And if they were, the seller was usually only made to return money to the buyer, which in the worst case sent the former back to square one, though without incurring additional costs. Even in the case of the Gyaasehene, who sold land belonging to his own family, the punishment was no more severe than his relocation from the village. The sale of land for residential purposes automatically implies the loss of farmland for a local farmer, which often severely affects the person's livelihood. Such effects are difficult to cope with or turn around if the sale of land provides good start-up capital for a new livelihood but become almost impossible to combat when the chief is the seller and provides limited or no compensation. Whenever a sale leads to a dispute between chief and farmer, the position of the buyer is also endangered. ${ }^{53}$ When a buyer acquires land from someone whose authority is questioned, which in Besease is more often the case than not, he runs the real risk of losing part or all of the land, of being threatened or assaulted by the aggrieved party, or of having to pay an additional sum either to acquire the same plot of land or as a signing fee for the allocation papers. ${ }^{54}$ The Beseasehene has even tried to make buyers from twenty years ago pay a new fee for their papers but due to their long-term uninterrupted possession of the land and the homes they had built on it, they withstood his pressure. In the triangle of chief, farmer and buyer, the chief usually benefits from land sales at the cost of the latter two which, over time, would ap- 
pear to result in reduced access to land for the poor and increased socio-economic inequality, a result confirmed by other research. ${ }^{55}$

Since selling land is profitable and those wishing to undo established sales are often unable to do so, gains largely depend on the opportunity or ability to initiate sales. Although we saw cases where commoners had been able to sell their land, the prime actors in selling land were usually the chiefs. Bruce (Bruce I988: 43) explains their strong position as follows:

"in many indigenous tenure systems a traditional leader who
administers community land is viewed as holding a tenure in
that land. This is best described as an estate of administration,
held in trust, but where the land is unoccupied and rights to
land are becoming increasingly individualized, the traditional
leader is sometimes able to convert the administrative estate to a
personal right."

In Besease, where there is no unoccupied land left, chiefs are even attempting to acquire personal rights over occupied land under cultivation by community members. The customary system of land allocation, with the chief as the administrator of land, is thus clearly dominated by the traditional elite. The chiefs' strong position is enhanced by their capacity to draw up planning schemes and demarcate village land into residential plots - actions frequently supported by local government which provides the administrative tools to allocate land.

Even though those who want land do not have equal opportunities, this does not mean that the powerful can deal with land as they please. Three cases described above showed how the Beseasehene overstretched his authority and was resisted. In the first case a family restrained a buyer from coming on to the land he had purchased from the Beseasehene and steadfastly refused to come to an agreement with the chief. The second case described how the Kontihene subchief refused to share land revenue with the Beseasehene. In the third case, the fierce resistance of various villagers against Beseasehene's scheme to 'renew' the signatures on old allocation papers was discussed. This chapter demonstrates that the stratification in Besease is more complicated than a simple opposition of chief-commoners. Just as there are various levels of chiefs, commoners do not form a homogeneous group but should be differentiated on the basis of their 'capital', such as their property, power, connections, and knowledge. It is likely that the chief's room for manoeuvre and the success of resistance against his actions depend among other things on the contestants' membership of social and political networks, their economic capital, the number of 
people they can mobilize, and the degree of physical force they are willing and able to use.

Among themselves, the chiefs of Besease constantly struggle for the spoils of land allocations. Besease, with its four land-owning chiefs, does not fit the typical model of an Ashanti village with respect to traditional leadership. The multi-chief configuration of Besease on the one hand offers opportunities for individuals and families to benefit from the animosity and rivalry between the chiefs, by playing them off against each other. On the other hand, it complicates the process of bringing about accountable land management and equitable revenue sharing, as was seen in the case of the establishment of a Plot Allocation Committee. ${ }^{56}$ Disagreements between the various chiefs in Besease and the interference of the paramount chief furthermore show how the local and the supra-local are intertwined, and illustrate how contestations over land are intimately tied up with struggles over political power and authority. Claims by an institution to define property are also claims about the institution's legitimacy itself (cf. Berry 2002b; Lund 2002). The Besease case furthermore shows that struggles both for land and political power, are intimately tied up with contestations of history.

In conclusion, this account of land struggles in Besease shows how sales of residential land have disproportionately benefited the traditional elite at the cost of small-scale farmers and stranger buyers. Customary tenure in Besease does not constitute a guarantee of security for the poor. This case therefore does not support recognition of customary rights at the community level per se as a means of protecting the poor. Since local communities are themselves "the sites of inequalities and the instigators of exclusions" (Moore I998: 42), measures to strengthen customary institutions and local control to access to land without regulating checks and balances on local power holders may actually reinforce inequality. Although this chapter covers only one village with its own peculiar composition, and other localities could well have different power configurations, the general trends described in Besease are confirmed by mounting evidence that, due to rising land values, processes of commodification and individualization of land are restricting access to land for the poor, increasing the appropriation of land by influential elites and exacerbating socio-economic inequalities (cf. Berry I988: 58-60; Downs and Reyna I988: I3-I9; Peters 2004; Woodhouse 2003: I7I7).

\section{A Conclusion on the Negotiability of Customary Tenure}

The third position described in the introduction to this chapter imputes the increased inequality under customary tenure to the differen- 
tiated bargaining positions within a community and the limits of negotiability and ambiguity. Although the Besease case endorses both these aspects, I agree with Peters (2004) and Amanor (1999) who warn that too much emphasis on negotiability results in an overestimation of people's agency and that the image of relatively open, negotiable and adaptive customary systems of landholding and land use obscures processes of exclusion, deepening social divisions and class formation. Peters, in a critical assessment of the literature stressing the negotiable and adaptive nature of customary tenure systems, simultaneously recognizes the valuable contribution of these studies to policy debates and points to a neglect in asking who benefits and who loses or, even when social inequalities are identified, to an undercutting of their significance by insisting on social agency:

"Critics who mounted successful challenges to simplistic and
economistic models that posited customary landholding to lack
security of title and, hence, to fail to provide incentives for in-
vestment and modernization, were able to reveal the fallacy of
this conventional development thinking, and, recently, to achieve
a dramatic reversal of position among World Bank researchers
and some aid agencies. But in so doing, they also have over-em-
phasized negotiability and indeterminacy, This, in combination
with a parallel shift in social theory influenced by postmodern
and postcolonial writing that privileges ambiguity, multiplicity
and indeterminacy, has resulted in a proliferation of studies cele-
brating agency and manoeuvres at the cost, I claim, of identify-
ing winners and losers." (Peters 2004: 27I)

In her opinion, more emphasis on who benefits and who loses in instances of 'negotiability' in access to land requires "a theoretical move away from privileging contingency, flexibility and negotiability that, willy-nilly, ends by suggesting an open field, to one that is able to identify those situations and processes (including commodification, structural adjustment, market liberalization and globalization) that limit or end negotiation and flexibility for certain groups or categories" (Peters 2004: 270) (emphasis added).

In line with, but perhaps surpassing Peters' observation, I wish to caution against misuse of the term 'negotiability.' As said earlier, the term 'negotiation' denotes a mutual interest by the parties as well as an opt-out option if negotiations prove unsatisfactory. ${ }^{57}$ Where neither of these characteristics are found in struggles and contestations for land because one party has the power to fully negate the other party's rights or to unilaterally impose a new constellation of rights, it is overstretching the term to continue to speak of negotiations. We cannot say that it 
is the result of a negotiation serving their mutual interest when a farmer finds out that a chief has sold his farmland. Nor can we speak of an opt-out option for this farmer when he goes to the chief to plead for part of the revenue. The Besease case shows a range of interactions on a continuum from I) negotiations where parties have more or less equal power, such as between chiefs, and 2) negotiations between parties with severely unbalanced power relations, such as between chiefs and poor farmers, to 3) unilateral actions where one party is presented with a fait accompli regarding an alteration in his/her rights to land but where resistance changes the outcome to a certain extent, and 4) unilateral actions where acts of resistance remain ineffective and the strongest party imposes a new constellation of rights or even negates all the rights of the other party. When Juul and Lund state that "just as poor and disadvantaged people may sometimes negotiate improvements to their lives, these may just as swiftly be negotiated away again", by using the word negotiation they present an incomplete and skewed picture that ignores a whole array of actions in which a powerful party one-sidedly abrogates or diminishes the other party's rights (Juul and Lund 2002b: 6). An overstretching of the term negotiation - or rather a continued use of the term when in fact negotiations have ended - is not only incorrect but also dangerous as it obscures the stratification of the local communities in which these processes take place, overemphasizing the positive aspects of customary tenure, while neglecting its injustices. This also sends a wrong signal to policy makers, who have mainly shifted from favoring the abolition of customary tenure systems (USAID I986; World Bank I975) to a greater role for customary land tenure (De Soto 200I; DFID I999; EU 2004; World Bank 2003b) but often still lack an eye for issues of social differentiation and inequality (cf. Daley and Hobley 2005: 4, 35). Overstretching the negotiability of customary tenure will sustain this gap between empirical realities of customary land tenure and its characterization in policy debates.

This research does not conclude that the increasing economic inequalities are solely or predominantly a consequence of customary tenure and negotiable land rights. Rather, these should be attributed to Ghana's political economy, with the internalization of the market-driven inequalities of the global economy and the strengthened position of chiefs that is discernable since the overthrow of President Nkrumah in I966, but especially pronounced during the current reign of President Kufuor. This research also does not mean to suggest that national legislation will necessarily make land management more equitable. It recognizes customary tenure as a fact of contemporary political life but warns about treating it as a panacea. The current strategy in international policy circles to build on customary law for the regulation of land tenure wrongfully assumes that customary law in practice pro- 
vides guidelines to ensure equity and security in the governance of land. We should "engage with "customary" tenure with open eyes" (Daley and Hobley 2005: 4, 35), and this warrants continued study and open debate into its functioning.

\section{Notes}

I A literature review can be found in Ubink 2007.

2 See Encyclopedia of Business and Finance; Law.com dictionary; Thefreedictionary.com; and Wikipedia, the free encyclopedia, all accessed I4 November 2006.

3 Land ownership in Ghana is classified in two categories: private land and public land. Around $20 \%$ of the land area is public land (see article 257 of the I992 Constitution), which falls into two main categories: land which has been compulsorily acquired for a public purpose or in the public interest under the State Lands Act, I962 (Act I25) or other relevant statute; and land which has been vested in the president, in trust for the landholding community under the Administration of Lands Act, I962 (Act I23). The remaining land in Ghana is private land that, apart from a small amount of common law interests, consists primarily of estates in customary communal ownership (Alden Wily and Hammond 2001: 46-8; Kasanga and Kotey 2001).

4 See articles 36 (8) and 267 (I) of the I992 Constitution.

5 Customary land is also called stool land, as the stool, the chief's throne, symbolizes the traditional community. The installation and deposition of a chief are called 'enstoolment' and 'destoolment.'

6 See Office of the Administrator of Stool Lands Act, I994 (Act 48I); Lands Commission Act, I994 (Act 483); Local Government Act, I993 (Act 462).

7 See chapter 2.

8 Each village has a Unit Committee made up of no more than fifteen persons, of whom ten are elected in non-partisan elections and five are appointed by government following consultations with traditional authorities and other interest groups.

9 District Assemblies (DA) are the political and administrative authorities in the district. Elections for DAs have been held since I988. $70 \%$ of the members of the DA are elected on a non-partisan basis, but the District Chief Executive - the single most powerful local government position that dominates district level government - and the other $30 \%$ of members of the DAs are appointed by the President in consultation with traditional authorities and other interest groups. Each assembly member represents one or more villages at the DA.

Io Although the Constitution (article $267(5)$ ) prohibits the sale of customary land and only allows leases, nearly everyone talks about the 'selling' of land and many people, 'sellers' as well as 'buyers', seem to regard land allocations for residential purposes as definitive transfers. The allocation papers that I saw during my field research merely stated that plot $\mathrm{x}$ was allocated to person $\mathrm{y}$, and did not mention the word lease or specify how long the allocation would be valid for.

II A detailed analysis of struggles for land in peri-urban Kumasi and a literature review of land management in peri-urban Ghana can be found in Ubink 2008, forthcoming.

I2 The Kontihene subchief of the Ejisuhene.

I3 9 May 2003.

I4 DCE Ejisu-Juaben, 9 September 2003.

I5 27 May 2003.

I6 Id.

I7 In September 2005, the case had been called four times and was still pending. 
I8 27 May 2003.

I9 I July 2003.

20 KK, 29 May 2003.

2I There are two underlying factors in the discord between the Ejisuhene and his subchiefs. First, the Ejisuhene was one of the very few prominent supporters of Rawlings' NDC government in Asante, and was (and is) widely disliked for that reason by his Kufuor's NPP supporting subchiefs. Second, the Besease chiefs have a particular historical reason for detesting Ejisu, as Ejisuhene Kwasi Afrane Kesi in the I88os dug up the royal cemeteries in Besease to seize the gold grave goods to finance his military support in the civil war that brought his 'client' Agyeman Prempeh to the Golden Stool as Asantehene in 1888 .

22 II May 2003.

2327 May 2003.

24 I July 2003.

25 PKA, I9 May 2005

26 KM, I6 May 2003.

27 According to authoritative interpretations in case law, the usufructuary interests of indigenous farmers and families on their land can be extinguished only through abandonment, forfeiture or with consent and concurrence of the interest holder. The usufructuary cannot be deprived of any of the rights constituting the interest, not even by the chief. This would seem to exclude the possibility of chiefs converting and selling subjects' farmland without their consent. It is less clear whether the usufructuary him/herself could convert his/her own farmland to residential land. It is thought that he/she needs to 'inform' the chief of any intentions to do so but it remains ambiguous as to whether it should be done before or after the conversion, whether this merely means informing the chief or whether it involves the chief's consent and, if so, on what grounds a chief could withhold his consent. Obviously these issues determine a chief's bargaining position regarding revenue from the land involved. See for an analysis of customary land law in the Ghanaian courts and a comparison with peri-urban practices, Ubink 2002-2004.

28 Assemblyman, I4 April 2003.

297 May 2003.

307 May 2003.

3I I9 June 2003.

3222 May 2003.

33 I July 2003.

34 I9 June 2003.

35 II May 2003.

36 WK, elder Kontihene subchief of Beseasehene, 20 May 2003.

$37 \mathrm{AD}, 7$ May 2003.

38 I July 2003.

39 WK, 20 May 2003.

4029 May 2003.

4I I4 April 2003.

$42 \quad 27$ May 2003.

43 Assemblyman, I2 May 2003.

44 UC member JB, I9 May 2003.

45 AD, elder Kyidomhene, 22 May 2003.

46 Id.

47 I June 2003.

48 I9 June 2003.

49 I2 May 2003. Despite this confident statement, such legislative provision does not exist. 
50 2I October 2003.

5I Queenmother, 29 May 2003.

52 KK, 29 May 2003.

53 Buyers are also in a vulnerable position due to the many illegal double or multiple sales of plots of land to different buyers.

54 Due to a number of factors in the wider political arena, buyers often do not see many possibilities to stand up for their rights: court cases are expensive and take many years; there are no other state institutions that offer any redress; and they often do not want to anger the chief since they are dependent on him if they still want land in the same locality.

55 This was confirmed during field research in eight other villages in peri-urban Kumasi, see Ubink 2008, forthcoming and by literature on peri-urban Ghana (Abudulai 2002; Alden Wily and Hammond 200I; Bassett I993: I7; Berry 2002a; Edusah and Simon 200I; Hammond 2005; Kasanga and Kotey 200I; Kasanga and Woodman 2004; Maxwell et al. I998).

56 According to Edusah and Simon (200I) attempts to install a PAC are thwarted by the chief in many other localities.

57 See note I23. 
Traditional Authority Revisited: Popular Perceptions of Chiefs and Chieftaincy in Peri-Urban Kumasi, Ghana

Based on Journal of Legal Pluralism (2007) 55, in press

Janine M. Ubink 



\section{Traditional authority revisited: popular perceptions of chiefs and chieftaincy in peri-urban Kumasi, Ghana'}

\section{Introduction: maladministration of land and popular perceptions of chieftaincy}

In Ghana, a large proportion of the land is so-called 'stool land', land vested in a stool ${ }^{2}$ - a customary community - on behalf of and in trust for the subjects of a stool in accordance with customary law and usage (articles 36 (8) and 267 (I), I992 Constitution). Traditional authorities are regarded as custodians of such land. In peri-urban Ghana, however, chiefs are displaying a tendency to adopt landlord-like positions with regard to customary land. They are rapidly converting farmland into residential land, displacing poor and marginalized families from their land. Along with their land, these families are losing their jobs and income base (Abudulai 2002: 72; Alden Wily and Hammond 2001: 44, 69-73; Berry 2002a: I24; Kasanga and Woodman 2004: 204-212; Kenton 1999: 31; Maxwell et al. I998; Toulmin and Longbottom 200I: iiiii, 30; Ubink 2008, forthcoming). These occurrences cause considerable unrest and distress in the communities. Since claims of an institution to define property are also claims to the institution's legitimacy itself (Lund 2002: 14; Shipton 2002: xi), the often criticized role of chiefs in the conversion of farmland can be expected to affect popular perceptions of chiefs and their various functions and as a consequence have a bearing on the institution of chieftaincy.

\section{A renewed interest in chieftaincy}

Popular views on chiefs and chieftaincy are acutely relevant since African governments, international institutions, and donor countries are displaying a renewed interest in chieftaincy. Whereas many post-independence African governments saw chiefs as impediments to modernization and nation-building and tried to curtail their role in local government and national politics (Kyed and Buur 2005: I; Sharma 1997: 40), ${ }^{3}$ since the I990's a large number of African countries have enhanced or formalized the position of their chiefs (Englebert 2002; Kyed and Buur 2005: I; Ray 2003b: II; Sklar 1999), including Mozambi- 
que, ${ }^{4}$ Uganda $^{5}$ and South Africa. ${ }^{6}$ In Ghana the Constitution 1992 guarantees the institution of chieftaincy (article 270) and recognizes the role of chiefs in customary land management (article 267). The position of the chiefs is currently being strengthened by the Land Administration Project, a donor sponsored, long-term program which aims to enhance land management in Ghana through the strengthening of customary land secretariats (Alden Wily and Hammond 200I; Ministry of Lands and Forestry 2003; World Bank 2003a). Traditional authorities also feature high on the agenda of international organizations and fora. A case in point is the World Bank's 'Promoting Partnerships with Traditional Authorities Project' in Ghana. Under this project the World Bank provides a US\$ 5 million grant directly to two traditional authorities in Ghana, the Asanteman Council and the Akyem Abuakwa Traditional Council, bypassing the Ghanaian government. The project aims to enhance the standards of health and education in the traditional areas, and includes the goals of strengthening the capacities of traditional authorities and upgrading the financial and management capabilities of the traditional councils and their secretariats (World Bank 2003c). Many African conferences also deal elaborately with the issue of traditional authorities, ${ }^{7}$ and delegations of traditional authorities are regularly received by foreign governments or politicians on their travels abroad. (Otumfuo Osei Tutu II Education Fund n.d. lists recent visits by the Asantehene).

Some authors explain the renewed interest in chieftaincy from the functioning or malfunctioning of post-colonial states. One of these explanations is connected to notions of 'failed states', unsuccessful nation-building and internal conflicts and civil wars, and poses the idea that chiefs have filled the gap of collapsed states (Kyed and Buur 2005: 2). Englebert (Englebert 2002: 57) however shows that the African continent displays a surprising lack of resurgence of tradition in collapsed or failed states. Rather, the revival of traditional authorities takes place in countries with a functioning state apparatus, alongside the establishment of competing local institutions in the form of democratically elected councils. ${ }^{8}$ The adoption of multi-party democracy and democratic decentralization, and the trend to consider the state as just another actor in an increasingly complex and interwoven global order, seem to have opened new public spaces for traditional leaders (Englebert 2002: 59; Kyed and Buur 2005: 3; National Democratic Institute for International Affairs I995; Oomen 2002: 8). In a comparable way, the liberalization policies of the I990s and donor calls for structural adjustment, emphasizing a smaller state, cuts in public expenditure, a strengthening of civil society, and alternative dispute resolution, created an increased space for the involvement of traditional authorities in law enforcement, dispute resolution, service provision, and the implemen- 
tation of development projects. Added to this the enlarged distance between people and the state facilitated the resurgence of tradition as an alternative mode of identification (Dañino 2005: I; Englebert 2002: 6o; Kyed and Buur 2005: 3-4; National Democratic Institute for International Affairs I995; Ntsebeza 2005: 2I-22). ${ }^{9}$ An enduring theme in chieftaincy literature is how chiefs have over time tried to secure and strengthen their position vis-à-vis the state, and have tried to capture public spaces opened up by new political constellations at the national or international level (Mamdani I996; Oomen 2002; Rathbone 2000; Ray and Reddy 2003; Van Rouveroy van Nieuwaal I996; Van Rouveroy van Nieuwaal and Van Dijk I999; Vaughan 2000).

Other explanations for the renewed interest in chieftaincy are rather linked to the realization of the various functions traditional authorities can perform and have been successfully performing in their areas. Prominent among these tasks are law enforcement and dispute resolution. Customary courts are said to be popular and often resorted to as they are easily accessible, cheap, fast, and comprehensible (Boafo-Arthur 200I; Boafo-Arthur 2003: I47; Dañino 2005; Lowy I978; Lutz and Linder 2004: 38; National Democratic Institute for International Affairs I995: 4-6; Ray and Van Rouveroy van Nieuwaal I996: 32; Sharma I997: 4I; Sharma 2003: 26I; Von Trotha I996: 84). For instance, in I997 customary courts in Botswana tried about 75 or $80 \%$ of the criminal and civil cases in the country (Sharma 1997: 4I). Another task often mentioned is the promotion of community development programs. Traditional authorities are often seen as having the capacity to mobilize their people behind development initiatives and to be able to use the authority and respect from their people for community education and awareness creation. Combined with the intimate knowledge they possess of their areas, this pleads for the inclusion of chiefs in community development processes, with the chief as a middle-man between the people and the government, bridging the often noted gap between state and society. Donors, aid agencies, and governments often look upon traditional authorities as the missing link between rural citizens and the state. On the one hand they are able to implement governmental law and policy and to facilitate, explain, and attain popular support for development projects in their traditional area, on the other hand they can provide information from the locality.

More generally, traditional leadership is seen as a channel that can articulate the needs and priorities of communities which it represents, and this can lead to genuine democratization and development and the assertion of local autonomy against the globalizing and modernizing power of the state. It is even claimed that reliance on chiefs in governance will reduce transaction costs and facilitate collective action (BakoArifari I999: 2I; Englebert 2002: 60; Hagan 2003; d'Engelbronner- 
Kolff, Hinz, and Sindano I998: XII-XIII; Keulder I998; Kyed and Buur 2005: 4; Lutz and Linder 2004: 38-9; National Democratic Institute for International Affairs I995: 7, I5; Omoding-Okwalinga I984; Ray, Sharma, and May-Parker I997; Ray and Van Rouveroy van Nieuwaal i996: I, 7; Sharma I997: 42; Sharma 2003: 26I; Thornton 2003: I27; Vaughan 2003: I72-4; Von Trotha I996). Many African governments also try to bridge the gap between government and civil society and strengthen the position of national government by integrating the sphere of tradition into the space of governmental power as a symbolic, legitimizing resource. Governmental leaders for instance frequently use external traditional features such as traditional regalia, titles, symbols, and myths (Lentz I998; Van Rouveroy van Nieuwaal i996: 43-4, 54; Von Trotha I996: 87-88). Traditional authorities also have a role to play in the field of natural resource management. They are thought to be able to ensure nature conservation and environmental equilibrium and to manage customary land in such a way as to ensure general and equitable access to land and to guarantee the social security function of land (Appiah-Opoku and Mulamoottil I997; Daneel I996; Hinz 2003: I046; Lutz and Linder 2004: 38-9; Sharma I997: 42; Van Dijk and Van Rouveroy van Nieuwaal I999: 6).

In performing all these functions, traditional leadership is also expected to protect local culture, tradition, identity, and religion (BoafoArthur 2003: I27; Ray 2003a: 92; Thornton 2003: I27; Von Trotha I996: 86). In general, however, the more symbolic - religious, spiritual, and ritual - elements of traditional authorities are rarely connected to the renewed interest in chieftaincy from African governments, donor countries and international organizations.

\section{Investigating popular perceptions of chieftaincy}

Both explanations for the renewed interest in chieftaincy - the opening up of new public spaces and the successful performance of various functions - pay hardly any attention to how the people feel about the chiefs, their performance, and the institution of chieftaincy. In fact, such data are hardly found in any research on chieftaincy. Oomen's study is a positive exception to this rule (Oomen 2002); a first approach towards such a study is also found in Crothers (Crothers 2003). This lack of data does not, however, hinder some academics and policy makers from making assumptions about popular views on chieftaincy, ranging from continued uncontested allegiance to the institution of traditional leadership to a complete loss of legitimacy by the chiefs (Lutz and Linder 2004: 3; Ray 2003b: 5; cf. Oomen 2002: I82). Empirical research on people's perceptions could make a valuable contribution to a 
more grounded and probably more nuanced picture of the role and position of chiefs and the institution of chieftaincy, and thus serve as useful input for national and international policy makers.

The present chapter hopes to contribute to chieftaincy literature by combining a critical discussion of chiefly rule with empirical data on popular perceptions on chiefs and chieftaincy. It is based on extensive qualitative and quantitative field research ${ }^{10}$ conducted from 2002 to 2005 in nine peri-urban ${ }^{\text {II }}$ communities around Kumasi, Ghana. It also makes use of survey data collected by Crook et al. on dispute settlement institutions in the same area (Crook et al. 2005). Based on these data, it will demonstrate that people's support for the institution of chieftaincy does not need to imply their satisfaction with chiefly performance. Formal recognition of chiefs by African governments and cooperation of international institutions and donor countries with chiefs should therefore be preceded by a critical assessment of chiefly rule. And if the assessment shows that certain functions are not performed satisfactorily according to the people the recognition should be combined with the imposition of checks and balances on the functioning of chiefs in general or with the regulation of certain fields in particular.

Kumasi is the second largest town in Ghana and the capital of the Ashanti Region. Chiefs are a prominent feature of Ghanaian society. The Constitution 1992 guarantees the "institution of chieftaincy, together with its traditional councils as established by customary law and usage" (article 270 (I)). Article 270 (2) stipulates that parliament cannot interfere in the recognition process of chiefs. This power lies exclusively with the Traditional Councils and Houses of Chiefs, aside from the possibility of a final appeal to the Supreme Court (articles 273-74 of the 1992 Constitution and sections I5, 22, 23 of the Chieftaincy Act I971, Act 370). The National and Regional Houses of Chiefs furthermore act as advisory bodies to the state, discuss traditional social practices, and give official recognition to chiefs. According to Toulmin and Longbottom (Toulmin and Longbottom 200I: II-I8) chiefs have remained of much greater importance in Ghana than elsewhere in West Africa. ${ }^{\mathrm{I} 2}$ The traditional leadership position in Ghana is becoming more competitive than ever before and is attracting academics, civil servants, business leaders, and teachers (Brempong 2001: 59, 60; Toulmin and Longbottom 200I: I2; Otumfuo Osei Tutu II 2004; Ray I992: III-3). In the Ashanti Region chiefs are highly visible and organized strongly hierarchically, from the Asantehene, king of Asante, at the top through the paramount chief (omanhene), divisional chief (ohene) and local village chief (odikro) to the clan or family head (abusua panin).

This chapter is structured around the main functions of the chief according to the 242 people surveyed in peri-urban Kumasi (Table I). These functions are categorized under four headings: I) land manage- 
Table 1 What are the main functions of the chief?

\begin{tabular}{lr}
\hline Main functions of chief & $\%$ \\
\hline Dispute settlement & 78.1 \\
Ensuring community participation in development & 59.1 \\
Ensuring peace in the community & 53.0 \\
Looking after the physical development of the town & 50.0 \\
Land management & 43.8 \\
Organizing communal labor & 27.7 \\
Celebrating traditional festivals & 8.3
\end{tabular}

(Note Most people in the peri-urban communities studied referred to their villages as towns.)

ment; 2) local development projects, encompassing ensuring community participation in development, looking after the physical development of the town and organizing communal labor; 3) law and order, comprising dispute settlement and ensuring peace in the community; and 4) traditional religion. In the section on land management people's opinions on and resistance to chiefly land conversions will be presented. In the three following sections chiefly rule and popular perceptions on it will be analyzed in the fields of local development projects, law and order, and traditional religion.

The functions mentioned under local development projects also fall within the realm of local government. In Ghana, District Assemblies (DAs) are the political and administrative authorities in the district: they exercise deliberative, legislative, and executive functions and supervise all other administrative authorities in the district. The legislative instruments setting up each DA provide a very specific list of up to

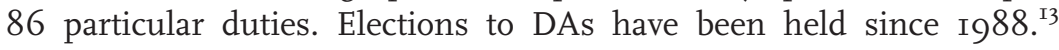
With regard to land management, the making of by-laws with respect to building, sanitation and the environment, the preparation and approval of planning schemes, the granting of building permits, and the enforcement of regulations and sanctions for non-compliance all rest with the DA (Kasanga and Kotey 200I: 9).

Quite recently the DA structures have been supplemented by Unit Committees (UCs), which are to function as the base structure of Ghana's local government system. They perform roles such as public education, organization of communal labor, revenue generation, and registration of marriages, births, and deaths. They have no official role with regard to land management. UCs consist of not more than I5 persons, of whom Io are elected in non-partisan elections and five are government appointees. The appointments are made after consultation with traditional authorities and other interest groups. The UC's viability has been questioned on the basis of lack of financial and administrative backup (Ayee I999; Crook I99I; National Commission for Civic Educa- 
tion I998; USAID 2003: 30-I). The first UC elections were held in I998. Villages in peri-urban Kumasi thus each have their own UC, and every one to three villages elect a representative for the DA. In the section on local development projects the relationship between the activities of chiefs and local government will be taken into account.

In the final section people's assessments of the institution of chieftaincy will be discussed and a conclusion drawn on the correlation between the performance of chiefs and popular perceptions of the institution of chieftaincy.

\section{Land management}

In peri-urban Kumasi farming is still a major occupation. In the eight villages surveyed, farming was the main occupation of $31.8 \%$ of the people, and an additional $25.6 \%$ farmed besides carrying on another occupation. The number of people still depending wholly or partly on farming varied widely between the villages, depending mainly on the distance to Kumasi. This is illustrated in Table 2, which displays four of the surveyed villages that lie quite close to each other on the road from Kumasi to Bekwai, with the nearest one approximately ten kilometers out of the city centre. This table reveals that in the village closest to Kumasi, Ahenema Kokoben, farming has lost its importance.

As said above, the peri-urban interface is characterized by a rapid conversion of farmland into mainly residential and some industrial or commercial land. In response to a question asked to the I7I people that were either still farming themselves, or whose family members in the village were still farming $58.5 \%$ stated that they or their farming family members had less farmland than ten years ago. In Ahenema Kokoben the population has increased from 302 in I984 to 3400 in 2000 (GSS 2002). It is the chiefs who are the main actors in the conversion process. They claim the right to convert land which is being farmed by community members - and often has been farmed by the same family for generations - to residential land and to allocate this land to outsi-

Table 2 Percentage of farmers compared to distance to Kumasi

\begin{tabular}{lccc}
\hline Name of village & $\begin{array}{l}\text { Rank in distance } \\
\text { to Kumasi } \\
(\mathbf{1}=\text { close, } \mathbf{4} \text { = far) }\end{array}$ & $\begin{array}{l}\text { People who farm } \\
\text { as their main } \\
\text { occupation (\%) }\end{array}$ & $\begin{array}{l}\text { People who } \\
\text { farm besides } \\
\text { other job (\%) }\end{array}$ \\
\hline Ahenema Kokoben & 1 & 3.3 & 6.6 \\
Brofoyeduru & 2 & 23.3 & 26.7 \\
Kotwi & 3 & 23.3 & 40.0 \\
Nkoranza & 4 & 50.0 & 16.6 \\
\hline
\end{tabular}


ders. ${ }^{\text {I4 }}$ From the chiefs' perspective, it is understandable that they make an inroad into people's usufructuary rights. Since there is almost no vacant communal land left in peri-urban Kumasi, it is the only way to make money from the land. But the consequences of the conversion are drastic for most people. There are clear links between land conversion and increasing insecurity and poverty: some people become wealthier, but farmers and families who lose their land without appropriate compensation become poorer and in time lose the basis of their livelihood strategies. They are no longer able to grow their own food and generate some income by selling the surplus at the market. Many of the poorly educated farmers become jobless or resort to petty trading.

This description of chiefs' dealings with land, and the local consequences, brings us to the question of how people in the villages regard these actions. It has been put forward that people in the villages generally accept that the development of residential plots is primarily the chief's concern (NRI (Natural Resources Institute) and UST (University of Science and Technology) I997: 23). Others claim the opposite, i.e., that most people in peri-urban Kumasi want to minimalize the role of the chief in land administration (Van Leeuwen and Van Steekelenburg I995: 59). In the current research, the chiefs' claim that they can allocate farmland to strangers for residential purposes was accepted by 56.I\% of the surveyed population (Table 3).

Acceptance was high in the villages of Jachie, Tikrom, and Ahenema Kokoben. One might expect that this acceptance stems from the fact that in these villages the chiefs are using the land and the revenue accruing from the conversions in the best interest of the community. Indeed, the Jachiehene ${ }^{15}$ for instance allowed members of the community to buy residential land at a very low price. And the revenue generated by leasing the remaining residential plots to outsiders was used for community development. In the first four years of his reign, the Jachie-

Table 3 Who can allocate farmland to strangers for residential development?

\begin{tabular}{lccc}
\hline Name of village & Village chief (\%) & Head of family (\%) & Farmer (\%) \\
\hline Jachie & 100.0 & 0.0 & 0.0 \\
Tikrom & 91.3 & 4.3 & 4.3 \\
Ahenema Kokoben & 72.7 & 4.5 & 13.6 \\
Adadeentem & 53.8 & 15.4 & 26.9 \\
Nkoranza & 47.6 & 28.6 & 14.3 \\
Kotwi & 33.3 & 13.3 & 40.0 \\
Boankra & 33.3 & 40.7 & 22.2 \\
Brofoyeduru & 20.0 & 15.0 & 50.0 \\
Total & 56.1 & 13.5 & 24.0 \\
\hline
\end{tabular}

(Note: Only the three most quoted categories are represented 
hene has built a library, a school, and a palace, and has allocated part of his land to a Technical School in exchange for scholarships.

However, same cannot be said for the chiefs of Tikrom and Ahenema Kokoben. In these villages chiefs reallocated large amounts of farmland without proper compensation and hardly any revenue was utilized for community development. The high percentage of people accepting the power of the chief to reallocate their farmland in the three villages can perhaps be understood rather as an acceptance of the reality of daily life. For in all three villages the chiefs not only claimed the right to allocate their farmland to strangers, but have also effectuated this right. Although most people in these villages accepted that the chief converted farmland, his right to spend the revenues at will was challenged. There was a lot of individual and communal resistance against the way chiefs used the revenues and against non-compliance of chiefs with planning schemes and environmental rules. Thus in Tikrom a long process of talks and consultations took place between chief and community. First, at a range of village meetings the people requested a substantial percentage of land revenues for community development. When this proved unsuccessful, the people tried to involve the chief of Asomenya, their place of origin, who refused to get involved. As the Tikromhene directly comes under the Asantehene, the former assemblyman (the member of the DA who represented the village) wrote a petition to the Asantehene in May 2002, but the case has not been called before the Asantehene so far. The same assemblyman has also brought in the Environmental Protection Agency (EPA) to investigate the chief's sand mining close to streams. The EPA criticized the chief's actions, but the power to prosecute lies with the DA, which did not act upon it. The assemblyman furthermore discussed the problems at a local radiostation and again appealed to the Asantehene for help, but this also has had no effect.

In the other villages studied, either not so much land was converted yet, or the people were themselves highly involved in land allocations. For instance in Boankra, the stool has been vacant for many years due to a chieftaincy dispute, and families have been allocating their land to outsiders independently of the chief's family. And in Brofoyeduru, local farmers are converting and selling their own land, after which they direct the buyer to the chief who will sign the allocation papers for a moderate signing fee. Although the Constitution prohibits the outright sale of stool land, which can thus officially only be leased, nearly everyone speaks of the selling of land and many people, 'sellers' as well as 'buyers', seem to regard the allocations as definitive transfers.

Considering the severe effects on their livelihoods, it is understandable that people undertook various actions to influence the way revenues are spent or even to prevent the reallocation of their farmlands al- 
together. All villages studied witnessed various kinds of ongoing struggles and negotiations between the land-owning chiefs and their people. Acts of resistance ranged from direct interactions with the chief - to plead, convince or strike a deal with him - to actions circumventing the chief. Examples of this last strategy are: selling your own land before the chief does it, or restraining a buyer, who purchased land from the chief, from entering the land or building on it. ${ }^{{ }^{6}}$ Some struggles over land lead to violent incidents between villagers and buyers or between villagers and the chief. ${ }^{17}$ And there have even been reports of large-scale violent uprisings of villagers against the chief.

An example of such violence occurred in Pekyi $n^{\circ}$ 2, where the chief sold a big part of village land to the Deeper Life Christian Ministry and pocketed the money. The commoners chased both the chief and the church representatives out of the village, killing one of the latter in the action. Another well-known strategy is to install a Plot Allocation Committee (PAC), as was tried in Besease. One May afternoon, the gonggong was beaten in Besease to announce a village meeting. Two hours later the Beseasehene, the UC, and two dozen villagers had gathered on the crossroads in the middle of the village. One of the members of the UC addressed the meeting. He explained that they had called this meeting to install a PAC, that would from that moment on sign all land allocation papers and secure a certain percentage of the revenue for community development. He claimed that the chief had sold a lot of land in his two years reign and whereas "we use the money for development of the town, he uses it to buy a big cloth." When the chief responded by denying any land allocations, the villagers were incredulous and astonished. While the sun went down, more and more people kept flocking towards the meeting place, and the tension rose. After some time of uncoordinated discussion, the chairman of the UC intervened. The people silenced to hear his soft voice stating that approximately twenty plots had been sold in the last two years, but the chief had allowed the UC to sign the papers of only five of these plots. The chief was now openly irritated and again denied these facts, which elicited vehement reactions of the gathered crowd. Many villagers, men and women, young and old, were by now shouting outright and swearing at the chief. After some more time of heated debate, the chairman again calmed the people and announced that the chief had agreed to install a PAC. They proceeded to appoint the committee members. The chief selected two of his confidants, the UC brought forward two representatives, and the villagers appointed two leaders of the commoners. ${ }^{18}$

The example above shows that tempers can rise high when land is concerned and that the traditional respect of the people for the chief can suffer from his maladministration of land. According to the assemblyman of Esereso, "now that the chief does not supply the families with land 
they can speak disrespectfully of him in the village" (Interview, Io April 2003). Along the same lines, the Kontihene subchief of the Beseasehene states that because of the maladministration of land by the Beseasehene "no one recognizes him as the chief. No one goes to him for dispute settlement" (Interview, I July 2003). As said before, this poses the question to what extent and how chiefs' dealings with land affect people's views on the other tasks and activities of chiefs, as well as people's attitude towards chiefs and chieftaincy in general. This same issue has been raised in other countries. Claassens (2006: 26), analyzing local land administration in South Africa, states that "(s)elling land undermines the legitimacy and support base of traditional leaders among community members." And Fisiy (Fisiy I992) says of Cameroon: “The rampant alienation of land by sale, especially to strangers (Fulani graziers), is seen as egoistic and potentially ruinous to the institution." We will now consider this question for peri-urban Kumasi.

\section{Local development projects}

Some of the other tasks of chiefs mentioned in the survey are: looking after the physical development of the town (50\%), ensuring community participation in development (59.1\%), and organizing communal labor $(27.7 \%)$. We analyze these three tasks together under the heading of 'organizing local development projects.' When such projects are initiated in villages the chief is often involved in some way or other. He is often considered as the line to the civil authorities. He might also be asked to supply land for the project, to deploy his public function for fundraising activities at the local level, to mobilize his people for communal labor or education campaigns, and to function as a guest of honor at opening ceremonies. Because of his function as representative of the people, the chief is often regarded as the focal point for government, NGOs, developers, and investors. ${ }^{\text {I9 }}$

Besides chiefs, local government representatives are often also involved. This poses some questions with regard to the relationship between these actors. Two main themes in the literature on this issue are the co-optation of local government by traditional elites (see for instance Abudulai 2002; Moore I973) and the tensions between local government and traditional authorities (Ntsebeza 2003; Ntshona and Lahiff 2003; Vaughan 2003: I46, I70). Although it sometimes happens that local government representatives are allied to the chief - for instance in Nkoranza the assemblyman was also the Ankobeahene subchief and in Jachie he was the chief's maternal nephew - in peri-urban Kumasi local government is largely unconnected ${ }^{20}$ to the traditional elite and this elite does not seem to make much of an effort to change 
that. The lack of interest by the traditional elite in co-opting local government can be understood by the fact that the positions of UC and DA member do not offer much opportunity for personal gain. They receive hardly any remuneration and their jobs can be strenuous and frustrating because of high expectations and demands for development projects from the locality, with a lack of funds to meet these demands. This analysis is supported by the rapid turnover of representatives: most of them hold their positions for only one or two terms.

In peri-urban Kumasi the relationships between chiefs and local government representatives are highly varied, ranging from co-operation to high-rising tensions. In the villages where chiefs use a substantial part of the revenue from land conversions or from other sources for projects in the village, such as electrification, building of schools, libraries, KVIPs (Kumasi Ventilated Improved Pit Latrines), sanitation projects, local government representatives often take an active role in supporting such projects; they organize and oversee communal labor and help with local fundraising, etc. However, in other villages, where little of the local revenue is used for development purposes, tensions between chiefs and representatives of local government can rise high. The latter often play an important role in challenging maladministration by chiefs. According to the planning officer of Ejisu-Juaben DA, many conflicts in villages are between UCs and chiefs (Interview, 2 April 2003). The example of Tikrom, discussed above, is a case in point.

The involvement of chiefs in formal occasions such as opening ceremonies, and their speeches at such happenings, are often chronicled in local and national newspapers. Both Ray and Eizlini $(2004)^{2 \mathrm{I}}$ and Owusu-Sarpong (2003: 4I, 43) conclude from such newspaper reports that not only is there a vivid interest in Ghana in traditional matters, but also that local government representatives and traditional rulers work hand-in-hand for the benefit of the people. The latter, however, is a debatable conclusion, as the following case shows. In Besease, the UC and assembly members organized an Easter Convention to raise funds for building a library in the village. Every villager was obliged to pay a fixed amount, and many people originating in Besease but now residing elsewhere had also come and brought their donations. It was a true village festival, with most adults of the village present, the churches involved, a number of chiefs ${ }^{22}$ and subchiefs of Besease present, and the local member of parliament and the District Chief Executive invited as special guests. The Beseasehene, however, was absent, as was the Beseasehemaa (queenmother). They sent a letter to the assemblyman, which was read out loud at the convention, which explained their absence with reference to a dispute with the village over a piece of land. A few months later, the library was built, the book cases piled high with secondhand books, and flowers planted in front of the 
building. Time for an official opening. Again a big ceremony was organized, with students from the three local schools performing pedagogically sound plays, reciting sweet poems, and singing many-voiced songs. All Besease chiefs and subchiefs joined in full regalia, each with their Okyeame and their Kyiniyehene - their spokesman and umbrellabearer. The Beseasehene was also present this time and gave a speech, in which he, the chief of Besease, emphasized the importance of education and reading in general for his people. It is not difficult to imagine newspaper headlines such as: "Beseasehene stresses importance of education during opening of new library" or "Beseasehene advises parents to avoid engaging children in economic activities at the expense of their education." It is from similar rhetoric that Ray and Eizlini conclude that "chiefs are actively involved in supporting the education system in Ghana" (Ray and Eizlini 2004: I4). The Besease case, however, shows that a representational role for the chief in an opening ceremony does not necessarily mean an active involvement or financial input at any stage in the project. It does not even signify a cordial relationship between chief and local government representatives.

A disturbed relationship between chief and local government representatives can have various consequences. For instance in Tikrom, despite harsh confrontations between local government representatives and the chief, the UC has been unsuccessful in obtaining for community development any part of the money from land conversions. This has disillusioned UC members, who have also been unable to obtain revenue for development projects from other sources. Combined with the chief's unwillingness to co-operate with the UC, this has undermined the UC's functioning. As a result the UC hardly exists, with only a few of the initial members still active in the village. In Besease on the other hand, the lack of development by the chief has stimulated local government representatives to take the initiative in development projects, as in the case of the library, or in solving other local problems. A parent in the village explains: "Once I went to talk to the Beseasehene about one of the school buildings. But he said that he did not have any children at that school so it was not his problem." The parent then turned to the UC (Interview villager Besease, 26 August 2003). Oomen (2002: 200) shows that one of the reasons why people support traditional leadership is because of a lack of alternatives. This argument can also be turned around: where the chief no longer functions, many people turn to local government. According to a subchief, "If the chief has squandered money and refuses to account to the people, if he is rude or not paying what is due to the town, the UC will run the town" (Interview Kontihene of Ejisumanhene, Besease 27 May 2003). It should be mentioned, however, that two years after the successful library project, the UC members of Besease were so disillusioned that 
the Plot Allocation Committee had still not started functioning and the UC therefore was still not receiving any part of the revenue from land conversions in the town, that no new projects were initiated, and even communal labor was no longer carried out.

All this leads us to ask how the people in peri-urban Kumasi feel about these issues. Whom do they regard as the most appropriate actors for various tasks? Do they take an active interest in issues of local government? And how do they assess the performance of the various actors? Table 4 shows whom the surveyed people consider the most appropriate actors to perform certain tasks. For all five tasks in Table 4 the chief is only considered the third or fourth most appropriate actor. It is striking that for three of the main tasks of the chief mentioned in Table I - ensuring community participation (59.I\%), physical development of the town (50.0\%), and organization of communal labor $(27.7 \%)$ - both the UC and the local assembly member are considered more appropriate actors than the chief. "Communal labor in Besease used to be arranged by the chief," says the queenmother of Besease, "but because of the dissatisfaction with the chief's land administration, nowadays when the gonggong is beaten, they use the names of the UC and the assemblyman, not the chief" (Interview Besease, 29 May 2003). These data qualify Brempong's (200I: I09) statement that "in spite of local agencies ... traditional rulers are regarded and are expected to act as development agents." The current research shows that people do consider development a task of the chief, but at the same time do not regard him as the most appropriate actor for it.

Many villagers take an active interest in local government. $8 \mathrm{I} \%$ of the surveyed people said they had voted in the last elections for the DA and the UC (compared to $89.3 \%$ in the last national elections). 85.5\% of the surveyed people knew their assembly member and 94.2\% knew

Table 4 Which actor(s) should perform certain tasks?

\begin{tabular}{|c|c|c|c|c|c|}
\hline Tasks & UC & $\begin{array}{l}\text { Assembly } \\
\text { member }\end{array}$ & DA & Chief & $\begin{array}{l}\text { Central } \\
\text { govt }\end{array}$ \\
\hline $\begin{array}{l}\text { Ensuring community } \\
\text { participation }\end{array}$ & 59.1 (1) & $36.0(2)$ & $1.2(4)$ & 15.7 (3) & $0.4(5)$ \\
\hline $\begin{array}{l}\text { Physical development } \\
\text { of the town }\end{array}$ & $24.8(2)$ & $58.3(1)$ & $5.0(5)$ & $16.9(3)$ & $16.9(3)$ \\
\hline $\begin{array}{l}\text { Organization of } \\
\text { communal labor }\end{array}$ & $87.6(1)$ & $18.6(2)$ & $0.4(5)$ & $7.0(3)$ & $0.8(4)$ \\
\hline $\begin{array}{l}\text { Check concurrence with } \\
\text { building regulations and } \\
\text { planning schemes }\end{array}$ & 33.9 (1) & $25.2(3)$ & $31.4(2)$ & $7.0(4)$ & $1.7(5)$ \\
\hline $\begin{array}{l}\text { Promotion of economic } \\
\text { development }\end{array}$ & $27.3(2)$ & $43.0 \quad(1)$ & $12.4(4)$ & 20.7 (3) & $9.9(5) 0$ \\
\hline
\end{tabular}


at least some of the UC members. ${ }^{23} 90.5 \%$ of the people felt that they had a say in community affairs. In the survey, people were also asked to score the performance of their chief, assembly member and UC on a 5 -scale ( $\mathrm{I}=$ very bad, 5 = very good): see Table 5 .

The assembly members score significantly lower (2.85) than both the chiefs (3.52) and UCs (3.57). This reflects the difficulty of their jobs. Despite the lack of remuneration assembly members are expected to serve not only in their own village but in one or two other villages as well. In these villages people often complain that the assembly member never visits them, or even that they don't know him/her, and that these members only care about their own villages. In the four survey villages $(\mathrm{N}=\mathrm{I} 2 \mathrm{O})$ where the assembly member lived in the village, $98.35 \%$ of the people knew their assembly member, compared to $72.93 \%$ in the four villages where the assembly member did not live ( $\mathrm{N=I22)}$. In the first set of villages the performance of the assembly members is assessed with an average of 3.37, whereas in the latter villages they score only 2.27. Furthermore the assembly members are mainly judged on their success in obtaining development projects from the DA, which itself is low on funds. The higher score of UCs might imply that the UCs have lost the bad image resulting from their history as revolutionary councils. ${ }^{24}$

The average score for chiefs is 3.52 , which signifies something in between average and good. In three villages the chiefs score under average, in four villages above. There is a strong correlation between their score and their 'style' of land management and its effects in the locality. In Ahenema Kokoben (2.59) and Tikrom (2.62) the chief has sold much land, with little revenue for the community. In Adadeentem (2.97) the former chief sold a large tract of land very much against the wishes of the people, which sharply contrasts with the new chief who has not sold any land yet, but has already started building a primary

Table 5 Performance Assessments: Chief, UC and DA member

\begin{tabular}{llll}
\hline Village & Chief & UC & DA member \\
\hline Jachie & 4.72 & $4.07 * * *$ & $3.65 * * *$ \\
Nkoranza & 4.17 & $3.54 \%$ & 3.93 \\
Kotwi & 4.04 & 3.58 & $3.09 *$ \\
Brofoyeduru & 3.54 & $4.12 *$ & $1.96 * * *$ \\
Adadeentem & 2.97 & $4.00 * *$ & 2.15 \\
Tikrom & 2.62 & 2.92 & $2.00 *$ \\
Ahenema Kokoben & 2.59 & 2.83 & 2.50 \\
Boankra & No chief & 3.56 & 3.50 \\
All villages & 3.52 & 3.57 & $2.85 *$
\end{tabular}

* Difference with assessment performance chief is significant at the 0.05 level.

** Difference with assessment performance chief is significant at the 0.01 level.

$* * *$ Difference with assessment performance chief is significant at the 0.001 level. 
school from his own money. ${ }^{25}$ In Brofoyeduru (3.54) it is mainly the people who are profiting from the land conversions by selling their own land, a process which is being condoned by the chief. In Kotwi (4.04) many farmers had already sold their land to commercial farmers in the last decade. The current conversion of these lands therefore does not take away local people's livelihoods. Nkoranza (4.I7) still has more than sufficient agricultural land, as a result of which the people hardly feel the effect of land sales by the chief. The Jachiehene (4.72) has converted much farmland into residential land, but he shared both the land and the profits with the community.

Despite this strong correlation, when asked about their overall performance chiefs do not receive very bad assessments, even when in interviews people expressed outright criticism of the way they managed the land. It has been suggested that the traditional respect for chieftaincy makes it difficult to grade chiefs with an unsatisfactory mark. This argument seems to be brought down, however, by the fact that during interviews and participant observations severe criticism of the chiefs was freely and frequently voiced. Should the relatively favorable assessment of chiefs then be attributed to their performance in other fields? We have now discussed four of the main tasks of the chief mentioned in Table I. With regard to land administration, many villagers do not consider the chiefs to play a very positive role. With regard to physical development of the town, organizing communal labor, and ensuring community participation, we have seen that for these tasks, local government is now preferred over chiefly rule. The next sections will therefore discuss the last three tasks mentioned: dispute settlement, ensuring peace in the community, and celebrating traditional festivals.

\section{Law and order: dispute settlement and ensuring peace}

"Dispute settlement" ranks first as main task of the chief (78.1\%), and is closely connected to the third ranking "ensuring peace in the community" (53\%) (Table I). ${ }^{26}$ When asked the hypothetical question, whether they would go to the chief if they had a land problem, $76.4 \%$ of the surveyed people answered in the affirmative. In-depth interviews, however, showed that in cases where the chief is one of the parties to the conflict - as is often the case when farmland is converted to residential land - people do not consider the chief's court an acceptable forum for settlement of the dispute.

Of the people surveyed 10.4\% had at some date taken a dispute to the chief: ${ }^{27} 25.6 \%$ had been witnesses in such a case. These figures are difficult to read without knowledge of how many people were involved 
in disputes, and how many went to other dispute settlers. Crook et al. seem to be the only researchers providing empirical data on such questions regarding the use of various dispute settlement systems in Ghana (Crook et al. 2005). In a survey, they asked 677 people who they would most trust to settle any problem they might have concerning their land. The people most frequently mentioned as 'trusted a lot' were, firstly, village chiefs (62.1\%), second family heads (6I.4\%) and third court judges $(35.4 \%)$, with UC chairmen coming a close fourth (34.2\%). In peri-urban Kumasi, the UC chairmen ranked third (37.8\%), paramount chiefs fourth $(28.4 \%)$ and court judges fifth $(20.9 \%)$. The general trust rankings showed very little difference in levels of trust between men and women, between various age groups, or between people with different levels of education. Only the origin of respondents produced some interesting differences: migrants from a different district or region showed much less propensity to trust a paramount chief and were more likely to trust a judge (Crook et al. 2005: 73-77). ${ }^{28}$

A widely shared belief is put into words by Boafo-Arthur when he states that "there are many instances, at the rural level, where societal conflicts are referred, first and foremost, to the traditional ruler for arbitration. In most cases, it is where the parties are not satisfied by the judgment of the traditional arbitration system that the case is taken to court" (Boafo-Arthur 200I: I0; cf. Schott I980: I25-6). Crook et al., however, come to a different conclusion. They show that, out of I53 respondents that said they had personally experienced a land dispute, only $26.1 \%$ had turned in the first instance to the chief, while $73.9 \%$ had initially taken other roads to settle the issue: they turned to their family or to the court, used arbitration by respected persons, or had the issue sorted out through negotiation with the other party (Crook et al. 2005: 72). ${ }^{29}$ A division of respondents according to origin demonstrated that non-locals were only half as likely as locals to have used a chief's court (I6.3\% and 31.1\% respectively: Crook et al. 2005: 78). Additionally, they demonstrate that out of I68 land case litigants in Kumasi High Court, $52.2 \%$ went straight to court, without first employing any other dispute settlement mechanism (Crook et al. 2005: 30; cf. Crook 2005).

It is clear from the data from Crook et al. and from the current research that chiefs remain an important source of dispute settlement at the local level and enjoy high levels of trust in that area, albeit more among locals than among migrants. They may or may not get satisfaction for their problem at the chief's court, but at least villagers usually get easier, cheaper, and faster access to their chief than to state courts. The position of Ashanti chiefs in dispute settlement has even been somewhat enhanced by - and the role of state courts has equally suffered from - an appeal by the Asantehene at his inaugural meeting 
with the Kumasi Traditional Council in I999 to the chiefs to withdraw cases pending in the state courts and in the Houses of Chiefs and bring them to his court for settlement. Since this appeal - which was followed by quite a number of people, although numerous cases were also not withdrawn from state courts - over 500 land, chieftaincy, criminal and civil cases have been settled in the Asantehene's traditional court (Boafo-Arthur 2003: I47; Otumfuo Osei Tutu II 2004). ${ }^{30}$ Crook et al., however, also demonstrate an ambiguity. Whereas village chiefs are still cited by the general population as most trusted persons for resolving a dispute, actual personal experiences of dealings with a dispute showed a rather more varied picture. Chiefs accounted for only a minority of dispute settlement institutions resorted to, others being family heads, respected persons, and opinion leaders including elected local government representatives (Crook et al. 2005: 89). Furthermore, Crook et al. confirm the finding from our qualitative research that the continuing conflict in peri-urban areas over the role which chiefs play in the appropriation of village lands for sale as urban plots, is an important difficulty surrounding the chiefs' role. In such circumstances, Crook et al. conclude, the chief may be regarded as having too much personal interest to be trusted as an impartial judge of a local land case (Crook et al. 2005: 74-5).

\section{Traditional religion}

In the literature, the person and function of the chief are very much connected to traditional religion (Busia I95I; Hagan 2003; Rattray I969, first published I929; Ray 2003b). Busia wrote in I95I that ancestor-worship was the basis of the chief's authority as well as the sanction for morality in the community. The belief that the ancestors were the custodians of the laws and customs and that they punished those who infringed them with sickness or misfortune acted as a check on commoners and chiefs alike (Busia I951: 24, I36; Fortes I962: 78. Cf. Nukunya I992: I28). According to Ray,

"the basis of the respect accorded to the chief is not only that the chief derives his power from the people, but also that the stools, skins and other symbols of office have a spiritual significance the chief deriving his power from the ancestors and mediating between the people and the ancestors". (Ray 2003b: 7)

In Daneel's analysis it is due to the religious base of chiefly authority that chiefs are able to mobilize people to protect the environment (Daneel i996: 348). 
Of the people surveyed only $0.8 \%$ claimed traditional religion as their faith, with $45.6 \%$ orthodox Christians, $37.8 \%$ charismatic Christians, and 6.6\% Muslims (see Table 6). Despite the variety of 'new' religions, some researchers claim that the chief's role is "well-defined and is embedded in local cosmological views, norms and values which are respected by everyone in the particular society" (emphasis added, Ray and Van Rouveroy van Nieuwaal I996: 25). Others assume that in a society in which political and religious office are combined in the chief, new religions are regarded as a challenge to traditional leadership. These researchers look more critically at the effects of changing religions and worldviews on chiefly rule. Asiama for instance thinks that:

"the effect of education and European acculturation, coupled with the departure of a majority of the people from the traditional African religion built on ancestral worship, have made people believe less in the divinity of the chiefs and the strength of their connections with the departed ancestors." (Asiama 2003: I3)

According to Hagan divergent faiths and world views not consonant with traditional beliefs will lead either to the secularization of the institution or to the narrowing of faith allegiance to the stool (Hagan 2003: 7). Historical evidence shows that in many places and for many years people have been using conversion to free themselves of service to their chiefs, justifying their behavior by claiming that they do not want to take part in "fetish observances" (Brempong 200I: 58; Busia I95I: I34; Hagan 2003: 7).

Only $8.3 \%$ of the people surveyed mentioned the celebration of traditional festivals such as Akwasidae as a main task of the chief (Table r). Some Christian charismatic churches agitate against such traditional religious practices. The pastor of the 'Assemblies of God' in Besease explains his church's stance towards chieftaincy and traditional religion thus:

Table 6 Religion of interviewees

\begin{tabular}{lc}
\hline Religion & $\%$ \\
\hline Christian, orthodox & 45.6 \\
Christian, charismatic & 37.8 \\
Muslim & 6.6 \\
Traditional religion & 0.8 \\
Other religion & 0.4 \\
No religion & 8.7 \\
\hline
\end{tabular}


"We teach that pouring libation and praying to dead people is against the law of God. We preach against it in church. Chiefs and heads of families (abusua panin) who are born again refuse to pour libation. They let one of their elders do it for them. That is accepted by the church. The church does not agree with the celebration of Akwasidae. But we can't say they should abolish it, everyone has its freedom of worship. We just don't want anything to do with that, but we don't fight against it. We teach our members not to get involved. But some of the members are not properly committed, these might still pour libation. Chieftaincy is still important for the people. Even in the bible there are kings. They are very important to the nation, if there is no chief, people will behave unruly. If there is a chief, people will fear for punishment. We therefore do not preach against chieftaincy as a function. Although the chief has a role to play in dispute settlement, we teach the people not to go to non-Christians. We will settle all issues in the church amicably. In that sense, the church takes over part of the role of the chief." (Interview, I2 September $2003)^{31}$

The orthodox churches, on the other hand, see no harm in traditional practices such as pouring libation and celebrating Akwasidae. Many Christians condone or partake in them..$^{32}$ According to one elder, "Almost anybody will pour libation, to remember the ancestors. To know they are remembered, you mention their names" (Interview elder of the Kontihene of Ejisumanhene, Besease, 7 May 2003). Some people, however, refuse to actively partake in traditional religious practices. A chief recollects: "when my father and mother opted to be catholics, they cherished the church so much that anything relating to custom was taboo for them" (Interview Kontihene of Ejisumanhene, Besease, 27 May 2003) This has also led certain people to decline an offer to become chief, because of the inherent necessity to pour libation and 'feed the stools' (Personal communication, researcher Institute for Land Management and Development, Kumasi, I5 April 2003). Some years back, a chief declared in a radio interview that he no longer believed in the sacred rituals of the stool room. He refused to pour libation to the ancestors, which he considered to be demonic. Because of these statements, the chief was destooled before the Asantehene, the late Opoku Ware II (Hagan 2003: 7). Celebration of the traditional festival of Akwasidae has changed a lot over the last decades. "Akwasidae used to be celebrated by the whole town in the open, first in Ejisu and then in Besease," a Besease chief narrates. "Libation would be poured, a sheep or goat killed, and no one would go to the farm that day. Now it is a closed ceremony, with only the chief and the linguist present. This year 
one Akwasidae was not celebrated because it fell on Easter Sunday" (Interview Kontihene of Ejisumanhene, Besease, 27 May 2003). The fetish priest used to dance and drum on festive days. But since the priest died, they have been unable to find a new one. "Christianity has made the shrine so low," explained one of the villagers (Personal communication villager Besease, I2 May 2003). At the same time, when asked whether they would mind if the celebration of the traditional festival of Akwasidae were to be cancelled 54.5 percent of the people - and $60.6 \%$ of the people that originated from the survey villages - said yes. ${ }^{33}$ Two villagers' views on traditional religion are worth quoting: "People think that pouring libation is praying, but they don't pray to the real God," says a female charismatic Christian from Besease. "They call on God with alcohol, but the real God does not like alcohol. These are evil spirits." With regard to Akwasidae she says: "If it were a public ceremony I would not go because it is not the calling of the supreme God. It is fetish. But it should not be cancelled. We met our parents and grandparents doing that" (Interview villager Besease, 27 August 2003). A woman from a different charismatic church in Besease says: "Everyone goes to church, so only the chief and the houses who have stools pour libation. I go to the Baptist church, my mother to the Bethany church. These churches preach against such practices. But Akwasidae should not be taken out. It is custom (amanne). It should be there for the ones who want it." (Interview villager Besease, 26 August 2003)

These data again do not present an unambiguous picture. Only $0.8 \%$ of the surveyed people claimed traditional religion as their faith. We may conclude, in line with Hagan (2003: 7), that this trend most likely leads to the narrowing of faith allegiance to the stool. It might also have its effect on other functions of the chief, such as dispute settlement. It cannot be interpreted, however, as a rejection of all aspects of traditional religion. Many Christians and Muslims still condone or adhere to facets of traditional religion and ancestor worship. And while only a small minority $(8.3 \%)$ of the people mention the celebration of traditional festivals as a main task of the chief, a majority attaches importance to their continuation.

\section{Perceptions of chiefs and chieftaincy}

In this chapter, we have discussed chiefly rule and popular perceptions in four fields, structured around the seven main functions of the chief as listed by the people (Table I). We started with a description of dealings with land in peri-urban Kumasi and saw that many people are highly critical with regard to this aspect of chiefly rule. We furthermore 
saw that in the field of local development projects the chief was regarded as only the third or fourth most appropriate actor, behind the UC and the local assembly member. The field of law and order showed a stronger but ambiguous role for chiefs. Whereas village chiefs are considered the most trusted persons for resolving a dispute, chiefs accounted for only a minority of dispute settlement institutions resorted to, and the continuing conflict over the role which chiefs play in the appropriation of village lands for sale as urban plots sometimes affects their ability to judge local land cases. With regard to the field of traditional religion the data showed that most people surveyed were Christians and Muslims. Although this most likely leads to the narrowing of faith allegiance to the stool, we saw that it does not imply a total rejection of all aspects of traditional religion or the role of chiefs in its performance.

The survey data showed that the assessment of village chiefs is correlated to their 'style' of land management. But despite very negative judgments on chiefly performance in that area, chiefs' overall performance assessments are not overly negative; they range from a bit under average to good. ${ }^{34}$ We have posed the question whether this could be attributed to the performance of chiefs in other fields. If that were so, however, variation in chiefly performance in these other fields would influence their assessment, which does not square with the clear correlation between style of land management and performance assessment that we found for peri-urban Kumasi. For an answer to this question of relative positive assessments of chiefly functioning we should therefore look in another direction, for which we need to make a distinction between the person of the chief and the institution of chieftaincy.

In Table 7 the assessment of village chiefs is compared to the assessment of the Asantehene and of the institution of chieftaincy. These data display firstly that the assessment of chieftaincy shows a low correlation ${ }^{35}$ to the assessment of the village chief and, secondly, that the

Table 7 Performance assessments village chief, Asantehene and chieftaincy

\begin{tabular}{lccc}
\hline Village & Chief & Asantehene & Chieftaincy \\
\hline Jachie & 4.72 & 4.81 & 3.72 \\
Nkoranza & 4.17 & 4.82 & 3.33 \\
Kotwi & 4.04 & 4.93 & 3.80 \\
Brofoyeduru & 3.54 & 4.88 & 3.45 \\
Adadeentem & 2.97 & 4.93 & 3.57 \\
Tikrom & 2.62 & 4.66 & 3.30 \\
Ahenema Kokoben & 2.59 & 4.69 & 3.22 \\
Boankra & No chief & 4.93 & 3.56 \\
All villages & 3.52 & 4.81 & 3.49 \\
\hline
\end{tabular}


assessment of chieftaincy does not differ significantly per village. This clearly shows that people's opinions about chieftaincy hardly depend on the performance of current village chiefs or, to put it differently, that the way a chief governs barely reflects on the institution. A distinction between the institution of chieftaincy and its incumbent has also been described in political oratory among the Barolong boo Ratshidi on the South Africa-Botswana borderland (Comaroff I975) $^{3^{6}}$ and for Sesotho culture in South Africa (Oomen 2002: 205). Unlike the data presented here, Oomen's information led to the conclusion that this 'delinking' of chieftaincy from individual chiefs in local political debate did not take place in people's assessments of chiefs and chieftaincy. Quite the reverse, she shows a clear causal relationship between the way people feel about their chief and their opinions on chieftaincy. As said earlier, in peri-urban Kumasi this causal relationship is missing: the way people feel about their chief seems not to influence their opinion on the institution of chieftaincy. Perhaps we could even turn the argument around and suggest that respect for the institution of chieftaincy carries weight in and contributes to the assessment of individual chiefs, which could explain the fact that individual chiefs are assessed rather better than was to be expected on the basis of their land practices.

This dissimilarity between the Ashantis and the Sotho matches with the fact that the institution of chieftaincy is highly debated in contemporary South Africa, whereas it is almost a fact of nature in Ashanti. In peri-urban Kumasi dissatisfaction with local land administration and anger towards a particular chief hardly seem to lead to discussions of the desirability of the institution of chieftaincy. For the majority, chieftaincy is a fact. According to a youngster: "The youth don't respect the chief as they used to. When they have a dispute they would sooner go to the police or to court than to the chief. But chieftaincy has to be there. It is not old fashioned." (Interview youngster Besease, I5 June 2003) It is almost unthinkable for a village not to have a chief. Without a chief there is no village, for who will represent the community at traditional and cultural festivals and ceremonies? "Chieftaincy is the culture of the people," explains the District Chief Executive. "They feel an emptiness if there is no chief. They think leadership is lacking, authority is no longer there. Especially on festive occasions, people want to belong to a chief." (Interview District Chief Executive, Ejisu, 9 September 2003)

Table 7 also shows a significant difference between the assessment of the village chiefs and of the Asantehene. ${ }^{37}$ The assessment of the Asantehene is strikingly high in all villages. This is understandable, since it is felt that the prestige of the Asantehene reflects on the status of Asante and the Ashantis. This has its bearing on the same issue of representation. For you need a village chief to communicate with high- 
er chiefs and with the Asantehene, who is highly revered and whose position is unquestionable.

Respect for the institution of chieftaincy, however, should not be confused with respect for the person on the stool. As we have seen from the villagers in Besease swearing and shouting at the chief during the village meeting to install a Plot Allocation Committee, the latter does not always prevail. In general, it was quite common during the fieldwork to hear villagers talk in derogatory terms of their chiefs.

\section{Conclusions}

In the introduction, we demonstrated that in the literature the resurgence of chieftaincy is often explained by either pointing to how international trends of multi-party democracy, decentralization, liberalization policies, and structural adjustment have opened up new public spaces for traditional leaders, on which they have aptly and skillfully capitalized, or by pointing to the functions performed - successfully in the authors' opinion - by chiefs. Both explanations pay hardly any attention to how people feel about chiefs, the way they rule and the institution of chieftaincy. Chieftaincy literature in general hardly provides any data on people's perceptions. This is reflected in the fact that national and international policies on chieftaincy often do not seem to take into account people's perceptions. The cases in peri-urban Kumasi show that the support for chieftaincy is not based on high satisfaction with the way chiefs perform their tasks. Reasons are rather found in the realms of culture and identity, as the quotes above make clear (cf. Oomen 2002: 223). ${ }^{38}$ This is an important lesson for African governments and international policy makers, since it demonstrates that people's support for the institution of chieftaincy does not necessarily go hand in hand with satisfaction regarding chiefly performance. People can simultaneously support the institution of chieftaincy and be highly critical of the performance of certain chiefs or certain tasks. Whereas governments' moves towards more formal recognition of chieftaincy are sensible in countries where chieftaincy is regarded as a naturalness by most people, this should not lead to uncritical acceptance of the way chiefs perform all their functions. Policy makers should critically assess chiefly rule - and popular perceptions of it - in various fields, taking into account the performance of other actors in these fields, including local government representatives. Based on such assessments, governments should determine the desirability to recognize, formalize, or enhance, in a ceremonial or more material form, the various functions of the chiefs. And if necessary they should place checks and balances 


\section{on the functioning of chiefs in general and regulate or control certain fields in particular.}

\section{Notes}

I Field work in Ghana on which this research is based was supported by the Netherlands Organization for Scientific Research (NWO/WOTRO), the Leiden University Fund (LUF), Mordenate College, and the Adatrechtstichting.

2 The customary community is called a 'stool' in reference to the carved wooden stool which is believed to contain the souls of the ancestors and is a traditional symbol of chieftainship.

3 Exceptions cover Botswana, Malawi and Nigeria (Englebert 2002: 5I; Kyed and Buur 2005: I). Despite these attempts, in many countries chieftaincy survived, although sometimes merely as a folklorized apology (Englebert 2002: 58; Van Binsbergen I996; Van Rouveroy van Nieuwaal i996: 43; Von Trotha 1996: 87).

4 The socialist Frelimo government banned chiefs at independence in 1975 and set up new governance structures. Despite this, the chiefs continued to play an important role in the rural areas both during and after the war. In response, the government in 2000 decreed the chiefs a role as state assistants and community representatives. In 2002 a little over one thousand chiefs were formally recognized as rural 'community authorities' and delegated an extensive list of state administrative tasks and civic-educative functions (Buur and Kyed 2005; University of Sussex : MZor; Kyed and Buur 2005).

5 The powerful kingdom of Buganda, abolished in Uganda's I967 Constitution after the Buganda king had been exiled in 1966, was restored to a certain extent in I993 by President Museveni. In I995 the Constitution was redrawn to recognize the institution of traditional leaders (Englebert 2002: 53; Herbst 2000: I77; Ray 2003b: II).

6 Claassens (2006), Ntsebeza (2003), Ntshona and Lahiff (2003) and Oomen (Oomen I999: 73; 2002) describe a surprising continuation and even strengthening of traditional leaders' formal position in post-apartheid South Africa.

7 See for instance the fourth African Development Forum 2004, Addis Ababa, where the Asantehene - the highest traditional leader or king of Ashanti, Ghana - was invited for the keynote address (Otumfuo Osei Tutu II 2004); the conference on 'Leadership dialogue with traditional authorities', Kumasi, where a speech was held by the senior vice president of the World Bank (Dañino 2005); the Commonwealth Local Government Forum on 'Traditional leadership and local government', Gaberone (Ray, Sharma, and MayParker 1997); and the conference on 'African traditional leaders. Partners in the development of Africa and the realization of the African Union', Kumasi, 2003.

8 This can for instance be witnessed in South Africa (Ntsebeza 2003; Ntshona and Lahiff 2003; Oomen 2002) and Ghana (Crook 2005; Ministry of Lands and Forestry 2003).

9 Chiefs and government elite should not be regarded as clearly separate and discernible entities. In many African countries, the distinction between traditional and state elite is fading. Both because chiefs are now often highly educated and involved in business activities, and because chiefs have in most countries become to a certain extent integrated in state bureaucracy (Bierschenk I993: 220; Ubink 2008, forthcoming; Van Rouveroy van Nieuwaal I996: 46, 60). To explain why certain states have witnessed a resurgence of traditional authorities while other states have not Englebert adds the following factors: I) the cultural profile of the resurgent groups; 2) the colonial culture of the state; 3) the strength of states - in the sense that strong states that are more confident in their own institutions and stability might be more likely than weak states to tolerate the rise of alternative sources of authority, at least in the cultural sphere or in areas of local land 
management and dispute settlement; 4) the failure of nation-building rather than statebuilding (Englebert 2002: 57-8).

Io The research combined qualitative research methods such as semi-structured interviews and participant observation with a survey among 242 villagers. To protect the identity of local informants, names of interviewees are not given. They are identified as villager, Unit Committee member, elder etc.

II The peri-urban area is most appropriately thought of as approximating a continuum from rural to urban. It is characterized by strong urban influences, easy access to markets, services and other inputs, ready supplies of labor but relative shortages of land and risks from pollution and urban growth (Edusah and Simon 200I; Simon et al. 200I). Five villages were situated on or near the road from Kumasi to Accra - Jachie, Tikrom, Besease, Adadeentem, and Boankra - and four villages on the road to Obuasi - Ahenema Kokoben, Kotwi, Brofoyeduru, and Nkoransa. All villages lie within a range of ten to forty kilometres from Kumasi.

I2 This accords with Crook et al. (2005: 89) who claim that chieftaincy in Ghana is much stronger than in Cote d'Ivoire.

I3 Through general elections $70 \%$ of the members of the DA are chosen on a non-partisan basis, but the District Chief Executive - the single most powerful local government position that dominates district level government - and the other 30\% of the DA members are appointed by the President in consultation with traditional authorities and other interest groups. It is claimed that the DAs lack sufficient authority and fiscal resources to initiate and implement policies and programs. Most DAs continue to rely on the national government for revenue and have not developed any significant local sources of revenue (USAID 2003: 3I). Chiefs in Ghana are not allowed to take part in active party politics or election to parliament (article 276, 1992 Constitution), but they do have representatives at a number of local and national government bodies, such as the Council of State, Regional Coordinating Councils and certain local government agencies.

I4 See for an elaborate description of struggles for land in peri-urban Kumasi Ubink 2008, forthcoming.

I5 As ohene is the Twi word for king or chief, the chief of Jachie is called Jachiehene.

I6 Because of lack of success in negotiations with the chief, many people do not aim their anger at the selling chief, but at the buyer. Both my fieldwork and a study of pending cases at the High Court of Kumasi show that the farmer - angry that his land has been sold by the chief - often tries to restrain the buyer from entering and building on the land. For instance in Adadeentem, the former chief has sold substantial parts of the land of the community. This brought a lot of dissatisfaction amongst the people, but no concrete actions were taken against the chief. One of the villagers, however, sued the buyer of a vast tract of land in the High Court of Kumasi. Another example of the 'buyer loses out' principle is found in Besease, where the Beseasehene sold two plots of the land belonging to his subchief, the Kontihene. On discovery of the sale, the Kontihene first "caused trouble with the Beseasehene", but "we enstooled him, so (...) we don't want to quarrel with him. But the buyer can't come and work on it. If you come to work you will meet the Konti”' (Interview Kontihene subchief of Beseasehene and one of the Konti elders, 20 May and I July 2003).

I7 For instance, the Beseasehene sold land that did not belong to his family (or to the family of his Kontihene subchief, as in the footnote above). When the buyer started to develop the land, the land-owning family restrained him. After the buyer applied to the chief to recover his losses, the chief "went to the land-owing family to plead, but he nearly got beaten up" (Interview elder of Kontihene subchief of Beseasehene, 20 May 2003).

I8 The other three land-owning chiefs of Besease were not present at this meeting, because at a previous meeting a fight had nearly broken out between them and the Beseasehene, 
who is trying to gain control over the land of the other chiefs. Another explanation for the tense relationship between these chiefs lies in the fact that the paramount chief of the area, the Ejisumanhene, has destooled (removed from office) the three chiefs, who have not accepted that and have brought a case against the Ejisumanhene to the Asantehene.

I9 Many localities are additionally installing so-called 'development chiefs' (Nkosuohene) outsiders that are honored with a traditional title after they have brought, or with the expectation that they will in future bring, development funds to the area (cf. Brempong 200I: 59).

20 One factor explaining why local government and traditional elite are largely unconnected is that the UCs find their origin in revolutionary people's committees (first called the Workers' and People's Defense Committees, later replaced by the Committees for the Defense of the Revolution), that were set up to 'tame the rapacity and irresponsibility of successive political, military and bureaucratic elites', including traditional elites (Crook I991: 98).

2I This paper forms part of a study on "Re-inventing African chieftaincy in the age of HIV/AIDS, gender and development: Volume I Overview" which has not been published yet.

22 Besease houses four subchiefs of the paramount chief in Ejisu. These chiefs all originate from Besease and take part in village meetings in Besease. Only one of these chiefs is the Beseasehene, the chief of Besease, dealing with all general matters of the village.

23 Throughout the villages $52.5 \%$ of the people said they knew all members of the UC in their village; $2 \mathrm{I} .5 \%$ said they knew many of them; $20.2 \%$ said they knew some of them; $5.4 \%$ said they knew none (0.4\% invalid).

24 This does not correspond with Crook et al.'s opinion that the Unit Committees have failed (Crook et al. 2005: 5).

25 Although the people of Adadeentem have elected this chief, the Ejisumanhene, the paramount chief of the area, is unwilling to enstool him. The Ejisumanhene preferred another chief-elect with whom he had been cooperating to alienate village land, for their mutual financial benefit.

26 Chiefs' courts are not accorded judicial functions by the state, and they are regarded as mere dispute settlement institutions. Chiefs are also not incorporated into state courts. These courts, however, do frequently apply customary law, which is one of the sources of law in Ghana.

27 Of the 25 disputes, I3 (52\%) concerned land.

28 In my own survey, the origin of respondents did not produce significant differences on the issues represented in this chapter.

29 Unfortunately, Crook et al. do not combine the data on first instance dispute settlers with data on the kind of disputes at stake, nor do they provide data on later instances of dispute settlement.

30 Although this was an understandable and sensible appeal considering the enormous backlogs in state courts, the move was also a highly political one in which the Asantehene reclaimed the traditional trias politica of legislator, administrator and judge.

3I Crook et al.'s research shows that for land disputes, church leaders only rank I6th (3.4\%) on the list of most trusted dispute settlers (Crook et al. 2005: 73).

32 Religion being such an important sphere of life in the villages, some of the religious leaders take an active role in the personal affairs of their followers. This was mainly confined to counseling and dispute settling in the field of family matters and witchcraft. I did not encounter in the case study villages instances in which they took an active role in opposing the chief when his rule brought hardship to the people. Even in Besease, where the assembly member was also a minister in one of the twenty-three local 
churches, this merely resulted in regular get-togethers of all religious leaders to pray for the welfare of the village.

33 In answer to this question $57.3 \%$ of the charismatic Christians said yes, $51.6 \%$ of the orthodox Christians, 3I.3 of the Muslims and 66.7\% of people with 'no religion'.

34 In another survey in peri-urban Kumasi in which the extent of villagers' satisfaction with their chief was measured, $28 \%$ of the people reported to be very satisfied; $50 \%$ satisfied; $4 \%$ not satisfied; I0\% absolutely not satisfied; and $8 \%$ did not know or did not answer (Hueber and de Veer i993a: 43).

35 The correlation is 0.357 , significant at the 0.01 level.

36 Comaroff describes that the people use a formal code to praise the qualities of the institution of chieftaincy in contrast with an evaluative code - which can be highly critical when they speak about a particular chief.

37 Significant at the $0.00 \mathrm{r}$ level

38 Oomen in her research (at 219-222) also points to the role of chiefs as 'portals of the government' and to the lack of alternatives for chiefly rule, but both these reasons were hardly mentioned in peri-urban Kumasi. 
Courts and Peri-Urban Practice: Customary Land Law in Ghana

Based on University of Ghana Law Journal (2002-4) 22: 25-77 Janine M. Ubink 



\section{Courts and peri-urban practice: customary land law in Ghana}

\section{Introduction}

Like most urban centers in Ghana, Kumasi has flourished in the last decades. Kumasi is the capital of the Ashanti Region, and houses the still vibrant royal court of the Asantehene, ${ }^{\mathrm{I}}$ the king of all Asantes. It is a bustling city and an important transportation hub. Its number of inhabitants has grown by $4.2 \%$ annually since I960, to I, 400,000 at present, due to both population growth and extensive urbanization. This has led to an increased pressure on land in the peri-urban area. Increasingly farmland is being converted into mainly residential land, but also commercial and industrial land, especially alongside the major roads to Kumasi, where access to the city is easy and electricity available. Many peripheral villages have now become fully encapsulated by Kumasi.

Most of the peri-urban land is 'stool land' - the word 'stool' denotes the customary community, in reference to the carved wooden stool which is believed to contain the souls of the ancestors and is a traditional symbol of chieftaincy. This land is regulated by customary law. According to representations of customary law in textbooks and case law, the ultimate or allodial title to every portion of stool land is held in common by the members of a community (Asante 1969: 105-6; Danquah I928: 197-200, 206, 221; Ollennu I962: 29, 55-6; Ollennu 1967: 252-5; Pogucki I962: 180; Sarbah I968: 64-7; Woodman 1996: 53, 66, I07). ${ }^{2}$ The chief of that community is the custodian of the land and he is customarily and constitutionally obliged to administer the land in the interest and development of the whole community (articles 36 (8) and 267 (I) of the 1992 Constitution). The lands thus are communal properties. As long as there is vacant land each community member has an inherent right to use part of it for farming or building. This will give the member a usufructuary title to the land, which is heritable and is extinguished only through forfeiture, ${ }^{3}$ abandonment, or with consent and concurrence of the farmer. The usufructuary cannot be deprived of any of the rights constituting the interest. Not even the chief can lay adverse claim. After the death of a community member, the 
usufructuary interest usually devolves to the member's family and becomes family property.

In short, the allodial title of stool land lies with the community, the usufructuary interest with an individual or family, and the role of custodian is allocated to the chief. This multi-layered customary set-up allows considerable space for struggles and negotiations over who has the right to convert stool land from farmland to residential land and lease it out to a stranger, and also what should be done with the revenue generated in this process. Taking into account the fact that this conversion has severe effects on the livelihoods of peri-urban farmers, ${ }^{4}$ and that plots of residential land in peri-urban Kumasi easily fetch a price of $€ 2000$, it is hardly surprising that these struggles encompass a whole range of actors and are often severe and protracted..$^{5}$

In many villages, the first and major actor in the conversion process is the chief. In peri-urban practice the chiefs are often also the main beneficiaries. Although local farmers and families attempt to influence these processes in various ways in the local arena, they often achieve limited effect. Realizing the low effectiveness of many local acts of resistance, it is worth examining to what extent state courts serve as an alternative channel for restraining chiefs. This depends on the one hand on people's access to and the functioning of state courts, and on the other hand on the decisions reached by these courts and their execution at the local level.

This chapter will demonstrate that the Ghanaian courts in individual land cases protect the usufructuary interests of community members in stool land. Land practices in peri-urban Kumasi are, however, not in conformity with the rules of customary law as laid out in the courts. This difference can be explained by two factors, a legal and a political one. The legal factor consists firstly of the difficulty for a judge to define the applicable customary norm while there are in each locality variations within and conflicts about the contents of customary law. Secondly, a judge needs to translate these norms of 'local customary law' 6 for use in state courts, creating a 'judicial customary law' (Cf. Allott I975: 89 and Allott I977: II; Asante 1969: I00; Chanock I989; Koesnoe 1985: 105-7; Von Benda-Beckmann I985b: 77-95; Woodman I977: II5; Woodman I996: 46). The political factor refers to the limited effect of judicial decisions on peri-urban practice due to the political configuration at local and national levels, which is characterized by four features: the prominence of chiefs and customary law in stool land administration; the erosion of customary checks and balances; the very limited shadow of state law in the localities; and the government's attitude and actions with regard to chiefs and chieftaincy affairs.

This chapter starts in section two with a description of struggles for land in peri-urban Kumasi, the discourse and actions by chiefs and 
farmers, and the erosion of traditional controls on chiefly administration. Section three contains a brief introduction to the courts system of Ghana, its bottlenecks, problems of access, and litigants' reasons for turning to a state court. Section four then analyzes judicial customary law in court cases dealing with stool land. Special emphasis is put on security of tenure, power of alienation, and the role of the chief as custodian. This chapter in section five concludes with the non-conformity of local practices with customary land law as pronounced in state courts, and tries to explain this gap by demonstrating the legal and political causes.

\section{Struggles for land in peri-urban Kumasi}

\section{Chiefs}

Most Ashanti chiefs ${ }^{7}$ claim to have the authority to take farmland in which community members have a usufructuary interest, convert it into residential land, and lease it to strangers. ${ }^{8}$ These claims are supported by two dominant legitimizing discourses. A first discourse by chiefs holds that the abovementioned customary rules - protecting the usufructuary interest in land against anyone including the chief - date from the days when communities were involved in subsistence farming in land abundant areas; however, these rules have become outdated now that urbanization and population growth have enhanced the value of land. Therefore these rules need to be adjusted to modern circumstances, in the sense that when communal land can be used in a more productive way, it should be brought back into chiefly administration; the chief will then centrally organize the conversion. In the words of the Beseasehene: "It's a law that when the town is growing and it comes to your place, you don't have any land, because the land is for the chief. Therefore the community can use this land." 9 These claims seriously weaken the tenure security of the usufructuary: any time there is a demand to change the use of land from agricultural to residential, the chief can claim the right to reallocate their farmlands.

Among some of the chiefs, an even more far-reaching discourse is found. These chiefs claim that stool land does not belong to the community as a whole, but to the royal family only, "since they were the ones fighting for the land." Iо "The land belongs to certain families. They fought for it or got it from the Asantehene or Ejisuhene because of for instance marriage. If your forefathers did not have land, you can't claim it now." "II This feudal claim is facilitated by the fact that the word 'stool' is used in different contexts, sometimes denoting the whole indigenous community, other times only the office of the chief or the royal family. In this discourse, the royal family had only given the land out 
for farming purposes, to temporary caretakers, and can at any time reclaim it when its use is changed to residential. Obviously this line of reasoning leaves no obligation on the royal family to compensate the farmer or use the revenues in the general interest. "The farmer does not lose any land, since he never owned any land. The farmer is only the caretaker for the chief. The land was given to him free of charge, so how can he claim part of the money when it is being sold?"I2 "The division (of land revenue) depends upon the leniency of the chief. He can decide to take everything himself." "I3 This narrowing down of the land-owning community degrades the nature of the customary rights of usufruct. The freehold is transformed into a permissive right of tenant-like character, based on the leniency of the chief instead of on the communal ownership of the land. Obviously, this severely diminishes the security of the usufructuary rights. The allodial title proportionally gains in weight and it shifts from the community as a whole to the royal family, on whose behalf the chief now claims outright ownership. ${ }^{\text {I4 }}$

\section{Farmers}

Besides the chiefs, indigenous farmers and families are the main actors in local struggles and negotiations for land. Some farmers, families or communities accept the fact that the chief is converting and leasing out their farmland, although they often do try to influence the division of the revenue accruing from the lease. Many others, however, do not agree to and try to resist the chief leasing out their land at all. Resistance takes many forms: public consultations with the chief at village meetings; private consultations between farmer or family and chief or with the involvement of members of the local Unit Committee or the assembly member of the village; ${ }^{15}$ farmers or families selling their own land before the chief can do it; making threats of destoolment against the chief or actually destooling him; ${ }^{\mathrm{i} 6}$ violence against the chief; chasing off the buyer when he comes to develop the land. These acts of resistance are sometimes successful, sometimes not. The varied outcomes depend on factors such as the approach taken by and the power, position, and personality of the resisting actor; the personality and power of the chief; and the ability of both parties to build coalitions within the community and to mobilize support outside the community, notably at higher levels of chieftaincy and from the government. A number of short case studies are described to make this point clear.

In the village of Brofoyeduru, on the road to Obuasi, strangers started to ask for residential land approximately I5 years ago. At first it was the chief demarcating the land and leasing the plots out to strangers, without paying any compensation to the farmer who lost his land. 
But after a while, his sisters went to talk to him, and he allowed first one and then all of his siblings to convert and lease out their own land. When word got out, other people in the village also started to do that. The chief is not protesting. He signs the allocation papers of the farmers, for which he receives a signing fee. In the village of Tikrom, a few kilometers off the road to from Kumasi Accra, the chief has been steadily converting and leasing out village farmland. The community, led by the Unit Committee chairman and the assemblyman, has tried to talk to him to get him to agree to give a certain fixed percentage of stool land revenue to the village for development projects, but unsuccessfully. The community has sought publicity on a local radio station; has written a letter to the Asantehene; has appealed to the Asomenyahene, the chief of their hometown, to intervene; and has brought in the Environmental Protection Agency to stop the chief from sand winning close to the streams. All to no avail. A large part of the farmlands in the village are now sold, and the villagers have not seen any community development, but for the construction of a primary school, which was funded by the EU.

The village of Besease is situated on the main road from Kumasi to Accra, approximately 23 kilometers from Kumasi. The Beseasehene has already converted and allocated most of the farmland of his own family. Looking for new sources of revenue, he is now trying to allocate land of other families in the village. He has for instance allocated two plots of land belonging to the lineage of his Kontihene subchief. The Kontihene and his elder made the following remark about these allocations: "The Beseasehene has no say in our land. I also have a black stool, so I am next to him, not subject. We have challenged him. But we, as the rulers of Besease, do not want to take him to court. But the buyer cannot come and work on the land. If he comes to work, he will meet the Konti. He will either get part of his money back from the Beseasehene, or maybe get only one of the two plots. Or he will pay some extra 5 million Cedis to the Konti to be allowed access to the plots (that were sold for Cedis I5 million). We want that person to summon the chief in court."I7 Beseasehene has also allocated one plot of land of a different family to a stranger. When the stranger came to develop his plot, he was chased off by the farming family. When the stranger complained about this to the Beseasehene, the chief went to the family "to plead with them to settle the case", but the family nearly beat him up. The chief then refunded money to the buyer. ${ }^{\text {I8 }}$

Besease does not only house the Beseasehene and his subchief the Kontihene, but also three of the subchiefs of the Ejisumanhene, the paramount chief of the area. One of these subchiefs is the Kyidomhene. An elder of this lineage, and the next in line to become Kyidomhene, has recently allocated seven plots of family land to pay for the re- 
novation of the family house. When asked whether permission of the chief is needed to lease your land to a stranger, Mr. D, the elder, answered: "Things are changing. It depends upon the animosity. The chief has to sign the land allocation paper and the site plan. But we first sell and then we go to the chief." "I9 He later explains that his family consists of three houses or gates, from which the chief is selected. The people from these three gates can sell their own land, whereas the others cannot. $^{20}$ According to the Kyidomhene, however, "D was wrong when he said that members of the three gates can sell their own land. He says that because he has sold seven plots. It is the chief who will sell the land and divide the revenue." Mr. D, however, is not on a bad footing with the Kyidomhene, since D did not connive with the paramount chief, when the latter wanted to get the Kyidomhene destooled and D enstooled as new Kyidomhene. No formal actions were therefore taken against Mr. D on account of the land sales. Another of the subchiefs of the paramount chief residing in Besease is the Gyaasehene. Recently the Gyaasehene has been selling land without the knowledge of his family members who were farming on that land and also without paying them any compensation. A family member explained that "If you are very difficult, the chief cannot take your land away. You can sell and give part of the money to the chief. But if you are unlucky the chief will take it, and if you don't fight it, you don't get anything." Now that she knows the Gyaasehene is selling land without consent of the farmers, she will prepare a plan when the town starts to reach her land, because "that gives me the possibility to fight."2I

The short cases described above clearly show that the peri-urban area of Kumasi is an arena of severe and protracted negotiations and struggles over land. Practices regarding customary land are thus more negotiated than based on clear and unambiguous rules of customary law (cf. Berry 200I; Chanock I998; Comaroff and Roberts I98I; Mann and Roberts I99I; Moore I986; Oomen 2002; Otto I998; Ranger I983; Roberts I979: I82; Von Benda-Beckmann I979). Customary law, or rather interpretations or claims of customary law, should be seen as one of the resources actors in these struggles use. Actors try to use the somewhat flexible, unwritten nature of customary law to legitimize their actions and defend their interests. Chiefs and elders do so explicitly, farmers more implicitly. But the negotiations over land are and always have been power struggles, to a high extent influenced by other factors, such as historical narratives, personalities, and social and economic capital. 


\section{Traditional Controls on Chiefly Administration}

Despite many acts of resistance, chiefs are often able to re-appropriate a considerable proportion of stool land and to lease those plots to outsiders. This is strongly connected with a shortage of checks and balances on chiefly administration on the one hand and a lack of accountability on the other. Authoritative writers have described a number of customary checks and balances on the performance of chiefs in Ghana, such as the fact that chiefs ought to take decisions in council with their elders or subchiefs, and the possibility to destool a seriously malfunctioning chief (Busia I95I; Danquah I928; Hayford I970: Ch. 2; Kasanga and Kotey 200I; Kofi-Sackey I983; Obeng I988: Ch 7-II; Ollennu I962; Ollennu 1967; Pogucki I962; Sarbah I968). ${ }^{22}$ They seem, however, to depict an idealized version of customary law rather than effectively functioning checks and balances in present-day village practice in peri-urban Kumasi.

According to customary law, a chief can only bind the community if he acts with the consent and concurrence of the whole community represented by the principal councilors from all major families of the community (Busia I951: I4; Hayford I970: 73; Ollennu 1962: 130). Therefore, the chief is controlled in the enjoyment of the communal lands by his councilors, called elders or subchiefs (Pogucki I962: I82; Sarbah I968: 66, 87). A chief who repeatedly ignores the advice of his people, especially of his councilors, is liable to destoolment (Danquah I928: 57, II6). Current practice in peri-urban Kumasi shows an entirely different picture. In a number of villages, the councilors are selected from the royal family only and not from all major families of the community. Furthermore, when elders criticize their chief, in many villages the chief does not listen to them. "Beseasehene is a new chief. He doesn't mind the rules. I tried to talk to him, but he didn't take my advice. If I wasn't educated, he would try to cheat me as well." ${ }^{23}$ In other villages, the chief co-opts his elders by sharing the benefits from land administration with them, removing their incentives to effectively check the use of power and if necessary stand up against the chief. "The subchiefs support the chief, because they get a share of the money. When they argue with him, they won't get anything." 24 "The natives of the town have to try to stop the chief from malpractices. If you attack him constantly, he has to change. This is usually done by the elders, but in many villages the elders connive with the chief." 25

When the people of a community want to destool their chief, a case has to be brought to the Traditional Council, constituted of the paramount chief and his subchiefs. ${ }^{26}$ Removing a chief thus always requires the involvement of other chiefs. This can be complicated. Paramount chiefs often have a direct interest in the person who will be 
elected to occupy the village stools, mainly because of their claims to a share of the villages' land revenues. But even if paramount chiefs do not have such an agenda, it is still chiefs judging their fellow chiefs. Many of the current destoolment charges have in one way or the other to do with land administration. And often the charges against the chief-on-trial, such as not using enough stool land revenue for community development, are also items of contestation in the villages of the judging chiefs. Often their personal interest in such cases therefore stands in the way of objective and impartial judgments. Besides the fact that other chiefs always have to be involved, an additional obstacle to destoolment is that, according to customary law, charges cannot be brought by commoners, but only by the 'kingmakers', i.e., those subchiefs and members of the royal family who can also make or enstool a chief (cf. Hayford I970: 36). As discussed above, these subchiefs are often restrained by their proximity to the chief or co-opted and therefore not likely to take the lead in actions against the chief. And if they do dare take action against their chief, this is only "after many years of wrongdoing. The chief will first be given the benefit of the doubt.",27 When you add to those waiting years the years the destoolment procedure itself may take, one can imagine that a chief can alienate a considerable amount of stool land in those years and spend the proceeds as well.

The main customary checks and balances on chiefs - ruling in council with subchiefs and the possibility of destoolment - are thus not very effective. One can add to this the fact that chiefly accountability is extremely low. Through a lack of registration most land administration is concealed. A good chief may account to the people for his administration on his own accord, but this is an exception rather than the rule. Some people claim that "nobody has the right to ask the chief to account" 28 and "[I]f it goes wrong, there is nothing to do about it." 29 This is often explained by the fact that the chief also has his professional income, and therefore one does not know whether he is spending personal or stool money. Or it is said that "the chief does not receive any remuneration, but he does have job-related expenses, to which the people do not want to contribute;" 30 the chief continues to bear obligations for which the customary provisions, such as the chief's right to portions of skins of wild animals, tributes of fish, and communal work on his farm, have ceased (Annor 1985: 157; Busia 1951: 44). ${ }^{3 \mathrm{I}}$ Others claim that to ask a chief to account to the people is considered a vote of no confidence - "If a chief does his work well, no one will ask him to account" 32 - and most people will not dare to do that unless there are more than clear indications of serious misrule by the chief. And even then, 'who is to bell the cat?' The chief is still a powerful fig- 
ure in most villages and you are sure to bring his wrath upon you by agitating against him.

Besides by traditional controls, chiefs could also be constrained by governmental checks and balances. Although such state controls exist on paper, this chapter discusses in section five under the heading 'the political factor' why they are hardly effective in reality.

Considering the difficulty of resisting the chiefs from re-appropriating and leasing stool land and the weak accountability of chiefs over their administration and the revenues, it is worthwhile to examine to what extent state courts serve as an alternative channel for resistance to indigenous farmers, families, and communities. As said, this depends on the one hand on people's access to and the functioning of state courts, and on the other hand on the decisions reached by these courts and their execution. These issues will therefore be discussed in the next two sections.

\section{The court system and its bottlenecks}

The Ghanaian court system currently consists of the superior Courts of Judicature - the Supreme Court, the Court of Appeal, the High Courts and the Regional Tribunals - and the lower courts - the Circuit Courts, Circuit Tribunals, and the Magistrates Courts. ${ }^{33}$ The Magistrate's Court is the lowest level of civil court which hears land cases. In the peri-urban areas, however, most land cases start in the High Court. ${ }^{34}$ From the High Court an appeal lies at the Court of Appeal and from there at the Supreme Court (Brobbey 2000).

The state courts - especially the Magistrates Courts and the High Courts - have been in a state of crisis for some years. Although this is a generally acknowledged fact in Ghana, there is little research on the functioning of state courts, in particular from a people's perspective. A positive exception to this rule is the research done by Crook, who has undertaken an in-depth study into court use in Ghana, with a survey among I86 litigants in land cases in Kumasi High Court, Io in Wa High Court, and 47 in Goaso Magistrates Court (Crook 2003). The courts are overwhelmed with the large volume of cases, of which land cases form a significant proportion. ${ }^{35}$ Few of these land cases can be heard or settled within a reasonable time, causing a huge backlog of unheard cases and long delays for litigants. According to Justice Georgina Wood "land litigation in Ghana has been found to be a complete nightmare" (Wood 2002: I). It is a nationwide problem that the rate of disposal of land cases is far lower than the rate at which these cases are filed in the courts (Kotey, Dowuona-Hammond, and Atuguba 2004: 78; Wood 2002). ${ }^{36}$ According to Wood, for a case to travel 
through the entire hierarchical court structure takes an average minimum of 3-5 years and a maximum of 8-I5 years (Wood 2002: 2). ${ }^{37} \mathrm{~A}$ farmer narrates his experience with the court: "I went to court and it took more than five or six years. Then the lawyers advised me to settle the case at home. I was sure that I would win, but there was an injunction on the cocoa farm and that cost so much that settling would be cheaper." 38 The number of times litigants have to come to court is also problematic. In Crook's research $40.9 \%$ of the respondents said they had attended court more than 2I times since the case began - often only for the case to be adjourned without a hearing - 6.I\% even claiming they had attended more than Ioo times (Crook 2003: 9).

These adjournments are largely caused by lawyers, witnesses or even parties simply not turning up when their cases are scheduled, or in the case of lawyers turning up insufficiently prepared. ${ }^{39}$ But there are also a number of administrative and procedural problems causing adjournments and backlogs: insufficient number of judges, caused by unattractive salary and working conditions; the very small percentage of out-ofcourt settlement; ${ }^{\circ}$ too much reluctance to bring summonses for attendance and to move cases to be struck out for lack of suit; ${ }^{4 \mathrm{I}}$ over-optimistic scheduling of hearings - up to 20 or 30 cases a morning; 'missing' dockets, either because of inefficiency or because of corruption by court staff on behalf of one of the parties; not enough working months due to long holidays; and parties who do not know when the date and time of the next hearing is (Crook 2003: 9-IO; Wood 2002: 4-9).

An additional obstacle for many people is to gain access to the system. Abovementioned bottlenecks of duration of cases and number of times a litigant has to come to court - usually accompanied by a lawyer $^{42}$ - have obvious implications not only for time but also for the costs. ${ }^{43}$ In Crook's research, $70 \%$ of the litigants had spent between Cedis 500.000 and Cedis 5 million. Although he concludes that these costs are not as out of reach for a family or somebody with a farm or business as might have been expected, for subsistence farmers this amount could severely hamper their access to courts. ${ }^{44}$ Kotey et al. show that while the costs of initiating land cases is quite low they can seriously mount up during the case. Some of the litigants are therefore later unable to continue with the case for financial reasons, again causing delays, adjournments and backlogs (Kotey, Dowuona-Hammond, and Atuguba 2004: 104).

In addition to the financial aspect, there is also an emotional side to access. State courts are often said to be remote from the villages, both in physical and emotional distance. The culture of the court can be alien, unintelligible, and intimidating for many Ghanaians. Crook qualifies this criticism by stating that, although the core of the legal system indeed remains the English common law, the courts have been operat- 
ing in Ghana for over a hundred years and their procedures have in many respects been 'Ghanaianized.' The language has also been adjusted: whereas the recording is done in English, most hearings are held in a combination of English and the local language. ${ }^{45}$ In Crook's survey, $82 \%$ of the respondents said they had understood the proceedings, and over half of all respondents described the judge in positive terms. ${ }^{46}$

With regard to disputes involving a chief, there is another possible obstacle for bringing such a case to court: state courts have no jurisdiction in a "cause or matter affecting chieftaincy." 47 This is interpreted as any cause, matter, question or dispute relating to the nomination, election, selection, installation, deposition, or abdication of a chief. ${ }^{48}$ As a consequence disputes over stool land that are related to charges for destoolment cannot be dealt with by state courts. In peri-urban Kumasi the access to state courts when chiefs are involved is even more impeded by the appeal of the Asantehene to withdraw all land cases pending at the state courts, to bring them to his 'court' for dispute settlement. ${ }^{49}$

Nevertheless, in spite of difficulties of access, expense, and delays, state courts are resorted to by very large numbers of litigants in land cases (Crook 2003: 5)..$^{\circ}$ 'Going to court' is not only for the rich, powerful, or highly educated; a wide range of ordinary citizens use the courts..$^{5 \mathrm{I}}$ According to Crook, the main reasons for choosing the state court are the perceived need for authority and certainty and a suspicion about the impartiality of arbitration..$^{52}$ Many people also stated that arbitration cannot be enforced. ${ }^{53}$ Because of the high number of land cases, courts are in a position to play a significant role in enhancing the tenure security of subject-farmers. ${ }^{54}$ This depends both on the kind of decisions and the rules of customary law the courts pronounce, and on the execution of the judgments in the localities. Unfortunately there seems to be no literature available on the execution of judgments in Ghana. The fact that execution is not discussed, both in Crook's research and in some other critical analyses of the functioning of Ghanaian courts ${ }^{55}$ seems, however, to imply that execution of judgments is not a major problem area in Ghana. This chapter will therefore acknowledge the need for further research in that area and leave execution out of consideration. The next section focuses on the pronouncement of rules of customary law in land cases in the Ghanaian courts, i.e., on judicial customary law. 


\section{Customary land law in the courts}

The state courts are constitutionally endowed with the power to apply all the rules of law recognized in Ghana, including customary law (article II of the 1992 Constitution). ${ }^{56}$ In this section, the application of judicial customary land law is analyzed. This will show how Ghanaian courts answer questions regarding competing claims for land by chiefs and community members; tenure security of usufructuary rights in land; the power of alienation of these rights; the role of chiefs in land administration; and their accountability in this process. ${ }^{57}$ It draws on reported cases - available up to I996 and for the Supreme Court up to $2002^{58}$ - and unreported cases from 1995 until 2004, studied at the Council for Law Reporting in Accra and collected at law firms in Accra and Kumasi. ${ }^{59}$

\section{General Rules}

According to state courts, the allodial title to every portion of stool land in Ghana is vested in one of the customary communities. It is also described by such terms as the absolute, final, radical, paramount, or ultimate title. Any community member has the right to occupy a vacant portion of the stool land to develop a plot "by cultivating it in one form or another, by building on it, or using it in any other way in which an owner would use his land." 60 The member then acquires an interest, called the usufructuary, ${ }^{6 \text { I }}$ determinable, or possessory interest, or the customary freehold. The term customary freehold is enshrined in various statutes, such as the Land Title Registration Law, I986 (PNDCL I52). However, in line with the terminology in most dicta, this chapter uses the term usufructuary interest.

Several cases have held that when it comes to rural and farming lands, no express grant is required from the community holding the allodial title. ${ }^{62}$ The members occupy and use the land by implied grant. With the reduction in the area of vacant land, however, the members have been subjected to more control (Woodman I996: 90). In the case of urban or peri-urban lands where the demand for land is higher and there is a need for orderly development, it has become relatively common for members to seek an express grant from the allodial title holder. ${ }^{6}$ For instance, in Oblee v. Armah (1958) it was held that:

"the general rule that a stool-subject does not require the consent of his stool, when seeking to occupy vacant stool land, gives way where the land is outskirt land of an urban area and is ripe for development. (...) In the case of such lands, express permission is always required, and limits are set to the extent of land 
which one subject may occupy, in order to maintain proper administration of the land and ensure that each subject who requires land to build gets his fair share." 64

Under certain circumstances, express grants may even be necessary in respect of some farmlands. In Frimpong v. Poku (1963) the Supreme Court held that:

"The principle of customary law which says that a subject is free to cultivate any extent of stool land does not confer on a subject an unlimited license for indiscriminate cultivation, and a subject usually obtains the formal permission of the stool for the purpose. Permission is never refused but it is necessary in order to enable the stool to keep a check on cultivated areas. In days gone by when land was plentiful and persons seeking to cultivate it were few, a subject would be shown a site or would choose his own site with the approval of the stool, and he could then extend his cultivation to wherever "his cutlass could carry him" as the saying goes. In modern times, however, it has become necessary to ensure a more equitable distribution of available land for cultivation and the practice has been for limited areas to be demarcated for subjects of the stool." 65

And in Amatei v. Hammond (I98I) it was held that:
"where a subject of a stool requires land (...) and engages him- self in commercial mechanized farming he should be required to obtain an actual grant in the form of a lease. If such a person with the necessary resources and equipment is permitted to rely on this inherent right to clear miles and miles of stool land, it would not be long when other subjects of the same stool would be deprived of any share of the land." 66

Although it has become relatively common for members to seek an express grant from the allodial title holder, this does not mean that the creation of the interest is dependent on the obtaining of such a grant (Woodman 1996: 90-I). There may even be a right to receive that grant on request. ${ }^{67}$

Other issues include whether interests created through express grants differ from interests created through implied grants, and whether allodial title holders can attach certain conditions to express grants. In I95I, Jackson J. held in the Kokomlemle Consolidated Cases ${ }^{68}$ that the ususfructuary title which a subject of the Gbese stool acquires in Gbese Stool land upon express grant confers upon him only farming 
rights and nothing more. According to Ollennu this case was upheld by the West African Court of Appeal ${ }^{69}$ in two cases (Ollennu ig62: 56). ${ }^{70}$ In Woodman's opinion, however, these cases did not discuss the correctness of this part of Jackson J.'s judgment (Woodman I996: IooI). In any case, Jackson J. seems to have erred in his earlier opinion ${ }^{7 \mathrm{I}}$ and went back on his statement in a later case. ${ }^{72}$ In this judgment of I952 he interpreted the subject's title - which he called farming right as follows:

“ (...) which right includes all the incidents of living, whether by residence on the land by members of the family or by leases of the land to strangers, i.e. so long as they do not alienate the land from the stool of which they are subjects."73

This judgment seems to represent the current legal opinion. For instance in Thompson $v$. Mensah counsel for plaintiffs argued that when a subject obtains an express consent of the stool to occupy stool land, the stool can prohibit the alienation of the usufructuary title without the previous consent and concurrence of the stool. But this was not accepted by Ollennu J., who held that such a condition would be void and unenforceable, since it is a violation of the subject's inherent right to occupy stool land without any burden except the recognition of the title of the stool which carries with it certain customary services. ${ }^{74}$ In Oblee v. Armah Ollennu J. also argued against conditional grants, stating that "the rights exercised by a stool-subject over land in his occupation are not limited by the purpose for which he has acquired the land or for which it was demarcated in his favor. Thus where a stool-subject occupies or is granted land for farming purposes he is not thereafter restricted to farming in his use of the land."75 Presumably based on increasing awareness of the need for planning, High Court Kumasi decided in 1997 that when a subject wanted to change the nature of the land from agricultural to commercial, he did need an express grant from the stool. ${ }^{76}$

In conclusion, areas with pressure on land show a trend from implied to express grants. It seems, however, that according to judicial customary law allodial title holders do not have the ability to use express grants to alter the usufructuary interests of community members.

\section{Security of Tenure}

In many cases it has been asserted that the usufructuary interest is a potentially perpetual interest: when a usufruct has come into existence, the stool has no power to grant conflicting rights to anyone else unless 
the interest-holder consents, and the interest is lost only by abandonment, forfeiture, extinction by operation of legislation (compulsory acquisition by the state), because of failure of successors, or with consent and concurrence of the interest holder. ${ }^{77}$ For instance in Total Oil Products v. Obeng (1962), a case concerning a lease by a stool to a stranger of land in the possession of a subject of the stool or his grantee, High Court Accra stated that this practice was "absolutely against customary law."78 And in Mansu v. Abboye (1982-3), Francois J.A. held that "(it is) a hallowed canon of customary law, that stool subjects in possession can only be dispossessed of their usufruct in land with their consent or on proven and unrectified breaches of customary tenure, or upon abandonment." 79 The usufructuary can sue the stool for a declaration of title, damages for trespass, or recovery of possession. ${ }^{8 \circ}$

In a few cases it has been suggested that the stool may have some powers to deprive the usufructuary of his rights (Woodman I996: I07). Woodman cites a I9II case that held that a person who buys land from the community may dispossess a member on the land in return for reasonable compensation. ${ }^{81}$ And a 1949 case held that "there was some authority for the view that the cultivator could be compensated for his trees, after a proper valuation, instead of continuing on the land. The defense had not however proved that they had such a right in this case." 82 Yet according to Woodman, these cases appear to be contrary to the numerous dicta stressing the security of title. ${ }^{83}$

Another decision suggests that a community has the power to exchange land held by a member. ${ }^{84}$ In this 1950 case the chief of the Brazilian community of Accra claimed the right to alienate, free of all interests, land which had been cultivated by a member. The case was dismissed, because he failed to show a decision by the community to convey the land. But Coussey J. held:

"If the plaintiff had shown that the elders of the (...) community had concurred with him in selling land for the benefit of the community and that they had resolved that in the interests of the community the defendants' occupation should be shifted to three other plots of land, he might have been entitled in certain circumstances, subject to the defendant's interest being defined, to a declaration."

In a later similar case (I959) a chief claimed that he could exchange land in the possession of a subject because the area was laid out for orderly development. This was rejected by the court:

"It is difficult to appreciate this argument. Once land has been granted to a person, it cannot be taken away from him and other 
piece given him in substitution without his consent. The grantor would be acting unlawfully if, without the consent of the grantee, he should grant the original land to another person, allocating another piece of land to the original grantee. And the party to whom a purported grant of such land is made would be guilty of trespass if he entered upon it without permission of the original grantee." 85

In another case, in 1961, defendants claimed that the people, chief, and elders of two towns had agreed that no compensation would be paid for any farms which might be destroyed in the process of raising a new township. High Court Accra held that such an agreement which interfered with vested individual private rights is ultra vires. For an individual to be deprived of his rights in property it must be shown that he personally agreed to waive that right. ${ }^{86}$ In Total Oil Products v. Obeng ${ }^{87}$ counsel for the plaintiffs raised the point that subjects of a stool traditionally had an inherent right to the exclusive use of a portion of stool land in return for war services. Now that subjects are no longer called upon to lay down their life to acquire or preserve stool land, their rights to stool land are at the will of the stool. Therefore the stool could alienate land in the possession and occupation of a subject without reference to the subject-owner. The High Court rejected this argument and there has been no other attempt to establish that the member holds at the will of the community (Woodman I996: 108).

\section{Security of Tenure in Peri-urban Areas}

Because of the peri-urban practices as described in earlier sections it is interesting to look specifically at court cases dealing with land that is being converted from farmland to residential land. In Baddoo v. Botchway (I949) it was held that this change in the category of the land causes the member's title to lapse. ${ }^{88}$ But this decision was based on the view that a member who received a grant of vacant communal land from the community was a mere licensee without a power of alienation, and this would be regarded as bad law today (Woodman I996: I09). In four cases decided in 1959 and I96I the same argument was rejected. ${ }^{89}$ For instance in Ashieoma v. Bani (I959) it was held that "the Court of first instance was right in rejecting the alleged custom by which a landowner was divested of his title when his land became outskirt land (and) that such a custom would be contrary to natural justice, equity and good conscience." ${ }^{\circ}$ However, in 1979 it was suggested by Edward Wiredu J. in Amatei v. Hammond that these holdings should be "looked at again": 
"Where an outskirt land in possession of a subject is required for general development of the community such as for building a school, lavatory, etc. or where as in this case, the area already in the occupation of the plaintiff had been carved into building plots for the use of the general community and the complete lay-out of the area has changed, I am of the view that the subject's prior occupation should give way subject, of course, to preference being given to him in the allocation of such plots if he requires one to build or in the alternative another suitable area given him in place of the one lost and his consent should not be a prerequisite to the stool taking over control of such an outskirt land."9I

And in I997 High Court Kumasi decided a case where subjects of Trede protested against the surveying and selling of the land by the regent of Trede. ${ }^{2}$ Although the court held that the regent could not alienate the land because of a dispute between two stools about the land, it also stated that the subjects could not "hold onto their farmland as farming land when development of Trede reaches that area, as that will not be in the interest of the community at large." This case does not make any statements as to procedure, compensation, or division of revenue, but does seem to indicate that consent of the usufructuary is not necessary for a change of land use.

Despite these few exceptions, it seems fair to conclude with Woodman that "the courts have been unsympathetic to attempts to subordinate the interests of the individual customary freeholder (usufructuary) to those of the community" (Woodman I996: I09). And even where the courts did make such exceptions, they posed conditions such as that the land is required for the general interest of the community and that the usufructuary would be properly compensated with other land.

\section{Power of Alienation}

Under judicial customary law, the holder of a usufructuary interest may grant a tenancy to be held from the usufructuary as a landlord (Woodman I996: I00). The usufructuary may also seek to alienate his or her usufructuary interest outright (Id: IOI). Until I957, the general opinion was that alienation of a usufruct from a member to a stranger required prior consent of the community, and that consent could be given conditionally. ${ }^{93}$ From the I950s onwards there was a change towards the view that "usufructuary title can be transferred without the consent of the real owner, provided that the transfer carries with it an obligation upon the transferee to recognize the title of the real owner, and all the incidents of the subject's right of occupation, including per- 
formance of customary services to the real owner." 94 The change was mainly effected in decisions of Ollenu J., ${ }^{95}$ whose view was also expressed in 1961 by the Supreme Court ${ }^{96}$ and the Privy Council. ${ }^{97}$ In this last case Lord Denning held:

"Their Lordships have been referred to a series of decisions in the Land Court in recent years, affirmed on occasions by the Court of Appeal, from which it appears that the usufructuary right of a subject of the stool is not a mere right of farming with no right to alienate. Native law or custom in Ghana has progressed so far as to transform the usufructuary right, once it has been reduced into possession, into an estate or interest in the land which the subject can use and deal with as his own, so long as he does not prejudice the right of the paramount stool to its customary services." 98

Two decisions went the other way, including a decision of the Supreme Court in 1960.99 The idea that transfer of the ususfructuary title does not need the consent of the allodial titleholder, however, came to represent the dominant view. ${ }^{\text {Io० }}$ For instance, in 1997 the Court of Appeal held that:

"(a)1l the text writers and decided authorities agree that it is the owner of the possessory or ususfructuary or determinable title to land who has the right of alienation (...) without prior consent and concurrence of the paramount owner, so long as the alienation carries with it an obligation to recognize the title of the allodial owner and to perform customary services due to the allodial stool when called upon."Ior

Interestingly, this was decided not only in cases dealing with transfers of land for farming purposes, but also for residential purposes ${ }^{\mathrm{IO2}}$ and for a cemetery. ${ }^{\text {IO3 }}$

\section{The Chief as Custodian}

In most cases it is stated that the allodial title is vested in the 'stool.' ${ }^{\text {IO4 }}$ It seems incorrect to say that the title is vested in the chief (Danquah I928: 200; Woodman I996: I9I). However, it has been held that the chief is a 'trustee' or 'in the position of a trustee. ${ }^{\text {IO5 }}$ Woodman explains clearly why this word is "uninformative, and maybe even misleading":

"The word "trustee" is a common law term which signifies the existence of a trust, whereby one title to property, usually the le- 
gal title, is vested in a trustee, and a different, equitable title to the same property in a beneficiary. Customary law does not distinguish between legal and equitable interests in land, so clearly the term cannot be used in that sense here. The meaning closest to it would be that the interest was vested in the chief, but that the chief could not validly deal with it without the consent of the stool council. However, it is not normally said that title is vested in the chief at all, and indeed some of the authorities comparing the chief with the trustee state that title is in the stool. Thus the term trustee appears not to refer to title, but merely to emphasize the restraints placed on the chief as representative of the community." (Woodman I996: I9I-2)

It is more accurate to say that the chief, as the leader and principal representative of the community, is the custodian of stool land. He is required to act with the advice of the stool council, and failure to do so constitutes grounds for destoolment. It was long held that although the chief's activities are controlled by the council, he cannot be held liable for accounts. ${ }^{\text {IO6 }} \mathrm{He}$ could, however, be destooled and then required to render an account. As late as I98I, the Court of Appeal upheld the rule that chiefs could not be held liable for accounts, even though Charles Crabbe, J.S.C. admitted that:

"The circumstances of this case require that the appellants, i.e. the second defendant and the co-defendant, the occupant of the Kumawu stool, be called upon to account. More so, the co-defendant. I freely admit that his conduct is reprehensible, if not sordid. Yet, I am of the view that perhaps the Supreme Court, but certainly not this court, is the proper forum for the explosion called for. And at best (...) "legislation not litigation, is the only satisfactory way of delimiting the bounds of so complex a subject.",,'107

The facts of the case were that the chiefs and kingmakers of Kumawu in the Ashanti Region had fraudulently claimed and received for themselves compensation paid out by the government in respect of acquisition of Kumawu stool lands. Respondents, all of whom are subjects of the Kumawu stool, successfully instituted an action at High Court Kumasi for the recovery of the compensation. On appeal, the Court of Appeal accepted the trial judge's findings that the Kumawuhene had perpetrated fraud on the stool or oman of Kumawu. But it reversed the High Court decision on the basis of the facts that (I) at customary law, only a chief could bring an action to recover stool property; the plaintiffs, not being chiefs, had no standing to initiate the action; and (2) at 
customary law, a chief could not be taken to court by his subjects and asked to render accounts. ${ }^{\text {I08 }}$ The Court of Appeal did not accept the analogy of family property, in relation to which a previous Court of Appeal had decided that where the family elders for their own selfish reasons were not acting to save family property, other members would be allowed to litigate to protect such property. ${ }^{\text {IO9 }}$ This was harshly criticized in an article by Fui Tsikata, who claimed that:

"Here was even a stronger case, as findings of fraud were made against the head and at least one elder. (...) (T)he arguments invoked in support of the immunity rule are the need to (I) uphold the dignity of the head of family or chief, (2) protect them from frivolous actions, (3) preserve an area within which the community can take its own decisions, in its discretion, without being imposed upon by the courts. Surely, none of these takes us to the point that if the head of family or chief has fraudulently diverted communal funds into private hands, the courts will not protect those funds unless the head or chief is deposed. Anyone who has been involved in organizing against wrongdoers who are backed by established social connections and wealth will appreciate what tremendous difficulties the plaintiffs in this case must have surmounted even to have the action initiated. (...) Any attempt to depose the chief would have confronted infinitely greater obstacles."

He therefore concludes that: "We submit that the pronouncements of the Court of Appeal on the customary law rules ought not to be followed, and that it should take advantage of the next available opportunity to distance itself from them."

Whereas the Court of Appeal was unwilling to extend the exceptions adumbrated in Kwan v. Nyieni from family to stool property that was exactly what the Supreme Court did on appeal in I99.. ${ }^{\text {II2 }}$ The Supreme Court had to decide on two main issues: whether the appellants were competent to bring the action and whether a chief could be held accountable. With regard to the first question the SC held that the applicants were competent to bring the action because:

"the principle in Kwan v. Nyieni [I959] GLR 67, CA providing exceptions to the general rule that the head of family was the proper person to initiate suits for recovery of family land was not confined to land. Under customary law wherever those clothed with authority to protect family interests failed to do so but rather formed an unholy alliance or conspiracy to damage 
the interests of the family an urgent situation had to be deemed to have arisen allowing for a relaxation of rules and permitting more responsible members of the family to protect the endangered family interests. Since the respondents who should have protected Kumawu stool revenue formed an unholy alliance to enrich themselves at the expense of the state, their conduct which amounted to fraud disabled them from performing their duty in preserving Kumawu stool revenue. And it could hardly be expected that they would take steps on their own volition to refund moneys they had illegally appropriated or rather misappropriated. In the circumstances, it was only the plaintiffs who were the remaining entity capable of championing the rights of the state. Accordingly, the exceptions to the general rule in Kwan v. Nyieni (supra) applied to clothe them with capacity."

With regard to the second question, the Supreme Court held that:

"He (the chief) can receive no protection for his illegal conduct by relying on the traditional immunity from accountability. That principle cannot be urged as a cloak for fraud. Since it is a statutory imperative that moneys from stool land acquisitions should be lodged in a designated fund, it would be improper for this court to overlook a defalcation that illegally subverts this rule. The principle of non-accountability cannot be projected above statutory requirements to afford a viable protective umbrella." II4

Thus, although there is no general statutory provision allowing the chief to be sued for an account, ${ }^{\text {III }}$ the principle of non-accountability is overruled when a specific statutory provision - currently found in article 267 (2) of the I992 Constitution and section 2 of the Office of the Administrator of Stool Lands Act, I994 (Act 48I) - requires the revenue from stool lands to be paid into stool lands accounts.

\section{Courts and peri-urban practice}

In this section, we will compare practice in peri-urban Kumasi with judicial customary law and try to explain the gap between the two. Practice in peri-urban Kumasi displays the chief as the most powerful actor in local struggles for land. Chiefs are often able to re-appropriate stool lands - in which community members have a usufructuary interest with the aim of converting this farmland to mainly residential land in order to lease it to outsiders. As said previously, they try to legitimize their actions mainly with two discourses. The first discourse says that 
when land can be used in a more profitable way, the chief has the right to reallocate land and alter its use. The second discourse holds that the land belongs to the royal family instead of to the whole indigenous community, and this family can therefore reclaim the land from the farmers at any time. The second discourse explicitly dismisses any reason for compensating the farmer or using revenues for the welfare of the community. The first discourse, however, implies that the proceeds of the conversion are used for community development such as infrastructural or educational projects. Although most interviewed chiefs acknowledged that they have at least a moral obligation to use part of the revenue for compensation of the farmer and/or for community development, the actual practices differ considerably and on average the chiefs receive unsatisfactory marks from the villagers. ${ }^{\text {II6 }}$ Both discourses bring about serious tenure insecurity for the farming community members. Attempts to hold chiefs accountable for their administration of land and the revenue accruing from the conversions have proven extremely difficult in the research area.

Land practices in peri-urban Kumasi are not supported by judicial customary law as described in the preceding section. Customary law in the Ghanaian courts conveys an image of protection of the interests of the individual usufructuary against the chiefs' attempts to re-appropriate stool lands for 'development' purposes. First, usufructuary rights are quite secure. Second, the transfer of the usufructuary title does not need the consent of the allodial title holder. This seems even to apply when farmland is transferred for non-farm purposes, such as for housing or cemetery plots. And even if an express grant were needed to change land use from agricultural to residential, as was stated in one court case, ${ }^{\mathrm{II} 7}$ it seems that the community member has a right to receive this grant unless overriding communal interests prohibit it. Thirdly, chiefs can be held accountable for the way they use stool land revenues, since there is a "statutory imperative that monies from stool land acquisitions should be lodged in a designated fund."II8 What can be discerned in judicial customary law is a trend towards more power to the chief as administrator, ensuring sound town planning and more equal distribution of land through the instrument of express grants. This trend cannot be interpreted to mean that the chief has the power to deal with land upon his own volition, without regard for community interests or compensation for farmers.

This gap between the customary rules as laid out in the Ghanaian courts and peri-urban practice can be explained by two factors. First, the difficulties for judges to know what the rules of local customary law are and to 'translate' these rules from the local level to state courts. This will be called 'the legal factor.' Second, the limited effect of judi- 
cial decisions on peri-urban practice due to the political configuration at local and national level: 'the political factor.'

\section{The Legal Factor}

It is common knowledge that there is often a wide gap between customary law as pronounced in the courts - judicial customary law - and actual local practices (Cf. Allott I975: 89; Allott I977: II; Asante I969: I00; Chanock I989: Koesnoe I985: I05-7; Von Benda-Beckmann I985b: 77-95; Woodman I977: II5; Woodman I996: 46). This gap can be explained firstly by the difficulty of knowing what the applicable rule of local customary law is, and secondly by the nature of the state legal system, which inevitably transforms local customary norms. Interestingly, High Court judge Baffoe Bonny turned the argument around, saying that: "what is in the courts is the customary law. Local practice differs from customary law because of 'ignorance' and opportunity." Both aspects are dealt with below.

The first aspect is the difficulty for a judge to define the applicable rule of local customary law. Obviously this is difficult because each locality has its own customary laws, and judges rotate through the country. But more fundamentally the complication lies in the fact that within one locality there are always variations within and conflicts about what local customary law is. Customary norms should not be regarded as the expression of values of the whole group, but rather as representations of the interests of parts of groups, which are focused into normative statements to give legitimacy to these partial interests (cf. Chanock I989: I74). ${ }^{\text {I2O }}$ This makes it hard for courts to enquire locally after the appropriate local rule of customary law. For who are to be regarded as authoritative experts of customary law? Allot points out that apart from reasons stemming from their personal or group agenda, experts may also give a misrepresentation of local customary law because of a tendency to idealize the law, to present what it ought to be instead of what it is, and because of the connected failure to appreciate that the ancient traditional law has been modified by subsequent practice (Allott I975: 78). He furthermore shows the "contrast between the informality, the flexibility, the "political" bargaining quality and the unpredictability of dispute settlement and the precision of the norms which will be quoted by members of the same society" (Allott I977: Io). Under colonial rule, it was mainly the African ruling groups of male elders who were able to put their morality forward as 'custom' and whose claims were countenanced by courts and administrators (Chanock I989: I79, I84; McClendon I995). Although Ndulo claims that this 'male elderly bias' has not fully disappeared in the post-colo- 
nial period, the protection of farmers' usufructuary rights against chiefs qualifies this criticism (Ndulo I98I).

It is equally problematic for judges to deduce, by themselves, the rules of customary law from local practices. For not only dispute settlement - as Allott points out - but also out-of-dispute-negotiations show a flexibility and unpredictability, and consist of political bargaining embedded in power relations. Customary law, or rather claims as to what is local customary law, form only one of the resources used by local actors in such negotiations over land. So how should a judge deduce rules of customary law from the outcome of struggles over land, from local "customary" practices?

This is all connected to the opacity as to who is the lawmaker in customary law. Is it the people who by practicing a certain custom turn it into law, or is there a special role for chiefs in this respect? A Ghanaian researcher in an interview once said: “This Asantehene has said that all land belongs to him and that families and individuals cannot sell land. So this is now the customary law, which the courts should follow."I2I On the one hand, custom may confer on some person or body the authority to legislate. When that power is used, the result could be regarded as customary law because that is its source of legitimacy. On the other hand, the Ghanaian Constitution defines the corpus of customary law as comprising "rules of law which by custom are applicable to particular communities in Ghana." ${ }^{\text {I22 }}$ This seems to indicate that practice is essential to the creation of customary law, and that its continued observance is required to keep the norm in being (cf. Allott I975: 89; Allott I977: II). According to S.K.B. Asante:

"this definition postulates an empirical reference for the content of the law, reaffirming the truism that customary law is grounded on the customs actually prevailing in the community. There can be no retreat to a remote and unsullied haven of logically coherent juristic norms. The very nature of customary law makes reference to contemporary practice and usage in society an integral part of the legal process." (Asante i969: 99)

This brings us to the second legal factor located within the state legal system, which by its nature inevitably changes local customary law. For - despite the abovementioned reference to empiricism - in a common law system, once custom has been settled by judicial decision, its binding force depends on the doctrine of precedent. Today in the majority of land cases the courts do not look for local norms and usage, but to precedent for the rules and principles of customary law (cf. Woodman I996: 43). A divergence is therefore likely between judicial and local customary law. High Court judge Baffoe Bonny acknowledges this gap 
by saying that "even when I know better I am bound to follow case law." ${ }^{\text {I23 }}$ According to S.K.B. Asante:

“(A) meaningful and scientific clarification, as well as a purposeful application, of contemporary customary law has been menaced by a tradition which restricts the orbit of the law to the narrow confines of authoritative decisions, and strictly commits decision-makers of today to the dubious wisdom of past experience. Nowhere is this cleavage between textbook law and social reality more glaring than in the customary land law of Ghana." (Asante I969: I00)

Although precedent does not establish a fixed rule in perpetuity, ${ }^{\mathrm{I}}{ }^{2}$ the system does not provide the same amount of flexibility that characterizes local customary law, with its ability to respond to changes in social reality. ${ }^{\text {I25 }}$ The system of precedent has the tendency to somewhat 'freeze' the law at one stage of its development and complicate further change (Allott I975: 95). ${ }^{\text {I26 }}$ The notion of flexibility of customary law should, however, be used with caution. It can easily be - and often is misused by actors in local power struggles. An instance occurs in this chapter's description of how chiefs are trying to legitimate their claims to land with reference to "evolved" customary law.

The mere imposition of a state court, with the power to impose rules and to enforce decisions in disputes already transforms the fluid nature of customary law. Whereas in local dispute settlements customary rules set the 'parameters of the dispute' and the 'guidelines for decisions', in state courts these rules will be strictly applied and imposed (Allott I975: 73; Chanock I989: I80; Von Benda-Beckmann ı985a: 78, 87). Furthermore, state courts cannot capture the 'processual aspect' of customary law. For instance, African marriage should not be seen as an event or condition, but as a developing process, with many steps (Woodman I977: II7). For a long time, parties are in interim conditions being neither totally married nor completely single. State courts, however, will have to decide in a certain case whether a couple was married or not at a certain point in time. State courts often also ignore local variation. Either due to ignorance, or as a purposeful policy, judges have gradually integrated customary law over the years, leading to the evolution of a body of principles which they have proclaimed to be of universal application in the country (Asante I969: IOI; cf. Koesnoe I985: 98). ${ }^{\text {127 }}$

There are a number of additional reasons why courts have no alternative but to establish as judicial customary law rules which are not identical to local customary norms: I) it is impossible for the courts to convert all customary norms into legal rules. They will need to select 
from a large body of customary norms a relatively small number to be accorded judicial enforcement; 2) when social changes have left the relevant norm uncertain, the courts are compelled to act ahead of the customary norms and make law; 3) developments in other types of law binding on the courts prevent them from adopting some customary norms, although these norms may continue to operate in practice. For instance, the courts cannot recognize a customary marriage contracted by a person already married under the Marriage Ordinance; ${ }^{128} 4$ ) pressures to attempt to produce social change through judicial action are in practice irresistible; ${ }^{\text {.29 }}$ and 5) local dispute settlement institutions and state courts have different procedures, different rules of evidence, and a conflict at a state court must be formulated to fit the requirements of 'civil disputes', whereas in village institutions disputes tend to be formulated in terms of proper behavior and procedures behavior and procedures (Kludze I985: 97; Von Benda-Beckmann I985a: 80-82; Woodman I977).

It is often said that the fact that judges inevitably 'create' judicial customary law which differs substantially from local customary norms and local practices can affect the local legitimacy of court decisions (Allott I975: 89; Allott I977: II; Asante I969: Ioo; Chanock I989; Koesnoe I985: I05-7; Von Benda-Beckmann I985b; Woodman I977: II5; Woodman I996: 46). This does not, however, seem to be an important factor in explaining the gap between court decisions and local practice in peri-urban Kumasi. In fact, the protection of the usufructuaries by the courts is in close keeping with the perceptions of many local smallholders.

\section{The Political Factor}

Whether the rules of customary law as pronounced in the courts will be complied with in the local arena - outside of the direct scope of the decided case $^{\mathrm{I} 3 \mathrm{O}}$ - depends to a large extent on the political configuration at both the local and the national level. With regard to the local level we have already seen that stool land administration is characterized by chiefs in leading positions and the prominence of customary law. Local negotiations over land are fluid and intimately tied to fluctuating social and political relations. Norms and rules are sources of power, manipulated and used selectively by parties in these negotiations (Chanock I998; Comaroff and Roberts I98I; Mann and Roberts I99I; Moore I986; Oomen 2002; Otto I998; Ranger I983; Roberts I979: I82; Von Benda-Beckmann I979). The critical question is, which actor or group of actors has the power to issue definitions or is able to mobilize support - from community members, the traditional system, the state - for its version of customary law. Since chiefs are generally re- 
garded as authorities in the field of customary law and as guardians of stool land, they are in a strong position to point to 'custom' to acquire and legitimate power over land in the local arena. ${ }^{\text {II }}$

Furthermore we have seen that customary checks and balances on chiefly functioning have eroded. Theoretically, these checks and balances are supposed to constrain the chief in his administration of land and in his use of the pliability of customary law. But as we have seen, in many localities the customary notion of ruling in council with elders or subchiefs has been severely eroded, destoolment procedures are prone to difficulties, and accountability structures are lacking.

Finally, it deserves mentioning that in peri-urban Kumasi knowledge of state law and court decisions appears to be minimal. During my fieldwork, people hardly referred to legislation and case law to stake their claims. And when they did, they often quoted sections that did not exist: "It is a constitutional provision that the town receives thirty percent of stool land revenue" ${ }^{\text {,132}}$; "Land revenues are supposed to be divided into thirds, one part to the farmer, one part to the chief who signs the allocation paper and one part to the town. That is even in the Constitution."'333 The 'shadow of the law' thus seems minimal in periurban Kumasi. ${ }^{\mathrm{I} 4}$

With regard to the national level it is worth considering whether the government shows a clear commitment to curb mismanagement of stool land or whether they are reluctant to interfere in such matters. It is clear that the current government is providing hardly any checks and balances on local land administration. The "policy of non-interference in chieftaincy affairs' shows itself in governmental land management. The government continually emphasizes the sovereignty of the chiefs and the fact that land administration rests exclusively in their hands. An instance is the wording, drafting process, and content of the National Land Policy - the first comprehensive land policy ever formulated by the Ghanaian government - and its implementing Land Administration Program (Ministry of Lands and Forestry 1999; World Bank 2003a). Public consultation about the formulation of the policy and the program has been minor and there seems not to have been a wide and open discussion on the role of chiefs in the administration of stool land - including the tendency of chiefs to adopt landlord-like positions - and the possible checks and balances the state can put in place with regard to stool land administration (Alden Wily and Hammond 200I: 25). The 'policy of non-interference' also becomes clear in general governmental discourse: government officials at all levels regularly proclaim in the media that they will not "meddle in chieftaincy affairs", by which they not only mean chieftaincy disputes, but chiefly administration in general. ${ }^{135}$ Administrators, lawmakers, and policy makers also pay little heed to judicial customary law. They rather leave 
the interpretation of customary law to the locality or follow the practice of the most powerful local actors, the chiefs. It is not hard to understand that this governmental 'policy' gives additional legitimacy to the chiefs, provides them with ample leeway to administer land the way they please, and places the power to define customary law squarely in their hands.

This 'policy' is not surprising when one takes into account the political power of chiefs, who are still regarded as strongly influential, and "who are still vote-brokers, especially in the rural areas." ${ }^{136}$ Furthermore, the current tendency to fill chieftaincy positions with highly educated professionals, blurs the traditional distinction between state elite and chiefs, and creates new alliances between these two groups. The elite of the party presently in power, the NPP, is especially closely connected to the chiefs. Not only does it have its stronghold in the Ashanti Region, with its resilient chiefs, but president Kufuor himself is through marriage connected to the royal family of the Asantehene. Many members of the current government, up to those at high levels, are or have been chiefs or royal family members in their hometowns. ${ }^{\text {I37 }}$ A clear example of the pro-chieftaincy course of the NPP government is the current plan to 'return to the chiefs' land that the government has compulsorily acquired over the last decades, but which it has not yet put to its intended use. This returning to the chiefs is done without any conditions on the way the land should be used or that its revenue should be accounted for. In this way the government lacks any consideration for the community members who used to farm or live on this land.

This chapter does not allow enough space to elaborately discuss the functioning of state institutions involved in stool land management, such as the Lands Commission, the Office of the Administrator of Stool Lands, and the Town and Country Planning Department of the District Assembly. It suffices here to say that these institutions effectuate little control on chiefly functioning. They are severely hampered by a combination of factors. Internal factors include the lack of funds, qualified staff, equipment, and vehicles on the one hand, and mismanagement and corruption affecting their legitimacy in the eyes of the people on the other. Externally, the uncooperative behavior of the chiefs and lack of high-level government support to tackle that behavior also severely hamper the functioning of state institutions. ${ }^{\text {13 } 8}$

There are two additional ways in which the position of the chiefs is enhanced by the state. First, local government cannot bypass chiefs in local land use planning: planning schemes can usually only be drawn up with the cooperation of, or at least consultation with, the chief; ${ }^{139}$ and the District Assembly only issues a building permit when the applicant can present an allocation paper that has been signed by the 
chief. Second, article 267 (5) of the I992 Constitution could be interpreted as enhancing the position of the chief. This article provides that "no interest in or right over any stool land in Ghana shall be created which vests in any person or body of persons a freehold interest, howsoever described." There is considerable controversy as to how this provision should be interpreted, and whether it means to include customary freeholds. ${ }^{\mathrm{I}}{ }^{\circ}$ According to Da Rocha and Lodoh, "the tenor of this provision is that not even members of a stool, as from 7 January I993 (commencement date of the I992 Constitution) acquire a (customary) freehold interest in any land in Ghana in which the stool holds the allodial title. The provision is however silent on the transfer of existing freehold interest in such lands. The deduction is that the transfer of freehold interests in existence prior to 7 th January I993 is not prohibited by the constitutional provision" (Da Rocha and Lodoh I999: I-2). Toulmin et al. quote an unpublished court case - The Republic v. Regional Lands Officer, Ho, ex parte Professor A.K.P. Kludze, I994 ${ }^{\mathrm{I} 4 \mathrm{I}}$ - in which the judge as an obiter dictum seemed to confirm that the Constitution prevents any freehold interest being created over stool lands (DFID 2004: Annex 3). However, in Gyan's opinion, which was accepted by the Attorney General's Office, article 267 (5) does not prohibit the grant of a customary freehold in stool land, where the grantee or transferee is a subject of the land-owning stool (Gyan 2005). ${ }^{\mathrm{I} 2}$ The significance of this discussion lies in the fact that if the Constitution is interpreted to prevent the creation of customary freeholds "chiefs could feel justified in issuing only leases even to their own subjects (...) thus further eroding the rights of customary landholders and their ability to resist re-appropriation of customary lands for 'development' purposes by Stools which wish to cash in on peri-urban land values" (DFID 2004). Furthermore, it could then be argued that it would be illogical and unjust if the customary land holder can pass on his/her customary freehold to a stranger, since that would give the stranger a stronger title than he/she could get if he/she applied directly to the stool.

\section{Courts as Alternative Channel of Resistance?}

In response to the question posed in the introduction, this chapter shows that courts could serve as an alternative channel of resistance in individual cases for farmers in peri-urban Ghana whose land is being re-appropriated by the chief. However, notwithstanding the high number of land cases in the courts, many more land conflicts never reach the courts, either because of the lack of access or interest of the aggrieved parties, or because they are embedded in 'chieftaincy affairs', for which state courts have no jurisdiction. In peri-urban Kumasi this is even aggravated by the appeal of the Asantehene to withdraw all land 
cases pending at the state courts, to bring them to his 'court' for dispute settlement. In particular, cases dealing with chiefs' appropriation of peri-urban farmland for development purposes are only sporadically dealt with in state courts. Furthermore, court decisions in those cases that do reach the state courts do not seem to have much effect on local negotiations for land outside the scope of the decided cases. This is, firstly, because of the limited knowledge local people have of court decisions. And secondly, as we have seen, a combination of factors at local and national levels creates an arena for strong local chiefs, hardly constrained by local checks and balances, and barely controlled by the government. It is therefore not surprising that chiefs do not comply with the rules of customary law as set out by the courts that protect the interests of the usufructuary. As said before, customary law is only one of the resources in local power struggles over land, and a multi-interpretable one.

\section{Notes}

I Ohene is the word for king or chief in (Ashanti-)Twi, the indigenous language of the Asantes. Within the Ashanti Region each village chief (ohene or odikro) is subordinate to a paramount chief (omanhene), who again is subordinate to the Asantehene.

2 See for a description of relevant case law the section 'customary land law in the courts' in this chapter.

3 Forfeiture results from denial of the landlord's title.

4 In the villages close to Kumasi, this causes the near total disappearance of farmland, creating increasing income insecurity for community members. They are no longer able to grow their own food and generate some income by selling the surplus at the market. Most of the mainly lowly educated farmers become jobless or resort to petty trading. The food prices in these communities rise, leading to increased costs of living. Furthermore, locals cannot compete with outsiders with a formal job for a plot of land, making it very hard for them to find land for residential purposes in their own village. In the villages further away from Kumasi or the main roads the conversion process is in full swing, but there some farmland still remains within walking distance. Cf. Berry 2002a: I24; Hammond 2005; Kenton I999: 3I; Similar stories are told for other urban centers in Ghana, see Abudulai I996; Abudulai 2002; Alden Wily and Hammond 200I: I2, 3640; Hammond 2005; Kasanga et al. I996; Kasanga and Kotey 200I: I7-I8; Maxwell et al. I998; Wehrmann 2002: 26-32.

5 Struggles for peri-urban building land are not new. For instance McCaskie in his description of the expansion of Kumase between I945 and I950 already shows the unprecedented struggles over rights in land as people tried to assert title to potentially valuable building plots (McCaskie 2000a: Ch. V). These struggles were not conducted as exclusive affairs between chiefs. "Owners and occupiers, squatters and speculators, or indeed anyone who hoped to cash in on the building boom pitched into battle over rights in land. The lineages that made up the pre-colonial population fought each other over historical prerogatives and split internally over issues of family or personal control over prime building sites" (p. 2I4). "Rights in building land and the income to be gained from them was a key locus of conflict between chiefship and its opponents in this period. The objects of groups (...) were to attack chiefly authority by challenging its rights in 
land; to accumulate money from such activities for political and personal use; and - perhaps above all - to expose to public gaze the corrupt self-interest of the Asantehene and his associates in profiting from the building boom through their insistence on historic prerogatives of access to and control over land" (p. 219).

6 The terminological question here is a tricky one. Authors use a wide variety of terms and phrases such as 'local customs', 'living law', 'social rules', 'social norms which people customarily regard as binding upon them', 'sociologists customary law', 'practiced customary law' or 'contemporary practice in the social process' (Asante I969: 99; Ehrlich 1936; Oomen 2002; Woodman I977: II5). Each terminology has its own drawbacks. This chapter uses the term 'local customary law', in contrast with 'judicial customary law', and sees norms of local customary law as one of the resources in the struggles and negotiations that determine local practices.

7 In my field research not only II of the I2 village chiefs were of this opinion, but so were the Ejisumanhene, a paramount chief in the area, and the Asantehene, according to his land secretariat. A number of quotes illustrate this: "The king of Besease has overall power of the land. (...) It is a law that when the town is growing and it comes to your farm, you don't have any land" (interview Beseasehene, II May 2003); "It is only the chief who can lease land for residential purposes" (interview Gyaasehene of Ejisumanhene, I June 2003); "The chief is the total owner of the whole place" (interview Kontihene of Ejisumanhene, I January 2004); "It is the chief of the town who allocates land" (Interview Asantehene's secretariat, Io September 2003); "When the lands turn profitable, they turn back to the stool (interview Asantehene's land secretariat, 2 July 2003). At a stakeholder meeting about the construction of an inland port in Boankra, someone was talking about "our land". This enraged the Ejisumanhene, who grabbed the microphone and said that no one owned land but him (personal communication at workshop on "land law and its legal institutions", Accra, 5 September 2003). The literature mentioned above in note 7 shows that the same kind of claims are made by chiefs of other peri-urban villages, near Kumasi as well as other towns.

8 Chiefs have played a key role in giving out land to strangers since the rise of cocoa and cash crop cultivation. See for instance Polly Hill, who writes in 1963 that for at least a century chiefs in Akim Abuakwa have been selling land to strangers. This concerned unoccupied portions of land that chiefs could sell in order to pay debts incurred by their stool. This last condition, however, "as time went by, was more honored in the breach than the observance" (Hill I963: 139). Berry shows that the chiefs' rights to land and land revenues were already disputed in the early twentieth century: "Chiefs also had a penchant for treating cocoa rents as their personal income, rather than public revenue belonging to the stool, and for selling land or levying their subjects to raise money for litigation (...). Such practices occasioned widespread discontent and contributed directly to the increasing number of destoolments in the I920s and I930s" (Berry I993: II2). See for literature on the chiefs' role in giving out land to strangers and chiefs' contested rights to land and land revenue also Berry 1997: I233-I235; Berry 200I; Rathbone 1996.

9 Interview Beseasehene, II May 2003.

Io For instance Nana Sir Ofori Atta, the king of Akim Abuakwa during the most important decades of colonial rule, argued that Akim Abuakwa's monarchs had taken land by conquest; although the royal family had afterwards distributed the land to the divisions, they never relinquished their ultimate right to this land (Rathbone I996: 5II). The argument that it was the royal family that "fought for the land" is in contrast with a Ghanaian proverb which says: "In the fight, to secure the land and save the stool, no person's ancestor carried two swords, each carried one" - meaning that the ancestors of all community members including those of the occupant of the stool made equal sacrifices or contributions to win the land. And therefore each one has an inherent right to occupy 
any portion of it which is not already occupied by another community member (Ollennu 1962: 30).

II Interview Kontihene of Beseasehene, 23 October 2003.

I2 Interview former Akyeamehene subchief of Tikromhene, 7 January 2004.

I3 Interview Asantehene's land secretariat, 2 July 2003.

I4 See also chapter 3, p. 59-60.

I5 The Unit Committee and the District Assembly are the two lowest levels of local government in Ghana.

I6 A chief's throne is called stool. The installation and deposition of a chief are therefore called 'enstoolment' and 'destoolment'.

I7 Interview elder Besease Kontihene, 20 May 2003.

I8 Interview elder Besease Kontihene, 20 May 2003.

I9 Interview elder Kyidomhene, 7 May 2003.

20 Interview elder Kyidomhene, 22 May 2003.

2I Interview farmer Besease, 27 August 2003.

22 In an interview, prof Kasanga, the Minister of Lands and Forestry until mid 2003, insisted that "there are enough local checks and balances in the customary systems" (interview prof Kasanga, 3 December 2003).

23 Interview Kontihene subchief of Beseasehene, I July 2003.

24 Interview Unit Committee member Tikrom, 26 June 2003.

25 Interview Asantehene's Land Secretariat, 2 July 2003.

26 Due to section I5 of the Chieftaincy Act I97I (Act 370), which confers exclusive jurisdiction in any 'cause or matter affecting chieftaincy' to the Traditional Council, such cases cannot be taken to the regular state courts, only to the Supreme Court in last instance.

27 Interview Kontihene subchief of Ejisumanhene, 27 May 2003.

28 See a.o. interview 'father' of the Beseasehene, 5 June 2003.

29 Interview Gyaasehene subchief of Ejisumanhene, I June 2003.

30 Interview Jachiehene, 29 June 2003.

3I A complicating factor in this discussion is that a distinction should be made between the costs of administration of the stool and a personal emolument for the chief. That the community should bear the cost for administration of the stool is hardly disputed, but to what extent should the chief also receive a salary? In colonial times big chiefs received salaries according to their 'grade', but they were simultaneously under an obligation to account for their revenue through the Native Treasury (Crook I986: 90-94). Since independence, the chiefs have not received any salary from the government, but they do receive a percentage of stool land revenues from the Office of the Administrator of Stool Lands. This office disburses stool land revenue in the following proportions: twenty-five percent to the stool through the traditional authority "for the maintenance of the stool in keeping with its status"; twenty percent to the traditional authority; and fifty-five percent to the District Assembly (Office of the Administrator of Stool Lands Act 1994 (Act 48I)). The wording of this section implies that the twenty percent to the traditional authority can be regarded as personal emolument for the traditional authority.

32 Interview Okyeame subchief of Beseasehene, I2 June 2003.

33 Courts Act 1993 (Act 459), later amended by the Courts (Amendment) Act 2002 (Act 620). Magistrate Courts were set up only in 2002. Under the 1993 Courts Act the lowest court was called Community Tribunal and incorporated a lay panel of assessors besides a legally qualified magistrate - if such a person could be found in the area. For instance, in the Upper East Region the tribunal consisted of lay persons only (interview circuit court judge Wa, 20 July 200I; interview circuit court judge Accra, 7 August 2003). These tribunals were replaced by the amending Act of 2002 by Magistrate Courts that operate under a single legally qualified judge. The term Magistrates Court is a reversion to an older title, used for the District Courts created in 1958 . Since 1993 the Fast 
Track High Courts have been added to the system. These courts differ only in procedures.

34 Until 2002, the Magistrates Courts were limited to cases involving property not exceeding 5 million Cedis in value. In practice this meant that they did not hear any land cases in the urban and peri-urban areas which routinely started in the High Court. In 2002, the limit on Magistrates Courts was raised to 50 million, which is hoped to ease some of the pressure of the High Court. According to Crook, this is however unlikely, since the pattern of going straight to the High Court has become well entrenched, unless lawyers begin to advise their clients to use the Magistrates Courts for reasons of speed and cost (Crook 2003: 2).

35 According to Kotey et al., in the period I990-2002, land cases made up approximately $30 \%$ of all pending cases (Kotey, Dowuona-Hammond, and Atuguba 2004). According to Wood, land cases in 1967 already accounted for approximately $50 \%$ of the total cases filed nationally (Wood 2002: 2). In Kumasi High Court, land cases have accounted for an average of $45 \%$ of all cases between 1998 and 2002 (Crook 2003: 2). At the beginning of 2002, the number of land cases pending in the High Courts alone - and only in first instance, not on appeal - was estimated at 14964 (Kotey, Dowuona-Hammond, and Atuguba 2004: 67). In a 2003 report it was claimed that there were then about 35000 land disputes before the courts (Ministry of Lands and Forestry 2003).

36 Crook describes that in the Kumasi High Court the rate at which land cases were being settled was constantly outstripped by the rate at which new cases were being added each year, in spite of efforts of the Asantehene since 2000 to withdraw stool land cases from the courts (Crook 2003: 2).

37 Of I49 land cases documented in Ghanaian law reports between I96r and 2003, half of them took more than 4 years to be disposed of. However, $34 \%$ of the cases took less than two years (Kotey, Dowuona-Hammond, and Atuguba 2004: 90).

38 Interview farmer Besease, 22 May 2003.

39 In some instances, a court action seems a form of harassment calculated to cause the defendant expense and inconvenience (Crook 2003: 9). "If you have money you can 'outlive' the other" (Interview elder Kyidomhene, Besease, 7 May 2003).

40 According to Wood, this only happens in approximately $5 \%$ of the cases (Wood 2002: I).

4I High Court Justice Baffoe Bonny explained this in the following way: "when I strike out a case, often the lawyer will come to me the next day and if he has good reasons I have to reinstate the case. So what is the use? And I can proceed with the case without the lawyer, but then he will want to read the proceedings the next day. The handwritten notes therefore have to be typed out, which takes a long time, leading to more delay than another adjournment" (personal communication 5 September 2005).

42 In $94 \%$ of the reported cases both plaintiff and defendant were represented by lawyers (Kotey, Dowuona-Hammond, and Atuguba 2004: II3-4). In Crook's research 96.4\% of the respondents in the High Courts had employed a lawyer as compared to $36.4 \%$ of the litigants in the Magistrates Court (Crook 2003: II).

43 Besides lawyers' fees, the costs can include court fees, lost income, travel and accommodation costs, costs of bringing witnesses to court and bribes or speed money.

44 Note that Crook's data reflect the costs at various points during legal procedures, not necessarily nearing the end (Crook 2003: II).

45 In Crook's research, in Kumasi High Court a combination of Twi and English was used in $78.3 \%$ of the cases. In $13.0 \%$ only Twi was spoken, and in $8.7 \%$ only English (Crook 2003: I2-I3).

46 In Kumasi High Court, $42.5 \%$ of the respondents said they could not answer this question because they had not started their trial yet $35 \%)$ or had not understood the trial (7.5\%). Only $4.4 \%$ gave a negative answer, I. $3 \%$ a mixed answer, and 5 I.9\% a positive one (Crook 2003: I3-I4). 
47 The jurisdiction to hear and determine any matter relating to chieftaincy is placed exclusively in the hands of the Traditional Councils - consisting of the paramount chiefs and their subchiefs - and the Regional and National Houses of Chiefs (sections I5 (I), 22 (I), 23 (I) of the Chieftaincy Act I97I (Act 370); see also chapter 22 of the I992 Constitution).

48 Section II7 (I) Courts Act I993 (Act 459).

49 From a rule of law viewpoint this is a dangerous development, since it leads to the Asantehene - a very important administrator in the field of stool land - as almost the only 'judge' in this field. That again could evolve into the Asantehene as the main law-maker, when his 'decisions' would be published and taken as a leitmotiv in other disputes and administration in general. The Asantehene is currently taping all his dispute settlements, opening up the possibility of publicizing them in future (interview legal advisor of the Asantehene, 2I September 2005).

50 Even after being confronted with all the adjournments and delays, 6I.2 \% of the respondents in Kumasi High Court stated that going to court was worth all the trouble. Female litigants were the most enthusiastic of all, 70.4\% saying the case was worth it. This might be explained from a deeper dissatisfaction with the - male-biased - traditional system. Litigants in cases involving unauthorized disposition by a chief or by a stranger were less satisfied (50\%), which according to Crook suggests that in these cases delay is critical, since land once alienated is difficult to reclaim (Crook 2003: I4-I5).

5I As an illustration, of all reported cases between I96I and 2004, 69\% of all plaintiffs and $73 \%$ of all litigants were farmers (Kotey, Dowuona-Hammond, and Atuguba 2004: IIO-2).

52 These reasons explain why the rate of out-of-court settlement is extremely low in Ghana. In Kumasi High Court, of the group going straight to court $-52 \%$ of the respondents $33 \%$ specifically mentioned the authority of the court as main reason; $28.3 \%$ said to be frustrated by the lack of response of the other party or the unwillingness to reach an agreement. They therefore saw a court action as a way of using an authoritative force to get the issue resolved.

53 Of those respondents who went through other forms of dispute settlement before the court, as many as $73 \%$ said that 'enforcement' of the judgment was their main reason to turn to court (Crook 2003: 8).

54 In Crook's research $\mathrm{I} 2.8 \%$ of the land cases studied dealt with unauthorized dispositions of rights in land by chiefs or strangers (Crook 2003: 6).

55 Such as Kotey, Dowuona-Hammond, and Atuguba 2004 and Wood 2002.

56 The modern legal system of Ghana came into existence in 1876 with the passing of the Supreme Court Ordinance 1876 , which set up a Supreme Court with the power to administer all the laws of the Gold Coast, including customary law. Until I9I6 customary law had to be proved as a fact, which could be done by calling witnesses or by providing documentary evidence found in textbooks. In I9I6 the doctrine of judicial notice was accepted in Angu v. Attah ((I9I6) P.C. '74-'28, 43 (P.C.)). This decision says that customary law must be proved in first instance by calling witnesses "until the particular customs have, by frequent proof in the courts, become so notorious that the courts will take judicial notice of them". Even if customary law is the indicated law, its application may be excluded by reason of some other supervening factor. Such factors can be classed under two heads: (i) incompatibility with legislation for the time being in force in the territory; (ii) repugnancy to natural justice, equity or good conscience. See Allott I960: 7298, i94-5; Allott I970: 25 .

57 This section describes judicial customary land law in entire Ghana, not specifically in the Ashanti Region. Despite the tendency of courts to unify the various customary laws (Asante I969: I0I; Koesnoe I985: 98), certain cases have no bearing on the Ashanti situation. This section presents a selection of those cases that are most relevant for and 
comparable with the Ashanti situation. Such cases do not abound in Ghanaian case law, for which a number of explanations can be named. First the fact that in cases involving unauthorized disposition by a chief or stranger delay is critical, since land once alienated is difficult to reclaim (Crook 2003: I4-I5). The delays in the judicial system might make state courts an unattractive option for the aggrieved party. Secondly, the farmer often chooses to resist the buyer instead of the chief. This might also lead to a court case, but the buyer might also go back to the chief to claim a different plot of land. Thirdly, many people still do not feel comfortable in suing their own chief. Either because of socio-cultural inhibitions, or because of the chief's powerful position in the village.

58 The Supreme Court Law Reports 2003/4 have also been published, but I have not been able to get hold of it during my stay in Ghana.

59 For the selection of relevant cases until I986, I have benefited strongly from Woodman's elaborate analysis of customary land cases in the Ghanaian courts (Woodman I996). The Council for Law Reporting is the institution that compiles the Ghana Law Reports. All courts of superior judicature - High Courts, Court of Appeal and Supreme Court send (part of) their decisions to the Council. The author wishes to express her gratitude to the council's editor and librarian, for their generous co-operation and discussions, as well as to the interviewed lawyers, for their insights and case files.

6o Norquaye-Tetteh v. Malm [I959] G.L.R. 368, at 370-7I.

6I According to Ollennu "the word "usufruct" does not appear to be a correct legal term for this sort of estate in land because it suggests rights and attributes less than really are the case. The estate in question is both inheritable and alienable and these both negate the word "usufruct"', (Ollennu ig62: io).

62 See Thompson v. Mensah (I957) W.A.L.R. 240 (C.A.); Oblee v. Armah (I958) 3 WALR 484; Bruce v. Quarnor [I959] G.L.R. 292; Akwei v. Awuletey [I960] G.L.R. 23I.

63 See for instance Mensah v. Ghana Commercial Bank I957; Oblee v. Armah (I958) 3 WALR 484; Akwei v. Awuletey [I960] G.L.R. 23I; unreported judgment of HC Kumasi, No. 5/97 of I3 May I997. But see contra Ameoda v. Pordier ([I962] I G.L.R. 200), where it was held that any "subject has an inherent right by grant expressed or implied (...) to occupy portion of the land not already in possession of another, for the purpose of building, and living thereon, for any lawful purposes including erecting a kraal in rearing cattle, and farming”. Cf. Ollennu I962: 32, 55; Woodman I996: 90.

64 (I958) 3 W.A.L.R. 484.

65 [I963] 2 G.L.R. I.

66 [I98I] G.L.R. 300, at 310.

67 See for instance Frimpong v. Poku [I963] 2 G.L.R. I: "Permission is never refused (...)". Cf. Woodman I996: 9I, 92.

68 (I95I) D.C. (Land) '48-'5I, 3I2.

69 This court functioned as the Court of Appeal for all British colonies in West Africa from I928 until I957.

70 Golightly v. Ashrifie (I955, I4 W.A.C.A. 676) - this was the appeal case of the Kokomlemle Consolidated Cases, see note 287; Bannerman v. Bossman (Unreported judgment of WACA of 27 February I957, quoted in Ollennu I962: 56).

7I This was stated explicitly in Kotei v. Asere Stool [I96I] G.L.R. 492, at 495; and in Ollennu and Woodman I985: 60.

72 The consolidated suits W.S. Annan v. P.O. Ankrah, Unreported judgment of the Land Court delivered 27 October, I952, quoted in Ollennu I962: 56.

73 A citation repeated literally in Nyamekye v. Ansah [I989-90] 2 G.L.R. I52.

74 Thompson v. Mensah (I957) W.A.L.R. 240 (C.A.). See also Kotei v. Asere Stool [I96r] G. L.R. 492, at 495. Cf. Ollennu I962: 55. 
75 (I958) 3 W.A.L.R. 484, at 485. Cf. Atta Panyin v. Nana Asani II [I977] I G.L.R. 83, at 9I: "For customary law abhors the placing of fetters on a usufructuary title other than the obligation to provide commutable services".

76 Unreported judgment, No. 5/97 of I3 May I997.

77 Kokomlemle Consolidated Cases (I95I) D.C. (Land) '48-'5I, 3I2; Golightly v. Ashrifi (I955) I4 W.A.C.A. 676; Thompson v. Mensah (I957) W.A.L.R. 240 (C.A.); Ohimen v. Adjei (I957) 2 W.A.L.R. 275; Oblee v. Armah (I958) 3 W.A.L.R. 484; Norquaye-Tetteh v. Malm [I959] G.L.R. 368; Ameoda v. Pordier [I962] I G.L.R. 200; Total Oil Products v. Obeng [I962] I G.L.R. 228, at 237; Bressaah v. Asante [I965] G.L.R. II7 (S.C.); Mansu v. Abboye [I982-83] G.L.R. I3I3; Kwadwo v. Sono [I984-86] G.L.R. 7; Awuah v. Adututu [I987-88] 2 G.L.R. I9I; Nyamekye v. Ansah [I989-90] 2 G.L.R. I52; Unreported judgment H.C. Sekondi No. 3/92, I6 May 1995; Unreported judgment of H.C. Sekondi No. 7/92, I6 October 1995; Unreported judgment of H.C. Ho No. I/99, 3 May 2000. Cf. Woodman I996: 97, 107 .

78 [I962] I G.L.R. 228, at 237.

79 Mansu v. Abboye [I982-83] G.L.R. I313, at I3I5.

80 Ohimen v. Adjei (I957) 2 W.A.L.R. 275; Tawiah v. Gyampo (I957) 3 W.A.L.R. 293.

8I Amin v. Mensah (I9II) Ren. 636, D. \& F.C. 'ir-'i6, 4 (D.C. and F.C.), quoted in Woodman i996: 108.

82 Takyi v. Tettey (I949) D.C. (Land) '48-'5I, IoI. Woodman also mentions the case Wutoh v. Gyebi (1959), reported in Ollennu I962: I97. In this case it was implied in a passage from a Native Court judgment cited with apparent approval by the High Court, that a purchaser from a stool could dispossess the usufructuary in return for reasonable compensation. This passage, however, could be interpreted as suggesting that the consent of the usufructuary was necessary. This particular point was, however, not in issue in Wutoh $v$. Gyebi, and the judgment can therefore not provide direct authority on such a rule (Woodman i996: 108).

83 See above, especially note 294 .

84 Azuma III v. Aruna (I950) D.C. (Land) '48-'5I, 258.

85 Bruce v. Quarnor [I959] G.L.R. 292, at 298.

86 Mensah v. Amagyei [I96I] I G.L.R. 384, at 386.

87 [I962] I G.L.R. 228.

88 (I949) D.C. (Land) '48-'5I, I9I.

89 Ashiemoa v. Bani [I959] G.L.R. I30; Donkor v. Danso [I959] G.L.R. I47; Bruce v. Quarnor [I959] G.L.R. 292; Mensah v. Amagyei [I96I] I G.L.R. 384.

90 [I950] G.L.R. I30.

9I [I98I] G.L.R. 300, at 3I0.

92 Unreported judgment, No. 98/95 of I8 December I997.

93 Owiredu v. Moshie (I952) I4 W.A.C.A. II; Golightly v. Ashrifi (I955) I4 W.A.C.A. 676. Cf. Woodman I996: 102.

94 Coussey J. in the unreported judgment of the W.A.C.A., CA No. 107/49 of 15 January I952, an extract of which appears in Ollennu I962: 59. Ollennu J. also refers to this decision and quotation in his judgment in Thompson v. Mensah (I957) 3 W.A.L.R. 240 (C. A.) at 249. Cf. Woodman I996: I02.

95 Ohimen v. Adjei (I957) 2 W.A.L.R. 275; Thompson v. Mensah (I957) 3 W.A.L.R. 240 (C. A.); Baidoo v. Osei (I957) 3 W.A.L.R. 289; Donkor v. Danso [I959] G.L.R. I47; In re Public Lands (Leasehold) Ordinance [I959] G.L.R. I63; Norquaye-Tetteh v. Malm [I959] G.L. R. 368; Ameoda v. Pordier [I962] I G.L.R. 200; Total Oil Products v. Obeng [I962] I G. L.R. 228.

96 Asseh v. Anto [I96I] I G.L.R. I03 (S.C.).

97 Kotei v. Asere Stool [I96I] I G.L.R. 492, followed by Jiagge J. in Kotey v. Odoi [I962] I G.L.R. 347. 
98 Kotei v. Asere Stool [i96r] I G.L.R. 492 at 495.

99 Buor v. Bekoe [1957] 3 W.AL.R. 26 (a decision of Ollennu J.); Akwei v. Awuletey [1960] G.L.R. 23I (S.C.). See Woodman I996: I02.

I0० Ollennu's view was for instance followed in Robertson $v$. Nii Akramah II (consolidated) [I973] I G.L.R. 445; Atta Panyin v. Nana Asani II [1977] I G.L.R. 83; Awuah v. Adututu [1987-88] 2 G.L.R. I9I; Nyamekye v. Ansah [I989-90] 2 G.L.R. I52; Unreported judgment No. 59/95, I0 April 1997. Cf. Da Rocha and Lodoh I999: I8; Woodman I996:I02.

I0I Unreported judgment No. 59/95, I0 April I997. When the usufructuary rights are alienated to a stranger, proper provision needs to be made for commuting the customary services. It is the stool whose duty it is to commute the customary services, commuting is not the responsibility of the subject-transferor. The usual custom is that when a stool notices a stranger on a portion of the stool land the stool calls upon him to come for consideration of his case as to whether the stool would admit him to performance of the customary rites to the stool, or whether the stool would commute the services (Total Oil Products v. Obeng [1962]I G.L.R. 228, at 235-6).

IO2 Robertson v. Nii Akramah II (consolidated) [1973] I G.L.R. 445. The case Atta Panyin v. Nana Asani II ([1977] I G.L.R. 83) did not specify the land use of the transferred land, but since it dealt with land of a whole village, it can be assumed that this included both farmland and residential land.

I03 Nyamekye v. Ansah [1989-90] 2 G.L.R. I52. Cemetery land shares with residential land the feature of relative permanency.

I04 See e.g. Thompson v. Mensah (I957) W.A.L.R. 240 (C.A.); Ohimen v. Adjei (I957) 2 W. A.L.R. 275; Baidoo v. Osei (I957) 3 W.A.L.R. 289; In re Public Lands (Leasehold) Ordinance [1959] G.L.R. I63; Total Oil Products v. Obeng [I962]I G.L.R. 228; Mansu v. Abboye [1982-83] G.L.R. I313.

I05 Amodu Tijani v. Secretary to the Government of Southern Nigeria [I92I] 2 A.C. 399 (P. C., from Nigeria), an extract of which appears in Ollennu 19625 ; Ohimen v. Adjei (I957) 2 W.A.L.R. 275; Unreported judgment of H.C. Ho, No. I/99, 3 May 2000.

Io6 Abude v. Onano V (I946) I2 W.A.C.A. Io2; Nkonnua v. Anaafi [I96I] 2 G.L.R. 559;

107 Gyamfi v. Owusu, C.A. I6thApr. 1982 [198I] GLRD 57 at I67.

I08 (I982-85) I6 University of Ghana Law Journal I67, at I68.

I09 (I982-85) I6 University of Ghana Law Journal I67, at I7I. The following are the criteria as set out in the headnote in Kwan $v$. Nyieni: "(I) as a general rule the head of family, as representative of the family, is the proper person to institute a suit for recovery of family land; (2) to this general rule there are exceptions in certain special circumstances, such as: (i) where family property is in danger of being lost to the family, and it is shown that the head, either out of personal interest or otherwise, will not make a move to save or preserve it; or (ii) where, owing to a division in the family, the head and some of the principal members will not take any steps; or (iii) where the head and the principal members are deliberately disposing of the family property in their personal interest, to the detriment of the family as a whole. In any such circumstances the Courts will entertain an action by any member of the family, either upon proof that he has been authorized by other members of the family to sue, or upon proof of necessity, provided that the Court is satisfied that the action is instituted in order to preserve the family character of the property."

IIO (1982-85) I6 University of Ghana Law Journal I67, at I7I-3.

III Id.: I73.

II2 Owusu v. Agyei [I99I] 2 G.L.R. 493.

II3 Id.: 497 .

II4 Id.: 506 .

II5 Contrary to family property, where the Head of family (Accountability) Law, I985 (PNDCL II4) allows the head of family to be sued for an account. 
II6 This information is based on extensive interviews with and a survey held among inhabitants of nine villages in peri-urban Kumasi. It is also supported by evidence from other areas of Ghana, see the literature mentioned above, note $22 \mathrm{I}$.

II7 Unreported judgment, no. 5/97 of I3 May I997.

II8 Owusu v. Agyei [I99I] 2 G.L.R. 493, at 506. Although this statutory imperative exists for all 'stool land revenues', the chiefs continue to call the purchase price of land 'customary drinks', and claim that it therefore should not be regarded as 'stool land revenue' in the sense of the Office of the Administrator of Stool Lands Act 1994, Act 48I (See Ubink 2008, forthcoming).

II9 Personal communication, 5 September 2003.

I20 Chanock severely criticizes the tendency to: "use custom and customary law as expressive of a long-lived and homogeneous value system which represented what people actually did. (...) It is important to remember that custom is not simply what people do; that it is a set of values expressive not simply of communal life, but of a way of maintaining order and relations of power. (...) Which patterns of behavior are put forward as representative of custom is (...) a matter of current politics (Chanock I989: 173-4, I85).

I2I Interview researcher KNUST, 30 July 2003.

I22 Article II (3) of the I992 Constitution

I23 Personal communication, 5 September 2003.

I24 In certain cases a court may consider it justifiable to question the reliability of the evidence on which the first decision was based, and look to fresh evidence. Where past decisions do not establish the customary law on a point beyond possibility of doubt, it is necessary to rely in addition on other types of evidence. These are, in descending order of reliability, texts recognized as authoritative by the courts, past decisions of native courts, all other accounts of native practice. And, of course, if precedent is lacking it is necessary to seek sociological evidence (Woodman I996: 37-48).

I25 Another difference is that whereas changes in local customary law are induced by the society, changes in judicial customary case law will necessarily be judge driven, and might therefore take a different direction from changes in local customary law.

I26 According to Koesnoe, “(w)hen the English common law was getting similarly fossilized by reason inter alia of the doctrine of stare decisis, the rules of equity developed to mitigate the rigors of the common law. There has been no corresponding development in the customary law in Africa" (Koesnoe i985: 99).

I27 Other state institutions also cling to the fiction of uniformity of customary law. For instance the Lands Commission has been directing land buyers in the Upper West Region to the local chief, whereas in that area land ownership is separated from chieftaincy and lies with the tendamba, the earth priest (interview researcher KNUST, 30 July 2003).

I2 8 Doctrines of state law pose that courts are bound not to adopt as customary law any rule or principle which is contrary to statute or overriding policy - comparable to the 'repugnancy clause' of the colonial period, which read that courts were bound not to apply any rule which in its opinion was "repugnant to natural justice, equity and good conscience" (Ekow Daniels I99I-2: 74-5; Koesnoe I985: 98).

I29 For these attempts the same doctrines can be used as in the preceding footnote.

I30 As said before, due to a lack of literature, this chapter does not discuss the execution of court decisions in Ghana.

I3I "Chiefs coat their actions in custom" (interview OASL Kumasi, 27 June 2003). Dr Adinkrah, a legal scholar and a chief himself, calls this "the prostitution of customary law by the chief” (Interview Dr Adinkrah, 4 September 2003).

I32 Interview member Plot Allocation Committee Besease, 29 May 2003.

I33 Interview elder Kyidomhene, 7 May 2003.

I34 Mnookin and Kornhauser I979. Especially the media and NGOs could play a significant role in awareness creation. Whereas there are hardly any local NGOs working on land 
matters in Ghana, the media are to a certain extent already involved. For instance the Kumasi based radio station Capital Radio broadcasts a weekly show on land matters and newspapers regularly comment on court cases.

I35 See a.o. Daily Graphic 25 August 2003: 3; Ghanaian Times 5 August 2003: I, 25 August 2003: 3 .

I36 Interview District Assembly Ejisu, I2 January 2004. Chiefs are said to be especially influential in the Ashanti Region with its hierarchical chiefly structure with the Asantehene at the top.

I37 Due to article 276 (I) of the I992 Constitution chiefs are not allowed to take part in active party politics. Any chief who wishes to do so and seek election to Parliament has to abdicate his stool. The second clause of this section does however permit a chief to be appointed to any public office for which he is otherwise qualified.

I3 8 See for a more elaborate discussion of the functioning of these state institutions Ubink and Quan 2008, in press.

I39 In many areas chiefs have even drawn up their own unofficial planning schemes without involving the District Assembly.

I40 As said above, this is another way to denote the usufructuary interest.

I4I The ratio decidendi of this case was that 'family lands' are not subject to the administrative regulations that the Lands Commission imposes on 'stool lands', nor are they caught by article 167 (5) of the 1992 Constitution.

I4 2 He deducts this from a number of factors. First, he implies that the rationale behind the article was to assure some intergenerational equity, through the prohibition of permanent alienation and resultant loss of stool lands in a manner detrimental to the future generations of the stool subjects. The grant or existence of the customary freehold is in no way inconsistent with this policy objective. Secondly, the operative part of article 267 (5) is "shall be created". This does not apply to the subject of the land-owning stool, because the subject's entitlement to a customary freehold is inherent and not based on an act of creation. Thirdly, article 267 (5) starts with the words "subject to the provisions of this Constitution", which makes provision to read and construe the article in the light of other provisions of the Constitution. The article should therefore be read and interpreted in the light of article 267 (I), which provides: "All stool lands in Ghana shall vest in the appropriate stool on behalf of, and in trust for the subjects of the stool in accordance with customary law and usage" (emphasis added). One of the most important customary laws is that the subject of a stool is entitled as of right to a portion of vacant stool land and upon such occupation the member acquires the customary freehold. It is most illogical to fathom an interpretation of article 267 (5) which takes away this time-honored customary principle. Had the Constitution sought to make such a radical departure from an age-old custom and practice, the Constitution would have clearly done so categorically, clearly and unambiguously. 



\section{Conclusion: Stool Land Management and the Quest for Customary Law}

Janine M. Ubink 



\section{Conclusion: stool land management and the quest for customary law}

\section{Introduction}

To analyze the functioning of customary law and traditional rule, this book describes the management of stool land in peri-urban Kumasi. The findings presented here, however, hold relevance beyond Kumasi or Ghana. Throughout the book, literature on other countries in Africa and occasionally other continents has been studied, both to analyze the research material at hand, and to draw conclusions from the data. Many countries, especially within sub-Saharan Africa, but also outside, are faced with similar issues of commodification of land, weak governments, increasing inequity in customary land management, and the role of traditional authorities therein. The conclusions and recommendations therefore have a relevance outside Ghana. Furthermore, the approach of this research provides insights for legal anthropology, with regard to the field study of customary law and the official interpretation and ascertainment of customary norms and rules. These issues - with which I was confronted during my fieldwork and for which answers were not sufficiently provided in existing literature - are central for legal anthropologists, working with concepts such as legal pluralism and living law (Ehrlich I936; Moore I973). This concluding chapter starts with an outline of the main findings of the earlier chapters on customary stool land management, traditional rule, land policy, state and donor involvement, and court decisions. It then turns to a discussion of more general insights regarding the study, application, and interpretation of customary law, before it concludes with a preview of possible actions to enhance tenure security in peri-urban Kumasi and other parts of Ghana.

\section{Stool land management in peri-urban Kumasi}

\section{Shattering the Myth of Equality}

We have seen in this book that peri-urban Kumasi currently witnesses a growing demand for residential land, triggered by factors such as population growth, urban expansion, and remittances by Ghanaians liv- 
ing abroad. Especially in the outskirt villages along the major roads from and to Kumasi, this demand is high, and farmland which is being cultivated by community members is rapidly being converted to residential land and being leased or 'sold' mainly ${ }^{\mathrm{I}}$ to outsiders. This process of monetization of land has led to severe debates and struggles revolving around the question of which actors should be involved in the decision making and the execution of the conversion and lease of land to strangers, and the question of revenue division amongst farmers, families, traditional authorities, and the community as a whole. ${ }^{2}$

Gains largely depend upon the opportunity or ability to initiate sales, since the undoing of established transactions is often very difficult. In some villages farmers were able to sell their farmland, but in most villages chiefs utilized their position as custodian of the land to become the prime actors in selling land. In many indigenous tenure systems a traditional leader who administers land is viewed as holding a tenure in that land, and sometimes the traditional leader is able to convert his 'administrative estate' to a personal right (Bruce I988: 42). This strong customary position of the chiefs is enhanced by the system of land use planning, in which local government supports the chiefs' administrative tools to allocate land, such as their capacity to draw up planning schemes and demarcate village farmland into residential plots.

Farmers and families who had been working on the land for generations, lost their farmland and with it their livelihood. When sales led to disputes between chief and farmer, the position of buyers was also liable to suffer. They lost part of the allocated land, were threatened or assaulted by the aggrieved party, or were asked to pay an additional sum for the land or for the signing of papers. Sales of residential land have thus disproportionately benefited the traditional elite at the cost of small-scale farmers and stranger buyers. Customary tenure in peri-urban Kumasi does not constitute a guarantee of security for the poor. The general trends described in peri-urban Kumasi are confirmed by mounting evidence from other parts of Africa and beyond that the processes of commodification of land - whether due to urbanization, immigration, population growth, possibilities for logging and mining, or high quality agricultural land - are restricting access to land for the poor, increasing the appropriation of land by influential elites, and exacerbating socio-economic inequalities. In these cases also, the winners are often found among chiefs, elders, and heads of families. ${ }^{3}$ Since local communities are sites of inequalities, measures to strengthen customary institutions, and local control to access to land without regulating checks and balances on local power holders, may actually reinforce inequality.

A number of authors impute the increased inequality under customary tenure to the differentiated bargaining positions within a commu- 
nity and the limits of negotiability and ambiguity. ${ }^{4}$ Although the data from peri-urban Kumasi endorse both these aspects, too much emphasis on negotiability results in an overestimation of people's agency, and the image of relatively open, negotiable, and adaptive customary systems of land tenure obscures the processes of exclusion and class formation. A description of struggles and debates in Besease has shown that local land contestations range from negotiations in which parties have more or less equal power, and negotiations within highly unbalanced power relations, to unilateral actions in which one party is presented with a fait accompli regarding an alteration in rights but where resistance may succeed in changing the outcome to a certain extent, to unilateral actions in which acts of resistance remain ineffective and the strongest party imposes a new constellation of rights or even negates all rights of the weaker party. ${ }^{5}$ The tendency to call all local dealings with land 'negotiations' is not only incorrect but also dangerous, as it obscures the stratification of the local communities in which these processes take place, overemphasizing the positive aspects of customary tenure, while neglecting its injustices. This sends a wrong signal to policy makers who are currently revaluating customary tenure systems yet often still lack an eye for issues of social differentiation and equality. Overemphasizing the negotiability of customary tenure will sustain the gap between empirical realities of customary land tenure and its characterization in policy debates.

\section{Customary Law and Power}

Although many of the chiefs' current practices in the research area are diametrically opposed to descriptions of customary law in authoritative literature, case law, and articles of the Ghanaian Constitution, the chiefs still claim to act according to customary law, but a different kind of customary law. Some chiefs claim that the customary rules protecting usufructuary rights in farmland are outdated and need to be adjusted to modern circumstances. Communal land that can be used in a more productive way should therefore, in their opinion, be brought back into chiefly administration. Other chiefs even fully deny the existence of any rights of indigenous (non-royal) community members in stool land. They claim that land belongs to the royal family who had only given land out for farming purposes to temporary caretakers, who have no inherent right to this land. The chiefs thus can reclaim it at any time, without paying compensation. ${ }^{6}$

Many farmers were highly critical about the land conversions by traditional authorities and they have tried to confront their leaders and change their behavior. This was done in various fora ranging from public village meetings to private consultations; communicated by locals or 
influential outsiders; and termed in deferential pleas or vehement demands, sometimes even pressed home by acts of violence. Often local members of the District Assembly and the Unit Committee were central figures in the resistance against mismanaging chiefs. The effectiveness of these actions depended on many factors, not least on the personality of the chief involved and the power configuration of the local arena. In general, however, chiefly accountability was low and local checks and balances feeble. The two main traditional checks on chiefly functioning, i.e., ruling in council with the elders and the option to destool a seriously malfunctioning chief, were no longer very effective. Even development-oriented chiefs who were spending most land revenue, and sometimes even their own funds, on community development were not overly taken with the idea of accounting for their land management to the people. Neither were they inclined to reproach other chiefs for their land administration.?

On account of the prominence of customary law in the field of land administration, all actors in land struggles have to legitimize their actions and claims largely with appeals to customary law. ${ }^{8}$ When circumstances change and new opportunities arise, they will try to use the unwritten and somewhat pliable nature of customary law to construct norms in their own interests. Struggles over land will thus often take the form of interpretative struggles over meaning in which "the power to name" can be a highly political issue (Bassett I993: 2I; Shipton and Goheen I992: 309-3II). The critical question is which actor or group of actors has the power to issue definitions and is able to mobilize support - from community members, the traditional system, and the state - for its version of customary law. Since chiefs are generally regarded as authorities in the field of customary law and as guardians of stool land, they are able to point to custom to acquire and legitimate power over land in the local arena and to resist interference by the state. Customary law thus seems not to constrain the conduct of chiefs with regard to land management and is perhaps, to speak with Mamdani, "not about limiting but rather enabling the power of local native authorities" (Mamdani I996: I09-I0). According to Berge, customary law's lack of strong defenses of individual rights in a modern society with land scarcity does not come as a surprise, as the rules on land tenure were fashioned in a society where there was abundant land (Berge 2006: I6). Where customary rules originally strongly linked the ability to exercise a right with the fulfillment of obligations (Odgaard 2003: 83), chiefs are currently trying to separate the two, claiming the right to administer land while neglecting the duty to use it in the best interest of the community (cf. Mtengeti-Mgiro I99I). 


\section{A Policy of Non-interference}

Over the years, consecutive governments have taken piecemeal measures in the area of land use planning, land title registration, issuance of formally registered leases, and stool land revenue collection. We have seen that the principal agencies involved in this field, despite their mandate, in practice do not check customary land management by traditional authorities. The Office of the Administrator of Stool Lands, The Lands Commission and the District Assembly hardly have any influence at village level, and local members of the District Assembly and Unit Committee, who often do play an important role in local debates and struggles for land and revenue, are not backed up by their superiors at the district level. The failure of these state institutions to control stool land management is due to a combination of factors: a lack of chiefly co-operation; limited challenging of the chiefs by Land Sector Agency (LSA) officials; lack of political support for challenging actions; LSAs' lack of funds, staff, and material; and their problems of mismanagement and corruption. The lack of political support constitutes a 'policy of non-interference' with regard to matters involving chiefs. ${ }^{9}$

This policy - that should be seen as a deliberate course of the government (cf. Moore I986: 320) - can be explained by the political power of chiefs and their close alliances with regional and national political elites. The political party of the current president, the NPP, is particularly closely connected to chiefs. The lack of political backing is justified in state discourse, which continuously emphasizes the sacrosanctity of customary land management and chiefly rule in general, as well as the ability of locals to solve their problems within the traditional system. Despite frequent indications that local checks and balances such as ruling in council and destoolment actions are often not very effective, the government continues to refer to "the morality of the local space" (Khadiagala 200I: 59) to disclaim the need for external interference. Such state discourse and the government's 'policy of non-interference' gives chiefs little reason to fear state intervention in land matters. Moreover, the position of chiefs is even enhanced by the state, through its tendency to formalize the chiefs' role in local land use planning. A clear example is that the District Assembly will only issue a building permit when the allocation paper carries the signature of the (or a) chief. ${ }^{\mathrm{I}}{ }^{\circ}$

In I999 the government of Ghana, after decades of piecemeal legislative and state management measures, formulated its first comprehensive National Land Policy. This was followed in 2003 by a heavily donor sponsored Land Administration Project (LAP), which included the plan that the government should divest itself of responsibility for the man- 
agement of stool lands, to be transferred to Customary Land Secretariats (CLSs) under the aegis of traditional authorities. The policy of noninterference also influences the execution of the CLS component of the LAP. The implementation of this component in the first years suggests that the government is reluctant to openly debate, let alone restrict or control, chiefs' functioning, which entails a significant risk that government will not commit fully to the proclaimed goals of enhancing equity and accountability in customary land management arrangements. The above shows that the LAP's starting point that LSAs do not function effectively is justified. Nevertheless, the empowerment of chiefs through the resourcing of CLSs, without enhancing accountability mechanisms and effective checks and balances, brings a considerable risk that powerful customary leaders may utilize CLSs to consolidate their political control over land, with negative consequences for poorer, less powerful land users. Although there are isolated cases of spontaneous good practice (such as Gbawe), and some chiefs express goodwill towards CLSs, land holding community members and other land users currently lack forms of organization capable of counterbalancing the power of chieftaincy. In peri-urban areas chiefs can be expected to try to utilize their new power to convert farmland to residential land and pocket the bulk of the revenue. ${ }^{\text {II }}$

The LAP teaches some valuable lessons with regard to stately interventions in the customary legal sector. Strengthening customary tenure systems should be informed by thorough knowledge of the functioning of customary systems and go hand in hand with a full consideration of equity in such interventions. Designing the governance arrangement for sound customary land management institutions, and determining how different stakeholders will be empowered and their interests represented, presents considerable challenges. Implementation requires strong political will from the side of the government, combined with perseverance from the donors involved. Simply subsidizing traditional authorities with material and technical support and hoping for the best will not provide the basis of a sustainable approach.

\section{Access to Justice through State Courts?}

The above shows that the interventions of the Ghanaian government have not led to an improvement of tenure security for peri-urban farmers. The example of the CLSs shows that governmental policy might even enhance the position of the chief at the expense of the farmer. This book poses the question of whether Ghanaian courts can and do protect the interests of peri-urban farmers. An analysis of published and unpublished court cases shows that courts have decided firstly that the usufructuary rights of indigenous farmers are quite secure and can 
in principle not be taken away by the chief. Secondly, the farmer does not need the consent of the chief as allodial title holder to transfer his/ her rights in land. This seems to apply even when farmland is transferred for non-farm purposes, such as housing or cemetery plots. And even if an express grant of the chief were needed to change land use from agricultural to residential, as was stated in one court case, ${ }^{\mathrm{I2}}$ it seems that the community member has a right to receive this grant unless overriding communal interests prohibit it. Thirdly, chiefs can be held accountable for the way they use stool land revenues, since there is a "statutory imperative that moneys from stool land acquisitions should be lodged in a designated fund." All in all, courts seem to protect the interests of the individual usufructuary against the chiefs' attempts to re-appropriate stool lands for residential purposes. There is a trend in judicial customary law, however, towards giving more power to the chief in his capacity of administrator, with the goal of ensuring sound town planning and more equal distribution of land through the instrument of express grants. Considering the above, this trend cannot be interpreted to mean that the chief has the power to deal with land as he pleases, without regard for community interests or compensation for farmers. ${ }^{\mathrm{I3}}$

Hotly debated issues in Africa and beyond centre around access to courts and the effects of court decisions on local reality. In Ghana, notwithstanding the high number of land cases in the courts, many more land disputes never reach the courts, either because of lack of access or interest of the aggrieved parties, or because they are embedded in 'chieftaincy affairs' for which state courts have no jurisdiction (section I5, Chieftaincy Act, I97I (Act 370)). This is especially true in cases dealing with chiefs' appropriation of peri-urban farmland for development purposes, which are only sporadically dealt with in state courts. Furthermore, court decisions do not seem to have much effect on local negotiations and struggles for land outside the scope of the decided cases, due to a number of reasons. Firstly, knowledge of state law and court decisions is extremely limited in the localities. Secondly, local chiefs are hardly constrained by traditional checks and balances and are barely controlled by the government and therefore feel little pressure to comply with the rules of customary law, as set out by the courts, that protect the interests of the usufructuary. ${ }^{\text {I4 }}$

\section{Traditional Authorities and Their Local Legitimacy}

Policy makers often claim the local legitimacy of chiefs as the rationale for their pro-customary land policies. This coincides with a renewed policy interest in chieftaincy. A large number of African countries has been enhancing or formalizing the position of their chiefs since the 
I990s. In the literature the resurgence of chieftaincy is often explained by either pointing to how international trends of multi-party democracy, decentralization, liberalization policies, and structural adjustment have opened up new public spaces for traditional leaders, on which they have aptly and skillfully capitalized, or by pointing to the functions performed - successfully in the authors' opinion - by chiefs. Both explanations pay hardly any attention to how people feel about chiefs, the way they rule, and the institution of chieftaincy. Chieftaincy literature in general hardly provides any data on people's perceptions. This is reflected in the fact that national and international policies on chieftaincy often do not seem to take into account people's perceptions.

Chapter 5 discusses popular perceptions in peri-urban Kumasi in a number of fields, structured around the main functions of the chief as listed by the people. The chiefs' land conversions with their severe effects on the livelihoods of the people, have received strong criticism by the villagers. In the survey, $43.9 \%$ of the interviewees outright rejected the claim that chiefs can allocate farmland to strangers for residential purposes. ${ }^{15}$ Of the $56.1 \%$ that did accept this claim, many criticized harshly the scale of land conversions, the decision-making process, and the division of revenue. This brought forth the question of how and to what extent the chiefs' dealings with land affect people's views on other tasks and activities of chiefs and their attitude towards chiefs and chieftaincy in general. Although chiefs are often said to be seen by local people as lines to civil authority, in peri-urban Kumasi the chief was regarded as only the third or fourth most appropriate actor in the field of local development projects, behind the Unit Committee and the local assembly member. The field of law and order showed a stronger but ambiguous role for chiefs. Whereas village chiefs are considered the most trusted persons for resolving a dispute, ${ }^{\mathrm{I} 6}$ chiefs account for only a minority of dispute settlement institutions resorted to ${ }^{17}$ and the continuing conflict over the role which chiefs play in the appropriation of village lands for sale as urban plots affects their ability to judge local land cases (cf. Crook et al. 2005: 74-5). With regard to the field of traditional religion the data showed that most people surveyed were Christians and Muslims. Although this most likely impacts negatively on their faith allegiance to the stool, it does not imply a total rejection of all aspects of traditional religion, and the role of chiefs in its performance.

The survey data showed that the assessment of village chiefs is correlated to their 'style' of land management. But despite very negative judgments on chiefly performance in that area, chiefs' overall performance assessments are not overly negative but range from slightly less than average to good. We have seen that this cannot be attributed to the performance of chiefs in other fields, and that in order to explain 
we need to make a distinction between the person of the chief and the institution of chieftaincy. The survey data display that people's opinion about chieftaincy hardly depends on the performance of current village chiefs. Rather, it seems that the institution of chieftaincy carries weight in and contributes to the assessment of individual chiefs. In peri-urban Kumasi dissatisfaction with local land administration and anger towards a particular chief hardly seem to lead to discussions of the desirability of the institution of chieftaincy. For the majority, chieftaincy is a fact. It is almost unthinkable for a village not to have a chief, for who will represent the community at traditional and cultural festivals, and at the Asantehene's palace? As said, the institution should be distinguished from the person on the stool. For it is not uncommon for villagers to evaluate and openly disapprove of the performance of their chief. In peri-urban Kumasi the support for chieftaincy is thus not based on high satisfaction with the way chiefs perform their tasks. Reasons are rather found in the realms of culture and identity.

This is an important lesson for African governments and international policy makers, since it demonstrates that people's support for the institution of chieftaincy does not necessarily go hand in hand with satisfaction with chiefly performance. People can simultaneously support the institution of chieftaincy and be highly critical of the performance of certain chiefs or certain tasks. Whereas governments' moves towards more formal recognition of chieftaincy are sensible in countries where chieftaincy is regarded as a naturalness by most people, this should not lead to unquestioning acceptance of the way chiefs perform all their functions. Policy makers should critically assess chiefly rule - and popular perceptions of it - in various fields, taking into account the performance of other actors in these fields, including local government representatives. Based on such assessments, governments should determine the desirability to recognize, formalize or enhance, in a ceremonial or more material form, the various functions of the chiefs. And if necessary they should place checks and balances on the functioning of chiefs in general and regulate or control certain fields in particular.

\section{Default Policy}

As said earlier, the events in peri-urban Kumasi do not stand alone. Many other areas in Africa with a high pressure on land show a severely reduced security of customary tenure, with often a negative role for chiefs, elders, and heads of families. In these cases often one or more of the above-mentioned explaining factors are found: traditional checks and balances have been more or less eroded; the state gives free rein to chiefs, elders and heads of families; and these traditional autho- 
rities can manipulate the unwritten and somewhat negotiable nature of customary law to serve their own interests. ${ }^{\text {I8 }}$ In the face of land competition and the lack of both traditional and state checks and balances, the negotiability and ambiguity of customary law mainly serve certain privileged classes and increase inequity. And this is not a new process either. Similar events have been described since the colonial period. The large amount of available literature allows us to conclude that, when the economy rapidly changes and land becomes a high-priced commodity, customary systems are often unable to evolve equitably and the tenure position of local farmers is increasingly precarious.

Despite this crisis in customary land administration, at present the policy pendulum is swinging towards a more positive view of customary tenure systems. A return to the local arena as the place of action matches with the democracy and decentralization discourses, and with structural adjustment policies that argue for a smaller state, cuts in public expenditure, and the strengthening of civil society. This trend seems to a large extent inspired by the practical necessity of starting from existing systems and by default reasoning: disappointment with state programs of titling and registration - fed by mainly economic research on the negative effects and the lack of positive results of such programs - turned the attention of policy makers towards customary tenure systems. A positive stance towards customary tenure systems should, however, not be born out of weariness with the alternatives. Neither should it be based on idealized notions of customary law - often brought forth by traditional authorities themselves - or stem from research in areas with abundant land only. Not everything customary is by definition good. Concerns of equity and power have to be brought back into the discussion. Policy responses and strategies need to be differentiated, based on analyses of whether certain communities do or do not possess the characteristics and institutions to manage their land effectively and equitably. If the communities are capable of self-regulation, the recognition of local arrangements in land policies will suffice. If, however, certain groups or actors experience serious negative consequences for their livelihoods, land policy should not give free rein to local leaders, but voice its concern with local developments and seriously consider a more or less far-reaching governmental intervention.

\section{The quest for customary law}

One of the recurring issues in this research is the existence of various claims as to what are the valid rules of customary law. This book shows that at present there is no consensus in peri-urban Kumasi on the customary norms and rules regulating the conversion and allocation of 
farmland for residential purposes. With a broad brush three main rules can be painted. Some people claim that it is farmers or families, who have had secure use rights in the land for generations, who can decide to convert and sell their farmland, with a marginal administrative role for the chiefs for the sake of land use planning and central management. Chiefs thus have no right to alienate farmland. Others claim that this power does lie with the chiefs, as they are in the best position to take care of communal matters, with the implicit or explicit condition that the chief should act in the best interest of the community. This set-up requires a well-functioning system of accountability, with destoolment as the ultimate sanction. Still others claim that chiefs have this power because they are the leaders and the owners of the land, and can therefore use it any way they please, although they are mostly considered to be under the moral but unenforceable obligation to take care of communal interests. Not only between but also within these three groups varying answers can be found regarding questions such as: Does a chief need prior consent of a farmer to sell? Does a farmer need prior consent of the chief to sell? On what grounds can consent be denied? How should the revenue be divided over farmer, chief, and community?

The above raises the question of how an investigator looking for the customary norm on allocation of residential land should go about his or her quest to "distinguish the real law from that which merely was claimed to be law" (Tamanaha I997: I02); or should he abandon any such attempt as futile (Von Benda-Beckmann i984a: 30)? Most legal anthropologists share an orientation to the observation of patterns of actual behavior. For some scholars, such as Malinowski (1926), Ehrlich (1936), Galanter (I98I) and Moore (I978), the relevant behavior was that of people within the community or social group; whereas for others, including Hoebel (1954) and Bohannan (I967), the relevant behavior was that of the disputing actors or institutions themselves (Tamanaha I997: IOI). The first category focused on regularized conduct or actual patterns of behavior; the second on dispute processing. Both methodologies offer difficulties for the study of customary norms regarding residential land in peri-urban Kumasi. Disputes over residential land in peri-urban Kumasi are not often dealt with in local dispute institutions, generally regarded as the main arena for the study of dispute processing, because those who would be supposed to adjudicate, the chiefs, were a party in most disputes. The study of regularized conduct or patterns of behavior also runs into difficulties, since practices in peri-urban Kumasi show as much variation as the normative statements by the various actors. Peri-urban Kumasi also does not show much of Holleman's "supported" forms of law observance and of "preventive law care", where legal transactions "take place in the presence 
of the local authority, family heads or interested others who are in a position, if necessary, to challenge their execution" (Holleman I973: 5934). Holleman's term 'troubleless cases' seems anyhow misplaced in peri-urban Kumasi.

"Direct observation of the rules of custom as they function in actual life" (Malinowski I926: I25) thus is a complicated activity in circumstances of change, conflict and imposition, when customary norms are contested and the rights and duties of chiefs are part of the debate (cf. Chanock I998: I7). Traditional authorities are then excluded as possible dispute settlers or authoritative presences at legal transactions. When few legal transactions are 'troubleless', all that can readily be studied are instances of struggles and negotiations. Outcomes of these contestations are determined by the various resources at the disposal of the parties, of which customary norms are only one. To further complicate things, these norms are often not explicitly referred to and, as said earlier, ideas about them will differ between various groups (cf. Chanock I989; Chanock I998). An anthropological description of customary law in peri-urban Kumasi thus shows that there are various customary norms, both in statements and in practice, regarding the allocation of residential land and that not one customary rule has crystallized as generally acceptable.

Whereas researchers can spend a considerable period of time in the field to come to a real description of customary normative systems in all their complexity, emphasizing the fluidity and negotiability of customary norms, and concluding that no certain rules can be ascertained from this exercise, both the amount of time invested and the conclusion reached are luxuries officials cannot afford. First, the methodology of scholars studying local customary law is simply impracticable for officials. In line with Palmer, it has to be acknowledged that prescriptions about method must carefully distinguish the principal user groups "for the complex methods of scholars may be unworkable in the practical world where investigations must be cost-justified" (Palmer 2004: I). Second, judges instructed to decide cases on the basis of "the rules of law which by custom are applicable to customary communities" "I9 do not have the option to "shift the analytical focus from rules and outcomes to on-going negotiation and debate” (Berry I997: 1229). And the new paradigm in national and international natural resource policy circles, i.e., to build on customary norm systems and local regulation, equally demands from African legislators and policy makers some broad formulation of customary norms and rules. Whereas Von Benda-Beckmann rightly criticizes the search for "the" customary law as a futile venture, an idea that "can only come up in the confinement of legalistic doctrines" (Von Benda-Beckmann i984a: 30), officials are expected to either apply the local customary rule or select and apply 
one of the existing rules (cf. Seidman I983-4), a choice that will determine which parties will effectively have certain rights. In the latter situation, a gap between official customary law (which has selected one rule) and local practice (following varying rules) is inevitable and has to be accepted, at least if we want customary law to enter the state realm. ${ }^{20}$ The divergence can and should, however, be kept to a minimum by making sure that the official rule is in keeping with the wider customary normative framework. The next section discusses the possibility of finding normative benchmarks to guide the selection of customary rules.

\section{Normative Bench-marks}

Many countries that have declared customary law applicable have not defined what they mean by customary law. Others have provided a definition - article II (3) of the Ghanaian Constitution for instance states that customary law consists of "the rules of law which by custom are applicable to particular communities" - but their definitions do not "in any way describe any phenomenon of any kind" (Mensa-Bonsu 20024: 3). However, for rules to qualify as customary law, it is generally accepted that they "must spring from the practices of a particular ethnic community" (id.). But which practices constitute customary law? The literature is not fully congruent on this topic but displays two often recurring requirements: repetition of facts (usus) and a normative moment (opinio necessitatis) (Allott I970: I47 and Allott I977: II; Elias I958; Franken I995: II7-8; Hogue I906; Mensa-Bonsu 2002-4: 4-6; Okany I985: 39; Walker i980: 328; Weber i967: 65-7).

Usus exists when a fixed line of behavior is followed by a more or less constant group of persons for a certain period. This raises the dilemma of how long certain practices need to be repeated to be able to speak of usus. ${ }^{2 \mathrm{I}}$ When very little time is needed to establish usus, change becomes an intrinsic feature of customary law. This not only creates problems for examining processes of change as a product of struggle between different social forces (Amanor 200ı: I6), but it would also mean that any substantial group, by diverging from a customary rule, can abolish the rule and create a new one. This would make it impossible to evaluate whether changed behavior of a majority group is right or legal according to customary law. This would in fact deny customary law any normative character. On the other hand, when the establishment of usus requires long periods of repetition adaptations of customary norms to changing circumstances becomes difficult.

The second requirement, opinio necessitatis, holds that a custom, in order to be law, must be commonly believed to be obligatory (Hogue 
I906: 197; Llewellyn and Hoebel I941: 283-4; Walker I980: 328; Weber I967: 65-7). Allott, writing on African law, speaks of rules of behavior that are not only followed as a matter of practice, but must be followed as a matter of law (Allott 1970: 147; cf. Elias I958; Okany 1985: 39).

Can these two requirements be helpful for determining the rules of customary law in peri-urban Kumasi? We have seen that there is no usus or fixed line of behavior in peri-urban Kumasi with regard to the conversion and allocation of residential land. Throughout history, however, there has been usus with regard to the security of indigenous farmers' usufructuary rights. The literature tells ample stories of chiefs profiting from customary land, but rarely at the expense of the customary freehold of indigenous community members. They tell, for instance, of chiefs selling unused land at the expense of expansion of land by current farmers and future generations, with much of the profits flowing to the chiefs; of chiefs posing conditions such as fees and tribute systems on the use of land for market crop production; and of chiefs reclaiming land sold to foreigners (Berry 1997; Firmin-Sellers I995; Fred-Mensah 2000). ${ }^{22}$ While these actions can have serious consequences for indigenous and stranger farmers, mostly they do not tamper with the customary freehold itself. In this regard, a rule that a chief can at his own discretion at any moment decide to terminate a customary freehold and sell the land in question, does not square with the historical usus of secure customary freeholds. Such a rule would rather be in keeping with a strongly feudal system where chiefs can rule arbitrarily.

With regard to the conversion and allocation of residential land there is no opinio necessitatis in peri-urban Kumasi. Customary land management in general, however, seems to be based on the shared opinion that a chief should act in the interest of his community. We can find this norm in various written sources, such as the Constitution, ${ }^{23}$ case law, ${ }^{24}$ and certain literature including that by writers closely related to chiefs. ${ }^{25}$ This norm is also often prevalent in local discourse, not in the least by chiefs and elders themselves, who use it as legitimation of their power. ${ }^{26}$ Their reference to this norm of course does not mean that chiefs always comply with it. ${ }^{27}$ The ideal system of traditional checks and balances with its possibility to destool malfunctioning chiefs also underpins a general norm that chiefs should act in the communal interest. Also here, however, we have seen that practice sometimes differs from the norm. Nevertheless, it seems to be widely believed that chiefs are obliged to act in the best interest of their community.

The selection of customary rules by functionaries such as judges, dispute settlers, policy makers and lawmakers in situations where local practices differ should not imply free choice based on the personal pre- 
ferences of the functionaries or on political considerations of how to structure and control the local. They need to be informed by usus and opinio necessitatis with regard to related issues, as new rules are pathdependent and not isolated from the wider customary normative framework. Judges are under the explicit obligation to do so as they are told to adjudicate on the basis of customary law, but also legislators and policy makers who try to build on existing local norms cannot freely choose between the various practices without regard for the wider customary normative framework. This is especially relevant in view of the current trend in national and international land policy to start from 'existing realities and systems.' To make this more concrete, let us link the somewhat abstract theoretical discussion to the three broad rules currently found in peri-urban Kumasi on the issue of land conversions, as described above. These rules vary from much (I) to some (2) to little (3) recognition of the interests of the indigenous farmers. The third rule, placing full unrestrained power in the hands of the chiefs, clearly violates the earlier usus of secure customary freeholds and the opinio necessitatis that chiefs act in the interest of their communities. This rule tries to form new customary law contrary to the timehonored principles of customary law. The first and second rule, depending on their specific workings, could fit with these principles of customary law while also offering space for social evolution and the demands of modernity. The selection of one of these two rules would thus be in accordance with the wider framework of customary law.

It is difficult to know whether Ghanaian officials in practice follow these two normative bench-marks, usus and opinio necessitatis. Judges, to start with one group of officials, almost always base their decisions on precedent (cf. Woodman I996: 43). They hardly ever acknowledge that they are creating or selecting a rule of customary law from the various existing practices. It is scarcely a topic of discussion among Ghanaian judges how changes in practice are to be reflected in judicial decisions. Some judges even deny that practice should influence judicial customary law, as becomes evident in this statement by High Court judge Baffoe Bonny: "Even when I know better I am bound to follow case law." 28 The few court cases that deal with the conversion and sale by traditional authorities of communal farmland for developmental purposes display that courts do not accept the third rule mentioned above, placing full unrestrained power in the hands of the chiefs. None of these cases, however, offers an extensive explanation as to how the judges come to their interpretation of customary law.

It is even more difficult to know how other officials determine what customary law is. Lawmakers, administrators and policy makers often do not make explicit how they have come to their decisions. The implementation of the LAP and the government's policy of non-interference 
imply, however, that often these officials leave the choice to the locality and follow the interpretation or practice of the most powerful local actor. They do not seem to pay much heed to judicial customary law. The third rule mentioned above, widely adhered to and practiced by traditional authorities, shows that focusing too much on the local reality and the current local practices of powerful actors as a guide to determine customary rules brings the risk of accepting 'whatever is out there' as customary law, regardless of its (in)consistency with the wider framework of customary law. An overemphasis on the negotiable nature of customary law can have the same effect, i.e., a de facto recognition of the outcome of local power struggles. Both approaches will therefore disproportionately benefit powerful local actors. Although customary law is to a certain extent negotiable, flexible, and relational in nature, this book posits that it does have normative content, which makes it possible to recognize deviations from the norms, even when they are legitimized with reference to alleged changed norms.

\section{Custom and state: looking ahead}

This book has analyzed customary land management in peri-urban Kumasi and its determining factors at the level of the locality, district, region, nation, and international arenas. This multi-level analysis showed the mutually constitutive relationships between traditional rule and local customary law on the one hand, and governmental administration, official versions of customary law, and state law on the other. We have seen that the reasons why chiefs can profit from the commodification of land include the fact that customary law does not constrain them, a lack of local checks and balances, and the government's 'policy of noninterference.' This constellation poses the dual question of whether problems of tenure security that the National Land Policy and the Land Administration Project aim to tackle can be solved within the sphere of customary law and chiefly rule and, if so, to what extent and how the national legal system can play a role in this process.

Let us be brief with regard to the first part of the question: can problems of tenure security be solved within the sphere of customary law and chiefly rule? First, the desirability of a transfer of local land management to governmental authorities can be questioned by the flawed record of the government of Ghana on various matters of administration and on land management in particular. ${ }^{29}$ Such a transfer would likely result in the dichotomy we see in so many other places: a government agency responsible for managing land which cannot possibly do so, in part because it does not have the required information, while chiefs go on doing the job, badly or well, but less transparently because 
legal sanction has been withdrawn. Second, the high popular allegiance to chieftaincy and the importance of customary law for many people make it hard to leave these features out of consideration, even if that would be deemed desirable. This research recognizes customary law and traditional leadership as realities of political life in contemporary Ghana, and concludes that problems of tenure security have to be solved in the sphere of customary law and traditional rule. As said before, this does not mean that the government should uncritically accept the way chiefs perform all their functions.

This brings us to the second part of the question: to what extent and how can the national legal system play a role in the enhancement of tenure security of customary land? First, this book has shown that only a small percentage of land conversion cases reaches the state courts, and decisions in these cases have limited effect outside the scope of the decided cases. Second, local land management is hardly influenced by state legislation, as it falls almost exclusively in the realm of customary law. ${ }^{30}$ Third, the creation of Land Sector Agencies with a mandate to check chiefly land management has not been very effective in the locality. It could be said that the main way the state currently influences local land management is through some administrative actions, or their absence, and through its discourse. Examples of the way government (in)activity influences the local power balance are found in the formalization of the chiefs' role through the establishment of Customary Land Secretariats and in land use planning in general; in the policy of noninterference with its omnipresent discourse; and in the unwillingness to back up local government representatives in their struggle for equitable land management. These examples all communicate the message that the chiefs have free reign in the field of customary land management, unrestricted and often even supported by the state, which will facilitate the chiefs' appropriation of communal rights, such as the conversion of peri-urban land in which community members have usufructuary rights.

The national legal system currently does not operate to guarantee tenure security of local smallholders and various recommendations can be made to affect a change in that area. Access to state courts should be enhanced and the processing time of cases shortened. Government should find ways in their administration to back up judicial customary law outside the realm of the decided cases. For instance, where LAP documents now talk of the need to clarify the legal interests of usufructuaries, government could base itself on judicial customary law. With regard to customary land management in general, and the CLS component of LAP in particular, government should spread the message of the legitimacy of community interests in land and actively propagate the need for accountability of the chiefs. There is a need to actively 
educate the people and strengthen civil society organizations to empower local farmers. This means a break with the current non-interference discourse, as 'the shadow of the state' is needed for an effective and equitable functioning of customary tenure systems. In situations where the customary rule is unclear, government needs to take into account the whole framework of customary norms, rules and practices, and should not uncritically accept claims by powerful actors, who are deviating from that framework, that norms have changed. Government should no longer favor working with (paramount) chiefs rather than the people out of administrative efficiency. With regard to land use planning, which now seems to enhance the position of chiefs through the formalization of certain procedures, government should aim to increase the participation of villagers in mapping and demarcation exercises. This will foster open discussion of the role and powers of chiefs and prevent the semblance of state backing for conversions of land by chiefs. Local initiatives to install a Plot Allocation Committee should be supported and consolidated by the District Assembly. In line with this, the activities of representatives of District Assemblies and Unit Committees in the villages should no longer be suppressed but rather welcomed by their superiors. They perform a necessary role in the control of chiefly land management, and their power is often needed in local struggles to compel more chiefly accountability. An additional way to increase chiefly accountability would be to establish a rule that the allocation papers need to state the amount of money, including 'drink money', paid to obtain rights in land. If government were to tackle the excesses of chiefly land management, this would not only benefit the smallholder but - although it would provoke serious opposition from chiefs - it would in the long run even benefit the interests of the chieftaincy class, as it could help the system as a whole to retain and/or regain the credibility necessary to function.

A number of conditions need to be fulfilled for such measures to be effective. These include the adequate funding, staffing, training, and equipping of Land Sector Agencies, local governments, and state courts; the tackling of problems of mismanagement and corruption within these institutions; and the existence of high-level political will. The latter seems to form the greatest challenge of all, especially within the current pro-chieftaincy NPP government. Here thus lies the role of international donors to keep their foot down with regard to issues of chiefly accountability and equity in customary land management. And if that is unfeasible under the current political constellation, their aim of poverty alleviation requires them to reconsider their support for programs that enhance the position of chiefs. Although a study like the present one cannot be expected to bring fundamental change to the political arena, it is hoped that the facts and narratives presented here at 
least provide a firm knowledge base to politicians, judges, legislators, policy makers, and donors, and diminish the risks of these actors to be misled by misinformation or ignorance.

\section{Notes}

I See chapter 3, footnote 56.

2 See chapter 3 and 4 .

3 See chapter 3.

4 See chapter 4.

See chapter 4 .

See chapter 3 at 59-60.

Id.

8 To some extent, state legislation and statements by state officials are also used as a local resource but in general claims are legitimized by referring to customary law.

9 See chapter 2.

Io For other examples see chapter 2.

II See chapter 2.

I2 Unreported judgment, no. 5/97 of I3 May I997.

I3 See chapter 6 .

I4 Id.

I5 $\mathrm{N}=242$.

I6 In a survey among 677 respondents, the people most frequently mentioned as 'trusted a lot' were, firstly, village chiefs (62.I\%), second family heads (61.4\%) and third court judges (35.4\%), with UC chairmen coming a close fourth (34.2\%) (Crook et al. 2005: 7377). See chapter 5 .

I7 Out of I53 respondents that said they had personally experienced a land dispute, only 26.I\% had turned in first instance to the chief, while $73.9 \%$ had initially taken other roads to settle the issue (Crook et al. 2005: 72). See chapter 5 .

I8 See chapter 3 .

I9 Article II (3) of the I992 Constitution.

20 This initial gap will increase when local practices evolve, while the formulated rule continues to exist in case law, legislation or policy documents.

2I In English law, to be recognized as customary law, a practice must have existed from time immemorial - a time long settled as II 89 , the accession of Richard I. The English doctrine of immemorially old custom was instituted in the I6thcentury as a new and effective weapon to limit the operation of custom. According to Plucknett, "the whole idea is as artificial as the date of limitation which it set" (Plucknett I948: 293). Ghanaian jurisprudence has rejected the notion of 'time immemorial' in the first quarter of the 2othcentury when it became realized that customary law was not a variation from some other law - as in England - but was, for its specified community, the general law applicable (Mensah v. Wiaboe (I925), selected judgments of the Divisional Courts of the Gold Coast Colony I92I-I925, I70: I72, reported in Allott I970: I52). The test of antiquity would deny new or changed customs recognition in the courts (Allen I958: 130; Hooker I975: I36; Mensa-Bonsu 2002-4: 4-6). Beyond this, no effort has been made in Ghana to provide an answer to the question how long it takes to establish a rule of customary law.

22 See chapter 3 for more literature. 
23 Article 267 (I) holds that "All stool lands in Ghana shall vest in the appropriate stool on behalf of, and in trust for the subjects of the stool in accordance with customary law and usage".

24 See chapter 6.

25 Busia I95I; Danquah I928; Dunn and Robertson I973: 53; Hayford I970; Kasanga 2000a; Kasanga 2002; Kwadwo I994; Ollennu 1962; Pogucki I962; Sarbah I968; Wehrmann 2002.

26 See chapter 3 .

27 Some notable examples of chiefs ignoring the needs of their people out of self-interest are found in Alden Wily and Hammond 200I; Amanor 1999; Berry I997; DFID 200I; Dunn and Robertson I973; Firmin-Sellers I995; McCaskie 2000b; Rathbone I996.

28 Personal communication, 5 September 2003.

29 See chapter 2.

30 Areas where the state has expropriated land form an exception to this rule. 


\section{References}

Abudulai, Sulemana. I996. Perceptions of land rights, rural-urban land use dynamics and policy development. In Managing Land Tenure and Resource Access in West Africa: Proceedings of a Regional Workshop held at Gorée, Sénégal, November 18-22, edited by Ministère de la Coopération, Overseas Development Administration, L'Université de Saint Louis, GRET and IIED. London: IIED.

-. 2002. Land rights, land-use dynamics \& policy in peri-urban Tamale, Ghana. In The Dynamics of Resource Tenure in West Africa, edited by C. Toulmin, P. Lavigne Delville and S. Traoré. London: IIED.

Acock, A.M. 1962. Land policies and economic development in East and Central Africa. Agricultural Economics Bulletin for Africa I (I): I-20.

Adams, Martin, Sipho Sibanda, and Stephen Turner. I999. Land tenure reform and rural livelihoods in Southern Africa. Natural Resource Perspectives 39.

Addo-Fening, Robert. I990. The Native Jurisdiction Ordinance, indirect rule and the subject's well-being: The Abuakwa experience c I899-I9I2. Research Review (Institute of African Studies) 6 (2): 29-44.

Alden Wily, Liz. 2003. Governance and Land Relations: A Review of Decentralization of Land Administration and Management in Africa. London: IIED.

Alden Wily, Liz, and Daniel N.A. Hammond. 20or. Land Security and the Poor in Ghana. Is There a Way Forward? DFID Ghana Rural livelihoods Program.

Alhassan, Osman, and Takyiwaa Manuh. 2005. Land Registration in Eastern and Western Regions, Ghana. Securing Land Rights in Africa Research Report 5. London: IIED.

Allen, C.K. I958. Law in the Making. London: Oxford University Press.

Allott, Anthony N. I960. Essays in African Law: With Special Reference to the Law of Ghana. Westport: Greenwood Press Publishers.

-. I970. New Essays in African Law. London: Butterworths.

-. I975. Essays in African Law: With Special Reference to the Law of Ghana. 2 ed. Westport: Greenwood Press Publishers.

-. I977. The people as law-makers: Custom, practice, and public opinion as sources of law in Africa and England. Journal of African Law 2I (I): I-23.

Allott, Anthony N., and Gordon R. Woodman, eds. 1985. People's Law and State Law: The Bellagio Papers. Dordrecht: Foris.

Amanor, Kojo Sebastian. 1994. The New Frontier: Farmers' Responses to Land Degradation. London: Zed Press.

-. 1999. Global Restructuring and Land Rights in Ghana. Uppsala: Nordiska Afrikainstitutet.

-. 200I. Land, Labour and the Family in Southern Ghana: A Critique of Land Policy under Neo-Liberalisation. Uppsala: Nordiska Afrikainstitutet.

- 2005. Global and local land markets: The role of the customary. In Land in Africa: Market Asset or Secure Livelihood? Proceedings and Summary of Conclusions from the Land in Africa Conference, November 8-9, in London, United Kingdom, edited by J. Quan, S. F. Tan and C. Toulmin. London: IIED, NRI, Royal African Society. 
-. 2006. Chapter six: Customary land, mobile labor and alienation in the Eastern Region of Ghana. In Land and the Politics of Belonging in West Africa, edited by R. Kuba and C. Lentz. Leiden, Boston: Brill.

- 2008, forthcoming. The changing face of customary land tenure. In Contesting Land and Custom in Ghana: State, Chief and the Citizen, edited by K. S. Amanor and J. M. Ubink. Amsterdam: Amsterdam University Press.

Amanor, Kojo Sebastian, and M.K. Diderutuah. 200I. Share Contracts in the Oil Palm and Citrus Belt of Ghana. London: IIED.

Annor, K. P. 1985. Cultural and social identities in Africa: Chieftaincy and political change in Ghana. Verfassung und Recht in Ubersee I8: 153-I59.

Antwi, Adarkwah Yaw. 2006. Strengthening customary land administration: A DFID/World Bank sponsored project in Ghana. Paper presented at the 5th FIG regional conference on 'Promoting land administration and good governance', March 8-II, in Accra, Ghana. http: //www.fig.net/pub/accra/techprog.htm.

Antwi, Adarkwah Yaw, and John Adams. 2003. Rent-seeking behaviour and its economic costs in urban land transactions in Accra, Ghana. Urban Studies 40 (IO): 2083-2098.

Appiah-Opoku, Seth, and George Mulamoottil. 1997. Indigenous institutions and environmental assessment: The case of Ghana. Environmental Management 2I (2): I59-I7I.

Asante, Samual K.B. I969. Interests in land in the customary law of Ghana: A new appraisal. University of Ghana Law Journal 6 (2): 99-139.

- 2003. African traditional systems and the growth of democracy and good governance. Paper presented at the 'Conference on African traditional leaders', August 3, in Kumasi, Ghana.

Asiama, Seth Opuni. 2003. Current changes in customary/traditional delivery systems in Sub-Saharan African cities - Ghana. Unpublished paper.

Atwood, D.A. I990. Land registration in Africa: The impact on agricultural production. World Development I8 (5): 659-67I.

Ault, D.E., and G.L. Rutman. 1979. The development of individual rights to property in tribal Africa. Journal of Law and Economics XXII (I): I63-I82.

Ayee, Joseph R.A. I999. Ghana. In Public Administration in Africa. Main Issues and Selected Country Studies, edited by L. Adamolekun. Boulder, Oxford: Westview Press.

Ayittey, George B.N. I99I. Indigenous African Institutions. Ardsley-on-Hudson: Transnational Publishers.

Bako-Arifari, Nassirou. I999. Traditional local institutions, social capital and the process of decentralisation. A typology of government policies in developing countries. In Working papers on African societies. Berlin: Das Arabische Buch.

Bassett, T.J. I993. Introduction: The land question and agricultural transformation in subSaharan Africa. In Land in African Agrarian Systems, edited by T. J. Bassett and D. E. Crummey. Wisconsin: University of Wisconsin Press.

Benjaminsen, Tor A., and Christian Lund. 2003a. Formalisation and informalisation of land and water rights in Africa: An introduction. In Securing Land Rights in Africa, edited by T. A. Benjaminsen and C. Lund. London: Frank Cass.

-. eds. 2003b. Securing Land Rights in Africa. London: Frank Cass.

Benjaminsen, Tor A., and E. Sjaastad. 2003. Race for the prize: Land transactions and rent appropriation in the Malian cotton zone. In Securing Land Rights in Africa, edited by T. A. Benjaminsen and C. Lund. London: Frank Cass.

Benneh, G. I967. Communal land tenure and the problem of transforming traditional agriculture in Ghana. Journal of Administration Overseas I5 (I): 26-33.

-. I97I. Rural land tenure systems in Ghana and their relevance to agricultural development. Paper presented at the 'Seminar on Problems of Land Tenure in African Development', December I3-I7, in Leiden, The Netherlands. 
Bennett, T.W. I985. Application of Customary Law in Southern Africa. The Conflict of Personal Laws. Cape Town, Wetton, Johannesburg: Juta \& Co.

Berge, Erling 2006. Power relations and security of tenure in Malawi's land law. Paper presented at the 'Eleventh Biennial Conference of the International Association for the Study of Common Property', June I9-23, in Bali, Indonesia.

Berry, Sara. I988. Concentration without privatization? Some consequences of changing patterns of rural land control in Africa. In Land and Society in Contemporary Africa., edited by R. E. Downs and S. P. Reyna. Hannover, London: University Press of New England.

-. I993. No Condition is Permanent. The Social Dynamics of Agrarian Change in SubSaharan Africa. Madison: The University of Wisconsin Press.

- I997. Tomatoes, land and hearsay: Property and history in Asante in the time of structural adjustment. World Development 25 (8): I225-I24I.

- 200I. Chiefs Know Their Boundaries: Essays on Property, Power, and the Past in Asante, I896-I996. Portsmouth: Heinemann.

- 2002a. The everyday politics of rent-seeking: Land allocation on the outskirts of Kumase, Ghana. In Negotiating Property in Africa, edited by K. Juul and C. Lund. Portsmouth: Heinemann.

-. 2002b. Negotiable property: Making claims on land and history in Asante, I896-I996. In Contested Terrains and Constructed Categories. Contemporary Africa in Focus., edited by G. C. Bond and N. C. Gibson. Boulder, Col.: Westview.

Bierschenk, Th. I993. The creation of a tradition. Fulani chiefs in Dahomey/Bénin from the late I9th century. Paideuma 39: 2I7-244.

Boafo-Arthur, Kwame. 200I. "Tradition" against the state? Confronting chiefs and state authority in Ghana. Paper presented at the African Studies Centre Seminar, May 9, in Leiden, The Netherlands.

-. 2003. Chieftaincy in Ghana: Challenges and prospects in the 2Ist Century. African and Asian Studies 2 (2): I25-I54

Bohannan, Paul. I957. Justice and Judgement among the Tiv. London: Oxford University Press.

-. I963. 'Land', 'tenure' and land tenure. In African Agrarian Systems, edited by D. P. Biebuyck. Oxford: Oxford University Press, International African Institute.

- I967. The differing realms of the law. In Law and Warfare, edited by P. Bohannan. Garden City, NY: Natural History Press.

Boni, Stefano. 2006. Indigenous blood and foreign labor: The ancestralization of land rights in Sefwi (Ghana). In Land and the Politics of Belonging in West Africa, edited by R. Kuba and C. Lentz. Leiden, Boston: Brill.

Bourdieu, Pierre. I990. In Other Words: Essays Towards a Reflexive Sociology. Cambridge: Polity Press.

Brempong, Arhin. 200I. Transformations in Traditional Rule in Ghana (I95I-I996). Accra: Sedco.

Brobbey, S.A. 2000. Practice and Procedure in the Trial Courts \& Tribunals of Ghana, Vol. I. Accra: Black Mask Ltd.

Brokensha, D., and J. Glazier. I973. Land reform among the Mbeere of central Kenya. Africa 43 (3): $182-206$.

Bruce, John W. I988. A perspective on indigenous land tenure systems and land concentration. In Land and Society in Contemporary Africa, edited by R. E. Downs and S. P. Reyna. Hannover, London: University Press of New England.

Bruce, John W., and Shem E. Migot-Adholla, eds. I994. Searching for Land Tenure Security in Africa. Dubuque: Kendall/Hunt Publishing Company.

Bruce, John W., Shem E. Migot-Adholla, and Joan Atherton. I994. The findings and their policy implications: Institutional adaptation or replacement? In Searching for Land Te- 
nure Security in Africa, edited by J. W. Bruce and S. E. Migot-Adholla. Dubuque: Kendall/Hunt Publishing Company.

Busia, K.A. I95I. The Position of the Chief in the Modern Political System of Ashanti: A Study of the Influence of Contemporary Social Changes on Ashanti Political Institutions. London, New York, Toronto: Oxford University Press.

Buur, Lars, and Helene Maria Kyed. 2005. State Recognition of Traditional authority in Mozambique. The Nexus of Community Representation and State Assistance. Uppsala: Nordiska Afrikainstitutet.

Carney, Judith, and Michael Watts. I990. Manufacturing dissent: Work, gender and the politics of meaning in a peasant society. Africa 60 (2): 207-24I.

Centre for Democracy and Development. 2000. The Ghana Governane and Corruption Survey. Evidence from Households, Enterprises and Public Officials. Accra: CDD.

Chanock, Martin. I989. Neither customary nor legal: African customary law in an era of family law reform. International Journal of Law and the Family 3: I72-187.

-. I998. Law, Custom and Social Order: The Colonial Experience in Malawi and Zambia. Cambridge: Cambridge University Press.

Chauveau, Jean Pierre, Jean Philippe Colin, Jean Pierre Jacob, Philippe Lavigne Delville, and Pierre Yves Le Meur. 2006. Changes in Land Access, Institutions and Markets in West Africa. London: IIED.

Claassens, Aninka. 2006. Land rights, power and traditional leaders. The Communal Land Rights Act of 2004. In Acta Juridica.

Coldham, Simon. I979. Land tenure reform in Kenya: the limits of law. The Journal of Modern African Studies I7 (4): 6I5-627.

Collier, J.F. I988. Marriage and Inequality in Classless Society. Stanford: Stanford University Press.

Comaroff, John L. I975. Talking politics: Oratory and authority in a Tswana chiefdom. In Political Language and Oratory in Traditional Society, edited by M. Bloch. London, New York, San Francisco: Academic Press.

Comaroff, John L., and Simon Roberts. I981. Rules and Processes: The Cultural Logic of Dispute in an African Context. Chicago: University of Chicago Press.

Cotran, E. I968-9. Restatement of African Law, Kenya. Volume r: The Law of Marriage and Divorce. Volume 2: The Law of Succession. London: Sweet \& Maxwell.

Cotula, Lorenzo, Camilla Toulmin, and Ced Hesse. 2004. Land Tenure and Administration in Africa: Lessons of Experience and Emerging Issues. London: IIED.

Cousins, Ben. 2000. Tenure and common property resources in Africa. In Evolving Land Rights, Policy and Tenure in Africa, edited by C. Toulmin and J. Quan. London: DFID/ IIED/NRI.

-. 2002. Legislating negotiability: Tenure reform in post-apartheid South Africa. In Negotiating Property in Africa, edited by K. Juul and C. Lund. Portsmouth: Heinemann.

Crook, Richard C. I986. Decolonization, the colonial state, and chieftaincy in the Gold Coast. African Affairs 85 (338): 75-105.

-. I99I. Decentralisation and participation in Ghana and Côte d'Ivoire. In Government and Participation: Institutional Development, Decentralisation and Democracy in the Third World, edited by R. C. Crook and A. M. Jerve. Bergen: Chr. Michelsen Institute.

- 2003. Land cases in the Ghanaian Courts. Paper presented at the Accra Roundtable on 'Land Rights and Legal Institutions in Ghana and La Cote d'Ivoire', September 5, in Accra, Ghana.

- 2005. The Role of Traditional Institutions in Political Change and Development. CDD/ ODI Policy Brief No. 4, November 2005.

Crook, Richard C., Simplice Affou, Daniel N.A. Hammond, Adja F. Vanga, and Marc O. Yeboah. 2005. The Law, Legal Institutions and the Protection of Land Rights in Ghana 
and Cote d'Ivoire: Developing a More Effective and Equitable System. Final Report SSRU Project R 7993 .

Crothers, Charles. 2003. Social characteristics of traditional leaders and public views on their political roles. In Grassroots Governance? Chiefs in Africa and the Afro-Caribbean, edited by D. I. Ray and P. S. Reddy. Calgary: University of Calgary Press.

d'Engelbronner-Kolff, F.M., M.O. Hinz, and J.L. Sindano, eds. I998. Traditional Authority and Democracy in Southern Africa. Windhoek: Centre for Applied Social Sciences, University of Namibia.

Da Rocha, B.J., and C.H.K. Lodoh. I999. Ghana Land Law and Conveyancing. 2nd ed. Accra: DR \& L Print. and Pub. Services.

Daley, Elizabeth, and Mary Hobley. 2005. Land: Changing Contexts, Changing Relationships, Changing Rights. Paper for the Urban-Rural Change Team, DFID.

Daneel, M.L. I996. Environmental reform. A new venture of Zimbabwe's traditional custodians of the land. Journal of Legal Pluralism 37-38: 347-376.

Dañino, Roberto. 2005. Customary law systems as vehicles for providing equitable access to justice for the poor and local governance, the Peruvian experience. Paper presented at the 'Leadership Dialogue with Traditional Authorities', December 5, in Kumasi, Ghana.

Danquah, J B. I928. Gold Coast: Akan Laws and Customs and the Akim Abuakwa Constitution. London: Routledge.

De Soto, Hernando. 200I. The Mystery of Capital. Why Capitalism Triumphs in the West and Fails Everywhere Else. London: Black Swan.

De Sousa Santos, B. 1987. Law: A map of misreading: Towards a postmodern conception of law. Journal of Law and Society I4: 279-302.

Deininger, Klaus, and Hans Binswanger. 1999. The evolution of the World Bank's land policy: Principles, experience, and future challenges. The World Bank Research Observer I4 (2): $247-76$.

Demsetz, H. I967. Towards a theory of property rights. The American Economic Review 57 (2): 347-359.

Dennis, P.C.W. I957. A note on land revenue and local government in Ghana. Journal of African Administration 9 (2): 84-88.

DFID. 1999. Land Rights and Sustainable Development in Sub-Saharan Africa: Lessons and Ways Forward in Land Tenure Policy. Report of a Delegate Workshop on Land Tenure Policy in African Nations. Berkshire: DFID.

- 200I. Further Knowledge of Livelihoods Affected by Urban Transition, Kumasi, Ghana. Natural Resources Systems Programme. Final Technical Report. Accra: DFID.

- 2004. Project Memorandum: Ghana Land Administration Project Institutional Reform \& Development: Strengthening Customary Land Administration. Toulmin, C., Brown, D., Crook, R.

Downs, R.E., and S.P. Reyna, eds. I988. Land and Society in Contemporary Africa. Hannover, London: University Press of New England.

Dunn, John, and A.F. Robertson. 1973. Dependence and Opportunity: Political Change in Ahafo. Cambridge: Cambridge University Press.

Edusah, Sampson E, and David Simon. 200I. Land Use and Land Allocation in Kumasi Peri-urban Villages. CEDAR/IRNR Kumasi paper 9, DFID Project R7330., http: //www. gg.rhul.ac.uk/kumasi/Project_Related_Papers/Cedar_IRNR/Paper_9/paper_9.html.

Ehrlich, E. 1936. Fundamental Principles of the Sociology of Law. Translated by W. L. Moll. Cambridge: Harvard University Press.

Ekow Daniels, W.C. I99I-2. Development of customary law. The review of Ghana Law XVIII: 68-94. 
Elias, T.O. I958. The problem of reducing customary laws to writing. In Legal Papers Presented to the Fifth International Congress of Comparative Law, August 4-9, in Brussels. London: Stevens \& Sons.

Englebert, Pierre. 2002. Patterns and theories of traditional resurgence in tropical Africa. Mondes en Développement 30 (II8): 5I-64.

EU. 2004. EU Land Policy Guidelines. Guidelines for Support to Land Design and Land Policy Reform Processes in Developing Countries. EU Task Force on Land Tenure.

Fallers, Lloyd. I955. The predicament of the modern African chief: An instance from Uganda. American Anthropologist 57 (2): 290-305.

Feder, G., and R. Noronha. I987. Land rights systems and agricultural development in subSaharan Africa. Research Observer 2 (2): I43-I69.

Feder, G., T. Onchan, Y. Chalamwong, and C Hongladarom. I988. Land Policies and Farm Productivity in Thailand. Baltimore, London: John Hopkins University Press.

Field-Juma, A. I996. Governance and sustainable development. In In Land We Trust: Environment, Private Property and Constitutional Change, edited by C. Juma and J. B. Ojwang. London: Zed Books.

Firmin-Sellers, Kathryn. I995. The politics of property rights. The American Political Science Review 89 (4): 867-88I.

Fisiy, Cyprian F. I992. Power and Privilege in the Administration of Law: Land Law Reforms and Social Differentiation in Cameroon. Leiden: African Studies Centre.

Fitzpatrick, Daniel. 2005. 'Best practice' options for the legal recognition of customary tenure. Development and Change 36 (3): 449-475.

Fitzpatrick, Peter. I984. Traditionalism and traditional law. Journal of African Law 28 (I \& 2): $20-27$.

Fortes, M. I962. Ritual and office in tribal society. In Essays on the Ritual of Social Relations, edited by M. Gluckman. Manchester: Manchester University Press.

Franken, H. I995. InLeiden tot de Rechtswetenschap. Seventh ed. Arnhem: Gouda Quint.

Fred-Mensah, Ben Kwame. 2000. Changes, Ambiguities and Conflicts: Negotiating Land Rights in Buem-Kator, Ghana. Baltimore: Johns Hopkins University.

Galanter, Marc. I98I. Justice in many rooms: Courts, private ordering, and indigenous law. Journal of Legal Pluralism I9: I-47.

Gerschenberg, Irving. I97I. Customary land tenure as a constraint on agricultural development: A re-evaluation. East African Journal of Rural Development 4 (I): 5I-62.

Glazier, J. I985. Land and the Uses of Tradition among the Mbeere of Kenya. Lanham: University Press of America.

Gluckman, Max. I955. The Judicial Process among the Barotse of Northern Rhodesia. Manchester: Manchester University Press.

Goody, J.R. I962. Death, Property and the Ancestors: A Study of the Mortuary Customs of the LoDagaa of West Africa. Stanford: Tavistock Publications.

-. I979-80. Rice-burning and the green revolution in Northern Ghana. The Journal of Development Studies I6 (2): I36-I55.

Gough, Katherine V., and Paul W.K. Yankson. 2000. Land markets in African cities: The case of peri-urban Accra, Ghana. Urban Studies 37 (I3): I485-I500.

Grant, D. 2004. Institutional Arrangements Review, Land Sector, Ghana. Accra: Ministry of Lands and Forestry.

Griffiths, John. I986. What is legal pluralism? Journal of Legal Pluralism 24: I-50.

GSS. 2002. Population and Housing Census Report 2000. Accra: GSS.

Gulliver, P.H. I963. Social control in an African society: A study of the Arusha: Agricultural Masai of northern Tanganyika. In International Library of Sociology and Social Reconstruction, edited by W. J. H. Sprott. London: Routledge \& Kegan Paul. 
—. I979. Disputes and Negotiations. A Cross-cultural Perspective. New York, London, Toronto, Sydney, San Francisco: Academic Press.

Gyan, Kwame. 2005. Article 267(5) of the 1992 Constitution and the Death of the Freehold Interest in Stool Land in Ghana. Unpublished position paper for the Ministry of Lands, Forestry and Mines, accepted by the Attorney General's office.

Hagan, G.P. 2003. Chieftaincy the way forward - new wines and broken bottles. Paper presented at the conference on 'Chieftaincy in Africa: Culture, Governance and Development', 6-Io January, in Accra, Ghana.

Hammond, Daniel N.A. 2005. Protection of land rights and relations between state and customary authorities in Kumasi and Wa. Paper presented at the 'Workshop on Adjudication of Land Disputes, Legal Pluralism and the Protection of Land Rights in Ghana and Cote d'Ivoire', February I7-I8, in London, United Kingdom.

Hayford, J.E.C. I970. Gold Coast Native Institutions: With Thoughts upon a Healthy Imperial Policy for the Gold Coast and Ashanti. London: Frank Cass \& Co. Ltd. Original edition, I903.

Heller, Michael A. I998. The tragedy of the anticommons: Property in the transition from Marx to markets. Harvard Law Review III (3): 62I-688.

Herbst, Jeffrey. 2000. States and Power in Africa. Comparative Lessons in Authority and Control. Princeton, New Yersey: Princeton University Press.

Hill, Polly. I963. The Migrant Cocoa-Farmers of Southern Ghana. A study in Rural Capitalism. Cambridge: Cambridge University Press.

Hinz, Manfred O. 2003. Without Chiefs There Would Be No Game. Customary Law and Nature Conservation. Windhoek: Out of Africa Publishers.

- ed. 2006. The Shade of New Leaves. Governance in Traditional Authority: a Southern African Perspective. Berlin: Lit Verlag.

Hoebel, E. Adamson. I954. The Law of Primitive Man. Cambridge: Harvard University Press.

Hogue, Arthur R. I906. Origins of the Common Law. Indianapolis: LibertyPress.

Holleman, J.F. I973. Trouble-cases and trouble-less cases in the study of customary law and legal reform. Law \& Society Review 7 (4): 585-609.

Hooker, M.B. I975. Legal Pluralism. An Introduction to Colonial and Neo-colonial Laws. Oxford: Clarendon Press.

$\mathrm{Hu}$, Wei. I997. Household land tenure reform in China: Its impact on farming land use and agro-environment. Land Use Policy I4 (3): I75-I86.

Hueber, Sandra, and Chris de Veer. I993a. Case Study of the Land Use Pattern in a Neighbourhood in the Urban Fringe of Kumasi, Ghana. Amsterdam: Institute of Planning and Demography.

-. 200I. Urban spatial management in Kumasi. In The Fate of the Tree: Planning and Managing the Development of Kumasi, Ghana, edited by K. K. Adarkwa and J. Post. Accra: Woeli Publishing Services.

Ibik, J.O. I970-I. Restatement of African Law, Botswana. Volume I: The Law of Marriage and Divorce. Volume II: The Law of Land, Succession, Movable Property, Agreements and Civil Wrongs. London: Sweet \& Maxwell.

Just, Peter. I992. History, power, ideology, and culture: Current directions in the anthropology of law. Law \& Society Review 26 (2): 373-4II.

Juul, Kristine , and Christian Lund. 2002a. Negotiating Property in Africa. Portsmouth: Heinemann.

Juul, Kristine, and Christian Lund. 2002b. Negotiating Property in Africa: Introduction. In Negotiating Property in Africa, edited by K. Juul and C. Lund. Portsmouth: Heinemann. 
Kanji, Nazneen, Lorenzo Cotula, Thea Hilhorst, Camilla Toulmin, and Wray Witten. 2005. Research Report I. Can Land Registration Serve Poor and Marginalised Groups? Summary Report. London: IIED.

Kasanga, Kasim. I994. Land Tenure Systems and Ecological Degradation in Northern Ghana. What Role for Local Authorities? London: The Royal Institution of Chartered Surveyors.

-. 1996. Land tenure, resource access and decentralisation: The political economy of land tenure in Ghana. In Managing Land Tenure and Resource Access in West Africa: Proceedings of a Regional Workshop held at Gorée, Sénégal, November i8-22, edited by Ministère de la Coopération, Overseas Development Administration, L'Université de Saint Louis, GRET and IIED. London: IIED.

-. 2000a. Changes in land tenure. Paper presented at the 'Final Workshop of the Kumasi Natural Resources Management Research', February 9-II, in Kumasi, Ghana.

- 200ob. Land administration reforms and social differentiation. A case study of Ghana's Lands Commission. Paper presented at the 'International Workshop on the Rule of Law and Development', I-3 June, in Brighton, United Kingdom.

- 2002. Land tenure, resource access \& decentralisation in Ghana. In The Dynamics of Resource Tenure in West Africa, edited by C. Toulmin, P. Lavigne Delville and S. Traoré. London: IIED.

Kasanga, Kasim, Jeff Cochrane, Rudith King, and Michael Roth. I996. Land Markets and Legal Contradictions in the Peri-Urban Area of Accra Ghana: Informant Interviews and Secondary Data Investigations. LTC Research Paper 127. Madison, Kumasi: Land Tenure Center.

Kasanga, Kasim, and Nii Ashie Kotey. 200I. Land Management in Ghana: Building on Tradition and Modernity. London: IIED.

Kasanga, Kasim, and Gordon R. Woodman. 2004. Ghana: Local law making and land conversion in Kumasi, Ashanti. In Local Land Law and Globalization: A Comparative Study of Peri-Urban Areas in Benin, Ghana and Tanzania, edited by G. R. Woodman, U. Wanitzek and H. Sippel. Münster: Lit Verlag.

Kenton, Nicole. I999. Land Tenure and Resource Access in West Africa: Issues and Opportunities for the Next Twenty Five Years. London: IIED.

Keulder, C. 1998. Traditional leaders and rural development. In Traditional Authority and Democracy in Southern Africa, edited by F. M. d'Engelbronner-Kolff, M. O. Hinz and J. L. Sindano. Windhoek: Centre for Applied Social Sciences, University of Namibia.

Khadiagala, Lynn S. 200I. The failure of popular justice in Uganda: Local councils and women's property rights. Development and Change 32: 55-76.

Kludze, A.K.P. 1973. Restatement of African Law, Ghana. Volume I: Ewe Law of Property. London: Sweet \& Maxwell.

- 1985. Evolution of the different regimes of customary law in Ghana within the framework of stare decisis. In People's Law and State Law: The Bellagio Papers, edited by A. N. Allott and G. R. Woodman. Dordrecht: Foris.

Koesnoe, Mohammed. I985. From folk law towards jurists' law: A critical review of the state courts' practice concerning adat law in Indonesia (summary). In People's Law and State Law: The Bellagio Papers, edited by A. N. Allott and G. R. Woodman. Dordrecht: Foris Publications.

Kofi-Sackey, H. W. 1983. Chieftaincy, law and custom in Asante, Ghana. Jahrbuch für Afrikanisches Recht 4: 65-79.

Kotey, Nii Ashie. 1996. The 1992 Constitution and compulsory acquisition of land in Ghana: Opening new vistas? In Managing Land Tenure and Resource Access in West Africa: Proceedings of a Regional Workshop held at Gorée, Sénégal, November I8-22, edited by 
Ministère de la Coopération, Overseas Development Administration, L'Université de Saint Louis, GRET and IIED. London: IIED.

Kotey, Nii Ashie, Christine Dowuona-Hammond, and Raymond A. Atuguba. 2004. Ghana Land Administration Project Legislative and Judicial Review. Draft Final Report, 3I October 2004. Accra: Kotey \& Associates.

Kotey, Nii Ashie, and Marc O. Yeboah. 2003. GTZ Legal Pluralism and Gender Project (Land Law Focal Area). Report of a Study on Peri-Urbanism, Land Relations and Women in Ghana. Accra: GTZ.

Kumado, C.E.K. I990-I992. Chieftaincy and the law in modern Ghana. University of Ghana Law Journal XVIII: I94-216.

Kuper, Adam. 2003. The return of the native. Current Anthropology 44 (3): 389-402.

Kwadwo, Osei. 1994. An Outline of Asante History. Wiamoase-Ashanti: O. Kwadwo Enterprise.

Kyed, Helene, and Lars Buur. 2005. New roles for traditional leaders in resource mobilisation and rural development: Expectations, obstacles and conflicts. Paper presented at the Africa-Europe Group for Interdisciplinary Studies (AEGIS) conference, June 29- July 2, in London, United Kingdom.

Larbi, W.O., E. Odoi-Yemo, and L. Darko. Developing a geographic information system for land management in Ghana. GTZ I998. http: //www.gtz.de/orboden/capetown/cape4I. $\mathrm{htm}$

Lavigne Delville, Ph. I999. Harmonising Formal Law and Customary Land Rights in French-Speaking West Africa. London: IIED.

-. 2000. Harmonising formal law and customary land rights in French-speaking West Africa. In Evolving Land rights, Policy and Tenure in Africa, edited by C. Toulmin and J. Quan. London: DFID/IIED/NRI.

Lavigne Delville, Philippe, H. Ouedraogo, and Camilla Toulmin. 2002. Land tenure dynamics and government intervention. Paper presented at the International workshop for researchers and policy makers 'Making Land rights More Secure', March I9-2I, in Ouagadougou, Burkina Faso.

Lentz, Carola. 1998. The chief, the mine captain and the politician: Legitimating power in northern Ghana. Africa 68 (I): 46-67.

-. 2006. Is land inalienable? Historical and current debates on land transfers in Northern Ghana. Paper presented at the Colloque international 'Les frontières de la question foncière - At the frontier of land issues', May I7-I9, in Montpellier, France. http: //www. mpl.ird.fr/colloque_foncier/Communications/PDF/Lentz.pdf

Li, Guo, Scott Rozelle, and Loren Brandt. I998. Tenure, land rights, and farmer investment incentives in China. Agricultural Economics 19: 63-7I.

Lipsky, Michael. 1980. Street-Level Bureacracy. The Dilemmas of the Individual in Public Services. New York: Russell Sage Foundation.

Llewellyn, Karl N., and E. Adamson Hoebel. 194I. The Cheyenne Way. Conflict and Case Law in Primitive Jurisprudence. Norman: University of Oklahoma Press.

Lowy, Michael J. 1978. A good name is worth more than money: Strategies of court use in urban Ghana. In The Disputing Process: Law in Ten Societies, edited by L. Nader and H. F. Todd Jr. New York: Columbia University Press.

Lund, Christian. 2000. African Land Tenure: Questioning Basic Assumptions. London: IIED.

-. 2002. Negotiating property institutions: On the symbiosis of property and authority in Africa. In Negotiating Property in Africa, edited by K. Juul and C. Lund. Portsmouth: Heinemann.

- 2006. Who owns Bolgatanga? A story of inconclusive encounters. In Land and the Politics of Belonging in West Africa, edited by R. Kuba and C. Lentz. Leiden, Boston: Brill. 
Lund, Christian, and Gerti Hesseling. 1999. Traditional chiefs and modern land tenure law in Niger. In African Chieftaincy in a New Socio-Political Landscape, edited by E. A. B. Van Rouveroy van Nieuwaal and R. Van Dijk. Leiden: African Studies Centre.

Lutz, G, and W Linder. 2004. Traditional Structures in Local Governance for Local Development. Berne: Institute of Political Science, University of Berne.

Malinowski, Bronislaw. 1926. Crime and Custom in Savage Society. London: Kegan Paul, Trench, Trubner.

- I94I-2. A new instrument for the interpretation of law - especially primitive. Yale Law Journal 5I: I237-I254.

Mamdani, Mahmood. I996. Citizen and Subject: Contemporary Africa and the Legacy of Late Colonialism. Princeton: Princeton University Press.

Mann, Kirstin, and Richard Roberts, eds. I99I. Law in Colonial Africa. Portsmouth: Heinemann.

Mathieu, P., M. Zongo, and L. Paré. 2003. Monetary land transactions in Western Burkina Faso: Commoditisation, papers and ambiguities. In Securing Land Rights in Africa, edited by T. A. Benjaminsen and C. Lund. London: Frank Cass.

Maxwell, Daniel, W. Odame Larbi, G.M. Lamptey, S. Zakariah, and Margaret Armar-Klemesu. 1998. Farming in the Shadow of the City: Changes in Land Rights and Livelihoods in Peri-Urban Accra. Ottawa: The International Development Research Centre.

McCaskie, T.C. I984. Ahyiamu - 'A place of meeting': An essay on process and event in the history of the Asante state. Journal of African History 25: 169-188.

-. 1992. Review article. Empire state: Asante and the historians. Journal of African History 33: $467-476$.

-. I995. State and Society in Pre-colonial Asante. Cambridge: Cambridge University Press.

—. 2000a. Asante Identities: History and Modernity in an African Village I850-1950. Edinburgh: Edinburgh University Press.

- 200ob. The consuming passions of Kwame Boakye: An essay on agency and identity in Asante history. Journal of African Cultural Studies I3 (I): 43-62.

McClendon, Th. I995. Tradition and domestic struggle in the courtroom: Customary law and the control of women in segregation-era Natal. The International Journal of African Historical Studies 28 (3): 527 .

Mensa-Bonsu, H.J.A.N. 2002-4. Of "nuts in the ground not being groundnuts": The current state of customary law in Ghana. University of Ghana Law Journal XXII: I-24.

Merry, Sally Engle. 1988. Legal pluralism. Law \& Society Review 22 (5): 869-896.

-. I992. Anthropology, law and transnational processes. Annual Review of Anthropology 2I: 357-379.

Migot-Adholla, Shem E., and John W. Bruce. I994. Introduction: Are indigenous African tenure systems insecure? In Searching for Land Tenure Security in Africa, edited by J. W. Bruce and S. E. Migot-Adholla. Dubuque: Kendall/Hunt Publishing Company.

Migot-Adholla, Shem E., Peter Hazell, Benoit Blarel, and Frank Place. I993. Indigenous land rights systems in sub-Saharan Africa, a constraint on productivity? In The Economics of Rural Organization: Theory, Practice and Policy, edited by K. Hoff, A. Braverman and J. E. Stiglitz. New York: Oxford University Press.

Ministry of Lands and Forestry. 1999. National Land Policy. Accra: Ministry of Lands and Forestry.

-. 2003. Implementation Manual for Land Administration Project (LAP-I) (2003-2008).

Mnookin, R.H., and L. Kornhauser. 1979. Bargaining in the shadow of the law: The case of divorce. Yale Law Journal 88 (5): 950-997.

Moore, Sally F. 1970. Law and anthropology. In Biennual Review of Anthropology, edited by B. J. Siegel. Stanford: Stanford University Press. 
—. I973. Law and social change: The semi-autonomous social field as an appropriate subject of study. Law \& Society Review 7: 719-746.

-. 1978. Law as process: An anthropological approach. London: Routledge and Kegan Paul.

—. I986. Social Facts and Fabrications: "Customary" Law on Kilimanjaro, I880-1980. Cambridge: Cambridge University Press.

-. 1992. Treating law as knowledge: Telling colonial officers what to say to Africans about running "their own" Native Courts. Law \& Society Review 26 (I): II-46.

-. 1998. Changing African land tenure: Reflections on the incapacities of the state. European Journal of Development Research io (2): 33-49.

Mtengeti-Mgiro, Rosy. I991. Legal developments on women's rights to inherit land under customary law in Tanzania. Verfassung und Recht in Ubersee 24 (I): 362-37I.

Nader, Laura. 2002. The Life of the Law. Anthropological Projects. Berkeley: University of California Press.

-. ed. 1969. Law in Culture and Society. Chicago: Aldine.

Nader, Laura, and Harry F. Todd Jr. I978. The Disputing Process: Law in Ten Societies. New York: Columbia University Press.

National Commission for Civic Education. 1998. Unit Committees.

National Democratic Institute for International Affairs. I995. Chiefs: Traditional Authority and Democratic Governance in Malawi. A report on NDI program activities with Malawian chiefs in preparation for the national constitutional conference.

Ndulo, Muna. 198I. Ascertainments of customary law: Problems and perspectives with special reference to Zambia. African Social Research 31: 67-76.

Niskanen, W A. 1975. Bureaucrats and politicians. Journal of Law and Economics XVIII (3): 6I7-43.

—. I994. Bureaucracy and Public Economics. Aldershot: Edward Elgar.

North, D.C. I990. Institutions, Institutional Change and Economic Performance. Cambridge: Cambridge University Press.

NRI (Natural Resources Institute), and UST (University of Science and Technology). I997. Kumasi Natural Resource Management Research Project, Inception Report. Chatham: NRI.

Ntsebeza, Lungisile. 2003. Traditional authorities, local government and land rights. In Grassroots Governance? Chiefs in Africa and the Afro-Caribbean, edited by D. I. Ray and P. S. Reddy. Calgary: University of Calgary Press.

- 2005. Democarcy Compromised. Chiefs and the Politics of the Land in South Africa. Leiden, Boston: Brill.

Ntshona, Zoloile, and Edward Lahiff. 2003. Rural development, institutional change and livelihoods in the Eastern Cape, South Africa: A case study of Mdudwa village. Brighton: Institute of Development Studies.

Nugent, Paul. 1994. An abandoned project? The nuances of chieftaincy, development and history in Ghana's Volta Region. Paper presented at the confernce on 'The contribution of traditional authority to development, human rights and environmental protection', September 2-6, in Legon, Ghana.

Nukunya, G.K. I992. Tradition and Change in Ghana. An intoduction to Sociology. Accra: Ghana Universities Press.

Obeng, Ernest E. I988. Ancient Ashanti Chieftaincy. Tema: Ghana Publishing Corporation.

Odeneho Gyapong Ababio II. 2003. Welcome address. Paper presented at the 'Conference on African traditional leaders', August 3, in Kumasi, Ghana.

Odgaard, R. 2003. Scrambling for land in Tanzania: Processes of formalisation and legitimisation of land rights. In Securing Land Rights in Africa, edited by T. A. Benjaminsen and C. Lund. London: Frank Cass. 
Oduro-Kwarteng, Stephen. 2003. Environmental Implications of Indiscipline in the Land Market: A Case Study of the Kumasi Metropolis, Draft December 2003, Institute of mining and mineral engineering, Kwame Nkrumah University of Science and Technology, Kumasi.

Okany, Martin Chukwuka. I985. The Role of Customary Courts in Nigeria. Enugu: Fourth Dimension Publishing.

Okoth-Ogendo, H.W.O. 1976. African land tenure reform. In Agricultural Development in Kenya: An Economic Assessment, edited by J. Heyer, J. K. Maitha and W. M. Senga. Nairobi: Oxford University Press.

- I994. Land tenure, agrarian legislation and environmental management systems. In Land Tenure and Sustainable Land Use, edited by R. J. Bakema. Amsterdam: Royal Tropical Institute.

- 2000. Legislative approaches to customary tenure and tenure reform in East Africa. In Evolving Land Rights, Policy and Tenure in Africa, edited by C. Toulmin and J. Quan. London: DFID/IIED/NRI.

Ollennu, N.A. I962. Principles of Customary Land Law in Ghana. London: Sweet \& Maxwell.

- I967. Aspects of land tenure. In A Study of Contemporary Ghana. Volume two: Some Aspects of Social Structure, edited by Birmingham, Neustadt and Omaboe. London: George Allen \& Unwin Ltd.

Ollennu, N.A., and G.R. Woodman, eds. I985. Ollennu's Principles of Customary Land Law in Ghana. 2nd ed. Birmingham: CAL Press.

Omoding-Okwalinga, James. I984. Chiefs in Uganda: What do they want people to regard them as? Which extension workers seek their assistance? The Uganda Journal 4I: 23-3I.

Oomen, Barbara. I999. Group rights in post-apartheid South Africa. Journal of Legal Pluralism 44: 73-103.

- 2000. Tradition on the Move. Chiefs, Democracy and Change in Rural South Africa. Amsterdam: Netherlands Institute for South Africa (NiZA).

- 2002. Chiefs! Law, Power and Culture in Contemporary South Africa. Dissertation, Leiden University.

Osinbayo, Yemi, and Awa U. Kalu, eds. I991. Towards a Restatement of Customary Law. Lagos: Federal Ministry of Justice.

Ostrom, Elinor. I990. Governing the Commons: The Evolution of Institutions for Collective Action. Cambridge: Cambridge University Press.

Otto, J.M. I998. The supreme court of Niger and polynormativism in urban centres: A comment on Abdourahaman Chaïbou. Journal of Legal Pluralism 42: I7I.

Otumfuo Osei Tutu II, Asantehene. 2004. Traditional systems of governance and the modern state, Keynote address. Paper presented at the Fourth African Development Forum, October II-I5, in Addis Ababa, Ethiopia.

Otumfuo Osei Tutu II Education Fund n.d. http: //www.otumfuofund.org/america3.html.

Ouédraogo, R.S., J.-P. Sawadogo, V. Stamm, and T. Thombiano. I996. Tenure, agricultural practices and land productivity in Burkina Faso: Some recent empirical results. Land Use Policy I3 (3): 229-232.

Owusu-Sarpong, Christiane. 2003. Setting the Ghanaian context of rural local government: Traditional authority values. In Grassroots Governance? Chiefs in Africa and the AfroCaribbean, edited by D. I. Ray and P. S. Reddy. Calgary: University of Calgary Press.

Palmer, Robin. 2000. Land policy in Africa: Lessons from recent policy and implementation processes. In Evolving Land Rights, Policy and Tenure in Africa, edited by C. Toulmin and J. Quan. London: DFID/IIED/NRI.

Palmer, Vernon Valentine. 2004. From Lerotholi to Lando: Some examples of comparative law methodology. Global Jurist Frontiers 4 (2). 
Peters, Pauline E. 2002. The limits of negotiability: Security, equity and class formation in Africa's legal systems. In Negotiating Property in Africa, edited by K. Juul and C. Lund. Portsmouth: Heinemann.

-. 2004. Inequality and social conflict over land in Africa. Journal of Agrarian Change 4 (3): 269-3I4.

Place, Frank, Michael Roth, and Peter Hazell. I994. Land tenure security and agricultural performance in Africa: Overview of research methodology. In Searching for Land Tenure Security in Africa, edited by J. W. Bruce and S. E. Migot-Adholla. Dubuque: Kendall/ Hunt Publishing Company.

Platteau, J P. I996. The evolutionary theory of land rights as applied to Sub-Saharan Africa: A critical assessment. Development and Change 27: 29-86.

—. 2000. Does Africa need land reform? In Evolving Land Rights, Policy and Tenure in Africa, edited by C. Toulmin and J. Quan. London: DFID/IIED/NRI.

Plucknett, Theodore. I948. A Concise history of the Common Law. 4th ed. London: Butterworth.

Podedworny, Henryk. I97I. The customary land tenure: Selected problems of agrarian reforms and agricultural development in countries of Africa south of the Sahara. Africana Bulletin I5: 95-I22.

Pogucki, R.J.H. I962. The main principles of rural land tenure. In Agriculture and Land Use in Ghana, edited by B. Wills. London, Accra, New York: Oxford University Press.

Pospisil, Leopold. I958. Kapauku Papuans and Their Law. New Haven: Department of Anthropology, Yale University.

- I973. E. Adamson Hoebel and the anthropology of law. Law and Society Review 7 (4): 537-559.

Poulter, Sebastian. I975. An essay on African customary law research techniques: Some experiences from Lesotho. Journal of Southern African Studies I (2): I8I-I93.

Quan, Julian. 2000. Land tenure, economic growth and poverty in sub-Saharan Africa. In Evolving Land Rights, Policy and Tenure in Africa, edited by C. Toulmin and J. Quan. London: DFID/IIED/NRI.

Quan, Julian, and Adarkwah Yaw Antwi. 2008, forthcoming. State intervention in customary land management in Ghana. Risks and opportunities of development aid. In Contesting Land and Custom in Ghana: State, Chief and the Citizen, edited by K. S. Amanor and J. M. Ubink. Amsterdam: Amsterdam University Press.

Quisumbing, A.R., E. Payongayong, J.B. Aidoo, and K. Otsuka. 200I. Women's land rights in the transition to individualised ownership: Implications for tree-resource management in Western Ghana. Economic Development and Cultural Change 50 (I): I57-I82.

Radcliffe-Brown, A.R. I933. The Andaman Islanders. Cambridge: Cambridge University Press.

Ranger, Terence. I983. The invention of tradition in colonial Africa. In The Invention of Tradition, edited by E. Hobsbaum and T. Ranger. Cambridge: Cambridge University Press.

Rathbone, Richard. I993. Murder and Politics in Colonial Ghana. New Haven: Yale University Press.

-. I996. Defining Akyemfo: The construction of citizenship in Akyem Abuakwa, Ghana, I700-I939. Africa 66 (4): 506-525.

- 2000. Nkrumah \& the Chiefs. The Politics of Chieftaincy in Ghana I95I-60. Oxford: James Currey.

Rattray, R.S. I969, first published I929. Ashanti Law and Constitution. Oxford: Clarendon Press. 
Ray, D.I. I992. Contemporary Asante chieftaincy: Characteristics and development. In An African Commitment: Papers in Honour of Peter Lewis Shinnie, edited by J. Sterner and N. Davis. Calgary: University of Calgary Press.

-. I996. Divided sovereignty: Traditional authority and the state in Ghana. Journal of Legal Pluralism 37/38: I8I-202.

-. I998. Chief-state relations in Ghana - Divided sovereignty and legitimacy. In Sovereignty, Legitimacy, and Power in West African Societies: Perspectives from Legal Anthropology, edited by E. A. B. Van Rouveroy van Nieuwaal and W. Zips. Hamburg: Lit.

-. 2003a. Ghana: Traditional leadership and rural local governance. In Grassroots Governance? Chiefs in Africa and the Afro-Caribbean, edited by D. I. Ray and P. S. Reddy. Calgary: University of Calgary Press.

- 2003b. Rural local governance and traditional leadership in Africa and the Afro-Caribbean: Policy and research implications from Africa to the Americas and Australasia. In Grassroots Governance? Chiefs in Africa and the Afro-Caribbean., edited by D. I. Ray and P. S. Reddy. Calgary: University of Calgary Press.

Ray, D.I., and Gaëlle Eizlini. 2004. Chieftaincy, Sovereignty and Legitimacy and Development: A Pilot Newspaper Survey of the Role of Chiefs in Three Aspects of Development. Unpublished paper.

Ray, D.I., and P.S.. Reddy. 2003. Grassroots Governance? Chiefs in Africa and the Afro-Caribbean. Calgary: University of Calgary Press.

Ray, D.I., K. Sharma, and I.I. May-Parker, eds. I997. Symposium on Traditional Leadership and Local Government. Gaberone: 23-26 September.

Ray, D.I., and E.A.B. Van Rouveroy van Nieuwal. I996. The new relevance of traditional authorities in Africa. The conference; major themes; refelections on chieftaincy in Africa; future directions. Journal of Legal Pluralism 37/38: I-37.

Ribot, Jesse C. 200I. Local actors, powers and accountability in African decentralisation: Review of issues. In Georgetown International Environmental Law Review.

Roberts, Simon. I972. Restatement of African Law, Botswana. Volume I: Tswana Family Law. London: Sweet \& Maxwell.

-. I979. Order and Dispute. An Introduction to Legal Anthropology. Hammondsworth, Middlesex: Penguin Books.

Rose, Laurel L. I992. The Politics of Harmony: Land Dispute Strategies in Swaziland. Cambridge: Cambridge University Press.

Rubin, N.N. I965. The Swazi law of succession: A restatement. Journal of African Law 9 (2): 90-II3.

Sarbah, J.M. I968. Fanti Customary Laws. A brief Introduction to the Principles of the Native Laws and Customs of the Fanti and Akan Districts of the Gold Coast with a Report of some Cases thereon Decided in the Law Courts. Third ed. London: Frank Cass.

Schapera, Isaac. I938. A Handbook of Tswana Law and Custom: Compiled for the Bechuanaland Protectorate Administration. London: Oxford University Press.

Schott, Rüdiger. I980. Justice versus the law: Traditional and modern jurisdiction among the Bulsa of Northern Ghana. Law and state: a biannual collection of recent German contributions to these fields 2I: I23-I33.

Seidman, Robert B. I983-4. Rules of recognition in the primary courts of Zimbabwe: On lawyers' reasoning and customary law. Zimbabwe Law Review I \& 2: 43-7I.

Sharma, Keshav C. I997. Mechanisms for involvement of traditional leaders in the promotion of good governance. In Symposium on Traditional Leadership and Local Government, edited by D. I. Ray, K. Sharma and I. I. May-Parker. Gaberone: 23-26 September.

-. 2003. Traditional leadership and rural local government in Botswana. In Grassroots Governance? Chiefs in Africa and the Afro-Caribbean, edited by D. I. Ray and P. S. Reddy. Calgary: University of Calgary Press. 
Shipton, P. 2002. Foreword. In Negotiating Property in Africa, edited by K. Juul and C. Lund. Portsmouth: Heinemann.

Shipton, P., and M. Goheen. I992. Introduction. Understanding African land holding: Power, wealth and meaning. Africa 62 (3): 307-325.

Simo, John Mope. I996. Customary land tenure regimes in North-Western Cameroon: Evolution and interactions with wider economic and political development. Paper presented at the conference on 'Managing land tenure and resource access in West Africa', November I8-22, in Gorée, Sénégal.

Simon, D., K. Nsiah-Gyabaah, H. Warburton, V. Adu-Gyamfi, and D. McGregor. 20or. The Changing Urban-Rural Interface of African Cities: Conceptual Issues and an Application to Kumasi, Ghana. CEDAR/IRNR Kumasi paper I, DFID Project R7330. Royal Holloway, University of London and University of Science and Technology, Kumasi 200 I [cited 6 April 2006]. http: //www.gg.rhul.ac.uk/kumasi/Project_Related_Papers/Cedar_IRNR/ Paper_I/paper_I.html

Sjaastad, E., and D.W. Bromley. I997. Indigenous land rights in sub-Saharan Africa: Appropriation, security and investment demand. World Development 25 (4): 549-562.

Sklar, R.L. I999. The significance of mixed government in Southern African studies. In African Democracy in the Era of Globalisation, edited by J. Hyslop. Johannesburg: Witwatersrand University Press.

Snyder, Francis G. I98Ia. Anthropology, dispute processes and law: A critical introduction. British Journal of Law \& Society 8 (2): I4I-I80.

- . I98rb. Colonialism and legal form: The creation of "customary law" in Senegal. Journal of Legal Pluralism i9: 49-90.

Starr, June. 1978. Dispute and Settlement in Rural Turkey: An Ethnography of Law. Leiden: Brill.

Starr, June, and Jane F. Collier. I989. History and Power in the Study of Law: New Directions in Legal Anthropology. Ithaca, London: Cornell University Press.

Swindell, K, and A.B. Mamman. I990. Land Expropriation and accumulation in the Sokoto Periphery, Northwest Nigeria I976-86. Africa 60 (2): I73-187.

Tamanaha, Brian Z. I997. Realistic Socio-Legal Theory. Oxford: Oxford University Press.

Ter Haar, Barend, and R. Supomo. I950. Verzamelde Geschriften II. Djakarta: Noordhoff Kolff.

Thornton, Robert. 2003. Chiefs: Power in a political wilderness. In Grassroots Governance? Chiefs in Africa and the Afro-Caribbean, edited by D. I. Ray and P. S. Reddy. Calgary: University of Calgary Press.

Tonah, Steve. 2002. Fulani pastoralists, indigenous farmers and the contest for land in Northern Ghana. Afrika Spectrum 37 (I): 43-59.

Toulmin, Camilla. 2000. Decentralisation and land tenure. In Evolving Land Rights, Policy and Tenure in Africa, edited by C. Toulmin and J. Quan. London: DFID/IIED/NRI.

Toulmin, Camilla, Philippe Lavigne Delville, and Samba Traoré. 2002a. Introduction. In The Dynamics of Resource Tenure in West Africa, edited by C. Toulmin, P. Lavigne Delville and S. Traoré. London: IIED.

- eds. 2002b. The Dynamics of Resource Tenure in West Africa. London: IIED.

Toulmin, Camilla, and Judy Longbottom. 200I. West African Land: Rights, Poverty \& Growth. London: IIED.

Toulmin, Camilla, and Julian Quan. 2000a. Evolving land rights, tenure and policy in subSaharan Africa. In Evolving Land Rights, Policy and Tenure in Africa, edited by C. Toulmin and J. Quan. London: DFID/IIED/NRI.

-. 200ob. Registering customary rights. In Evolving Land Rights, Policy and Tenure in Africa, edited by C. Toulmin and J. Quan. London: DFID/IIED/NRI. 
—. eds. 2000c. Evolving Land Rights, Policy and Tenure in Africa. London: DFID/IIED/ NRI.

Tullock, G. 1976. The Vote Motive. An Essay in the Economics of Politics, with Applications to the British Economy. London: Institute of Economic Affairs.

Twining, William. I963. The restatement of African customary law: A comment. The Journal of Modern African Studies I (2): 22I-8.

Ubink, Janine M. 2002-2004. Courts and peri-urban practice: Customary land law in Ghana. University of Ghana Law Journal XXII: 25-77.

- 2007. Customary tenure security: Wishful policy thinking or reality? A case from periurban Ghana. Journal of African Law 5I (2): 215-248.

-. 2008, forthcoming. Land, chiefs and custom in peri-urban Ghana: Traditional governance in an environment of legal and institutional pluralism. In The Governance of Legal Pluralism., edited by W. Zips and M. Weilenmann. Münster: Lit Verlag.

Ubink, Janine M., and Julian F. Quan. 2008, in press. How to combine tradition and modernity? Regulating customary land management in Ghana. Land Use Policy 25 (2).

University of Sussex. Conflict, 'Post-conflict', and Traditional Authorities. Briefing. Institutions for Natural Resource Management. MZor. Brighton: University of Sussex.

USAID. 1986. USAID Policy Determination Land Tenure: USAID.

-. 2003. Country Strategic Plan 2004-20IO. Empowering Ghanaians through Partnership to Build a Prosperous Nation. Accra: USAID/Ghana.

Van Binsbergen, Wim. 1996. Nkoya royal chiefs and the Kazanga cultural association in western central Zambia today. Journal of Legal Pluralism 37-38: 97-I33.

—. I999. Nkoya royal chiefs and the Kazanga cultural association in western central Zambia today - resilience, decline or folkolorization? In African Chieftaincy in a New SocioPolitical Landscape, edited by E. A. B. Van Rouveroy van Nieuwaal and R. Van Dijk. Leiden: African Study Centre.

Van Dijk, R., and E.A.B. Van Rouveroy van Nieuwaal. 1999. Introduction: The domestication of chieftaincy in Africa: From the imposed to the imagined. In African Chieftaincy in a New Socio-Political Landscape, edited by E. A. B. Van Rouveroy van Nieuwaal and R. Van Dijk. Leiden: African Study Centre.

Van Leeuwen, F.K.C., and E.M. Van Steekelenburg. 1995. The Process of Land Acquisition: A Case Study of Kumasi. Amsterdam: Institute of Planning and Demography.

Van Rouveroy van Nieuwaal, E.A.B. 1987. Chiefs and African states: Some introductory notes and an extensive bibliography on African chieftaincy. Journal of Legal Pluralism 25/26: I-46.

-. 1996. States and chiefs: Are chiefs mere puppets? Journal of Legal Pluralism 37-38: 3978.

Van Rouveroy van Nieuwaal, E.A.B., and R. Van Dijk. I999. African Chieftaincy in a New Socio-Political Landscape. Leiden: African Study Centre.

Van Vollenhoven, Cornelis. I9I8. Het Adatrecht van Nederlans-Indië. Vol. I. Leiden: Brill.

Vanderlinden, J. I989. Return to legal pluralism: Twenty years later. Journal of Legal Pluralism 28: I49-157.

Vaughan, Olufemi. 2000. Nigerian Chiefs. Traditional Power in Modern Politics, I890sI990's. Rochester: University of Rochester Press.

-. 2003. Chiefs, Power and Social Change: Chiefship and Modern Politics in Botswana, I880s-I99os. Asmara: Africa World Press, Inc.

Von Benda-Beckmann, Franz. 1979. Property in Social Continuity: Continuity and Change in the Maintenance of Property Relationships through Time in Minangkabau, West Sumatra. The Hague: Nijhoff. 
- I984a. Law out of context: A comment on the creation of traditional law discussion. Journal of African Law 28 (I \& 2): 28-33.

- I985a. Some comparative generalisations about the differential use of state and folk institutions of dispute settlement. In People's law and State Law: The Bellagio Papers, edited by A.N. Allott and G. R. Woodman. Dordrecht: Foris Publications.

Von Benda-Beckmann, Franz, and Keebet Von Benda-Beckmann. I999. A functional analysis of property rights, with special reference to Indonesia. In Property Rights and Economic Development. Land and Natural Resources in Southeast Asia and Oceania, edited by T. Van Meijl and F. Von Benda-Beckmann. London, New York: Kegan Paul International.

Von Benda-Beckmann, Keebet. I984b. The Broken Stairways to Consensus: Village Justice and State Courts in Minangkabau. Dordrecht: ICG Printing.

- I985b. The use of folk law in West Sumatran state courts. In People's Law and State Law: The Bellagio Papers, edited by A.N. Allott and G. R. Woodman. Dordrecht: Foris Publications.

Von Benda-Beckmann, Keebet, and Fons Strijbosch, eds. 1985. Anthropology of Law in the Netherlands. Dordrecht: Foris.

Von Trotha, Trutz 1996. From administrative to civil chieftaincy: Some problems and prospects of African chieftaincy. Journal of Legal Pluralism 37/38: 79-108.

Walker, David. I980. The Oxford Companion to Law. Oxford: Clarendon Press.

Weber, Max. 1967. Max Weber on Law in Economy and Society. Edited with introduction and annotations by Max Rheinstein. Translated from Max Weber, Wirtschaft und Gesellschaft, second edition (1925) by Edward Schils and Max Rheinstein. New York: Simon and Schuster.

Wehrmann, B. 2002. The easiest way to make money is to sell land! Land conflicts in the peri-urban area of Accra, Ghana. Trialog. Journal for Planning and Building in the Third World $74(3): 26-32$.

Whitehead, Ann, and Dzodi Tsikata. 2003. Policy discourses on women's land rights in subSaharan Africa: The implications of the re-turn to the customary. Journal of Agrarian Change 3 (I and 2): 67-II2.

Wilks, I. I966. Aspects of bureaucratization in Ashanti in the nineteenth century. Journal of African History VII (2): 215-232.

-. I975. Asante in the Nineteenth Century - The Structure and Evolution of a Political Order. Cambridge: Cambridge University Press.

- I993. Forests of Gold: Essays on the Akan and the Kingdom of Asante. Athens: Ohio University Press.

—. I998. "Unity and progress": Asante politics revisited. Ghana Studies I: I5I-I79.

Wood, Georgina T. 2002. The Courts and Land Disputes in Ghana: Situation, Problems and Way Forward. Accra: German Technical Co-operation.

Woodhouse, Philip. 2003. African enclosures: A default mode of development. World Development 3I (10): 1705-1720.

Woodman, Gordon R. I969. Some realism about customary law: The West African experience. Wisconsin Law Review: I28-152.

-. I977. Judicial development of customary law: The case of marriage law in Ghana and Nigeria. University of Ghana Law Journal I4 (2): II5-I36.

-. I98I-2. Land use policy and the extent of the usufruct. Review of Ghana Law XIII-XIV: 200-204.

- I988. How state courts create customary law in Ghana and Nigeria. In Indigenous Law and the State, edited by B. W. Morse and G. R. Woodman. Dordrecht: Foris Publications.

-. 1996. Customary land law in the Ghanaian courts. Accra: Ghana Universities Press. 
Woodman, Gordon R., Ulrike Wanitzek, and Harald Sippel, eds. 2004. Local Land Law and Globalization. A Comparatve Study of Peri-Urban Areas in Benin, Ghana and Tanzania. Münster: Lit Verlag.

World Bank. 1975. Land Reform. Sector Policy Paper. Washington: World Bank.

-. 2003a. Ghana Land Administration Project. Washington: World Bank.

- 2003b. Land Policies for Growth and Poverty Reduction. Washington: World Bank.

-. 2003c. Promoting Partnerships with Traditional Authorities Project. Washington: World Bank.

Yudelman, M. 1964. Some aspects of African agricultural development. In Economic Development for Africa South of the Sahara. Proceedings of a Conference Held by the International Economic Association, edited by E. A. G. Robinson. London: Macmillan.

Zorn, Jean G., and Jennifer C. Care. 2002. Proving Customary Law in the Common Law Courts of the South Pacific. London: British Institute of International and Comparative Law. 


\section{Samenvatting}

\section{In het land van de chiefs}

Gewoonterecht, grondconflicten en de rol van de staat in peri-urbaan Ghana

Dit proefschrift gaat over gewoonterecht en traditioneel leiderschap in Ghana. Het bestudeert het functioneren van deze twee instituties aan de hand van lokaal grondbeheer in gebieden rondom grote steden, zogenaamde peri-urbane gebieden. In internationale beleidskringen is men teruggekomen van het idee dat individuele eigendomsrechten de panacee zijn voor alle problemen. Gewoonterechtelijk grondbeheer door traditionele leiders (chiefs) wordt nu aangeprezen als mechanisme voor algemene toegang tot en zekerheid van rechten op grond. Deze beleidsverandering valt samen met de liberaliseringsgedachte die sinds de jaren 90 in zwang is en een geslonken staat en gedecentraliseerd bestuur propageert.

Deze hernieuwde belangstelling voor gewoonterechtelijk grondbeheer, zo betoog ik in hoofdstuk I, lijkt meer ingegeven door het falen van projecten en programma's ter individualisering van grondbezit dan het resultaat van een positieve keuze op basis van een nauwgezette analyse van het functioneren van dergelijke beheerssystemen. Zij strookt namelijk niet met onderzoek dat heeft aangetoond dat in gebieden waar grond schaars en waardevol is - ten gevolge van bijvoorbeeld bevolkingsgroei, de uitbreiding van stedelijke bebouwing, of de ontwikkeling van nieuwe commerciële landbouwsectoren - de rechten van lokale boeren vaak weinig zeker zijn en hun toegang tot grond steeds verder wordt beperkt. Dit proces leidt geleidelijk tot groeiende ongelijkheid in de verdeling van grond en grondopbrengsten en vergroot de sociale differentiatie binnen gemeenschappen.

Dit roept verscheidene vragen op met betrekking tot het functioneren van traditionele leiders, en het lokale normatieve systeem, het gewoonterecht. Hoe reageren traditionele leiders wanneer grond een waardevol marktgoed wordt? Welk effect heeft hun bestuur op de zekerheid van rechten op grond en daarmee op het levensonderhoud van lokale boeren, en tot op welke hoogte kunnen deze boeren lokaal grondbeheer en traditioneel bestuur beïnvloeden? Welke factoren bepalen wie de winnaars en verliezers van commercialisering van grond zijn? Wat voor gevolgen heeft het grondbeheer van de traditionele leiders op hun positie en taken en op het instituut traditioneel leiderschap? Hoe proberen de verschillende actoren gewoonterecht te gebruiken, vervormen of creëren in dit proces, en welke factoren verklaren 
hun (gebrek aan) succes? Hoe, in welke mate en met welke doelstellingen heeft overheidsbeleid door de jaren heen getracht gewoonterechtelijk grondbeleid te reguleren, en wat voor effect had dit beleid? Zijn statelijke rechtbanken belangrijke actoren in de opkomende strijd om grond? Hoe en in welke mate vertaalt internationale beleidsdruk zich in nationaal beleid? Hoe gaan wetgevers, beleidsmakers en rechters te werk bij het interpreteren, toepassen en voortbouwen op (lokaal) gewoonterecht, waarom doen zij dat zo, en welke normatieve maatstaven zouden hen kunnen en moeten leiden in dit proces?

Dit boek probeert deze en soortgelijke vragen te beantwoorden aan de hand van veldwerk in peri-urbaan Ghana. Ook in Ghana heeft in de laatste decennia een waardetoename en toenemende commercialisering van grond plaatsgevonden. In vergelijking met andere Afrikaanse landen hebben de traditionele leiders in dit land bovendien een uitzonderlijk sterke positie en een overheersende rol in grondbeheer. Daarom vormt Ghana een geschikte casus om het functioneren van traditioneel bestuur, gewoonterecht, en gewoonterechtelijke grondsystemen te bestuderen. Dit is zeker zo in dorpen rondom Kumasi, een sterk uitbreidende stad die het centrum vormt van de Ashanti regio, waar traditioneel leiderschap nog meer dan elders in Ghana een levend deel van de samenleving uitmaakt.

Hoofdstuk 2 richt zich op de staat en beschrijft in welke mate, hoe en met welke doelstellingen Ghanese regeringen door de jaren heen gewoonterechtelijk grondbeheer door traditionele leiders hebben gereguleerd. Zijn er maatregelen genomen om de zekerheid van grondrechten van kleine boeren te vergroten en bovengenoemde groeiende ongelijkheid in de verdeling van grond en grondopbrengsten tegen te gaan? En zo ja, hoe effectief waren deze maatregelen? Het hoofdstuk beschrijft eerst de geschiedenis, de juridische mandaten en het daadwerkelijk functioneren van verschillende statelijke instituten op dit vlak, zoals de Lands Commission en de Office of the Administrator of Stool Lands. Het laat zien dat zij, ondanks hun juridisch mandaat, in werkelijkheid weinig controle hebben uitgeoefend op gewoonterechtelijk grondbeheer. Dit kan worden verklaard door de gebrekkige medewerking van traditionele leiders; de beperkte bereidheid van ambtenaren om lokale misstanden aan te vechten; het ontbreken van daadwerkelijke politieke steun voor bestuurlijke controle op traditioneel grondbeheer; de financiële, materiële en personele tekorten bij de statelijke instituten; en hun problemen op het gebied van corruptie en wanbestuur.

Het gebrek aan politieke steun, dat ook duidelijk naar voren komt in het statelijke discours in de media en in beleidsstukken, vormt een impliciet non-interventie beleid met betrekking tot traditioneel leiderschap. Dit beleid beïnvloedt ook de uitvoering van het Land Admini- 
stration Project Ghana, een in 2003 met steun van verscheidene internationale donoren opgesteld lange termijn overheidsprogramma om Ghana's grondbeheer te hervormen tot een rechtvaardig en zeker systeem. Het deelprogramma dat zich richt op de hervorming van de gewoonterechtelijke sector wordt geconfronteerd met problemen van gevestigde belangen van traditionele leiders, gebrek aan middelen, en de afwezigheid van een openbaar debat over het type instituties dat nodig is voor een rechtvaardig grondbeheer. Het project beoogt om de bevoegdheden van statelijke instituten met betrekking tot traditioneel grondbeheer over te dragen naar lokale secretariaten (Customary Land Secretariats) onder toezicht van traditionele leiders. Dit lijkt de eenvoudige grondgebruikers echter eerder rechten te ontnemen dan deze te versterken. Er is een aanzienlijk risico dat de overheid zich niet voldoende zal inzetten voor het inbouwen van juridische en politieke controlemechanismen. Kleine grondgebruikers hebben vaak niet de benodigde organisatiegraad om tegenwicht te bieden aan de macht van de traditionele leiders. Het versterken van de positie van deze leiders door middel van het financieren van lokale secretariaten zonder bepaalde controlemechanismen te bevorderen leidt tot een aanzienlijk risico dat machtige traditionele leiders de lokale secretariaten zullen gebruiken om hun politieke macht over grond te consolideren, met alle negatieve gevolgen voor armere, kwetsbaardere grondgebruikers van dien.

De veldwerkdata die worden besproken in hoofdstuk 3 laten zien dat in peri-urbaan Kumasi sprake is van een crisis in gewoonterechtelijk grondbeheer, doordat traditionele leiders rijk worden van de omzetting en verkoop van landbouwgrond - die in bezit was van lokale boeren voor woningbouw. Dit roept de vraag op hoe traditionele leiders de situatie zo naar hun hand kunnen zetten en waarom de veelvuldige en veelzijdige tegenstand van lokale boeren vaak zo weinig effectief is. In dit hoofdstuk wijs ik op een aantal verklarende factoren die respectievelijk in het traditionele systeem zelf en in de interactie met de staat liggen. De combinatie van erosie van gewoonterechtelijke controlemechanismen en het non-interventie beleid van de overheid met betrekking tot traditioneel leiderschap heeft het fragiele evenwicht tussen traditionele leiders en het volk verstoord. Dit heeft de traditionele leiders de macht gegeven om hun prominente positie als hoeder van de grond en experts in het gewoonterechtelijke domein te misbruiken en gewoonterecht te manipuleren om hun claims te legitimeren.

Er lijkt voldoende bewijs om te stellen dat de gebeurtenissen in periurbaan Kumasi geen uitzondering zijn. Ook veel andere gebieden in Afrika waar grond schaars is, laten een aantasting van zekerheid van grondenrechten zien, waarbij traditionele leiders vaak een negatieve rol spelen. Ondanks deze wijdverbreide crisis in gewoonterechtelijk grondbeheer vertoont internationaal beleid, zoals gezegd, momenteel her- 
nieuwde belangstelling voor dergelijke lokale systemen. Dit hoofdstuk waarschuwt dat een positieve houding ten opzichte van gewoonterechtelijke systemen niet zou moeten voortvloeien uit teleurstelling over de staat, noch gebaseerd zou moeten zijn op geïdealiseerde ideeën over gewoonterecht. Zij behoeft een solide onderbouwing vanuit kennis van het functioneren van gewoonterechtelijke systemen van grondbeheer in hedendaagse omstandigheden.

Een dergelijke solide onderbouwing wordt echter bemoeilijkt doordat er twee nogal gescheiden stromingen van onderzoek naar grondbeheer bestaan. De eerste stroming concentreert zich grotendeels op economische aspecten zoals investeringen in en productiviteit van grond en vergelijkt de economische effecten van respectievelijk statelijke en gewoonterechtelijke systemen van grondbeheer. De tweede stroming bestudeert gewoonterechtelijk grondbeheer en grondbezit voornamelijk als sociale processen. Deze onderzoekers doen meestal langdurig antropologisch veldwerk naar grondbeheer en de sociale systemen waarin dit plaatsvindt. Zij zijn gericht op de lokale arena en benadrukken de ambiguïteit en onderhandelbaarheid van rechten op grond. Waar de eerste stroming in constante dialoog is met nationale en internationale beleidsmakers, stonden onderzoekers van de tweede stroming daar lange tijd nogal terughoudend tegenover. Deze tweede stroming, met haar diepgaande analyse van het functioneren van gewoonterechtelijke grondsystemen, is echter onmisbaar voor het maken van goed geïnformeerd beleid. Enige meer recente literatuur probeert het gat te dichten en kennis over lokaal grondbeheer te koppelen aan informatie over effecten van statelijke en internationale wetgeving, beleid en discours. Dit hoofdstuk onderschrijft het belang van dergelijke literatuur en beoogt eraan bij te dragen.

Hoofdstuk 4 geeft een gedetailleerde analyse van de strijd om rechten op grond tussen verscheidene lokale actoren in het dorp Besease. Deze rechten omvatten achtereenvolgens het recht grond te verkopen, de overdrachtspapieren te tekenen, en de opbrengsten van de transactie te ontvangen. Aangezien in dit dorp vier traditionele leiders ieder een deel van de dorpsgrond besturen, vormt Besease vier casussen in één. Deze casussen maken duidelijk dat ook in Besease de traditionele elite disproportioneel profiteert van de verkoop van grond voor woningbouw ten koste van kleine boeren en kopers. Zij laten zien dat traditionele leiders niet alleen een sterke positie hebben doordat het gewoonterechtelijke systeem hen aanwijst als bestuurders van de grond, maar ook doordat zij de bestuurlijke instrumenten hebben om, vaak met instemming van het ambtenarenapparaat op district- en regioniveau, bestemmingsplannen op te stellen en dorpsgrond te verdelen in percelen voor woningbouw. 
Dit hoofdstuk trekt het nut en de bruikbaarheid in twijfel van de huidige trend in de literatuur om alle lokale veranderingen in rechten op grond te beschrijven als het resultaat van 'onderhandelingen' (negotiations). De data van Besease laten immers zien dat het geregeld voorkomt dat één van de partijen zijn macht gebruikt om de rechten van de ander volledig te ontkennen of herdefiniëren. Te grote nadruk op de onderhandelbaarheid van lokale rechten op grond leidt tot een overschatting van de manoeuvreerruimte van zwakkere partijen. Het beeld van een relatief open, onderhandelbaar en aanpasbaar systeem van gewoonterechtelijk grondbeheer versluiert processen van uitsluiting en klassevorming en leidt er vaak toe dat men vergeet te vragen wie er wint en wie er verliest bij veranderingen. Bij de beoordeling van gewoonterechtelijk grondbeheer en de beleidsbeslissing dergelijke systemen te erkennen of te versterken moeten lokale stratificatie en machtsverschillen in het oog gehouden worden. De positie van kwetsbare groepen verbetert niet per definitie door maatregelen die gewoonterechtelijke instituten en lokaal beheer van toegang tot grond versterken. Wanneer zij niet vergezeld gaan van maatregelen die de macht van lokale bestuurders aan banden leggen, kunnen zij de bestaande lokale ongelijkheid juist versterken.

Hoofdstuk 5 stelt de vraag aan de orde wat voor gevolgen het grondbeheer van de traditionele leiders heeft op lokale percepties van hun positie en taken en van het instituut van traditioneel leiderschap. Dit is een relevante vraag gezien de eerder genoemde hernieuwde interesse van Afrikaanse overheden, internationale instellingen en donoren in traditioneel leiderschap. Deze hernieuwde belangstelling wordt door sommigen verklaard vanuit het functioneren of disfunctioneren van de postkoloniale staten en het ontstaan van nieuwe publieke ruimte ten gevolge van meerpartijendemocratie, decentralisatie en liberaliseringsbeleid. Anderen verwijzen naar de functies die traditionele leiders (kunnen) verrichten in hun gemeenschappen. Beide verklaringen besteden nauwelijks aandacht aan hoe lokale mensen denken over hun traditionele leiders, hun bestuurlijke prestaties en het instituut van traditioneel leiderschap. Dat is niet verwonderlijk, aangezien er hierover zeer weinig data bekend zijn. Empirisch onderzoek naar percepties van dorpelingen kan echter bijdragen aan een genuanceerder beeld van de lokale rol van en waardering voor traditionele leiders, en derhalve van belang zijn voor nationale en internationale beleidsmakers.

In dit hoofdstuk worden daarom de percepties beschreven van dorpelingen uit twaalf dorpen in peri-urbaan Kumasi, met betrekking tot de door hen genoemde belangrijkste functies van de traditionele leiders. Deze functies zijn in 4 groepen onderverdeeld: I) grondbeheer; 2) lokale ontwikkelingsprojecten; 3) rechtspraak en ordehandhaving; en 4) traditionele religie. De surveydata laten zien dat de alom aanwezige 
steun voor het instituut van traditioneel leiderschap niet noodzakelijk voortvloeit uit of zelfs maar samengaat met tevredenheid over de bestuurlijke prestaties van traditionele leiders. De steun lijkt eerder te moeten worden verklaard vanuit het domein van de cultuur en identiteit. Mensen kunnen dus tegelijkertijd het instituut steunen, bijvoorbeeld omdat zij het noodzakelijk vinden dat het dorp bij traditionele en culturele ceremoniën wordt vertegenwoordigd door een traditionele leider, en uitermate kritisch zijn over de verrichtingen van bepaalde leiders of de uitvoer van bepaalde taken. Wanneer overheden besluiten tot een meer formele erkenning van traditioneel leiderschap, zou dat dus niet moeten samengaan met een kritiekloze acceptatie van de manier waarop traditionele leiders al hun taken uitvoeren. Beleidsmakers moeten rekening houden met het daadwerkelijk functioneren van traditionele leiders - en de lokale percepties daarvan - en op basis daarvan besluiten bepaalde functies geheel aan de lokale leiders over te laten, maar andere te controleren of aan banden te leggen.

De rol van statelijke rechtbanken als toetsingsinstantie van de rechtmatigheid van gewoonterechtelijk grondbeheer vormt het onderwerp van hoofdstuk 6. Uit de Ghanese jurisprudentie komt een beeld naar voren van bescherming van de gebruiksrechten van de kleine inheemse boer tegen pogingen van traditionele leiders om zich gemeenschapsgrond toe te eigenen en te verkopen voor huisvestingsdoeleinden. In de jurisprudentie is bovendien bepaald dat traditionele leiders verantwoording verschuldigd zijn voor de besteding van opbrengsten uit gemeenschapsgrond. Er is wel een trend waarneembaar in de jurisprudentie om traditionele leiders meer bestuurlijke bevoegdheden toe te kennen, maar die kan niet zo worden geïnterpreteerd dat zij gemeenschapsgrond geheel naar eigen wens kunnen beheren zonder rekening te houden met gemeenschapsbelangen en compensatie voor boeren.

De praktijk van grondbeheer in peri-urbaan Kumasi wijkt beduidend af van de rechterlijke interpretatie van gewoonterecht ten aanzien van grondbeheer. Dit wijst erop dat het effect van rechterlijke uitspraken op de dagelijkse realiteit beperkt is. Hoewel er enorme aantallen grondzaken worden behandeld in de rechtbanken, gaan slechts enkele daarvan over bovenstaande problematiek. De meeste geschillen over toeeigening, omzetting en verkoop van gemeenschapsgrond door traditionele leiders bereiken de rechtbanken niet, hetzij vanwege gebrekkige toegang tot het rechtssysteem of ontbreken van interesse bij de partijen, hetzij omdat deze conflicten deel uitmaken van conflicten over "chieftaincy affairs" waarin de statelijke rechtbanken geen jurisdictie hebben. Daarnaast lijken rechterlijke uitspraken vanwege een aantal factoren weinig effect te hebben op grondconflicten buiten de specifieke zaken waarin de uitspraken zijn gedaan. Ten eerste lijkt de kennis die dorpelingen hebben van rechterlijke uitspraken minimaal te zijn in 
peri-urbaan Kumasi. Ten tweede hebben we gezien dat traditionele leiders worden beschouwd als autoriteiten op het gebied van gewoonterecht en hoeders van de communale grond en zich daardoor in een uitermate geschikte positie bevinden om gewoonterecht in hun voordeel te interpreteren. Wanneer we hierbij de eerder genoemde erosie van lokale controlemechanismen en het gebrek aan statelijke controle op traditionele leiders optellen, verrast het niet dat zij zich weinig gelegen laten liggen aan de rechterlijke uitspraken die de rechten van de kleine boer beschermen.

De besproken hoofdstukken laten zien dat er verschillende versies van gewoonterecht onderscheiden moeten worden. In de dorpen leven uiteenlopende ideeën over wat het lokale gewoonterecht is. Deze ideeen worden niet alleen verwoord in normatieve uitspraken, maar ook daadwerkelijk in praktijk gebracht. Naast deze verschillende versies van lokaal gewoonterecht - of verschillende beweringen wat het lokale gewoonterecht is - creëren rechters hun eigen versie van gewoonterecht, ook wel 'rechters gewoonterecht' genoemd. Hoewel van wetgevers, beleidsmakers en openbaar bestuurders verwacht mag worden dat zij deze rechtersversie volgen, blijken zij in de praktijk vaak hun eigen interpretaties van en ideeën over gewoonterecht te hebben. Het zijn deze ideeën die zij meestal als leidraad nemen voor bestuurlijke beslissingen en nieuwe wetgeving of beleid.

De eindconclusie van dit boek, hoofdstuk 7, besteedt aandacht aan de verschillende versies van gewoonterecht. Het bestudeert wat lokaal gewoonterecht is, hoe het evolueert, hoe het bestudeerd kan worden, en hoe een rechter, beleidsmaker, of wetgever het kan toepassen of in tekst neerleggen. Dit boek laat zien dat er momenteel in peri-urbaan Kumasi geen consensus bestaat over de gewoonterechtelijke regels met betrekking tot de omzetting en verkoop van landbouwgrond voor huisvesting. De praktijk laat evenveel variatie zien als de normatieve uitspraken die er over het onderwerp worden gedaan. En aangezien conflicten zelden worden behandeld, laat staan naar tevredenheid van partijen opgelost, door lokale geschillenbeslechting, kan ook daar de geldende norm niet uit afgeleid worden. Het veld kenmerkt zich door eenzijdige besluitvorming, strijd en onderhandelingen, waarvan de uitkomsten slechts zeer ten dele worden bepaald door algemeen aanvaarde normen en regels van gewoonterecht. Hoewel onderzoekers wellicht tevreden zullen zijn met een beschrijving van de veranderlijkheid en manipuleerbaarheid van gewoonterechtelijke normen, wordt van rechters, wetgevers en beleidsmakers met de opdracht gewoonterecht toe te passen, verwacht dat zij uit de verschillende praktijken de meest geëigende selecteren. Dit hoofdstuk laat zien dat deze keuze niet geheel vrij gebaseerd mag worden op politieke overwegingen of op de persoonlijke voorkeur van de ambtenaar. Zij moet passen binnen het 
bredere normatieve kader van het gewoonterecht en kent bepaalde normatieve toetsstenen in de vorm van usus - herhaling van feiten - en opinio necessitatis - het algemeen gedeelde gevoel dat men verplicht is de regel na te leven.

De theoretische implicaties van dit inzicht reiken verder dan Ghana alleen. Een exclusieve focus op de lokale werkelijkheid en lokale praktijken van machtige actoren als leidraad om regels van gewoonterecht te bepalen brengt het risico met zich mee dat 'wat er ook lokaal gebeurt' geaccepteerd wordt als gewoonterecht, zonder rekening te houden met de samenhang met het bredere kader van gewoonterecht. Een te grote nadruk op de onderhandelbaarheid van gewoonterecht kan hetzelfde effect hebben, namelijk een de facto erkenning van de uitkomsten van lokale machtsstrijd. Hoewel gewoonterecht tot op een bepaalde hoogte flexibel, onderhandelbaar en relationeel is, stelt dit boek dat het wel ook een normatieve inhoud heeft die het mogelijk maakt om afwijkingen van de norm te herkennen, zelfs wanneer die met verwijzing naar veranderende omstandigheden en normen worden gelegitimeerd.

Hoofdstuk 7 sluit ten slotte af met een vooruitblik. Ondanks alle geschetste problemen op het gebied van traditioneel grondbeheer erkent dit onderzoek gewoonterecht en traditioneel leiderschap als politieke en sociale realiteiten in hedendaags Ghana en concludeert dat de problemen grotendeels binnen deze kaders opgelost moeten worden. Zoals gezegd betekent dat niet dat de overheid klakkeloos alle handelingen en beslissingen van traditionele leiders moet accepteren. Het boek besluit dan ook met een aantal aanbevelingen over de rol die het statelijk rechtsbestel kan spelen in de vergroting van zekerheid op grond van kleine boeren in peri-urbaan Kumasi en andere delen van Ghana. 


\section{Curriculum vitae}

Janine Ubink was born in Apeldoorn, on June 2 1976. After having completed secondary education (Stedelijk Gymnasium in Breda) in I994, and having obtained her foundation course in biomedical sciences in I995, she switched to the faculty of law. In the year 2000 she obtained her masters in public international law at Leiden University. During her studies she spent several months in Sri Lanka, Uganda and Ghana. She also worked at 'Vluchtelingenwerk', a volunteer organization for legal assistance to refugees, and she worked for two years as a student assistant at the Van Vollenhoven Institute at Leiden University, mainly on research cooperation between the Netherlands and Indonesia. In 200I she was appointed at the Van Vollenhoven Institute as PhD researcher to carry out the research on which this thesis is based. Apart from her work as a PhD researcher, she has organized an international seminar entitled 'Contesting land and custom in Ghana: state, chief and the citizen' in Accra in 2006. She has also taught courses in Law and Governance in Africa, Legal Systems Worldwide, Law, Governance and Development, Law and Culture, and - in Suriname - Governance and the Legal Framework. In addition, she is involved in a research project studying land tenure legalization programs in nine countries in Africa, Latin America, and Asia. As a staff member of the institute Janine Ubink coordinates the Africa activities. Presently, she works as an assistant professor at the law faculty of Leiden University and is a member of the executive body of the Commission on Legal pluralism. 
